\title{
The hydrological viability of Te Harakiki wetland, Waikanae
}

Rebecca Anne Law

A thesis submitted to Victoria University of Wellington in partial fulfilment of the requirements for the degree of Master of Science in Physical Geography.

School of Geography, Environmental and Earth Sciences,

Victoria University of Wellington

March 2008 


\section{Abstract:}

Wetlands are unique natural resources that play an important role in the hydrological cycle. There is a dynamic link between wetland hydrology and inputs from both surface and groundwater resources. Shallow groundwater abstraction near the Te Harakiki wetland at Waikanae has the potential to impact on the wetland's hydrosystem. To assess the likelihood of this occurring, a detailed analysis of recent changes, the hydrological regime, and the water balance of the Te Harakiki Wetland system was undertaken.

The hydrological regime of the wetland system was assessed by various monitoring sites established around Te Harakiki to measure rainfall, soil moisture, surface and groundwater levels. Analysis of (decadal) historical aerial photographs allowed changes in spatial extent of the open water habitat (lagoon) and the urban area of Waikanae Beach. Comparisons were made between wetland extent, population increase and urban area expansion. These data, together with a simple water balance, and historical climatic records, were used to explain the drastic decrease in wetland extent.

Climatic factors and groundwater are the major driving forces behind the wetland's hydrologic regime. The surface water outflow from the system is greater than the surface water inflow, but this may be affected by the tides. The surface and groundwater systems in the area are closely linked. They have similar responses to rainfall events. Groundwater abstraction in the area appears to have minimal impact on the water level within the wetland. The exact nature and extent of abstraction around the wetland is unknown.

The reduction in flood pulsing as a result of channel modification, and the fragmentation of the area for the construction of the oxidation ponds are the likely explanation. The current restoration efforts in regard to controlling pest species and excluding stock from the wetland have halted the decline in wetland area. The future of the Te Harakiki wetland system is now more positive. 


\section{Acknowledgements:}

As in any piece of research there are many people who helped along the way to make this (and my life) a far easier and smoother process. My thanks to you all.

Firstly and fore mostly I have to thank my supervisor, Jack McConchie for all his words of wisdom, pushes in the right direction, help with my fieldwork and editing skills. This never would have come together without him.

Thanks to all my mates and family for putting up with me, keeping sane and allowing me to have some form of social life, Sam and Jem you are the best. Thanks to Kelsey for looking out for my horse when I was too busy.

Thanks to all my office mates over the last 2 years, Helli, Rod, Des, Anna and Sam, it's been fantastic to have people talk to and bounce ideas off and I wish you guys all the best.

Thanks have to go out to Michael Killick for ongoing support with the field work side of my project, and Mark Henderson for his neat wiring job on all the TDR, it sure made it easier to install. Thanks to Andrew Rae for his help with the G.I.S side of things and letting me share his office space for a few months. Special mention to David Kennedy and Gillian Ruthven for stepping in, editing chapters and helping me with all the finishing touches, I never would have been near to reaching my deadline otherwise.

Thanks to Jonathan Smith and family for their ongoing support of my project and allowing me access to their land.

Thanks to Blair Coburn and all the golfers at the Waikanae Golf Course for allowing me access through the course, letting me use the golf carts and for not hitting me with golf balls.

Big thanks to Greater Wellington for their financial support, and especially Nick Boyens, Tim Park and Wendy Purdon who all took the time out to talk to me, share data, photos and advice. It was all greatly appreciated.

Thanks to Kapiti District Council who supplied me with some of the initial information on the area, aerial photographs and access to my site. Special thanks to Matthew Brown who took time out to help me get the information I needed.

Huge thanks to my Mum for proof reading all my chapters - not sure she quite knew what she was agreeing to when she said yes, but I really appreciated it.

And finally a big thank you to Leighton who has waited patiently for me to finish, your support through this has been appreciated, believe me. I Love you. 


\section{Table of Contents}

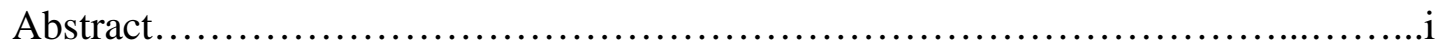

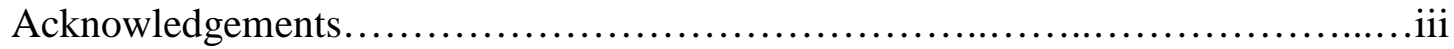

Table of Contents...............................................................

List of Figures........................................................

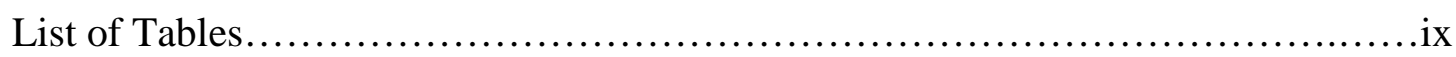

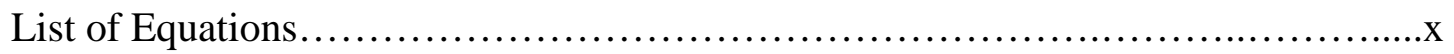

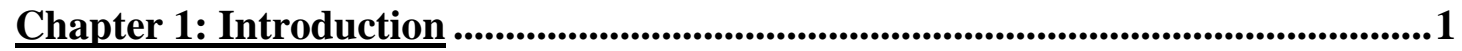

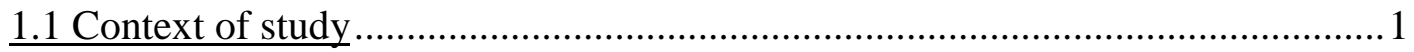

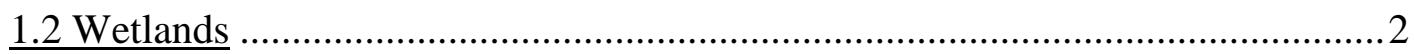

1.3 The Issue and Research Aims ...................................................................... 5

Chapter 2: Conceptual Background .............................................................................7

2.1 Introduction: The Importance of Wetlands ................................................... 7

2.1.1 Water Quality improvement ................................................................ 11

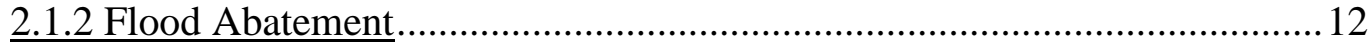

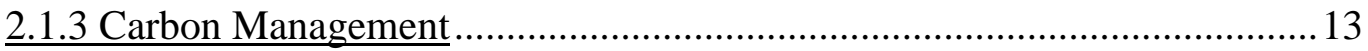

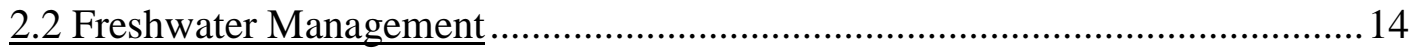

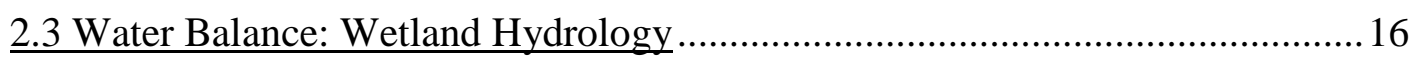

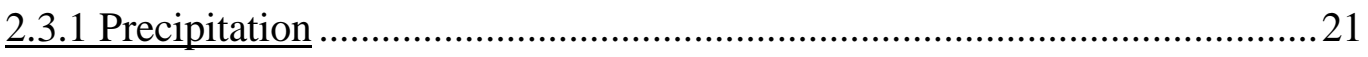

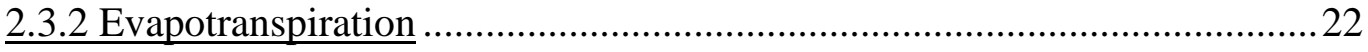

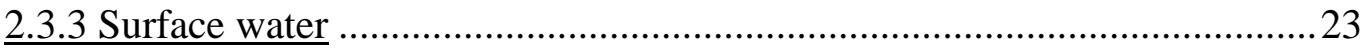

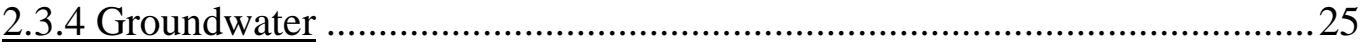

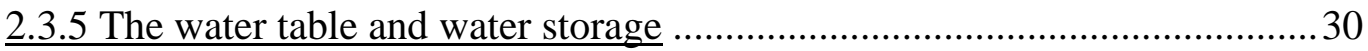

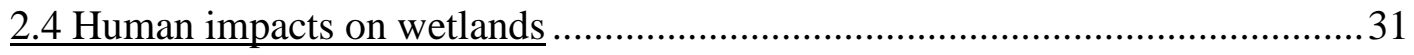

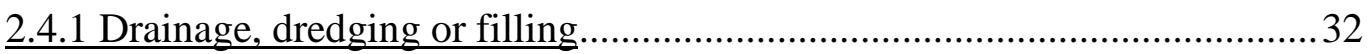

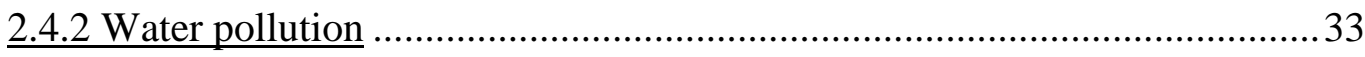

2.4.3 Modification of the hydrological regime …................................................. 34

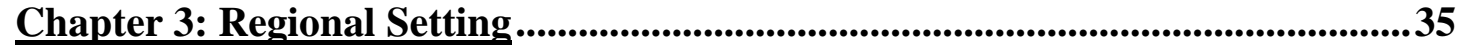

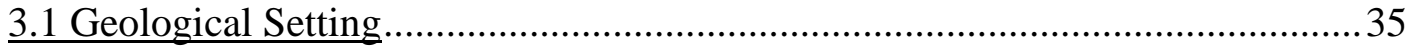

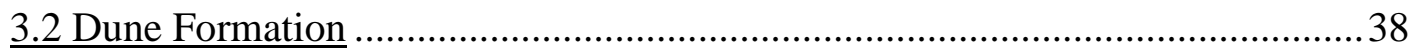

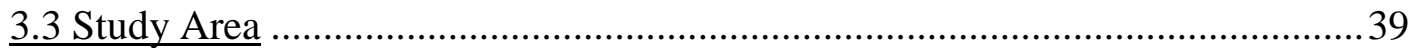


Chapter 4: Methodology.......................................................................................................44

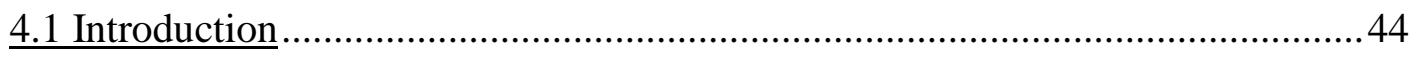

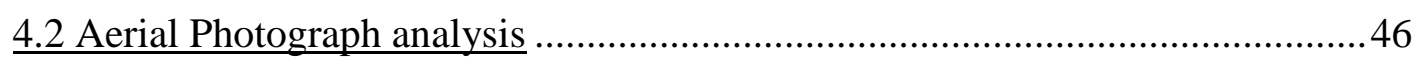

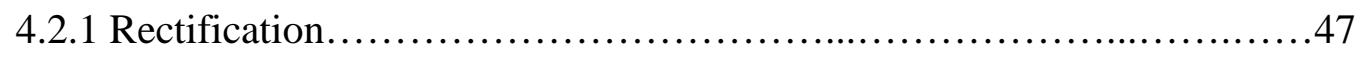

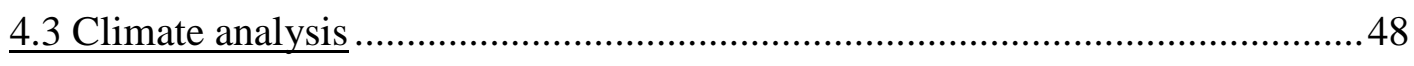

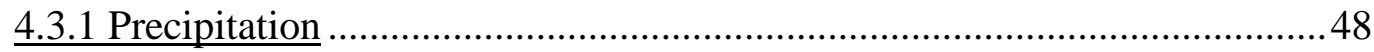

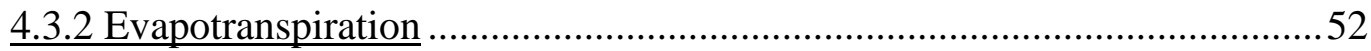

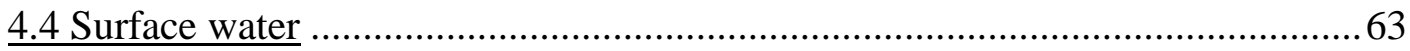

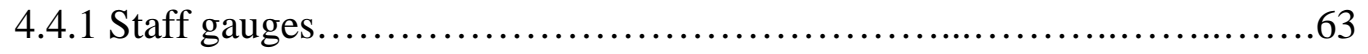

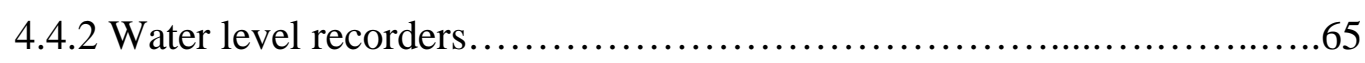

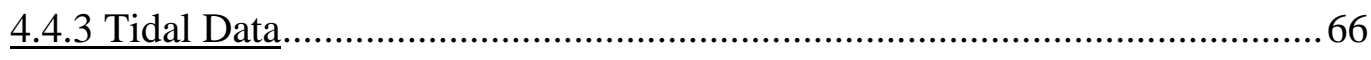

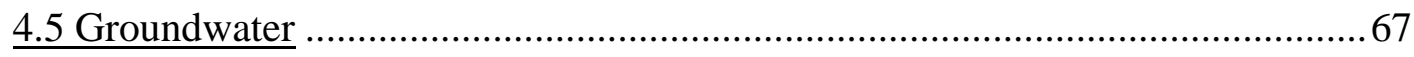

4.5.1 Groundwater flow direction ................................................................. 70

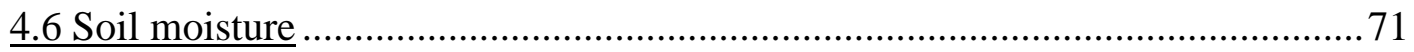

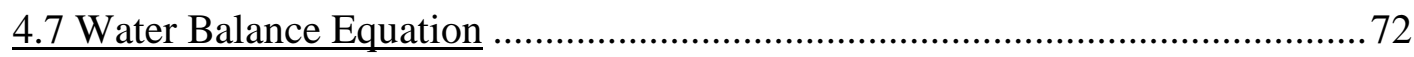

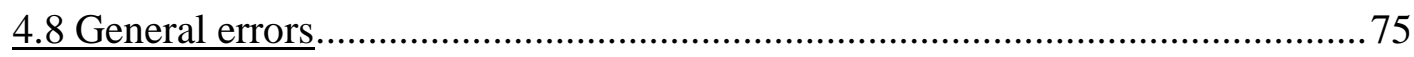

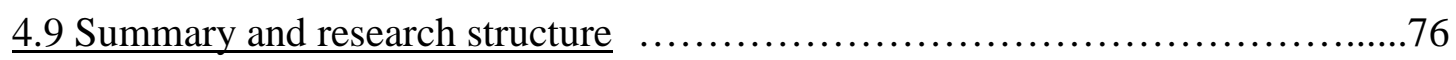

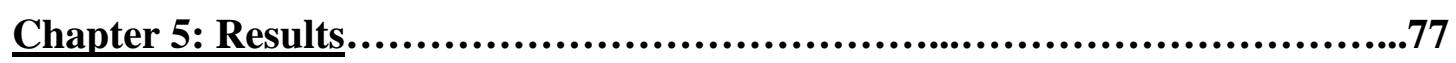

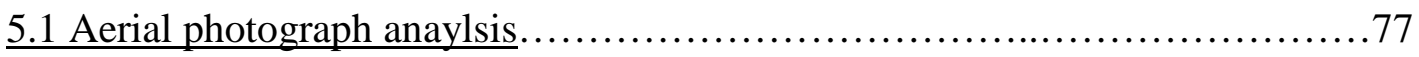

5.1.1 Wetland (lagoon) extent ..............................................77

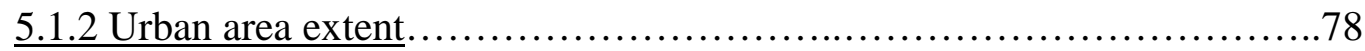

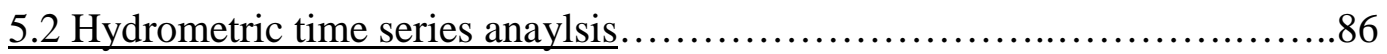

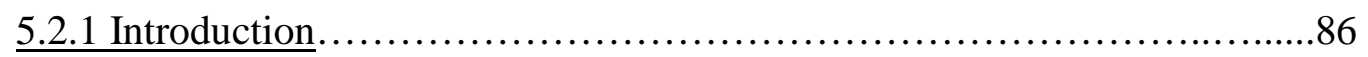

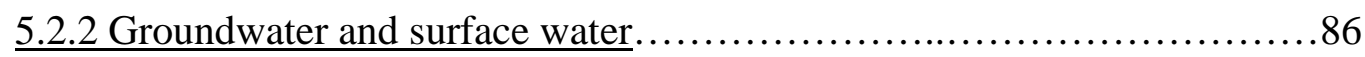

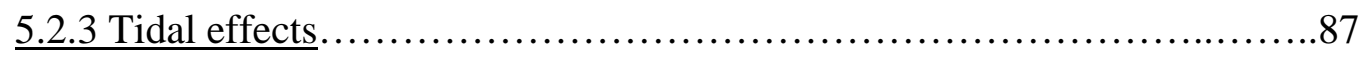

5.2.4 Grondwater flow.........................................................

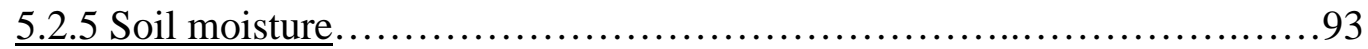

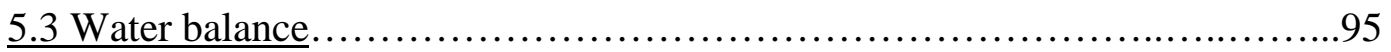

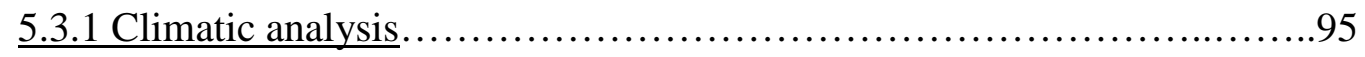

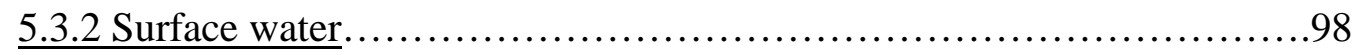

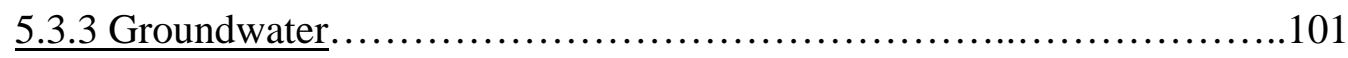

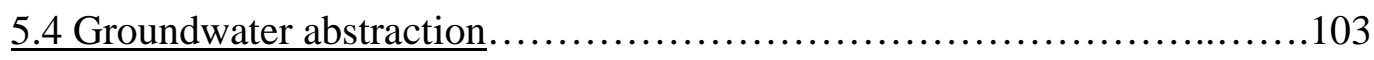

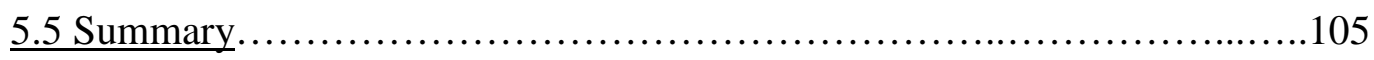

Chapter6: Disscussion.................................................................106 


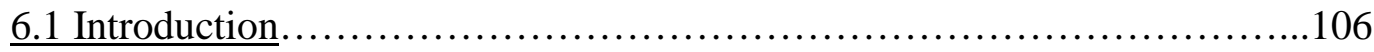

6.2 Hydrological regime and water balance.................................106

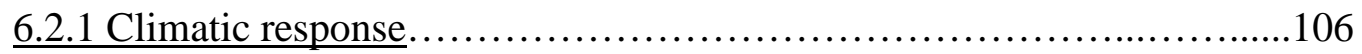

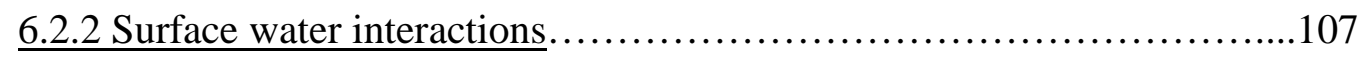

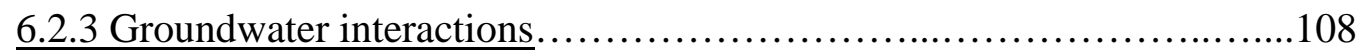

6.3 Implpications for the management of Te Harakiki..........................109

6.3.1 Groundwater abstractions........................................109

6.3.2 The long term viability of the wetland ...............................110

Chapter 7: Summary and recommendations..................................113

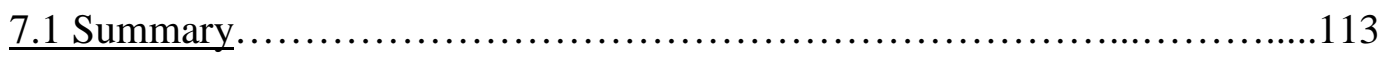

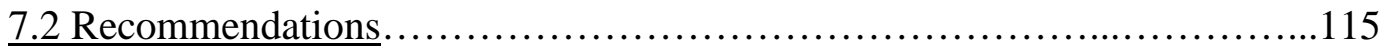

References........................................................................117

\section{Appendices}

Appendix 1

Appendix 2

Appendix 3

Appendix 4 


\section{List of Figures}

Figure 1.1 Location of known shallow groundwater bores........................ 3

Figure 1.2 Property densities on the Kapiti Coast...............................4

Figure 1.3 Modelled cumulative irrigation abstraction from shallow sand aquifers on the Kapiti Coast............................................................. 5

Figure 2.1 General functioning relationships within a wetland ecosystem.............7

Figure 2.2 Main components of wetlands by definition; hydrology, physiochemical environment and biota....

Figure 2.3 The components of a water balance for a wetland system...............18

Figure 2.4 Schematic diagram of water inputs and outputs from a wetland system...20

Figure 2.5 Formation of a cone of depression around a pumped well............... 28

Figure 2.6 Major anthropogenic impacts on a wetland system as a result of changes in water, nutrients and disturbance levels .............................32

Figure 3.1 Distribution of main geologic deposits on the Kapiti Coast...............36

Figure 3.2 North - South geological cross section through the Waikanae

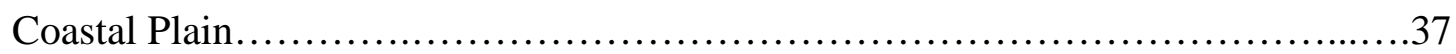

Figure 3.3 Generalised hydrologic landscape found in hummocky dune terrain.......40

Figure 3.4 Aerial photograph of Te Harakiki showing the location of the wetland within the coastal dune system......................................41

Figure 4.1 The location and distribution of field sites at Te Harakiki.................45

Figure 4.2 Rain gauge with tipping bucket mechanism........................49

Figure 4.3 Distribution of monitoring equipment at site $2 \ldots \ldots \ldots \ldots \ldots \ldots \ldots \ldots . \ldots . \ldots \ldots$

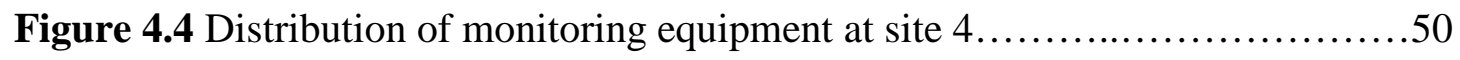

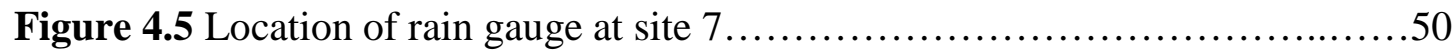

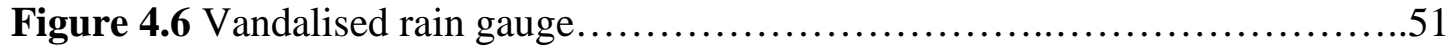

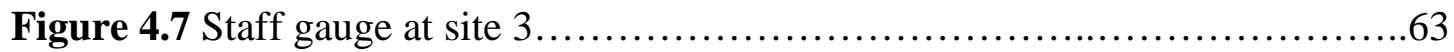

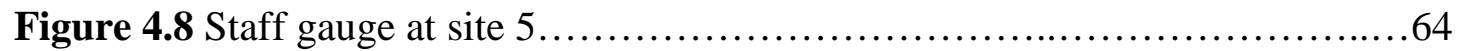

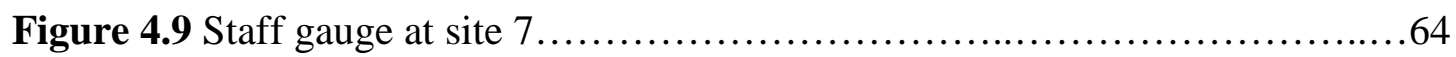

Figure 4.10 MiniTROLL set up on a staff gauge...............................66

Figure 4.11 Tidal calculation table.....................................67

Figure 4.12 Distribution of monitoring equipment at site $1 \ldots \ldots \ldots \ldots \ldots \ldots \ldots \ldots \ldots \ldots$

Figure 4.13 Location of groundwater monitoring equipment at site $6 \ldots \ldots \ldots \ldots \ldots 70$ 
Figure 4.14 a, b, c, TDR probes installed in pits at sites 1,2 and $4 \ldots \ldots \ldots \ldots \ldots \ldots 72$

Figure 5.1 a, b, c, d, e Changes in Wetland (lagoon) extent, 1966 - 2002.............80

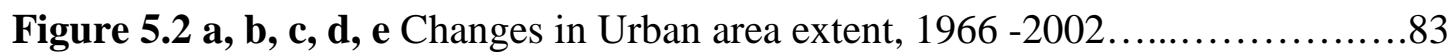

Figure 5.3 Response of surface water and groundwater to a rainfall event............86

Figure 5.4 Ngarara Stream sties 3 and 7, illustrating the tidal influence at site $7 \ldots \ldots . .88$

Figure 5.5 Peaks in surface water level at site 7 as a result of high tide..............89

Figure 5.6 Groundwater level and flow direction in shallow unconfined dunesand,

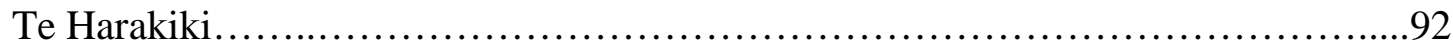

Figure 5.7 Response of groundwater and soil moisture at 40 and $80 \mathrm{~cm}$ to a rainfall

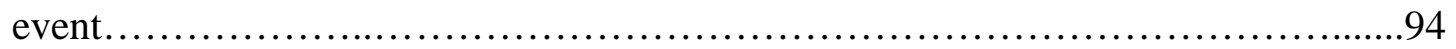

Figure 5.8 Progression of the wetting front through the soil profile..................94

Figure 5.9 Mean annual rainfall for Paraparaumu 1966 - 1978 ....................96

Figure 5.10 Mean annual rainfall for Paraparaumu 1996 - 2006 ..................97

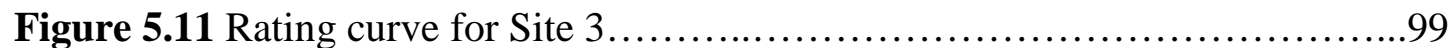

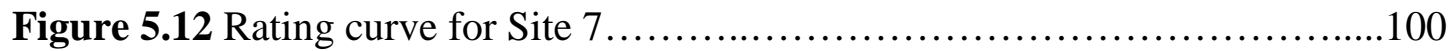

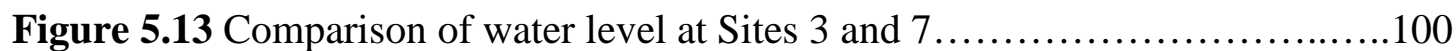

Figure 5.14 Modelled water levels at Te Harakiki under different abstraction scenarios. 104 


\section{List of Tables}

Table 2.1 Global wetland area by region..........................................

Table 2.2 Wetland area from selected soil groups...............................

Table 2.3 Wetland water inflows and outflows...............................20

Table 2.4 Soil descriptions and soil moisture capacity values for the Kapiti Coast...29

Table 4.1 Aerial photograph details.........................................48

Table 5.1 Changes in wetland (lagoon) extent 1966 - 2002.....................77

Table 5.2 Changes in urban area extent 1966 - 2002 .............................78

Table 5.3 Population data for Waikanae Beach 1966 - 2006.......................79

Table 5.4 Tidal times and heights (August 25 - September 4 2007).................................................................. 90

Table 5.5 Cumulative mean water balance, Te Harakiki........................95

Table 5.6 Monthly, daily average components required to calculate

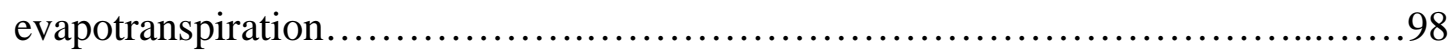

Table 5.7 Ngarara Stream flow measurements (monthly mean)....................99

Table 5.8 Surface water outflow............................................... 101

Table 5.9 Hydraulic conductivity of piezometers at Te Harakiki...................102

Table 5.10 Groundwater level monitoring ...................................102 


\section{List of Equations}

Equation 2.1 Water balance equation one................................

Equation 2.2 Water balance equation two............................... 79

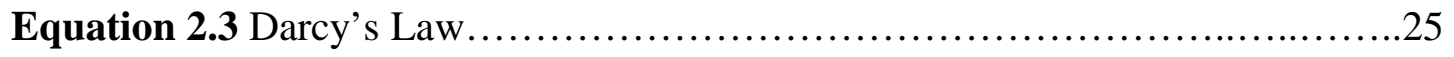

Equation 2.4 Darcy's Law re-written.................................... 74

Equation 4.1 Food and Agriculture Organisation Penman - Monteith reference

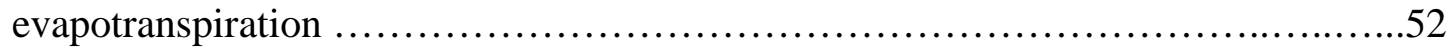

Equation 4.2 Atmospheric pressure ........................................53

Equation 4.3 Psychrometric constant .......................................5

Equation 4.4 Mean air temperature..........................................54

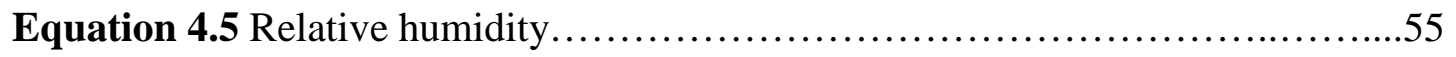

Equation 4.6 Saturation vapour pressure at a given air temperature ...............55

Equation 4.7 Mean saturation vapour pressure................................56

Equation 4.8 Slope of the saturation vapour pressure curve ......................56

Equation 4.9 Actual vapour pressure from relative humidity data..................56

Equation 4.10 Vapour pressure deficit.......................................56

Equation 4.11 Extraterrestrial radiation......................................57

Equation 4.12 Latitude in radians........................................58

Equation 4.13 Inverse relative distance Earth - sun...........................58

Equation 4.14 Solar declination..............................................58

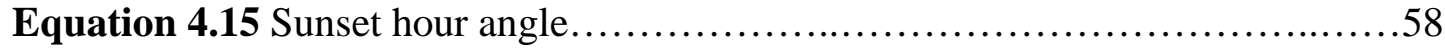

Equation 4.16 Daylight hours..............................................58

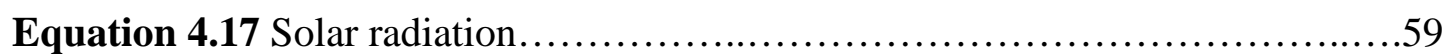

Equation 4.18 Clear sky solar radiation........................................59

Equation 4.19 Clear sky solar radiation....................................59

Equation 4.20 Relative shortwave radiation.................................60

Equation 4.21 Net shortwave radiation.....................................6

Equation 4.22 Net longwave radiation.....................................6

Equation 4.23 Net radiation..................................................61

Equation 4.24 Soil heat flux..............................................62

Equation 4.25 Wind speed..............................................62

Equation 4.26 Surface water outflow........................................ 74

Equation 4.27 Hydraulic gradient............................................ 75

Equation 4.28 Hydraulic head............................................. 75 


\section{Chapter 1: Introduction}

\section{1: Context of study}

Freshwater is a fundamental natural resource. It is a requirement for the survival of many forms of life. Freshwater is a key element in terms of environmental values. It provides ecosystem services such as waste treatment and climate regulation; it underpins economic prosperity, through power generation and industrial processes; and health and cultural identity (Department of the Prime Minister and Cabinet (DPMC) 2003). New Zealand generally has plentiful water supplies from abundant rainfall. The national average annual rainfall is approximately $3380 \mathrm{~mm}$. However, rainfall is not spread evenly either geographically or seasonally. Rainfall ranges from $6240 \mathrm{~mm} / \mathrm{yr}$ in Milford Sound to 340mm/yr in parts of Central Otago (Woods and Howard-Williams, 2004, Waugh, 1992). The uneven distribution of rainfall across the country, and throughout the year, means that a reliable source of clean water has become a significant issue in some areas. Waikanae, on the Kapiti Coast in the Southern North Island is one such location. Until recently the community relied solely on the Waikanae River for potable water. Increased pressure has been placed on this water source as a result of population growth and improved standards of living.

With extraction from the Waikanae River now at its limit the Kapiti Coast District Council (KCDC) has had to look elsewhere for an alternative, reliable water source. Attention is now being directed at developing and utilising the local groundwater resource. Groundwater is less susceptible than surface water to variations in supply, quality and to pollution (Fenwick et al, 2004). Groundwater is stored in aquifers, geological formations that are porous enough to hold significant amounts of water and permeable enough to release the water at a rate to be useful (Fenwick et al, 2004).

Groundwater is an important part of the hydrological cycle: sustaining rivers, lakes and wetlands. Once groundwater has been depleted or polluted it can not be replenished readily and this may pose a risk to the sustainability of ecosystems, particularly wetlands. The affects of any groundwater abstraction on wetlands, therefore needs to be considered when considering the utilisation of this resource. 
Only through a full understanding of the hydrological cycle, and all its various interactions can rivers, streams, lakes, groundwater and wetlands be managed in "an ecologically sustainable manner" (Jones and Gyopari, 2005, Fenemor, 1992 ).

\section{2: Wetlands}

Wetlands are a key natural resource and are the most species diverse of freshwater habitats (Sorrell et al. 2004). They occur where the topography, climate, soil and drainage system of an area allow water to collect long enough to promote the formation of hydric soils, hydrotrophic vegetation and biological activities adapted to wet conditions (Jones and Gyopari, 2005, Price and Waddington, 2000, Winter, 2000, Hollis and Thompson, 1998).

The variable nature of wetland environments makes it difficult to assign an all encompassing definition. Wetlands exist as a transitional landform or ecotone between terrestrial and aquatic habitats. Their transitional nature, in both time and space makes classification difficult (Hollis and Thompson, 1998). The Resource Management Act (1991) defines wetlands as "permanently or intermittently wet areas, shallow water and land margins that support a natural ecosystem of plants and animals that are adapted to wet conditions" (Campbell and Jackson, 2004).

Wetland systems can develop in a wide variety of locations in the landscape from estuarine to alpine areas (Campbell and Jackson, 2004). The classification of wetland type is based on several levels; the hydrological system within which the wetland occurs (hydrosystem), nutrient (trophic) status, substrate (soil) type, landform and vegetation type (Campbell and Jackson, 2004).

A wetland system supports a diverse assemblage of plants and animals that have adapted to living in wet conditions (Greater Wellington Regional Council (GW), 2005). These ecosystems, being reliant on the availability of water are vulnerable to any change in their hydrological regime. Such changes might include variations in water level, and the frequency and duration of inundation and drying cycles. While 
natural variations do occur, human activities such as drainage, the discharge of storm water, flood protection works and over-extraction from surface or groundwater systems within the wetland catchment can cause significant changes to the hydrological regime. These changes may affect the viability of the wetland itself (GW, 2005). It is therefore important to understand the hydrology of a wetland system so as to be able to assess the potential impacts of any changes within the catchment.

The Kapiti area has undergone a period of rapid population growth, placing increased pressure on the area's water resources. The Waikanae River is no longer able to provide the region with a reliable, sustainable supply of water. Because water restrictions are often placed on residents, a growing number of properties have shallow bores for irrigation water (Figure 1.1). Under the Regional Plan the drilling of shallow $(<6 \mathrm{~m})$ bores was a permitted activity until 2000 and no resource consent was required. Because of this there is usually little or no documentation as to the location, and volume of abstraction from these bores. This makes it impossible to determine how much water is abstracted from the area's shallow aquifers.

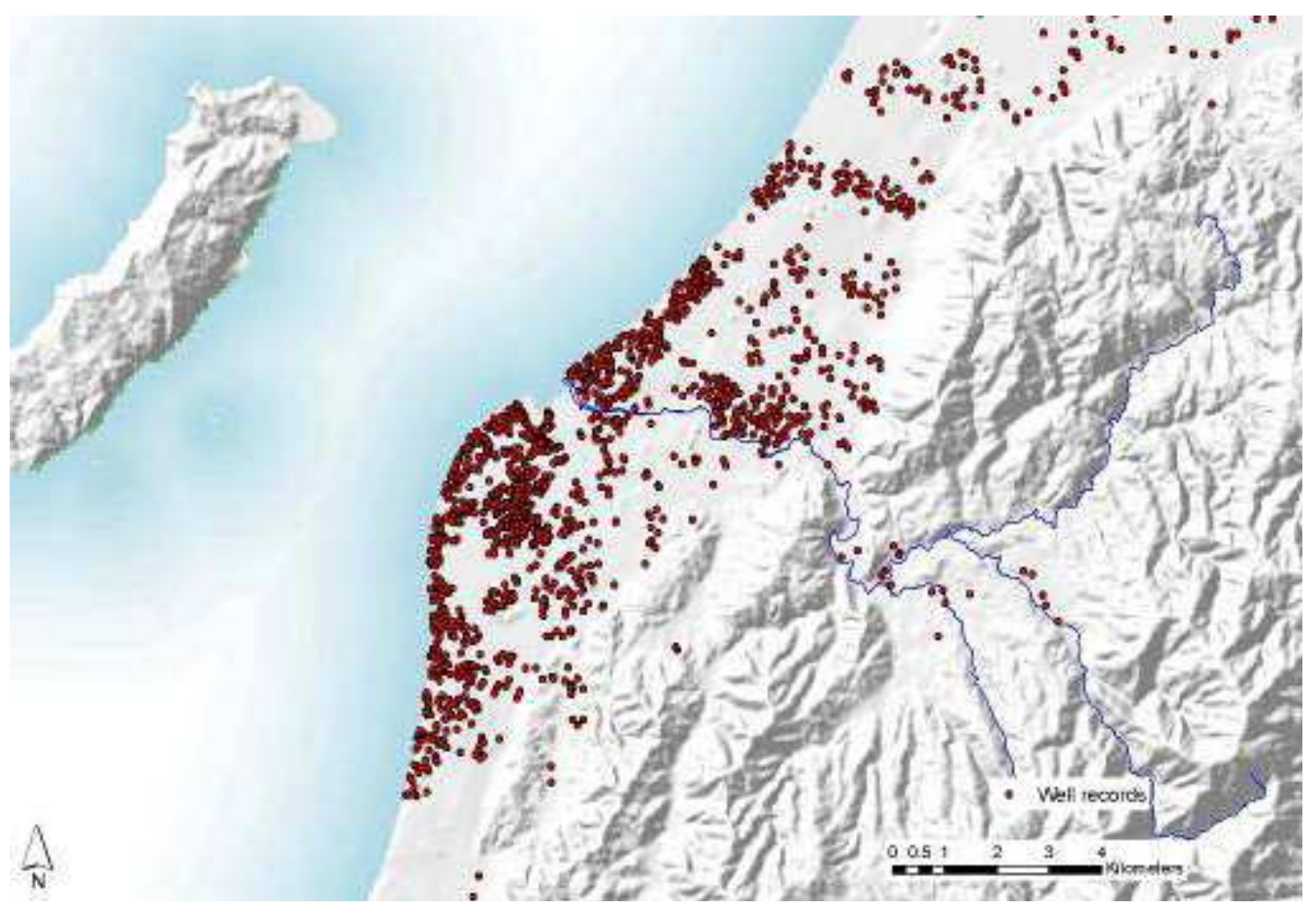

Figure 1.1: Location of known shallow groundwater bores in Raumati, Paraparaumu, Waikanae and Pekapeka. Source: Jones and Baker, 2005.

Jones and Gyopari (2005) estimated the sustainable yield from shallow groundwater on the Kapiti Coast. As part of that study they considered the impact of shallow 
garden irrigation wells on both the shallow groundwater and the surface water ecosystems. It was assumed that $50 \%$ of properties have shallow bores giving a total of approximately 3000 . When considering the more established urban areas on the coast, this is probably a conservative assumption. To estimate the total volume of water abstracted, the residential property density was calculated. This was done by placing a $250 \mathrm{~m}$ square grid over the area and counting the number of properties per grid using a GIS. The grid squares, then were assigned a property density class. (Figure 1.2)

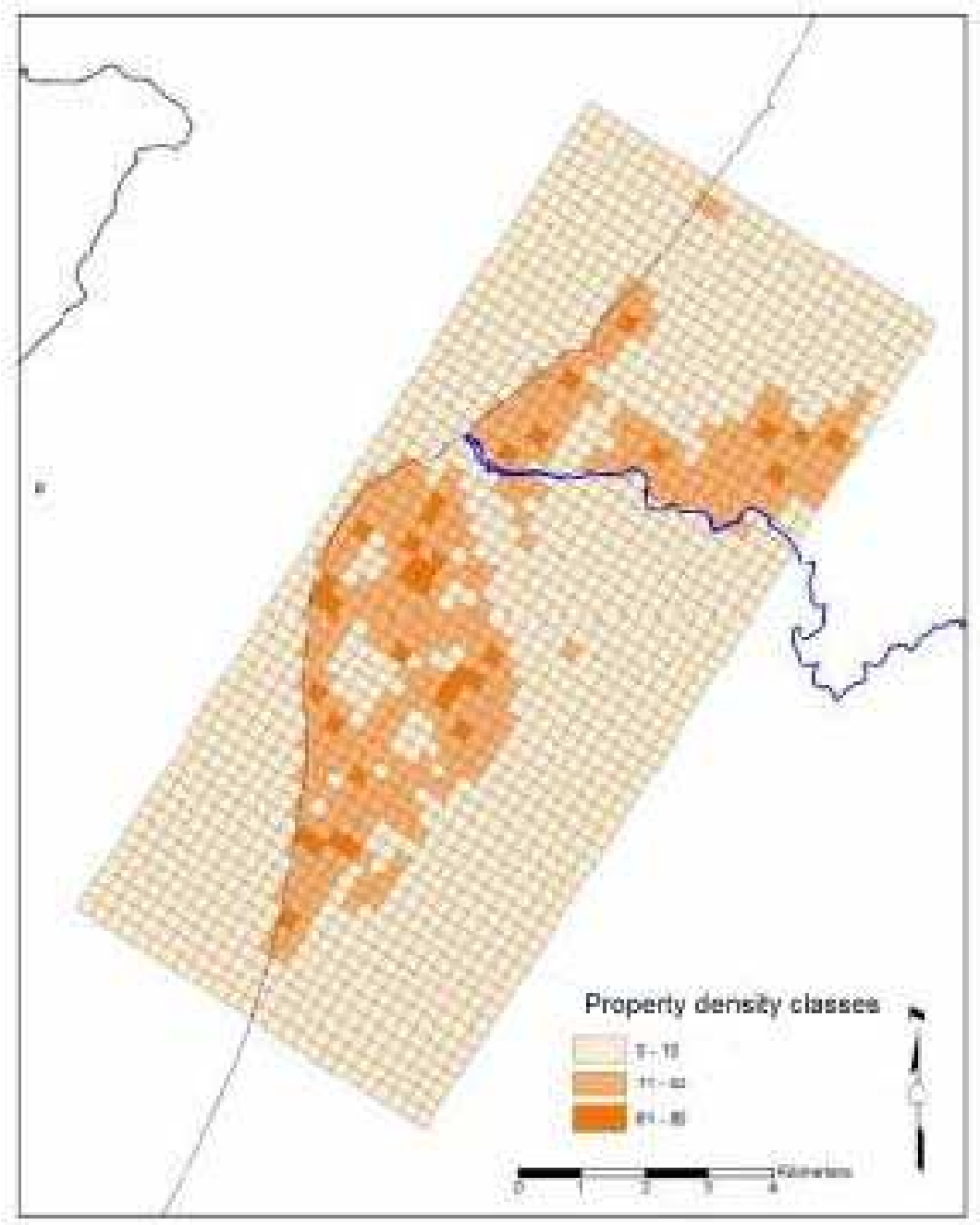

Figure 1.2: Property densities on the Kapiti Coast. Source: Jones and Gyopari (2005)

For each property density class, the potential irrigable area (i.e. garden and lawns) was estimated using aerial photographs of representative grid squares (Jones and Gyopari, 2005). The total potential abstraction was then calculated for the period $1 / 1 / 1997$ to $1 / 5 / 2003$ (Figure 1.3). 


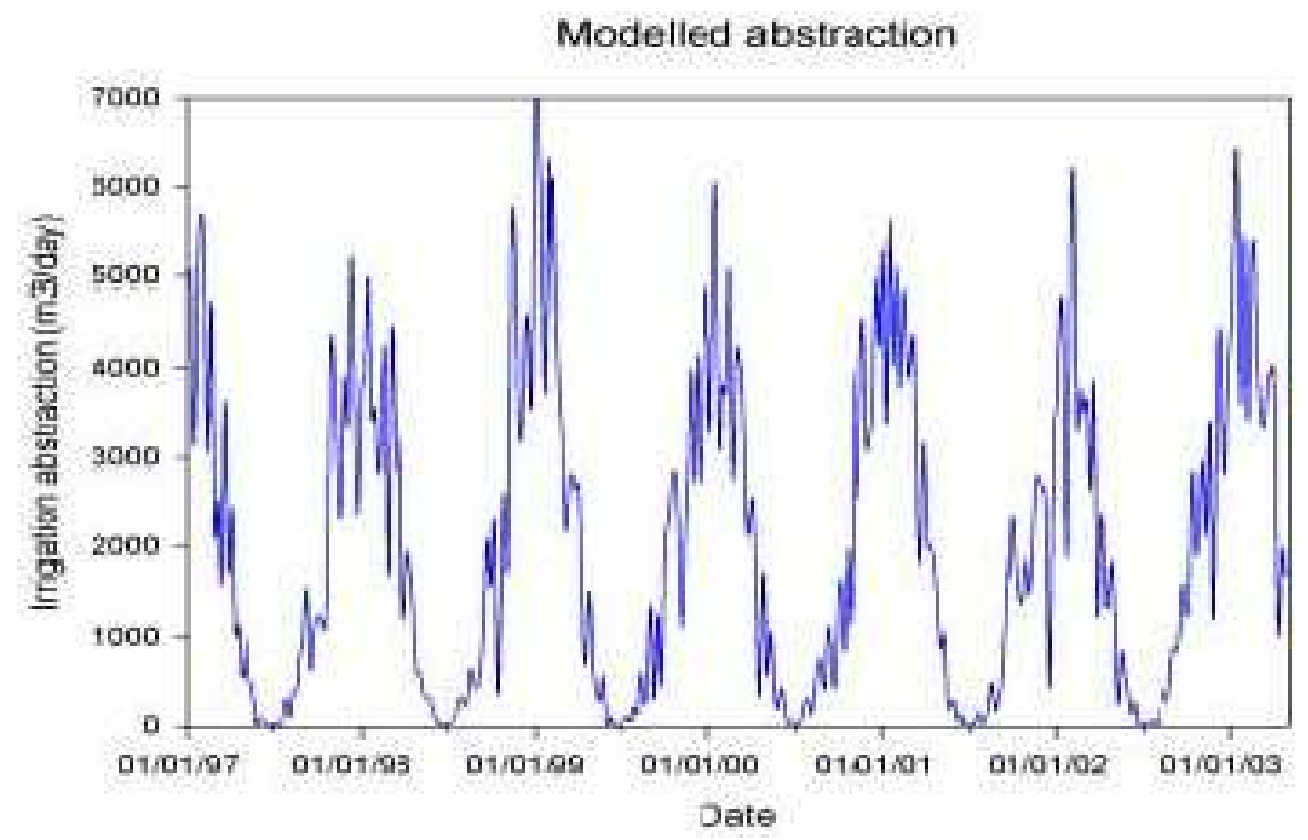

Figure 1.3: Modelled cumulative irrigation abstraction from the shallow sand aquifers on the Kapiti Coast. Source: Jones and Gyopari (2005)

Figure 1.2 shows the highly seasonal demand for irrigation water. The average daily abstraction is $2,000 \mathrm{~m}^{3} /$ day, peaking at around $6,000 \mathrm{~m}^{3} /$ day during the drier months of the year (Jones and Gyopari, 2005). This increased demand when the water balance tends to be in deficit places increased pressure on groundwater dependant ecosystems.

While wetlands are by their very nature transient ecosystems and are constantly changing over time, it is important to determine whether any changes are natural, or a response to anthropogenic activities. The 'life span' of a wetland system is dependant upon; type, climate, catchment, extent of anthropogenic modification and can range between a few hundred years and a few thousand (Williams, 1982).

\section{3: The Issue and Research Aims}

Wetlands are unique natural resources that play an important role in the hydrological cycle. There is a dynamic link between wetland hydrology and the inputs from both surface and groundwater resources. Shallow groundwater abstraction near the Te Harakiki wetland at Waikanae has the potential to impact on the wetland's hydrosystem. To assess the likelihood of this occurring, a detailed analysis of recent changes, the hydrological regime and water balance of the Te Harakiki Wetland system is needed. This research attempts to address some of these issues. 
This research therefore aims to:

- Assess the changes in wetland extent over time

- Quantify the hydrological controls on these changes

- Assess wetland response to natural climatic fluctuations

- Determine the nature, extent, and magnitude of surface water interactions within the wetland system

- Determine the nature, extent, and magnitude of groundwater interactions within the wetland system

- Assess the impact of shallow groundwater abstractions on wetland hydrology

- Assess the long term viability of the wetland

To achieve these aims the following objectives have been identified

Objective one: To assess how variations in climatic inputs and outputs affect the extent of the wetland system.

Objective two: To describe, and wherever possible quantify, the nature and dynamics of interactions between the surface water and wetland system. How do changes in surface water inputs and levels affect the wetland extent?

Objective three: To describe, and wherever possible quantify, the nature and dynamics of the interactions between the groundwater and wetland system. How do changes in groundwater inputs and outputs affect the wetland extent?

Objective four: To assess the impacts of shallow groundwater abstractions on the wetland. To determine how these abstractions affect the groundwater resources in the area, and consequently how these changes impact on the wetland ecosystem.

Objective five: From the above to assess the long term viability of the wetland and identify strategies that might ensure the sustainability of this unique ecosystem. 


\section{Chapter 2: Conceptual Background}

\section{1: Introduction: The Importance of Wetlands}

Wetlands provide important functions within the environment, such as flood mitigation, nutrient recycling and improving water quality (see Figure 2.1) (GW, 2003, Young, 1994 Commission for the Environment, (CfE) 1986). However, globally wetlands cover only a small fraction of the earth's land-surface. At the Ramsar Convention on wetlands (1971) it was estimated that wetlands covered around 7.48-7.78 million $\mathrm{km}^{2}$, or less than 9\% of global land area (Zedler and Kercher, 2005). There are, however, discrepancies between the various estimates of wetland extent because of the use of different definitions as to what a wetland is.

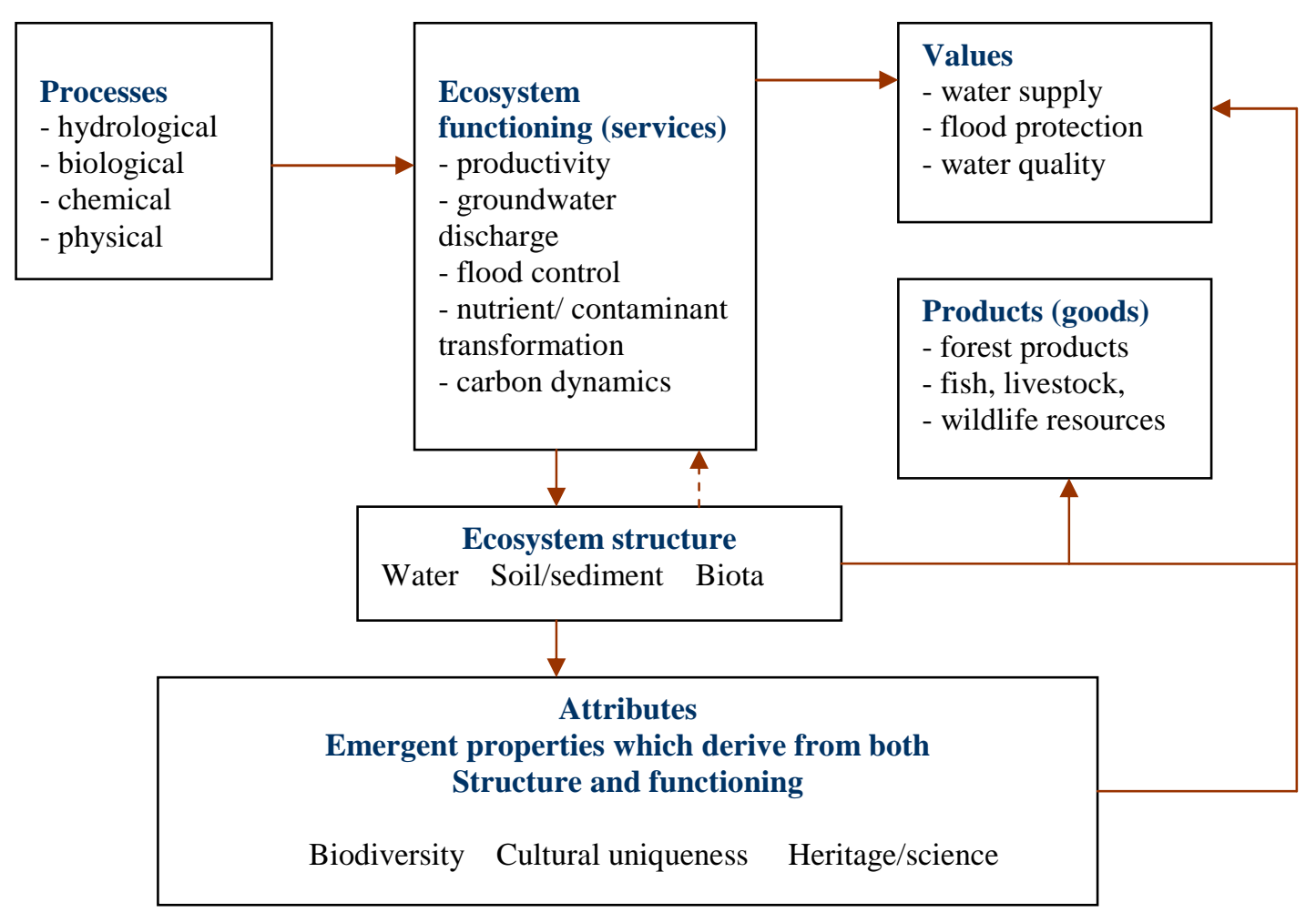

Figure 2.1 General functioning relationships within a wetland ecosystem Source: Maltby et al., 1994

There has been a dramatic, and well documented, decrease in the extent of wetland ecosystems world wide. It has been estimated that globally only $50 \%$ of those wetlands that existed in 1900 still remain (Finlayson and Davidson, 2007). The most dramatic losses occurred in northern temperate zones during the first half of the $20^{\text {th }}$ 
Century. Since the 1950's tropical and subtropical wetlands have increasingly been lost (Finlayson and Davidson, 2007). In Asia approximately $5000 \mathrm{~km}^{2}$ of wetland are lost annually. As a result of dam construction and agriculture (Zedler and Kercher, 2005). Estimates of the remaining area of wetland by region can be seen in Table 2.1.

Table 2.1 Global wetland area by region

\begin{tabular}{|c|c|}
\hline Region & $\begin{array}{c}\text { Area (Million Square } \\
\text { Kilometres) }\end{array}$ \\
\hline Africa & $1.21-1.24$ \\
\hline Asia & 2.04 \\
\hline Eastern Europe & 2.29 \\
\hline Western Europe & 0.29 \\
\hline Neotropics & 4.15 \\
\hline North America & 2.42 \\
\hline Oceania & 0.36 \\
\hline Total & $\mathbf{1 2 . 7 6 - 1 2 . 7 9}$ \\
\hline
\end{tabular}

Source: Zedler and Kercher, 2005.

The 'Convention on wetlands of international importance especially as waterfowl habitat' (The Ramsar Convention, 1971) addressed some of the issues associated with global wetland losses and proposed strategies to conserve the remaining wetland resources. The Ramsar Convention is an intergovernmental treaty which provides the framework for international cooperation to ensure the wise use and conservation of wetlands. The Convention entered into force in 1975 (Frazier, 1996). Contracting parties to the Convention are obligated to develop a national wetland policy, and to include wetland conservation and wise use considerations within their national landuse planning (Kobayashi, 1996). New Zealand ratified the Ramsar Convention in 1976, and was the first contracting party to develop a national wetlands' management policy in 1986 (Cromarty, 1996).

Finlayson and Davidson (2007) provided a link between the rate and extent of global wetland loss and degradation, and the issue of water allocation and distribution. Many rivers around the world have been heavily modified to satisfy increasing demand for 
hydropower and irrigation. This has resulted in increased salinisation, reduced groundwater resources, a decline in biodiversity, and impoverishment of fish stock from impeded migration and habitat degradation (Finlayson and Davidson, 2007). The adverse effects and consequences of wetland loss in industrialized countries are often mitigated by expensive artificial constructions, such as water purification plants. Wetland losses in developing countries are likely to have a greater negative impact as mitigation measures are less likely to be implemented because of technical and financial constraints (Moser et al. 1996).

Since European colonisation of New Zealand in 1850 approximately $90 \%$ of the $30,000 \mathrm{~km}^{2}$ of wetland area that existed at that time have been lost. The colonial attitudes of 'pushing back the frontiers of nature', and bringing 'worthless' land such as wetlands into agricultural production, dominated early New Zealand land use decisions (Cromarty, 1996). Some early cities, like Christchurch are built on wetlands.

The extent of wetland areas in New Zealand was estimated by Stephenson et al. (1983) using selected soil groups associated with poorly-drained soils (Table 2.2). Since that study it has been estimated that a further $7,000 \mathrm{~km}^{2}$ of wetland have been lost. Within the Wellington region it has been estimated, using soil maps, that wetlands once covered $1,030 \mathrm{~km}^{2}$, or $12.7 \%$ of the area. A study undertaken by Fuller (1993) found that wetlands in the region had been reduced to approximately $133 \mathrm{~km}^{2}$, i.e. only $13 \%$ of the original wetland area remained. Wetlands currently cover only $1.6 \%$ of the region.

Table 2.2 Wetland area $\left(\mathrm{km}^{2},\right)$ from selected soil groups.

\begin{tabular}{|l|c|c|c|}
\hline \multicolumn{1}{|c|}{ Soil Group } & North Island & South Island & New Zealand \\
\hline $\begin{array}{l}\text { Very poorly drained } \\
\text { (permanently wet) }\end{array}$ & & & \\
\hline Gley Soils & 2,000 & 1,000 & 3,000 \\
\hline Organic Soils & 1,800 & 200 & 2,000 \\
\hline Gley Podzols & & 3,000 & 3,000 \\
\hline $\begin{array}{l}\text { Poorly drained } \\
\text { (Seasonally wet) }\end{array}$ & & & \\
\hline Gley Recent Soils & 2,000 & 400 & 2,400 \\
\hline TOTAL & $\mathbf{5 , 8 0 0}$ & $\mathbf{4 , 6 0 0}$ & $\mathbf{1 0 , 4 0 0}$ \\
\hline
\end{tabular}

Source: Stephenson et al. 1983 
Of the remaining wetland area alpine and montane landforms are disproportionately represented. This indicates that the disproportionate loss of coastal and lowland wetlands was even greater than indicated by the above figures (Sorrell et al, 2004). The majority of the wetland losses have been caused by land drainage for agricultural or urban developments. Since the 1980's period of government restructuring, subsidies for land drainage for agriculture have been removed. It has subsequently become apparent that without financial assistance this land use practice was uneconomic (Cromarty, 1996). The loss of wetlands results in a decreased ability of the environment to buffer deep water aquatic systems from the influence of upland regions. As a result there has been a loss of valuable habitat, coupled with a decrease in water quality (Mitsch, 1994)

Remaining wetlands in New Zealand have been fragmented into smaller, isolated units. Because of their highly vulnerable nature, these wetlands remain under threat. Large areas of wetland are managed by the Department of Conservation, but there are significant wetland areas under Private, Maori and Local Authority ownership (Cromarty, 1996). Local authority plans in many areas offer limited protection for small wetlands on private land (Sorrell et al, 2004).

The Te Harakiki Wetland is a fragmented remnant of a much larger wetland system that used to extend three kilometres along a dune swale near Waikanae on the Kapiti Coast (Phreatos, 2002). The wetland is located on private land, and has been classified by Greater Wellington Regional Council as a 'groundwater depression swamp' (Phreatos, 2002). The Council has identified the wetland system as having significant ecological importance to the region because it is one of the largest, and most ecologically diverse, wetlands remaining in the area.

The wetland has been included as part of the Key Native Ecosystems Programme (KNE) (Jones and Gyopari, 2005, Phreatos, 2002). The KNE programme is designed to reduce and maintain introduced pest species to levels that allow remnant native habitats to re-establish (GW, 2007). A KNE is a natural feature on private land that is considered to be exceptionally important in terms of ecological value or biodiversity. To be eligible for the KNE programme the area needs to be legally protected by a 
covenant (GW, 2007). By their very nature wetlands are transient landforms, with variable spatial and temporal extent. They also undergo infilling as part of their natural cycle. Management of these systems, and their surrounding area that impacts on their variability, is therefore important. Such management, however, relies on sound knowledge of wetland behaviour, dynamics, and change. At present such knowledge is lacking specifically from the Te Harakiki wetland and indeed wetlands generally.

\subsubsection{Water Quality improvement}

Generally the water that runs off agricultural and urban land contains high levels of Nitrate-nitrogen $\left(\mathrm{NO}_{3}{ }^{-} \mathrm{N}\right)$, phosphorous, pesticides and heavy metals. These nutrients add to the eutrophication of water bodies (Zedler and Kercher, 2005). Wetlands have the ability to remove sediment, nutrients and other contaminants from water. It is often difficult to control the injection of these contaminants as they are generally by nature, diffuse or non-point source in origin (Crumpton, 2001).

Shallow water wetlands are effective at removing nitrates from the water column. Nitrogen is usually the most limiting nutrient for vegetation growth in hydric (wetland) soils. It is often available to wetland plants as ammonium ions $\left(\mathrm{NH}_{4}{ }^{+}\right)$or organic nitrogen from decomposing material in the soil (Berry, 1993). $\mathrm{NH}_{4}{ }^{+}$is oxidized to $\mathrm{NO}_{3}{ }^{-}$through nitrification by aerobic soil and plant bacteria. If the nitrogen is not assimilated by wetland plants it can be converted to nitrous oxide $\left(\mathrm{N}_{2} \mathrm{O}\right)$ or molecular nitrogen $\left(\mathrm{N}_{2}\right)$ through denitrification by anaerobic bacteria that are found in anoxic soil, common in wetlands. The bacterium in the soil converts the nitrate in the water to nitrogen gas and it is then lost to the atmosphere (Zedler and Kercher, 2005, Mitsch and Gosselink, 2007, Berry 1993). Molecular nitrogen can be converted into organic nitrogen through nitrogen fixation by bacteria in the rhizomes of some wetland plant species (Berry, 1993).

Phosphorous (P) is a limiting element for plant growth in freshwater wetlands as it can occur in both soluble and insoluble forms, which can be organic or inorganic 
(Berry,1993). It tends to attach to soil particles and does not cycle through the atmosphere. It may be unavailable to wetland plants in anaerobic conditions if it is bound as insoluble phosphorus and absorbed into the soil. It can be released in soluble form under anaerobic conditions in a flooded wetland soil environment (Berry, 1993). The best way to remove an excess amount of phosphorus from the water column is to trap sediment-rich water in a pond environment long enough to allow the sediment to settle out (Zedler and Kercher, 2005).

Wetlands have the ability to remove heavy metals, pesticides and industrial residue from water. These substances often bind to sediment or soil particles and the slower velocities of water through a wetland allow the particles to settle out (Maltby et al. 1994, Buxton, 1991). Plant surfaces (leaves, stems and roots) within the wetland supply attachment sites for microbes, which provide filtration and absorption of solids and add oxygen to the water (Buxton, 1991). The removal of nutrients from the water body prevents eutrophication, but each wetland has a limited capacity to absorb nutrients, and it is possible to overload and reduce the functionality of a system (Berry, 1993). There is a nutrient loading threshold in every wetland, above which aggressive species can come to dominate and therefore reduce the plant diversity (Zedler and Kercher, 2005).

\subsubsection{Flood Abatement}

Wetlands have the ability to abate floodwater flows by spreading out, storing and slowing flood waters (White et al. 2001, Jerry, 1988). However there is some debate as to the degree at which wetlands are able to perform this function. The ability of a wetland to lessen the effects of floodwaters is important when they are located upstream from areas where flooding is considered to be a serious issue, such as urban developments and high investment agriculture (Zedler and Kercher, 2005). The capability of wetlands to mitigate the effects of floods is dependant on their ability to store large quantities of water, reducing the height of flood peaks and the risk of downstream flooding (Zedler and Kercher, 2005, Buxton, 1991). The surface contours of the landscape, the subsurface soils, geology, and groundwater conditions of a wetland influence the capacity of the system to store water (Mitsch and Gosselink, 2007). 
Wetlands detain precipitation and runoff and so reduce flood peaks. They provide natural storage for water and decrease the need for engineering constructions (Maltby et al. 1994, Buxton, 1991). The ability of a wetland to reduce the effects of flooding are dependant upon factors previously mentioned as well as; surface area, depth, connections to streams and ponds, the type of wetland, and the degree of anthropogenic disturbance. It is possible to exceed the capacity of a wetland to store water. Many wetland systems are already at saturation point during the wetter parts of the year, they would have a reduce ability to provide storage for flood waters. By decreasing the velocity of runoff, wetlands can provide an important buffer between the sources of runoff and properties and infrastructure (Berry, 1993).

\subsubsection{Carbon Management}

More recently the role of wetlands in climate regulation has been considered more important, in light of the Kyoto Protocol (Zedler and Kercher, 2005). Wetlands are able to store vast amounts of carbon (C) in their soils. At a global scale wetlands are the largest component (up to $44 \%$ of $71 \%$ ) of the terrestrial biological C pool (Zedler and Kercher, 2005). Wetlands provide short term storage of carbon in trees, shrubs, other plants, soil and organic debris (Burkett and Kusler, 2000). Due to the anaerobic conditions found in wetland, carbon is stored for a much longer period than in other terrestrial ecosystems (Burkett and Kusler, 2000).

Wetlands also contribute more than $10 \%$ of the annual global emissions of methane $\left(\mathrm{CH}_{4}\right)$ and under certain circumstances can be a significant source of $\mathrm{CO}_{2}$ (Zedler and Kercher, 2005, Burkett and Kusler, 2000). The extent to which a wetland system acts as a source or sink of greenhouse gases is dependant the interactions that occur between the physical characteristics of the soil profile, vegetation types and microbial processes (Zedler and Kercher, 2005, Maltby et al. 1994).

$\mathrm{CO}_{2}$ is released from the wetland soil profile through heterotrophic respiration, in particular the decomposition of organic material. The amount of $\mathrm{CO}_{2}$ released increases exponentially with temperature and decreases with soil saturation and 
drought. When a wetland is drained the stored $\mathrm{C}$ decomposes and is released as atmospheric $\mathrm{CO}_{2}$. Predicted global temperature rises will increase the level of $\mathrm{CO}_{2}$ released from wetland soils (Zedler and Kercher, 2005).

Methane $\left(\mathrm{CH}_{4}\right)$ has a global warming potential 23 times greater than $\mathrm{CO}_{2}$. It is formed in soils characterised with anaerobic conditions, caused by prolonged water logging. $\mathrm{CH}_{4}$ is released to the atmosphere by diffusion through water or bubble formation and diffusion through aerenchyma tissue in vegetation (Zedler and Kercher, 2005). The levels of $\mathrm{CH}_{4}$ emissions vary dependant on the vegetation type present, the texture and acidity of the soil, and the quantity of plant litter present (Zedler and Kercher, 2005). The degradation or destruction of a wetland system would result in more $\mathrm{C}$ emissions than several thousand years of greenhouse gas emissions from a pristine wetland site (Zedler and Kercher, 2005). 


\section{2: Freshwater Management}

The management of freshwater resources (including wetlands) in New Zealand falls under the Resource Management Act (RMA) (1991). The RMA promotes the sustainable use, development and protection of natural and physical resources. Importance is placed on protecting the "life-supporting capacity of resources, safeguarding the foreseeable needs of future generations, and avoiding and mitigating adverse effects on the environment" (Fenemor and Robb, 2001). Instead of controlling activities such as groundwater abstraction, the RMA emphasises avoiding or limiting the environmental effects of the activities. The RMA encourages the integrated, holistic management of natural resources. This enables a catchment wide approach to be taken to the management of a wetland system. Much of the responsibility of resource management rests with the Regional Councils. The jurisdiction of the council's are physically defined on a watershed basis (Scott, 1993).

Section 6 of the RMA states that all water management decisions must recognise and provide for matters of national importance, including; the preservation of natural features, including wetlands, lakes and rivers [S6(a)], The habitats of indigenous fauna, public access to lake and river margins and Maori culture and taonga [S6(c)]. Greater Wellington and the current landowners at Te Harakiki have recognised this section of the RMA and are working closely together to preserve the natural character of the wetland.

Under Section 30 of the RMA Regional Councils have primary responsibility for water resources. This includes the "taking, use, damming and diversion of surface water, groundwater and geothermal water, maintaining and enhancing water quality and quantity, regulating the discharge of contaminants to land, air or water, controlling land use for soil conservation and other purposes and regulating the introduction of plants to water bodies" (Fenemor and Robb, 2001). The Regional Plan for an area set outs activities as "permitted, controlled, discretionary, noncomplying and prohibited. A permitted activity does not require a resource consent (Zuur, 1991). Under Section 14 of the RMA some uses of water are unrestricted, such as for fire fighting [S14 (3) (c)]. Water for reasonable domestic use (excluding 
geothermal water) is unrestricted provided there are no adverse effects on the environment [S14 (3) (b)] (Zuur, 1991).

Applications for rights to water through a resource consent are considered by the Regional Council. The RMA requires that an applicant provide the relevant Regional Council with an assessment of the environmental effects of the proposed activity (Cocklin and Blunden, 1998). Under the Greater Wellington Regional Council Freshwater plan, up until 2000, the drilling of shallow $(<6 \mathrm{~m})$ bores for residential use was a permitted activity and therefore no resource consent was required. In the Kapiti Coast area this has meant that there are many residential bores abstracting an unknown amount of water from the shallow sand aquifer. The amount of water available for allocation is specified in policy 6.2.3 of the Regional freshwater Plan as safe yield estimates for the various groundwater zones (Jones and Baker, 2005). The concept of safe yields is designed to prevent the long term reduction of aquifer storage by only allowing users to abstract no more than the estimated recharge volume for the aquifer. The groundwater abstraction rate is limited to the rate of replenishment to the system (Jones and Baker, 2005).

The 1986 "New Zealand Wetlands Management Policy" provides direction for the management of wetland systems. Objective 1.2 of the policy is "To protect wetlands of national importance, and where appropriate, wetlands of regional and local importance.” The Te Harakiki wetland system has been recognised as having regional importance. Objective 1.3 is "To gain adequate permanent protection of representative examples of all types of wetlands in private and public ownership. Priority will be given to preservation of the least modified and most ecologically viable of each kind." As already mentioned Te Harakiki is located on private land, the regional council has been working with the landowner under the KNE programme to ensure the preservation of the area. It is the largest and least modified dune swale wetland remaining in the Foxton Ecological District. Reports by the Department of Conservation Protected Natural Areas Programme (Ravine, 1992) and the Queen Elizabeth II National Trust identified the area as having high ecological values. The current landowners have protected the wetland area under the Queen Elizabeth the II National Trust Act, (1977) with a QE II open space covenant (Allen and Beadel, 2002). A QE II covenant is a legally binding protection agreement, registered on the 
title of the land. It is voluntary but once in place the current and all subsequent landowners must adhere to it. The area was originally protected between 1908 and 1929 as a "Sanctuary for Imported and Native Game" under the Animals Protection Act, 1907 (The New Zealand Gazette, 1908 and Park, pers comm. 2007) 


\section{3: Water Balance: Wetland Hydrology}

Wetlands exist in the transitional zone between terrestrial and aquatic environments (Mitsch and Gosselink, 2007, Burkett and Kusler, 2000), as a result of this, are sensitive to changes in water levels. Understanding the main drivers behind wetland hydrology is important. Wetland hydrology describes the water inputs and outputs, the quantities, flows and levels that occur in a given wetland. The hydrology controls the amount of nutrients entering and exiting, the chemistry of the water and soil, the nature of wetland substrate, the types of vegetation that are able to colonise the area, for which animals it provides a suitable habitat, and the productivity of the wetland itself (GW, 2005, Hollis and Thompson, 1998, Dungan 1994).

The hydrology of a wetland system is primarily influenced by the prevailing climatic conditions and the geomorphology of the area, as shown in Figure 2.2. It is also influenced by the catchment area and adjacent land use (Sutherland, 1982). Wetland systems are more common in areas with cool or wet climatic conditions. The geomorphology influences the location for the development of wetlands, for example, wetlands are less common on steep terrain than on flat or gentle slopes (Mitsch and Gosselink, 2007).

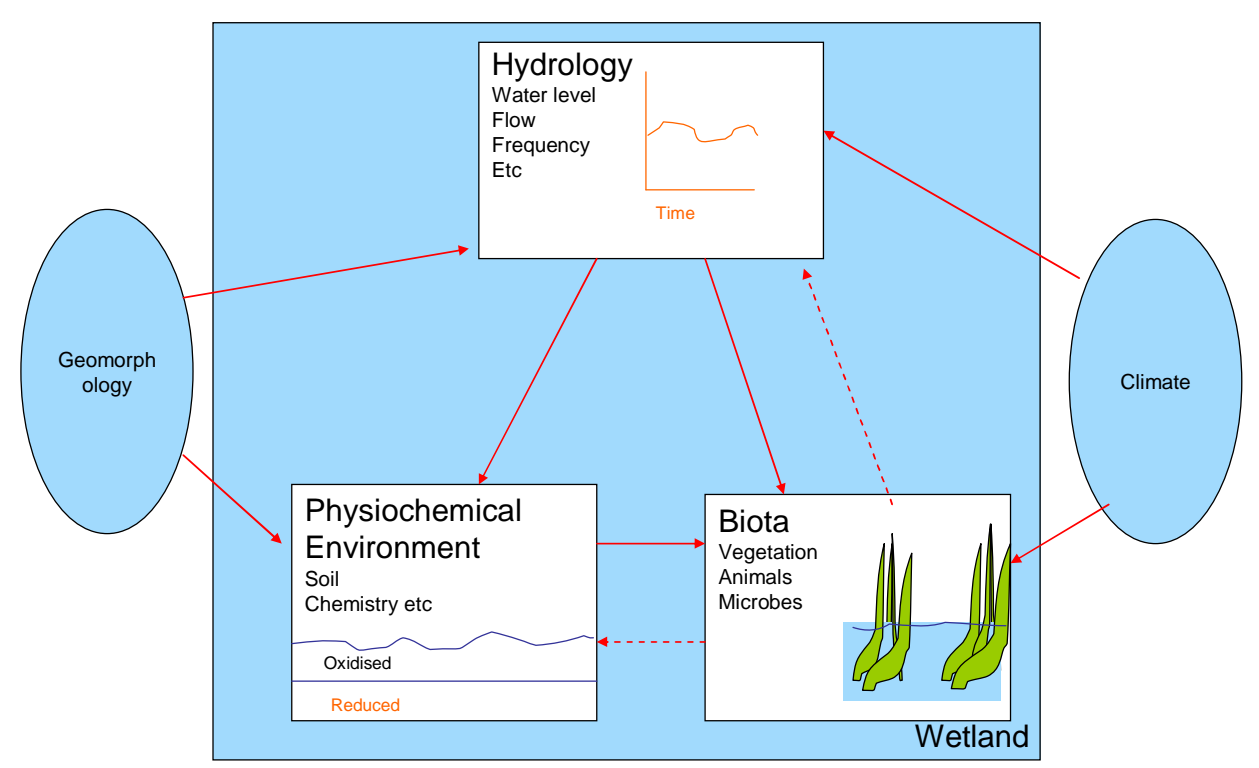

Figure 2.2 Main components of wetland by definition; hydrology, physiochemical environment and biota. Solid arrows show path of direct effect, dashed arrows, path of biotic feedbacks. 
The hydrology of a wetland system directly modifies and changes the physiochemical environment (the chemical and physical properties of the system), in particular the oxygen availability and related chemistry, nutrient availability, $\mathrm{pH}$ and toxicity (Mitsch and Gosselink, 2007). Hydrology transports sediment, nutrients and toxic material into a wetland. Water outflow from a wetland removes biotic and abiotic material such as, dissolved organic carbon, toxins, excess sediment and detritus. Modification of the physiochemical environment has impacts on the biota of a wetland. If the hydrological conditions change slightly the biota may respond with large changes in species composition and richness (Mitsch and Gosselink, 2007).

The biota of a wetland can also influence the hydrological conditions through feedback systems. Cybernitic control can influence the hydrology and chemistry of the environment, as microbes catalyze almost all chemical changes in wetland soils, so therefore control the availability of nutrients for plants and the production of phytotoxins such as sulphides. The vegetation of a wetland also has an influence on hydrology through peat building, sediment trapping, nutrient retention, transpiration and water shading. The binding of sediments can reduce the levels of erosion in a system; trapping sediment interrupts water flow, which can eventually decrease the duration and frequency of flooding cycles (Mitsch and Gosselink, 2007). 


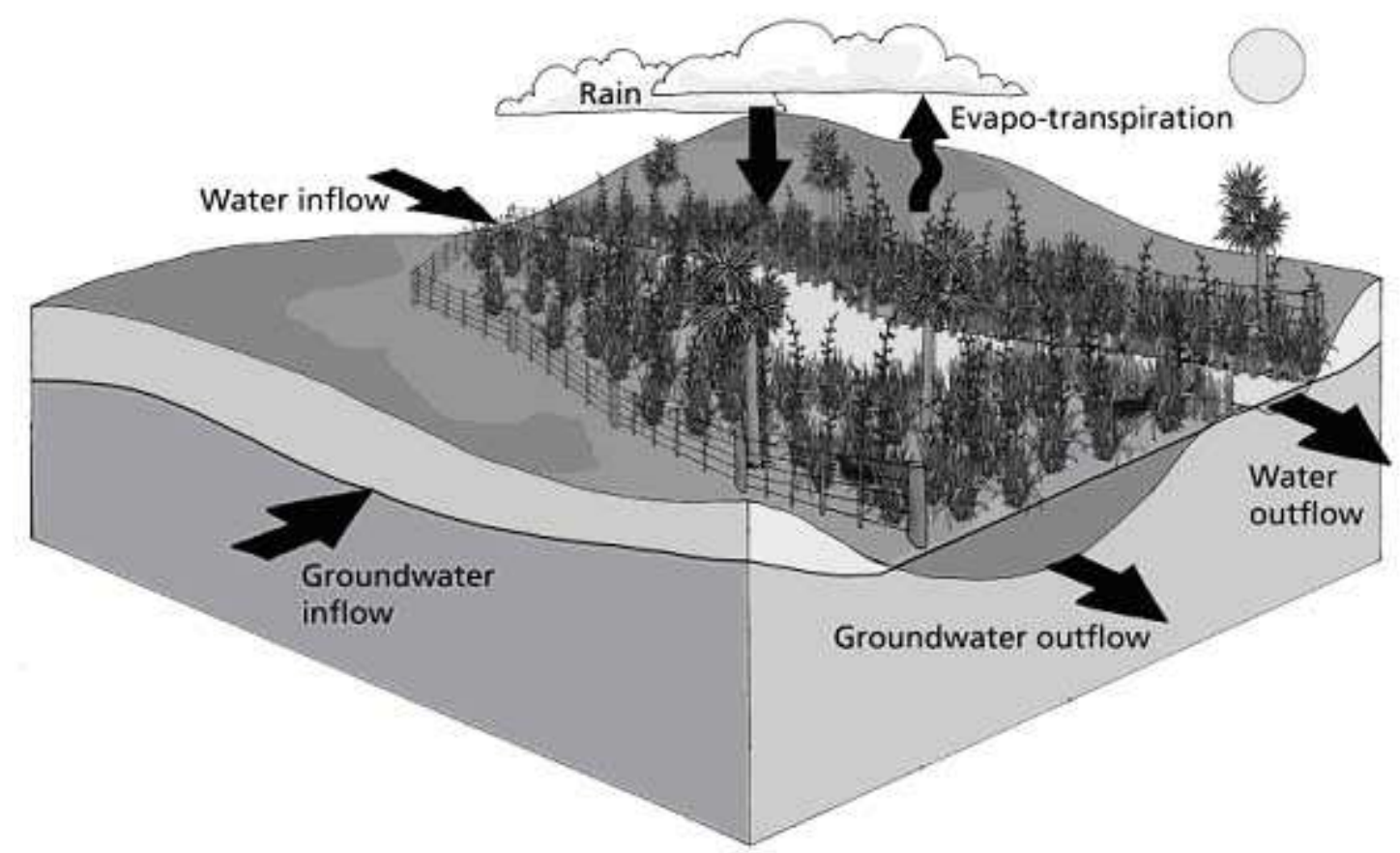

Figure 2.3 The components of a water balance for a wetland system Source: Greater Wellington, (2005)

The water flows and levels in a wetland system can vary greatly seasonally and from year to year. The hydrological regime or hydroperiod, of a wetland describes the variation in water storage and movement, within the wetland and across its boundaries. It is the result of the balance between the water inflows and outflows, the basin geomorphology and subsurface conditions (Mitsch and Gosselink, 2007, Berry, 1993). The hydrological regime of a wetland is important as it dictates the level and extent of many of the ecosystem services and functions carried out by the system. The hydrological conditions affect many abiotic factors such as soil anaerobiosis and nutrient availability, these in turn then determine the biota that can colonise the area (Mitsch and Gosselink, 2007).

The strong seasonal patterns found in a wetland are due to changes in solar radiation and rainfall intensities (GW, 2005, Campbell and Jackson, 2004). Variations in wetland hydrological regime are generally cyclic and determined by the timing and presence of surface water, the frequency and duration of inundation and drying cycles, the depth of surface water, the depth to the water table, the water sources and the variability of water levels; including depth and extent both seasonally and between years (Mitsch and Gosselink, 2007, Campbell and Jackson, 2004, Hollis and 
Thompson, 1998). The variables that affect this are set out as water inflows and outflows in Table 2.3 and shown diagrammatically in Figures 2.3 and 2.4.The hydrology of a wetland creates unique phyisochemical conditions that separate them from both terrestrial and deep water aquatic systems.

The difference between the inflows and outflows is defined as the water balance. The water balance for a wetland system can be calculated in the simplest terms by using the following equations:

Equation 2.1: $\quad$ Input - Output $=$ Change in storage

Equation 2.2: $\quad\left(P+Q_{\text {in }}+\mathrm{G}_{\text {in }}\right)-\left(E+Q_{\text {out }}+\mathrm{G}_{\text {out }}\right)=\Delta S$

Where: $\Delta \mathrm{S}=$ change in stored water within the wetland

$\mathrm{P} \quad=$ Precipitation

$\mathrm{Q}_{\text {in }} \quad=$ surface water inflows

$\mathrm{Q}_{\text {out }} \quad=$ surface water outflows

$\mathrm{G}_{\text {in }} \quad=$ groundwater inflows

$\mathrm{G}_{\text {out }}=$ groundwater outflows

$\mathrm{E} \quad=$ Evapotranspiration

Source: Campbell and Jackson, (2004) pp 20.4

Water Inflows Water Outflows

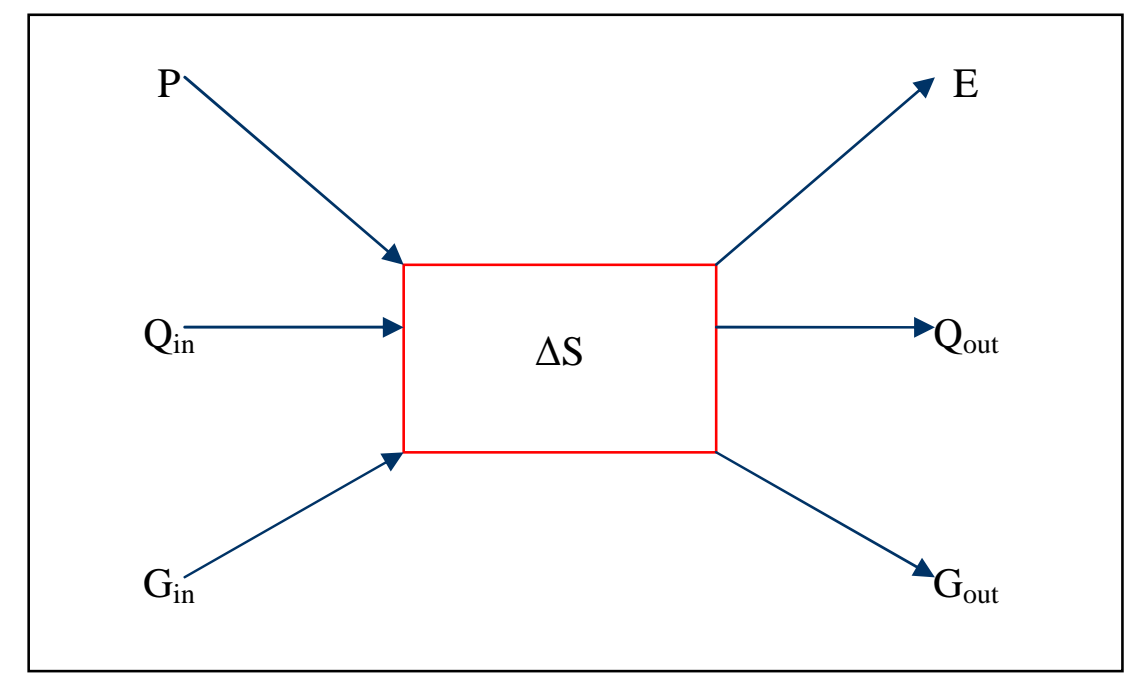

Figure 2.4 Schematic diagram showing the water inputs and outputs from a wetland, using the symbols from Equation 2.2

Source: After Mitsch and Gosselink, (2007).

Not all wetland types include all of the terms in the equation. When $\Delta \mathrm{S}$ is positive the total amount of water in storage in the wetland increases. This is shown most commonly by a rise in the water table and an increase in soil moisture content. If the 
change in storage is negative then there is a decrease in the total amount of water in storage and a lowering of the water table (Campbell and Jackson, 2004).

Table 2.3: Wetland water inflows (sources) and outflows (losses)

\begin{tabular}{|c|c|}
\hline Water Inflows & Water Outflows \\
\hline $\begin{array}{l}\text { Rainfall (Precipitation) } \\
\text { - } \quad \text { Rain that falls directly onto the wetland }\end{array}$ & \begin{tabular}{|ll} 
Evapotranspiration \\
- & $\begin{array}{l}\text { Evaporation from the standing water or } \\
\text { saturated soils }\end{array}$ \\
- & Transpiration from plants \\
\end{tabular} \\
\hline 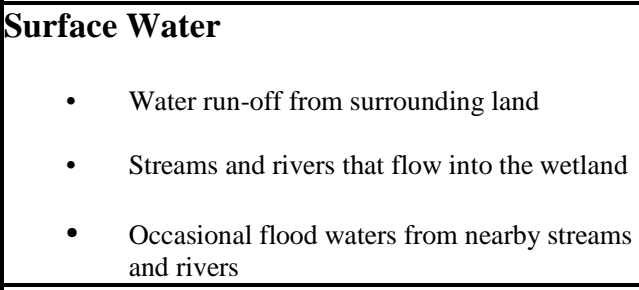 & \begin{tabular}{|l} 
Surface Water \\
- \\
Water run-off from the wetland \\
\end{tabular} \\
\hline $\begin{array}{l}\text { Groundwater } \\
\cdot \quad \text { Groundwater inflow }\end{array}$ & \begin{tabular}{|c|} 
Groundwater \\
$\bullet \quad$ Groundwater outflow
\end{tabular} \\
\hline
\end{tabular}

\subsubsection{Precipitation}

For precipitation or rainfall to occur several atmospheric conditions need to be met; a humid air mass must be cooled to the dew-point temperature, condensation or freezing nuclei must be present, droplets must coalesce to form raindrops and the raindrops must be of sufficient size when they leave the clouds to ensure they will not have completely evaporated before reaching the ground (Fetter, 2001, Gilman, 1964). In order to form raindrops warm air masses are cooled by adiabatic expansion, which occurs as air masses rise in the atmosphere. The atmosphere becomes less dense with increasing altitude; so rising air must expand due to the lowering of pressure. If no heat exchange occurs between the rising air mass and those surrounding it, then according to the laws of thermodynamics the temperature of the rising air mass will fall (Fetter, 2001). When an air mass reaches dew-point temperature, further lifting and cooling will result in condensation and the latent heat of vaporization is released (Fetter, 2001).

Precipitation in the form of rainfall, snow or dew, is often a major water inflow and included in the water balance for a wetland. Precipitation can fall directly onto the wetland area or reach it through other processes. Some precipitation may be lost through interception by vegetation. The rate of interception is greatest at the 
beginning of a precipitation event and declines exponentially with time (Mitsch and Gosselink, 2007, Fetter, 2001). Once the storage capacity of the leaf surface is expended, water then runs down the trunk or stem of plants, this stemflow can then reach the wetland.

The infiltration capacity varies between soil types and is different for dry or moist conditions in the same soil. If a soil is initially dry then infiltration capacity is high. Surface effects between soil particles and water exerts a tension that draws the moisture down into soil through capillary passages (Fetter, 2001). If the precipitation rate is less than the infiltration capacity, then all precipitation reaching the ground surface will infiltrate. Infiltrated water percolates through the soil profile vertically if there is uniform permeability. If layers of lower vertical hydraulic conductivity occur beneath the surface, infiltrated water, through flow, may move horizontally through the profile eventually entering the wetland.

\subsubsection{Evapotranspiration}

Evapotranspiration is generally the largest output, or water loss from a wetland. It is the combination of water transpired by living vascular plant tissue, and the evaporation from open water surfaces, precipitation intercepted by the canopy, from moist soil and non-vascular plants, such as moss (Campbell and Jackson, 2004). The levels of both evaporation and transpiration are controlled by solar radiation, the saturation vapour pressure deficit (a measure of the "drying power" of the air) temperature, humidity and wind speed. The levels of these vary diurnally, from day to day and seasonally, generally as a result of variations in solar radiation. Vegetated wetlands in general have lower evaporation rates than open water wetlands (GW, 2005, Campbell and Jackson, 2004, Ward, 1967).

Water molecules are continually being exchanged between liquid and atmospheric water vapour. If the number passing into vapour state is higher than those passing to liquid, evaporation is occurring. The rate at which exchange occurs depends on the water temperature and the temperature of absolute humidity of the layer of air just above the free-water surface (Mitsch and Gosselink, 2007, Fetter, 2001, Veihmeyer, 1964). Solar radiation is the driving energy force behind evaporation, as it warms both 
the water and the air. The rate of evaporation is also dependant on wind speed (Fetter, 2001, Ward, 1967).

Plants are constantly utilising water from the ground and expelling it into the atmosphere through transpiration. Water is drawn into the plant root system from soil moisture through osmotic pressure, it moves through the plant, and into the leaves. Transpiration is particularly important during the growing season, and is diurnal. It is limited by the availability of soil moisture (Fetter, 2001).

It is difficult to separate evaporation and transpiration in field conditions, so they are consider together as the total water loss, evapotranspiration. The potential evapotranspiration (PET) rate is the "water loss, which will occur if at no time there is a deficiency of water in the soil for the use of vegetation" (Thornthwaite 1994 in Fetter, 2001). This is the upper limit to the amount of water that will be lost through evapotranspiration. There is often not enough available soil moisture to reach the PE rate, actual evapotranspiration (AET) describes the amount of evapotranspiration that occurs in field conditions (Fetter, 2001). In some conditions AET is much less than PET, especially if the soil water storage capacity is limited. When PET is greater than the rainfall, some demand is met by utilising soil moisture. When the available soil water is depleted, the AET is limited by monthly precipitation levels (Fetter, 2001). Evapotranspiration usually occurs at the PET rate in a wetland system as the water table is at or near the surface and is therefore exposed to solar radiation and wind (Jerry, 1988).

Reference evapotranspiration $\left(\mathrm{ET}_{0}\right)$ allows the calculation of evapotranspiration independently of crop type it obviates the need to define a separate ET level for each crop and stage of growth as required when calculating PET and AET (Allen et al. 2006). The only factors affecting $\mathrm{ET}_{0}$ are climatic parameters. Consequently, $\mathrm{ET}_{0}$ is a climatic parameter and can be computed from weather data. $\mathrm{ET}_{0}$ expresses the evaporating power of the atmosphere at a specific location and time of the year and does not consider the crop characteristics and soil factors (Allen et al. 2006).

The rate of evapotranspiration in a wetland can be altered by grazing animals and the removal of vegetation cover; this changes the microclimate and increases rates of 
evaporation. Replacing native wetland species with exotics, in particular willows can have a drying effect in a wetland, as these particular trees have a higher rate of transpiration than many native species (GW, 2005).

\subsubsection{Surface water}

Many wetlands rely on surface water flows and are themselves an important part of river and stream systems. Wetlands can be fed by a stream, either permanently or when in flood, they can also be the source of a stream; its headwaters. Wetlands can also receive surface water in the form of run-off from surrounding areas (GW, 2005). Channelised surface water inflows or outflows, to a wetland allows traditional hydrological measurements with stage-discharge relationships. Surface water movement within a wetland through temporary or permanent channels, pools or flushes can cause variation in sediment and nutrient concentrations and have an influence on vegetation zonation (Campbell and Jackson, 2004).

Runoff generated in a precipitation event can be an important source of water to a wetland. Saturated overland flow was first described by Dunne and Black (1970). Rainfall infiltrates the ground to reach the water table, and the flux of water reaching the saturated zone causes the water table to rise until it reaches the ground surface (Davie, 2004). Overland flow occurs at this point, through the combination of precipitation falling on the already saturated soil and water returning from the saturated soil matrix (Davie, 2004). This form of overland flow is more likely to occur in an area where the water table is already close to the ground surface.

Hortonian or infiltration excess overland flow was hypothesised by Horton (1933), if the precipitation rate is greater than the infiltration capacity, then precipitation will initially infiltrate and as the infiltration capacity decreases, some precipitation will remain on the ground surface. If the precipitation rate is far greater than the infiltration capacity, some precipitation will remain on the ground surface immediately, this excess water flows as a thin film of water over the ground surface until reaches a channel of some form (Davie, 2004, Fetter, 2001). Hortonian overland flow occurs less often than saturated overland flow. 
Urbanisation effect the rainfall - runoff relationship within a catchment. Increased urbanisation results in an increase in the amount of impermeable surfaces in a catchment, such as roads, and pavements. The infiltration capacity is therefore greatly reduced (Ward, 1967). Precipitation falls on roads and rooftops, it is then sent through an artificial drainage network, designed to rapidly send runoff to nearby streams (Ward, 1967). This causes, there to be a marked increase in surface runoff in streams immediately below urban areas.

\subsubsection{Groundwater}

A large proportion of New Zealand's freshwater storage is in groundwater resources. Toebes (1972) estimated that $80 \%$ of the country's water supply is held as groundwater. The management of groundwater systems requires some knowledge as to the quantity of water stored within an aquifer (Fenemor and Robb, 2001).

Unconsolidated coarse-grained sediments, such as dune sands, represent some of the most profuse producers of groundwater. The intrinsic permeability of sediment is a function of the size of the pore openings. The smaller the size of the sediment grains, the larger the surface area the water comes in contact with. This increases the frictional resistance to flow, and decreases the intrinsic permeability (Fetter, 2001). The shallow sand aquifers of the Kapiti Coast consist of aeolian deposited material. These sands are moderately permeable $\left(10^{-4}-10^{-6}\right)$ and, form aquifers in areas where there is sufficient saturation. Porosities have been found by Freeze and Cherry (1979) to be between 30 and $45 \%$.

The movement of groundwater is subject to the influence of gravity, much like the movement of surface water (Ward, 1967). The difference in head between two points is the main driving force. The majority of groundwater movement occurs in material with small capillary spaces, so the resistance to flow imposed by the material of the aquifer may be considerable (Ward, 1967). The Law that shows the relationship between capillary flow and the hydraulic gradient is known as Darcy's Law. 
Darcy's Law states that the flow of groundwater is proportional to: 1) the slope of piezonmetric surface (hydraulic gradient) and 2) the hydraulic conductivity or permeability, the capacity of the soil to conduct flow.

Equation 2.3: $\quad \mathrm{q}=\frac{\mathrm{KH}}{\mathrm{L}}$

Where: $\quad q=$ the velocity of groundwater flow

$\mathrm{K}=$ hydraulic conductivity or permeability (length per unit time)

$\mathrm{H}=$ is the difference in head between two point separated by the distance $\mathrm{L}$

This equation is often re-written as:

Equation 2.4: $\quad \mathrm{Q}=K . A . i$

Where: $\quad Q=$ the volume of water flowing from a porous medium

$A=$ the cross sectional area

$i=$ hydraulic gradient

$K=$ hydraulic conductivity of the porous medium

Source: Ward, (1967) p 272

$K$ as a coefficient is dependant on the nature of the porous medium, but is also influenced by the physical properties of the water flowing through it (Ward, 1967). Factors that affect hydraulic conductivity can be classified into two groups; those relating to the water bearing material and those relating to groundwater as a fluid (Ward, 1967).

The movement of groundwater is generally very slow, making it difficult to determine the direction of flow, in some cases, knowing the direction of flow is very important (Ward, 1967). For example, a proposal is made to abstract water from an aquifer, before a consent can be granted, it is important to ascertain if, and to what extent the aquifer is being recharged. This can only be correctly assessed if the direction of groundwater movement through the aquifer is known (Ward, 1967). The general principles behind the movement of groundwater are implicit in Darcy's Law. 
Groundwater will move from an area of greater to an area of lesser head. For an unconfined aquifer, such as that at Te Harakiki, groundwater flow will be in the direction of the water table gradient (Ward, 1967).

The interactions of shallow groundwater systems and the surrounding environment are of particular importance to this study. Shallow groundwater systems interact rapidly and directly with climatic factors, such as rainfall and evaporation, as well as variations in the water level of adjacent water bodies (Ward, 1967). The Te Harakiki wetland is in direct contact with the Ngarara Stream, as it flows along the wetlands western boundary, and then flows southwards along the edge of the wetland, towards the Golf Course. As stated by Ward (1967) it can be expected that there will be movement of water between the two water bodies (the shallow groundwater system within the wetland and Ngarara Stream). Water flowing from the stream into the groundwater system is known as influent seepage, the reversal is effluent seepage. The relationship is generally dynamic, and will change with the levels of both the stream, and the groundwater system (Ward, 1967).

Short-term climatic fluctuations, such as storm events, have a much greater significance in shallow groundwater systems as the variations are reflected more rapidly as changes in groundwater level (Ward, 1967). The effect of rainfall on shallow groundwater is rapid, increases in the water table level usually occur within 24 hours of a rainfall event, although this is dependent upon the time of year and the soil moisture content of the intervening layers between the ground surface and water table (Ward, 1967).

Evapotranspiration can have both direct and indirect effects on shallow groundwater. The main indirect effect is reduction in soil moisture content through evapotranspiration, and the resulting influence this has on rainfall infiltration (Ward, 1967, Todd, 1964). Diurnal fluctuations in shallow water tables reflect the short-term direct effects of evapotranspiration. During the day, especially in summer months, the evapotranspiration rate can exceed the rate of groundwater inflow. During the night the rate of evapotranspiration is greatly reduced, allowing the water table to recover (Ward, 1967). Water table depth influences the rate of evapotranspiration, if the water 
table is near to the surface, then capillary rise of moisture contributes to the evaporative pressures of the vegetation (Ward, 1967).

Only a portion of the water within the aquifer is available to be abstracted. Changes within the catchment area such as the recharge zone, the levels of abstraction, and land use influence how much water is available for use (Fenemor and Robb, 2001). When assessing the level of groundwater abstraction in an area, more often or not small bores for residential, and stock water uses are not included, as many Regional Councils do not require consents for water used for these purposes, leading to the under-estimation of groundwater abstraction (Fenemor and Robb, 2001, White, 2001). It has been found by Acreman et al (2000) that abstraction of water from groundwater systems has had a detrimental effect on wetlands, and rivers.

As previously mentioned Regional councils are responsible under the RMA for placing restrictions on the allocation of groundwater resources. Groundwater is usually abstracted by pumping from boreholes and wells. The abstraction of groundwater from a well results in a fall in height of the water surface in the well, and the formation of a cone of depression around it (Figure 2.5) (Ward, 1967). The flow of water into a well is partly dependant on the hydraulic gradient (see Darcy's Law), the more the water level in the well is lowered, the greater the hydraulic gradient will become. The flow of water in to the well will also increase (Ward, 1967). For the proper development of a well, abstraction needs to exceed recharge over a localised area. If excessive abstraction takes place over a long period of time, from a large number of wells, it will result in a gradual lowering of the water table (Ward, 1967).

As the total volume of water abstracted from an aquifer increases, water levels and pressures within the aquifer decline (Fenemor and Robb, 2001). Eventually, the lowering of water levels, and pressure will have adverse environmental effects within the catchment, such as; preventing abstraction from wells, either due to "water levels falling below the intake screen of a well, or because pumping depths exceed the level from which it is economic to pump" (Fenemor and Robb, 2001). The effects of over extraction of groundwater on wetlands can be severe, and difficult to reverse. Prolonged reduction in groundwater levels, if carried over more than one winter period, have significant detrimental effects (Cussins, 1994). 


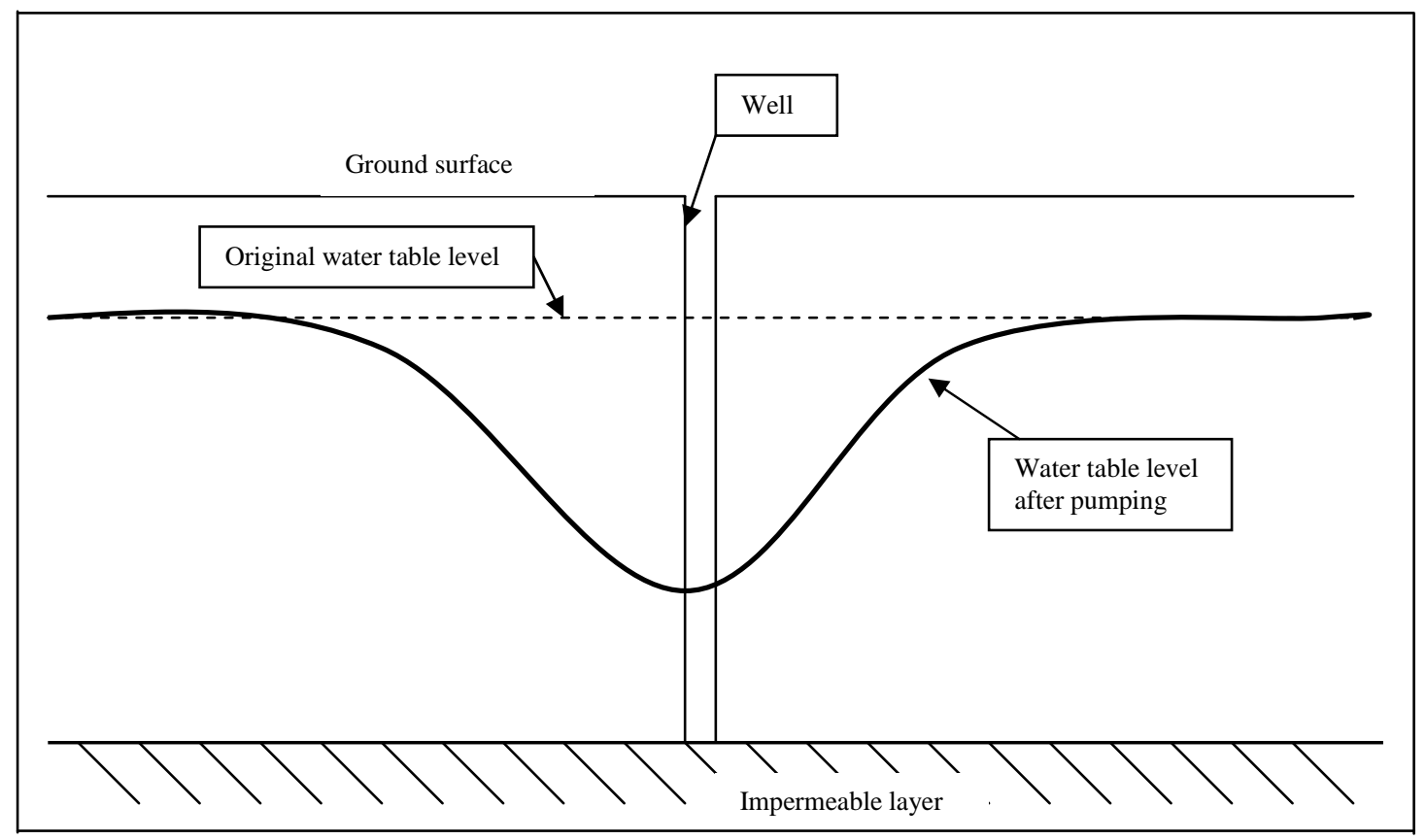

Figure 2.5 - Formation of a cone of depression around a pumped well Source: After Ward (1967)

Groundwater flow is an integral part of most wetland systems. Groundwater inflow creates a 'discharge wetland', and occurs when the wetland is located in a topographic low, where the wetland water level is lower than the surrounding water table (Mitsch and Gosselink, 2007, GW, 2005, White et al. 2001). Discharge wetlands are buffered against seasonal fluctuations in water levels. It has been found in wetland studies on the Kapiti Coast that groundwater discharge was an important factor in keeping wetland soils moist during the drier parts of the year (GW, 2005, Winter, 1999). Due to the interactions that exist, activities within a catchment area that affect the quality or quantity of groundwater resources can have a carry-on effect into a discharge wetland system (White et al. 2001).

A 'recharge wetland' is created when water flows out of the wetland, and into the groundwater system. This can occur when the wetland water level is higher than the water table in the surrounding area (Mitsch and Gosselink, 2007, GW, 2005, White et al. 2001). The interactions that occur between an interdunal wetland, and the groundwater system are often transient, and can vary seasonally, in some cases can even reverse during the year (GW, 2005, Winter 1999). 
The rate at which a precipitation event will recharge an unconfined aquifer system is influenced by the soil type overlying the water table, the effects of soil moisture capacity, and the infiltration rate of the soil (Cussins, 1994). Table 2.4 shows some soil types found in the Kapiti Coast area, gives a brief description of the soil and its soil moisture capacity (in $\mathrm{mm}$ ). Note the Waikanae Groundwater zone information is highlighted in purple.

Table 2.4 Soil Descriptions and soil moisture capacity values for the Kapiti Coast

\begin{tabular}{|c|c|c|c|}
\hline SOIL TYPE & $\begin{array}{c}\text { GROUNDWATER } \\
\text { ZONE }\end{array}$ & DESCRIPTION & $\begin{array}{c}\text { SOIL MOISTURE } \\
\text { CAPACITY (mm) }\end{array}$ \\
\hline $\begin{array}{c}\text { Kawhatau } \\
\text { (Ashurst) }\end{array}$ & Waitohu & Very stony silt loam & 100 \\
\hline $\begin{array}{c}\text { Kawhatau } \\
\text { (Ashurst) }\end{array}$ & Hautere & Very stony silt loam & 100 \\
\hline $\begin{array}{c}\text { Hautere } \\
\text { (Paraha) }\end{array}$ & Hautere & Silt loam & 150 \\
\hline $\begin{array}{c}\text { Motuiti and Foxton } \\
\text { Manawatu }\end{array}$ & $\begin{array}{c}\text { Waikanae and Coastal } \\
\text { Raumati }\end{array}$ & Sandy loam & 75 \\
\hline
\end{tabular}

Source: Cussins 1994, p 4.

The shallow unconfined aquifers in the Waikanae Groundwater Zone receive recharge primarily through rainfall infiltration. Recharge levels are spatially variable due to soil type, the underlying geology and land use. For the area around Te Harakiki there are two main recharge zones: Urban sand and non-urban sand (Jones and Gyopari, 2005). Watts and Hawke (2003) showed that urban areas on the Kapiti Coast intercept approximately $30 \%$ of rainfall. Jones and Gyopari (2005) calculated the non-urban recharge over sandy soil to be $535 \mathrm{~mm}$ annually.

\subsubsection{The Water Table and water storage}

Fluctuations in the water table are more apparent in a wetland than other terrestrial ecosystems (Campbell and Jackson, 2004). The position of the water table in relation to the ground surface is an important hydrological factor to take into consideration. Variations in water storage indicated by a change in water table position illustrates where significant boundaries lie within the soil profile (Campbell and Jackson, 2004). 
There is a strong link between water table and soil moisture content. When the water table is shallow, water lost through evaporation is rapidly replaced by capillary rise (Campbell and Jackson, 2004). If the water table drops to lower than normal levels due to a drought or artificial drainage of adjacent land, surface soil may become very dry, and the matric potential decreases dramatically once the larger soil pores are empty (Campbell and Jackson, 2004).

The hydraulic properties of wetland soil determine the relationship between water storage $(\Delta S)$ and water table fluctuations through the specific yield, as well as interactions between the wetland and regional groundwater flows and the rates of subsurface flow. The term specific yield is defined by Ingram (1993) as being the water yield, expressed as a depth, which results from a unit lowering of the water table. In the situation presented by a wetland, where the water sits at or above the ground surface, the specific yield will be close to unity, the yield will be less than unity below the ground surface and will typically reduce with depth as soil pore sizes decrease (Campbell and Jackson, 2004). Specific yield at the ground surface can be influenced by vegetation density and return a value less than unity.

The water table within a dune formation may fluctuate seasonally and in response to precipitation events. Levels will tend to be lower during the summer due to decreased precipitation and increase evapotranspiration rates (Phreatos, 2002). Under these conditions seepage to the dune swale from groundwater will maintain the wet root zone conditions required by wetland plants. The water table may be elevated during the winter due to increase rainfall recharge and decrease evapotranspiration rates (Phreatos, 2002). 


\section{4: Human impacts on wetlands}

Anthropogenic alterations and existing stresses placed on wetland environments cause them to be far more vulnerable to further impacts and changes in their hydrological regimes than most terrestrial ecosystems (Burkett and Kusler, 2000). This is often compounded as damage in one part of the habitat often results in the destruction of the entire system (Keller, 1988). These changes could include increased variation in water level and the frequency and duration of inundation and drying cycles. There are three main factors that influence the viability of wetland systems; the water level, the nutrient status and the level of natural disturbance (Mitsch and Gosselink, 2007). Human activities that modify any one of these factors can lead either directly or indirectly to an alteration of the wetland system.

Figure 2.6 shows some of the most common activities such as drainage, the discharge of storm water, flood protection works and over-extraction from surface or groundwater systems within the wetland catchment area that can cause changes to the hydrological regime and ultimately affect the viability of the wetland itself.

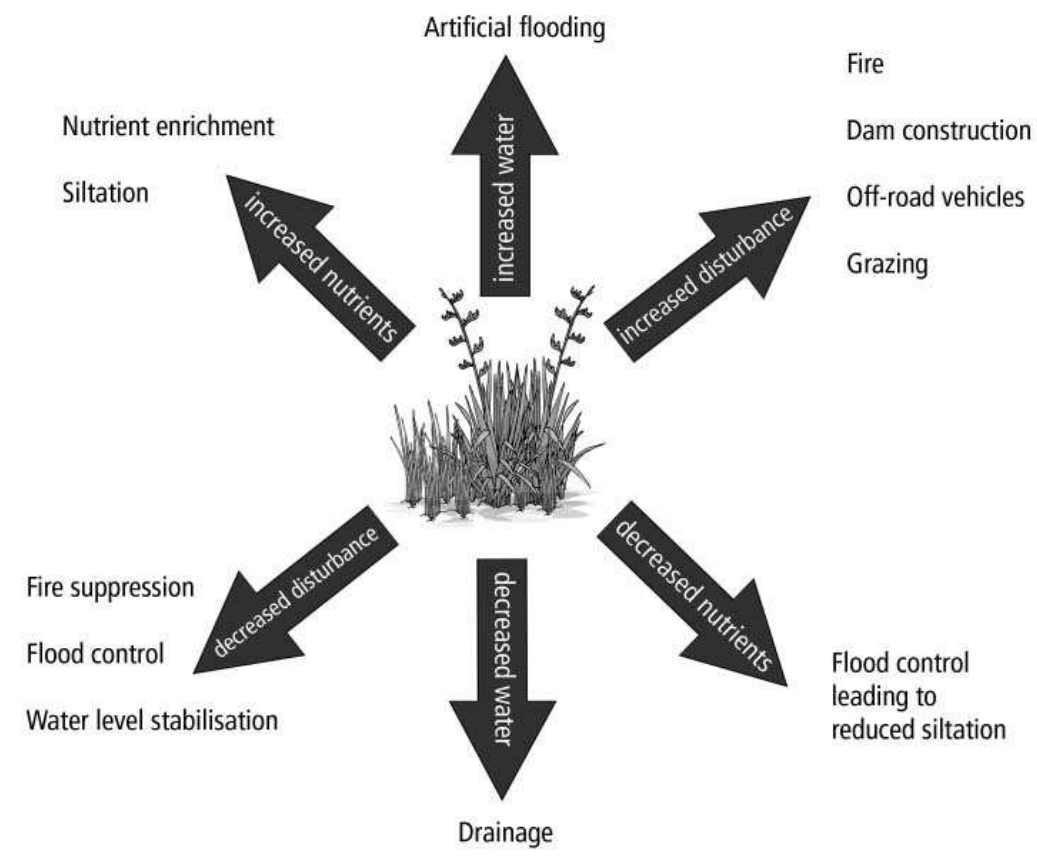

Figure 2.6 Major anthropogenic impacts on a wetland system as a result of changes in water, nutrients and disturbance levels.

Source: Mitsch and Gosselink, (2007) 


\subsubsection{Drainage, dredging or filling}

A major cause of wetlands drying up has been drainage, including the deepening of nearby drains. Wetland vegetation diversity decreases as water levels within the wetlands decrease, creating opportunity for dry land plants to colonise the area $(\mathrm{GW}$, 2005). Drainage of wetlands for agricultural purposes has been the main driver of wetland losses (Zedler and Kercher, 2005, Jones, 1993). Draining a wetland lowers the level of the water table and aerates the soil, changing the conditions from reducing to oxidising and allows chemical reactions that can be damaging to micro-organisms and plants (Zedler and Kercher, 2005, Jerry, 1988). The amount of aerobic microbial processes such as nitrate and oxygen respiration increases. Increasing the oxygen level of the soil causes the rate of decomposition to increase and therefore increasing the rate of $\mathrm{CO}_{2}$ release to the atmosphere (Zedler and Kercher, 2005). Nitrification is enhanced, which increases the nitrogen availability to plants, increasing the degree of competition between wetland and dry land plant species (Sorrell et al. 2004).

The drainage of wetlands has also lead to increased fragmentation of the remaining ecosystems. This prevents the natural migration of wetland plants from one location to another in response to temperature and water level changes (Burkett and Kusler, 2000). Resulting in decreasing habitat diversity, as plant community structure changes.

\subsubsection{Water pollution}

Eutrophication is one of the most important contemporary detrimental anthropogenic influences on wetlands. It is common issue where agriculture is the dominant land use in the catchment area. Run-off from agricultural and urban areas contains higher levels of nutrients, which allow aggressive plants to gain a competitive advantage and displace naturally occurring species (Zedler and Kercher, 2005, Johnson, 1996, Fuller, 1993). The eutrophication of a wetland can be attributed to either increased external inputs of nutrients or an acceleration of nutrient cycling within the wetland soil due to 
change in environmental conditions (Koerselman et al. 1993). Internal eutrophication can occur when the water levels of a wetland are lowered. Increased aerobic conditions allow more nutrients to be released, that would otherwise be unavailable to plants.

Eutrophication of open water bodies within a wetland system can result in phytoplankton and periphyton blooms and reduce the level of available dissolved oxygen in the water column (Zedler and Kercher, 2005, Sorrell et al. 2004). Increased nutrient availability stimulates microbial activity in the soil, making it more anaerobic, this places increased stresses on wetland plants through reduced soil oxygen levels and an increased concentration of phytotoxins (Sorrell et al. 2004).

Run-off from urban areas can decrease the water quality in a wetland as it often contains toxins such as oil and sediment. While not toxic in itself increased sedimentation in a wetland is still damaging as it can cause it to silt up (GW, 2005, Fuller 1993).

\subsubsection{Modification of the hydrological regime}

Artificially flooding a wetland can have detrimental effects. By decreasing the seasonal variations in water levels preferential selection is for plants that do not rely on these as clues for their growth cycle. Permanently flooding a wetland decreases diversity, as fewer species are adapted to deepwater and the wetland habitat becomes more homogenous (Sorrell et al. 2004). Resulting in the dominance by a few plant species $(\mathrm{GW}, 2005)$. An increase in habitat homogeneity also decreases the diversity of animals present in a wetlands system.

The ponding of water can also increase the rate sedimentation in a wetland, as lower velocities mean suspended sediments settle out (Sorrell et al. 2004). This is most often caused by increased rates of runoff from more urbanised areas or through the diversion of water from other areas. Urban development has a large and lasting impact on wetland hydrology. The creation of impervious surfaces, such as roadways and 
footpaths increases the rate of storm water run off. The increase volume and velocity of this run-off can result in flooding and erosion.

The implementation of flood protection and mitigation techniques can prevent the regular flooding of wetlands and therefore impact on their hydrology (GW, 2005, Fuller, 1993).

Anthropogenic or human impacts on a wetland can be caused by influences that extend beyond the boundaries of the wetland itself. The management of these systems needs to consider causes and consequences that extend beyond the immediate wetland boundary (CfE, 1986, Regnier, 1983). Wetlands are one part of the larger hydrological system, activities and impacts within the catchment area will have a carry-on effect within the wetland. Land use changes in the surrounding area create changes in the rainfall run-off characteristics of a catchment, such as the conversion of forestry to pasture (GW, 2005, Fuller, 1993). Once a wetland system has been severely modified it is often difficult if not impossible to return the system to its natural state. Some the values lost may be irreplaceable (CfE, 1986). 


\section{Chapter 3: Regional Setting}

\section{1: Geological Setting}

The landscape of the Kapiti Coast has been formed and shaped by the interaction of a variety of geological processes acting over a long time period. Figure 3.1 shows a generalised distribution of landforms. The impact of water on the landscape can be seen through both glacial and fluvial processes, the rise and fall of sea level resulting in erosional and depositional phases. Tectonic processes have also had a major influence the formation of the landscape (URS, 2003).

The steep hills that form the backdrop to the area (The Tararua Ranges) are composed of hard greywacke and argillite of Triassic age (c. 190-240 million years BP) (Heron and Van Dissen, 1992, Fleming, 1971, Te Punga, 1962). These rocks have been extensively faulted and folded. Material eroded from the Tararua Ranges is subsequently deposited downslope towards the Tasman Sea in a series of alluvial fans (URS, 2003). It is along the margin between the hills and the adjacent lowlands that the influence of climatic fluctuations and the subsequent rises and falls in sea level are most obvious. These changes during the Pleistocene (between 2 million and 14,000 years BP) have resulted in variations in material supply and character and these are now seen within the sedimentary deposits between the break in slope and the current shoreline (Heron and Van Dissen, 1992).

During cold periods, erosion increased in the Tararua Range and large amounts of 'frost-shattered scree' was formed and stored in the mountains (URS, 2004a). The coincident drop in sea level increased channel gradients and stream lengths and as a result, alluvial fans and extensive floodplains developed. Consecutive glacial events resulted in the deposition of fans and terraces at successively lower levels. Fine sediments such as silt, either exposed at the coast by lower sea level or deposited by flooding rivers, was carried by aeolian processes (transportation of sediment by the prevailing wind) and redeposited as loess on the surrounding slopes (Heron and Van Dissen, 1992). 
Intervening warm periods and interglacials, lead to a reduction in erosion in the mountains and a rise in sea level. Elevated sea level eroded a cliff in the glacial age depositis. Material deposited during previous glaciations was reworked to form beach sands and well sorted gravels. Onshore winds carried the sand inland and deposited it as dunes (Heron and Van Dissen, 1992).

At the end of the last Glaciation (10-15,000 years ago), sea level rose as the climate warmed. In response rivers cut degradation terraces in their middle and upper reaches and created new floodplains in their lower reaches. Approximately 6500 years BP, sea level reached its maximum, eroding a low cliff (the postglacial cliff) into the Pleistocene deposits. Progradation of the coast over the last 6500 years has 'reclaimed' an area of about $85 \mathrm{~km}^{2}$, and moved the coastline west from the postglacial cliff by up to $3.5 \mathrm{~km}$ (Heron and Van Dissen, 1992, Te Punga, 1962). Deposits of estuarine sand and gravel, dune sand, peat, and river gravel have accumulated between the postglacial sea cliff and the current coastline (Heron and Van Dissen, 1992).

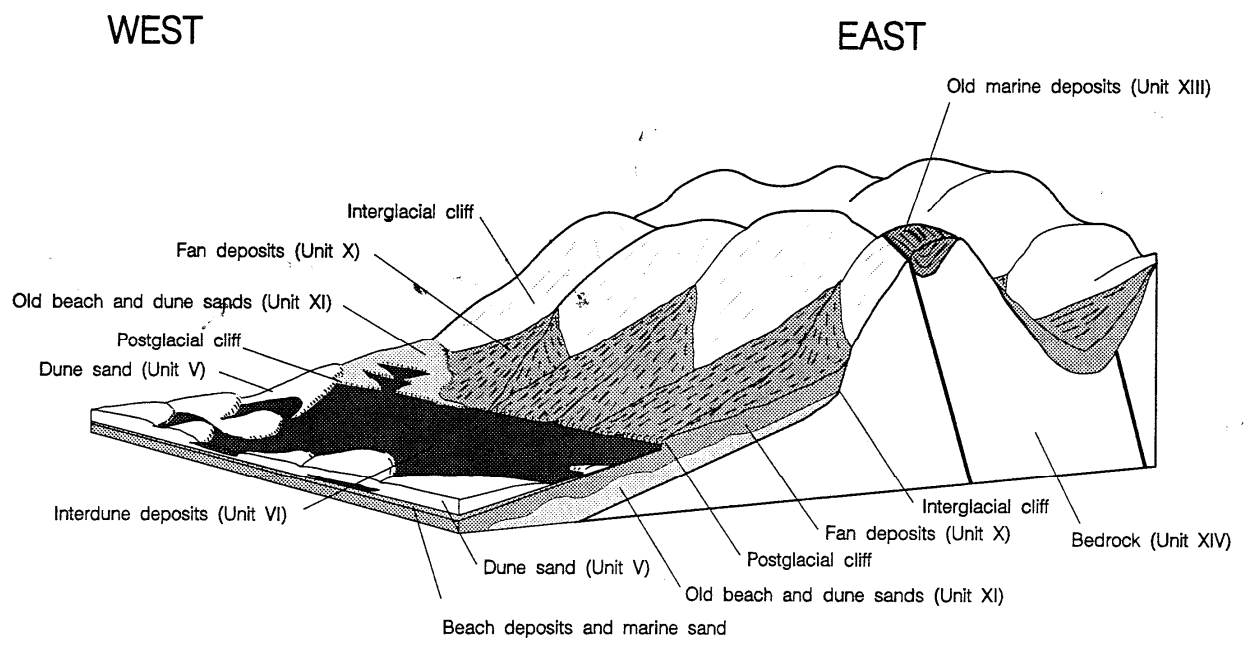

Figure 3.1 Diagram demonstrating the distribution of the main deposits on the Kapiti Coast. Bedrock (Unit XIV) forms the foothills. The margin of the foothills is mantled in old beach and dune sands (Unit XI) deposited during the last interglacial as the rising sea trimmed the foothills (forming the interglacial cliff). During subsequent glaciations alluvial fans (Unit X) were formed as erosional rates increased. About 6500 years ago, rising sea level trimmed the existing deposits (forming the postglacial cliff) As the sea retreated to its current position, beach deposits (Unit I), sand dunes (Unit V) and interdune peat (Unit VI) were formed.

Source: Heron and Van Dissen (1992) 
The subsurface geology of the area has been studied in some depth by URS (2003, 2004a and 2004b) and Stratigraphic Solutions (2003) to asses the hydrogeoloical potential of the area. Three main stratigraphic units were defined by these studies (Figure 3.2). Unit $\mathrm{A}$ is a shallow westward thickening hydrologically unconfined pocket of fine-sand-rich sediment. Its thickness averages around 20 meters, but it reaches 30 meters thickness at the present day coastline (URS, 2004b). Unit B is a deep, thick section of gravel rich rocks, with variable porosity. With the exception of the top segment it has little hydrological continuity with the overlying unit. It is at least 100 metres thick west of Ngarara Road (URS, 2004b). Unit C is the basement rock. In this area it is a hard, fairly impervious, greywacke. The depth to the basement increases westwards (URS, 2004b).

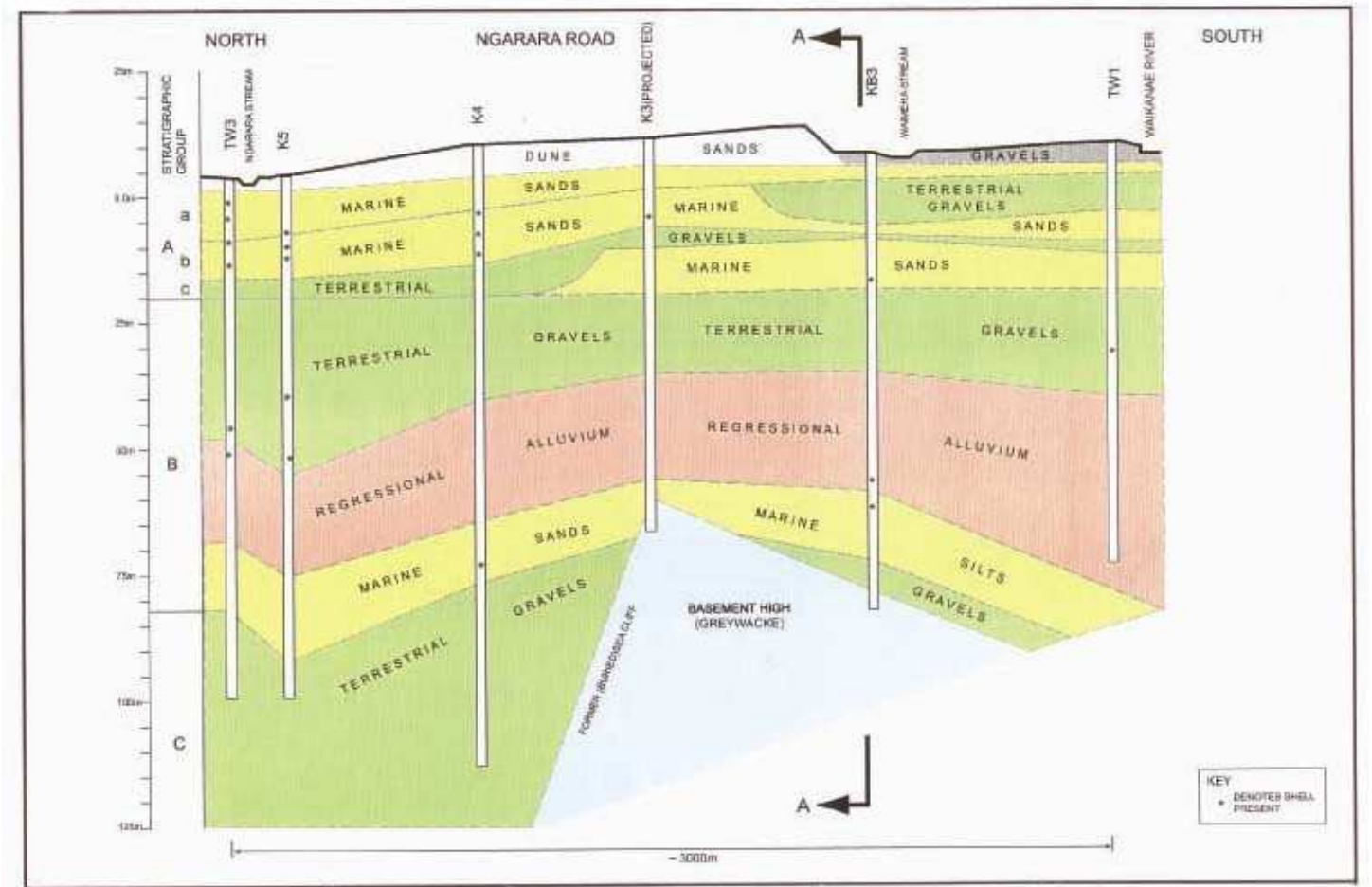

Figure 3.2 North - South geological cross section through the Waikanae coastal plain, based on data from bore logs. Te Harakiki Wetland is located between bores K4 and K5.

Source: URS (2004b)

The stratigraphic units on the Kapiti Coast are cyclothems, units with a cyclic pattern of deposition and erosion, that have resulted from the interaction between climate and earth deformation processes (URS, 2004b). In the Waikanae area, the usual pattern consists of a thin shallow marine bed, usually made up of well-sorted fine grained silt or sand (shown as yellow in Figure 3.2). This is followed by regressional alluvium, which tends to be rich in either sand or gravel (shown as red in Figure 3.2). These 
units are topped by terrestrial gravels that can be silt bound (shown as green in Figure 3.2) (URS, 2004b).

\section{2: Dune Formation}

The Kapiti Coast area is characterised by the presence of a large dune belt. The dune sands are derived from material brought to the coast by rivers and moved along the coast by wave action (McFadgen, 1997). The sand has been transported from the beach face, first to the foredune and then further inland, through aeolian processes. The sorting action of the wind produces uniform homogeneous, deposits on a local scale, in some cases deposits can be uniform over quite large areas (Freeze and Cherry, 1979). As sand accumulated, the shoreline generally grew seawards, and the foredune increased in height and width. The oldest dune formation along the coast is the Foxton phase which began accumulating about 6500 years BP. This phase forms the most extensive and distinctive belt that runs between Paekakariki and the Manawatu River, in some areas the dunes rise to $30 \mathrm{~m}$ above the surrounding plain (Hawke and McConchie, 2006, McFadgen, 1997, Fleming, 1971). There are three further dune phases younger than the Foxton dunes, along the coast i.e. the Taupo, Motuiti, and Waitarere phases. Near Waikanae the foredune at the time of the Taupo eruption is still a prominent feature in the landscape, and can be found just seaward of the Foxton dunes (McFadgen, 1997). These Taupo dunes were formed mostly from pumice granules derived from drift pumice that washed onto beaches following the Taupo pumice eruption (around 1800 years BP) (Fleming, 1971).

The Motuiti dunes also have a high content of sea-rafted pumice granules. This indicates that these dunes began accumulating around the time of the Taupo eruption. These dunes advanced over Foxton dune sand approximately 900 years BP (Phreatos, 2002, McFadgen, 1997). They also overlie traces of Maori occupation (Cowie, 1963). The Waitarere dune belt has been divided into two phases. The older Waitarere dunes were advancing inland, over the Motuiti dunes around 400 years BP. The younger Waitarere dunes overlie European artifacts and are younger than 150 years BP (Phreatos, 2002, McFadgen, 1997). 
Each dune building episode has two phases; an unstable phase when sediment is accumulating and a stable phase when soil forms (McFadgen, 1997). In many places along the coast, later dune deposits bury earlier deposits and soil profiles. Soils not buried by later deposits are ground soils. The ground soil for each dune forming episode has a characteristic degree of soil profile development (McFadgen, 1997). The distinctive profile of each ground soil is consistent across all dunes formed during the same episode and this allows each phase to be recognised from the degree of soil profile development. Dunes of older phases have more developed soils than those of younger phases (McFadgen, 1997). Soil profiles suggest that the dunes were formed episodically, rather than continuous dune formation and migration (Hawke and McConchie, 2006).

The Waitarere dunes have little soil profile development and the sands are relatively unweathered (Cowie, 1963). The advance of the Waitarere dune phase is attributed to overgrazing and burning of the original vegetation cover of stabilised dunes, as well as increased erosion inland from forest clearing and burning (Cowie, 1963). The dunes in the Motuiti phase have a rugged outline and are usually windrift in form. The dunes have a more developed soil profile than the Waitarere dunes, with shallow topsoil (around $15 \mathrm{~cm}$ ) and yellowish brown sub-soil (around $18 \mathrm{~cm}$ ) overlying grey sand (Cowie, 1963). The advance of the Motuiti dune phase is attributed to destruction of dune vegetation on stabilised dunes by the Maori. The Foxton dunes have a well defined topsoil of black sand (around $30 \mathrm{~cm}$ ) with a subsoil deeper and browner than that of the Motuiti dune phase. The Foxton dunes are older than the Taupo eruption as the sands lack pumice (Cowie, 1963). The formation of the dunes along the coast are controlled by wind velocity, the size and supply of sediment as well as the availability of suitable sites for accumulation (Hawke and McConchie, 2006).

\section{3: Study Area}

Hummocky dune landscapes, such as that found along the Kapiti Coast, are characterised by isolated depressions. These depressions can have a wide variety of sizes, shapes and altitudes as can be seen in Figure 3.3 (Winter, 2000). Wetlands in commonly occupy these depressions and have relatively shallow water tables (Winter, 
2000). There are extensive peat and wetland areas along the Kapiti Coast where the sand dunes have impeded natural drainage (URS, 2004a).

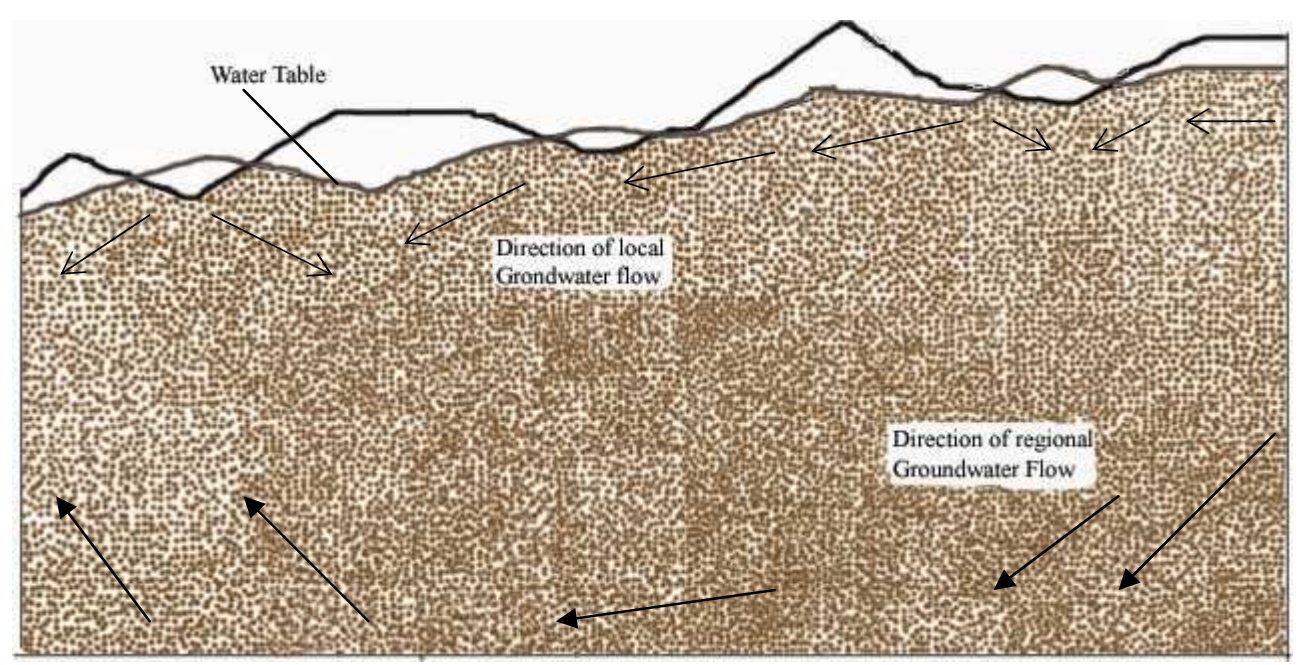

Figure 3.3 Generalised hydrologic landscape found in hummocky dune terrain. The arrows show the generalised direction of local and regional groundwater flow.

Source: After Winter (2000)

The Te Harakiki Wetland system is located just north of Waikanae Beach, approximately 500-600m inland from the present coast (Phreatos, 2002). The wetland lies within a linear interdunal swale located in the Ngarara catchment. The water table is within a metre of the ground surface (Phreatos, 2002, Ravine, 1992). Pumice rich sands (possibly Taupo dunesands) occur as a prominent line of dunes on the southern margin of the wetland. Foxton dunesands also border the southern part of the wetland while Waitarere dunesands are found on the northern and seaward margins (Phreatos, 2002) (See Figure 3.3). From its geomorphic position within the interdunal swale, the wetland is considered to be a relatively young landform, formed between 1000 and 1900 years BP (Phreatos, 2002). 


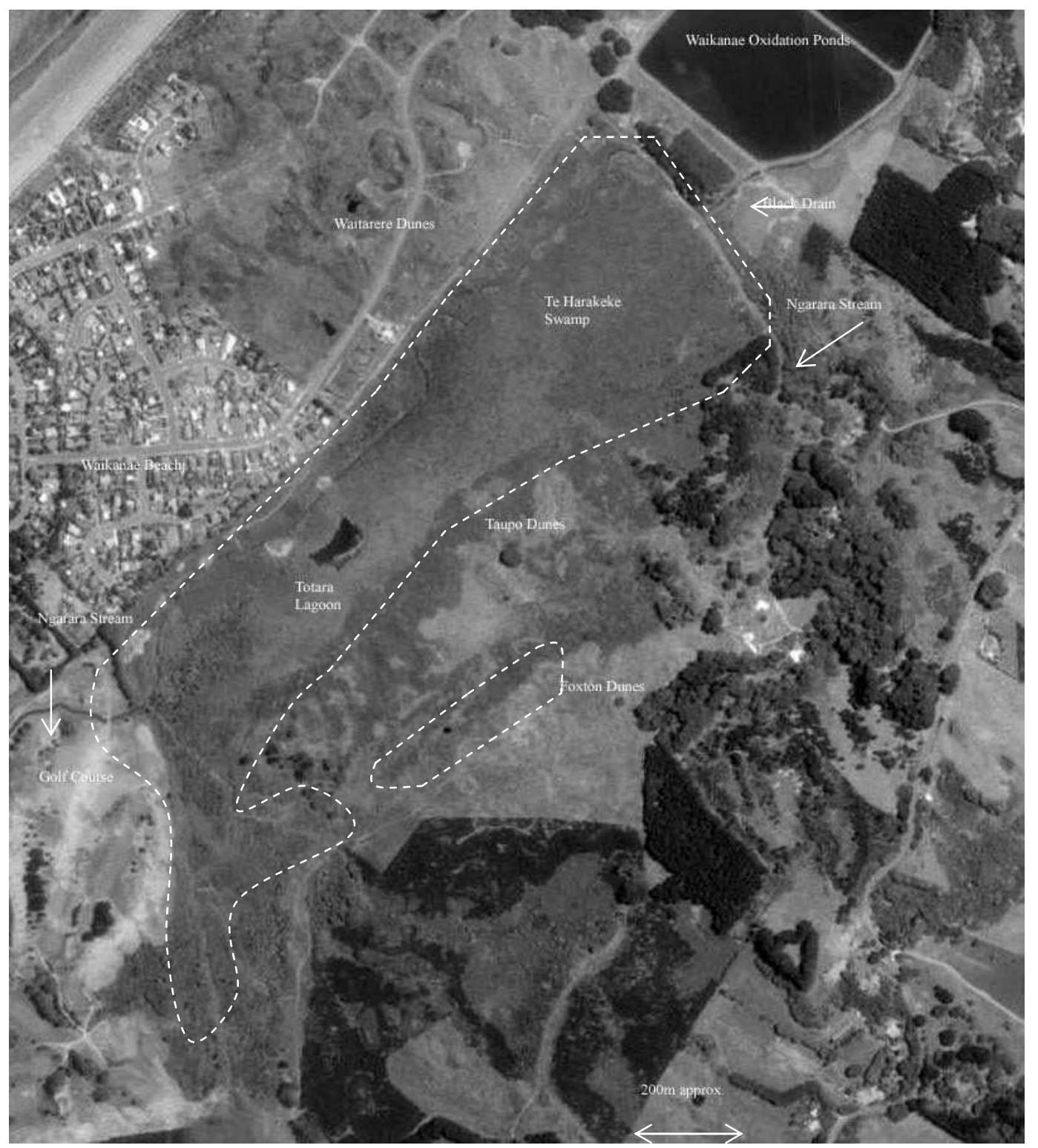

Figure 3.4 Aerial photograph of Te Harakiki showing the location of the wetland within the coastal dune system.

Source: After Phreatos, (2002)

The dune complex is formed from previous alluvial deposits of sand, mud, gravel and sea-borne volcanic (pumice derived) sand and ash that have been laid down over the last 6,000 years (Allen and Beadel, 2002). The geology of the area underlying the wetland system can be seen in Figure 3.2. Previously the wetland occupied the entire $3 \mathrm{~km}$ dune swale that extends north-east from the Waikanae Golf Course and runs parallel to the coast (Phreatos, 2002). The wetland was fragmented in the 1970's by the construction of the Waikanae Wastewater Treatment Plant. The wetland to the north of the oxidation ponds has subsequently been drained (Phreatos, 2002). (Can be seen in Figure 3.4). 
This study focuses on the remaining southern portion of the wetland. This area has undergone limited modification, and still retains its ecological significance. The wetland is located on private property and classified as a 'groundwater depression swamp' (Phreatos, 2002). The remaining area of the wetland is $1200 \mathrm{~m}$ in length and borders the Wastewater oxidation ponds to the north (Phreatos, 2002). The wetland extent is influenced by the topography of the dune system in which it is located. The main section of the wetland lies within the linear dune swale; but there are several lobes and isolated sub-parallel interdunal depressions located inland of the main swamp (Phreatos, 2002). At its northern end the main swamp is around 400m across; but it narrows to $250 \mathrm{~m}$ at the southern end. There is a small area of open water in the central part of the swamp, Totara Lagoon. It has been reported that over recent years that the lagoon has been shrinking (Phreatos, 2002). The Te Harakiki wetland system is considered to be of regional ecological importance. It is one of the largest lowland wetlands remaining in the southwest, North Island (Ravine, 1992).

Ngarara Stream flows through the wetland from the north to the south-west, in an artificially entrenched channel some $1-1.5 \mathrm{~m}$ deep. The water level in the channel is usually below the wetland water level (Allen and Beadel, 2002, Phreatos, 2002). In an effort to control flooding in the area, the stream was dredged under the Local Council Paetawa Drainage Agreement, which came into force at the turn of last century (Phreatos, 2002). Dredging has not taken place for a least the last thirteen years, and the stream only floods during extreme high intensity rainfall events (Phreatos, 2002). Prior to channel clearing and dredging it is likely that the Ngarara Stream would have frequently over-topped and flooded the wetland area.

The decommissioning of the Waikanae oxidation ponds in 2002, saw a decrease in flow of black drain (a small channel that flows from behind the oxidation and enters Ngarara Stream just upstream of the culvert) of 50\% (Phreatos, 2002). A corresponding drop in the level of Ngarara Stream of $0.1 \mathrm{~m}$ was also seen soon after decommissioning.

Phreatos (2002) found from assessing the water level in two monitoring bores, 1 close to Te Harakiki (McLauchlan, 2km to the south-east and Weka Park, at Raumati 
South) that there was a decline in groundwater level of around $0.5 \mathrm{~m}$ within the shallow dunesand between 1997 and 2002.

The reduction in flood pulsing as a result of anthropogenic channel modification from nearly a century ago, as well as a decrease in stream flow from the decommissioning of the oxidation ponds and a decrease in the groundwater levels in the area, may have resulted in changes in vegetation species composition, due to changes in the hydrologic regime (Phreatos, 2002). 


\section{Chapter 4: Methodology}

\section{1: Introduction}

The hydrological viability of the Te Harakiki wetland was undertaken using a combination of aerial photograph analysis and various field methods. A series of field sites were selected around the wetland (Figure 4.1) to provide good spatial coverage of the area, and complement existing Greater Wellington (GW) monitoring sites.

The methods provided data to assess the spatial and temporal changes in landuse within the wetland catchment during the 40 year period covered by the aerial photographs. Hydrometric time series data (rainfall, soil moisture, surface and groundwater) were used to assess the interactions between the various sub-systems within the catchment. They also allowed the calculation a semi-quantitative water balance for the wetland system. By combining the data acquired from the water balance and the interactions of sub-systems, historical changes in wetland area (from the aerial photographs) were explained. The long term hydrological viability of Te Harakiki was also assessed 


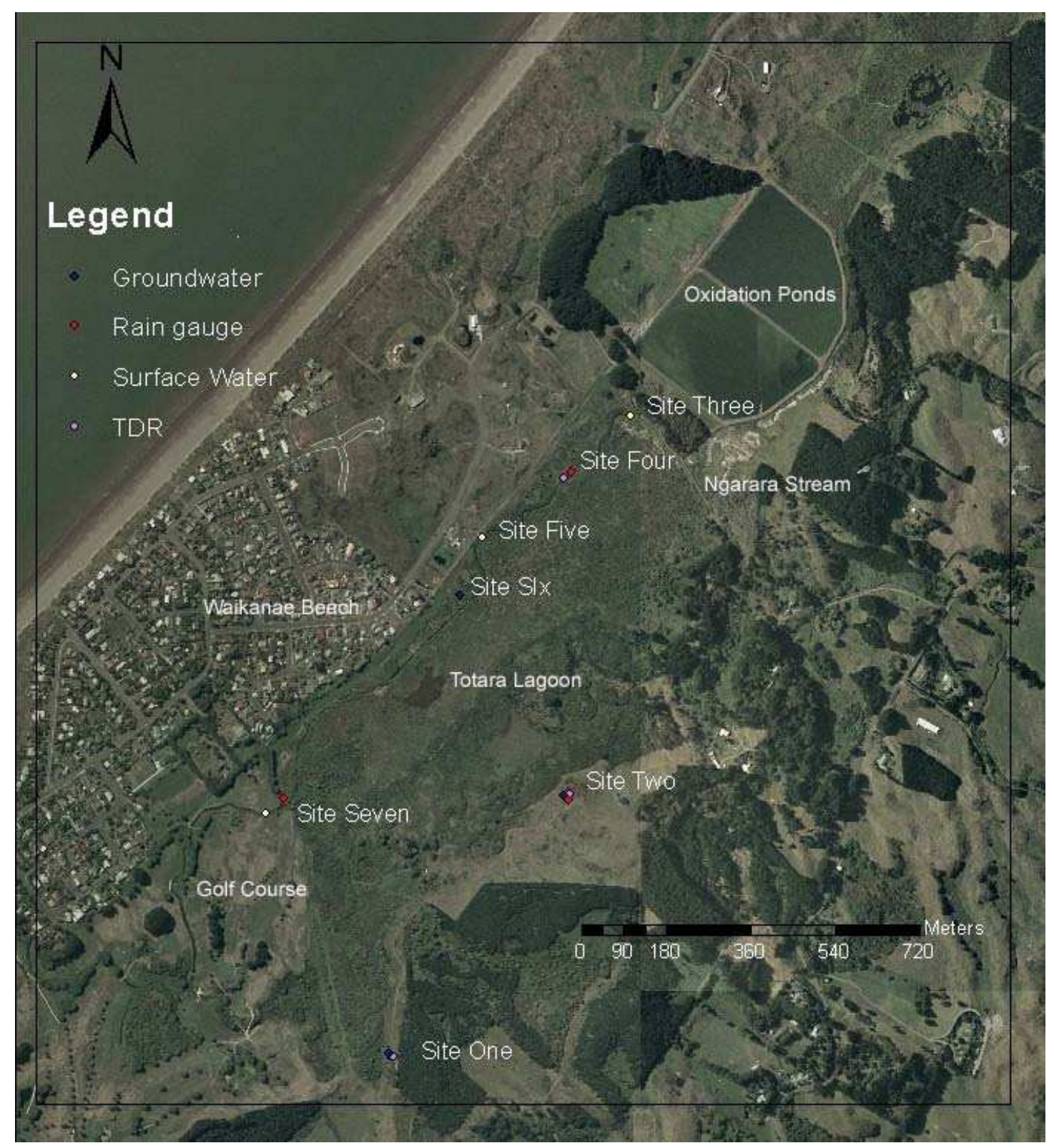

Figure 4.1

The location and distribution of field sites at Te Harakiki. 


\section{2: Aerial Photograph analysis}

Aerial photographs were obtained from New Zealand Aerial Mapping (NZAM) and GW. The photographs were chosen to provide temporal coverage of an almost 40 year period between 1966 and 2002. The photographs were approximately decadal; flown during 1966, 1978, 1986, 1996, and 2002. They were used to identify changes in wetland area and urbanisation within the catchment. Whenever possible they were chosen from series flown at similar times of the year, to minimise seasonal effects. The photograph runs from 1966 and 1996 were flown during April. The runs from 1978 and 1986 were flown in March. Photographs in 2002 were the only run flown specifically for GW also in March.

Each of the pre-2000 photograph series were georeferenced within ARCMAP (Version 9.1), using polynomial georetification. Ground control points (GCPs) were matched on the scanned images and the base layer. In this instance, the base layer was the previously georeferenced orthophotographs from 2002, overlain with the New Zealand transport and cadastral boundary maps. The later photographs (1986 and 1996) were the easiest to reference. This is because they contained easily recognised landmarks (used for GCPs) that could also be located on the 2002 georeferenced photographs.

The 1966 series consisted of a single aerial photograph that covered the study area. The 1978 series was of very high resolution and consisted of twelve photographs. This meant that some of the images where harder to georeferenced then others as they consisted of open farmland with few easily discernable hard GCPs (features with sharp edges or corners such as buildings). When necessary, soft GCPs were used (features with irregular or fuzzy edges such as the centre of individual trees) (Hughes et al. 2006). The 1986 series was flown at the highest altitude, giving the lowest resolution images. This series consisted of two photographs and was the most difficult to align. The highest error values are also therefore associated with this series. The wetland catchment is unfortunately located towards the edge of both images. Even with the overlap, aligning these photographs resulted in larger errors than for the other 
series. The 1996 series consisted of four photographs that were relatively straightforward to georeference.

\subsubsection{Rectification}

The number, type and distribution of GCPs influences the accuracy of polynomial georectification. Campbell (2002) suggests that most control points should be located around the edge of the image, with a few, uniformly placed points in the centre. Hughes et al. (2006) explains how this method of GCP distribution is often inappropriate for historical aerial photographs. Better accuracy may be obtained through the concentration of GCPs near the features of interest (Te Harakiki) rather than across the whole aerial photograph.

It was found that the use of GCPs at greater distances from Te Harakiki resulted in an unnecessary 'skew' of the aerial photograph towards topography that was unrelated to the study. The selection of hard or soft GCPs can also influence the accuracy of the georectification. Soft points are more difficult to locate accurately as they can change over time (e.g. when a tree grows larger) (Hughes et al. 2006). The location of the study site meant that it was necessary to use a combination of both hard and soft GCPs for georectification. Where possible hard points were selected over soft points.

Polynomial transformations with a curvilinear function can correct for some of the effects of geometric (related to topography and camera lens distortion) and radial (related to the curvature of the Earth) errors (Hughes et al. 2006). The photographs were all left as first order polynomial transformations as it was found, that because of the small area involved, higher order transformation excessively warped the images. Using a polynomial transformation, a least-squares function is used to fit the GCP coordinates on the scanned image to the base layer. This is then used to assign coordinates to the entire photograph (Hughes et al. 2006). After transformation the GCPs on the base and scanned mages will have slightly different coordinates. The difference in the location of the GCPs is represented by the total root-mean square (RMS) error. RMS errors are a measure of the goodness of fit of the GCPs and therefore indicate the images spatial accuracy (Green et al. 2000 in Meehan et al. 2005). A resampling step is required to equalise pixel size throughout the image and 
to assign values from the original to the transformed image (Hughes et al. 2006). Bilinear resampling was used for all images.

Table 4.1 Aerial Photograph details

\begin{tabular}{|c|c|c|c|c|c|}
\hline Year & Month & Scale & Emulsion & No. of Prints & $\begin{array}{c}\text { Total RMS } \\
\text { error }(\mathbf{m})\end{array}$ \\
\hline 1966 & April & $1: 17,000$ & $\begin{array}{c}\text { Black and } \\
\text { White }\end{array}$ & 1 & 1.487 \\
\hline 1978 & March & $1: 3,000$ & $\begin{array}{c}\text { Black and } \\
\text { White }\end{array}$ & 12 & 2.837 \\
\hline 1986 & March & $1: 20,000$ & $\begin{array}{c}\text { Black and } \\
\text { White }\end{array}$ & 2 & 1.501 \\
\hline 1996 & April & $1: 6,000$ & $\begin{array}{c}\text { Black and } \\
\text { White }\end{array}$ & 4 & \\
\hline
\end{tabular}

The images were overlain in ARCMAP ${ }^{\mathrm{tm}}$. Successive images were used to quantify changes in the size of areas of open water, and to assess increased urbanisation over the 40 year period. The images were enlarged on screen, and the extent of open water lagoons digitised using the mouse. Once the polygons representing the various areas were created, their area was calculated within ARC. The area of open water lagoon was used in this instance to represent the total wetland area as it was an easily discernible feature on all aerial photographs. The actual total wetland area was unable to be accurately mapped from the photograph series flown at larger scales. The urban area of Waikanae Beach settlement was also mapped in this manner to show changes in land use throughout the catchment.

\section{3: Climate analysis}

\subsubsection{Precipitation}

Precipitation was recorded for the purpose of calculating the wetland water balance and assessing soil moisture, surface and groundwater responses to rainfall events. Precipitation was recorded using tipping bucket gauges (Figure 4.2). Rain falls into the collecting funnel and is then led into one of the two compartments or buckets. When $0.2 \mathrm{~mm}$ (sites 2 and 4 ) or $0.25 \mathrm{~mm}$ (site 7) of rainfall has been collected the bucket over-balances (Ward, 1967, Gilman, 1964). This allows the falling rain to be directed into the other bucket, while emptying the rain that has just been collected 
(Ward, 1967). Each movement (or tip) of the bucket is recorded electronically and stored in a Campbell Scientific data logger.

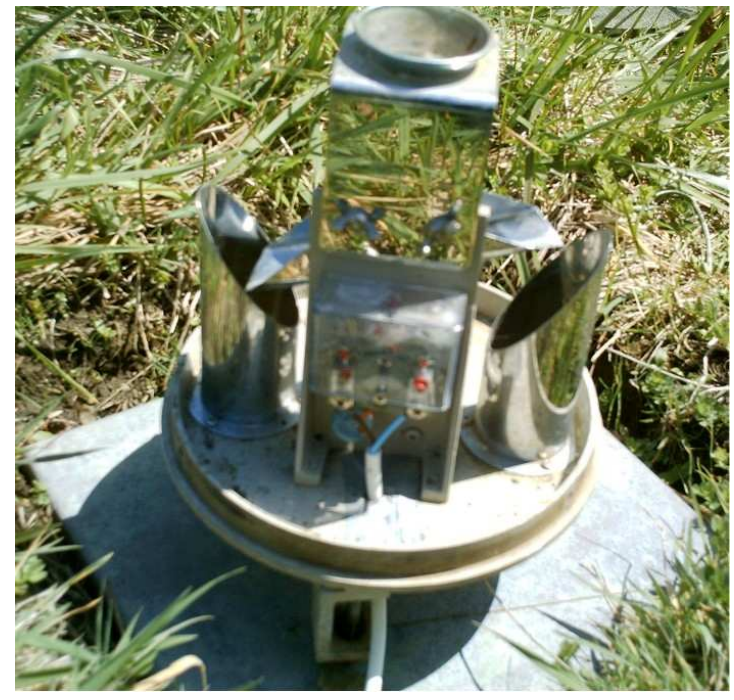

Figure 4.2

The mechanism within a 'tipping-bucket' rain gauge. This particular gauge was installed at Site 7, but was later replaced following vandalism that destroyed the gauge.

Three gauges were located around the study area. They were positioned in relatively open areas and away from trees (Figures 4.3 - 4.5). The gauges were located on level ground, with the top of the gauge being horizontal, checked against the level attached to the base of each gauge.

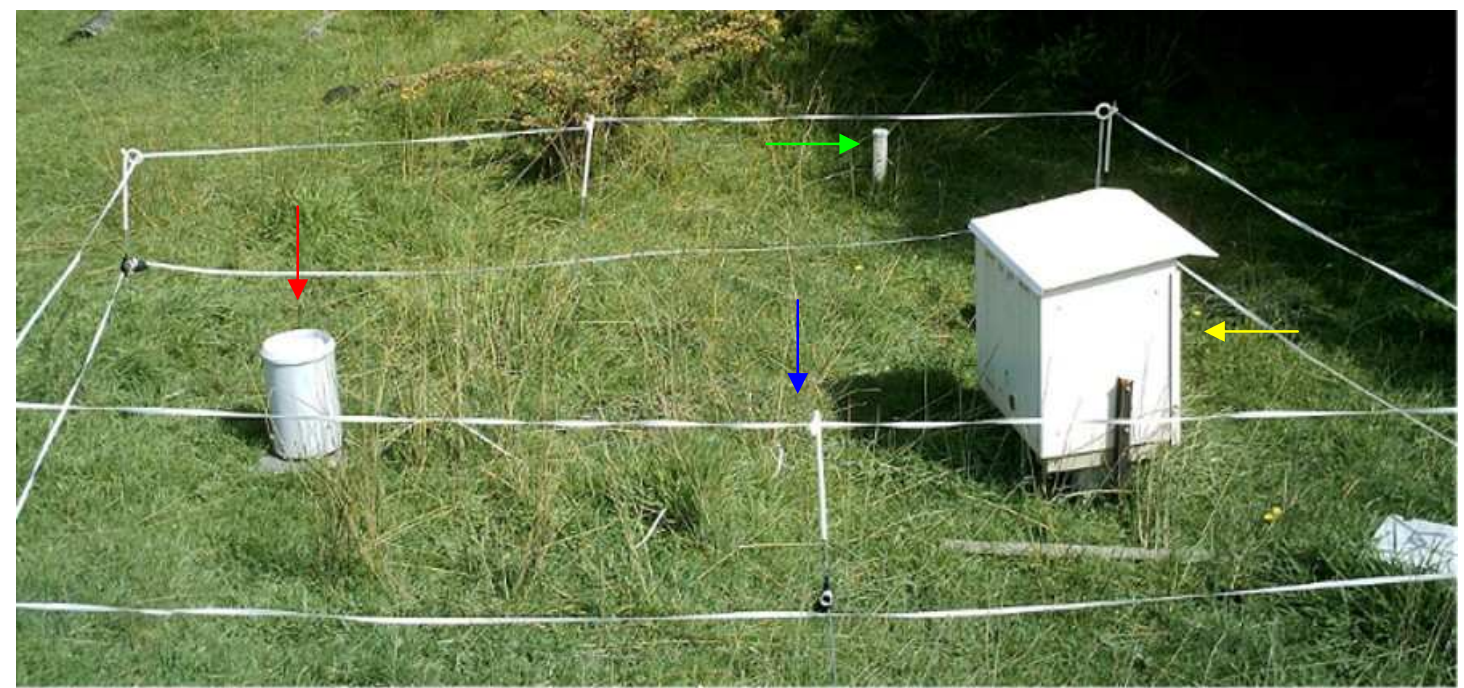

Figure 4.3

The distribution of equipment at Site Two. The site contains a tipping-bucket rain gauge (red arrow), a set of TDR probes located underground (blue arrow) with the data logger housed in the white box (yellow arrow). In the background of the photograph, the top of the bore casing for groundwater monitoring can also be seen (green arrow). 


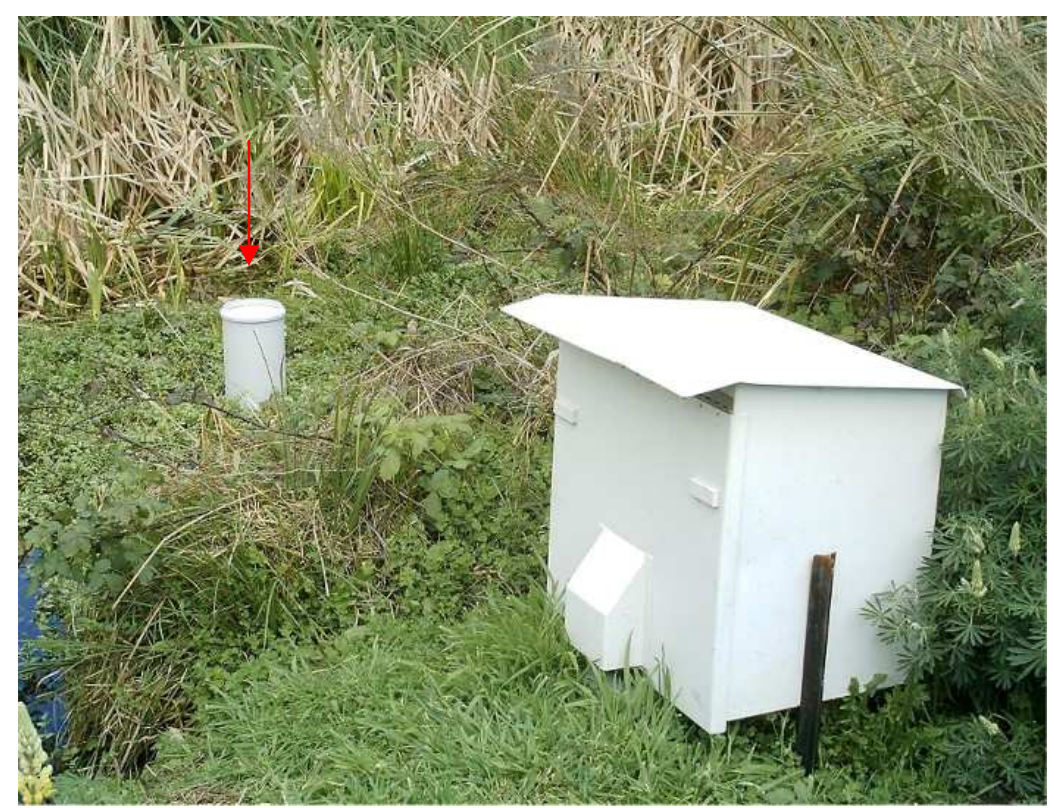

Figure 4.4

The location of the monitoring equipment located at Site 4. The rain gauge can be seen (red arrow). The site also has TDR probes that are located underground just beyond the scope of the photograph near the warratah that supports the data logger housing.

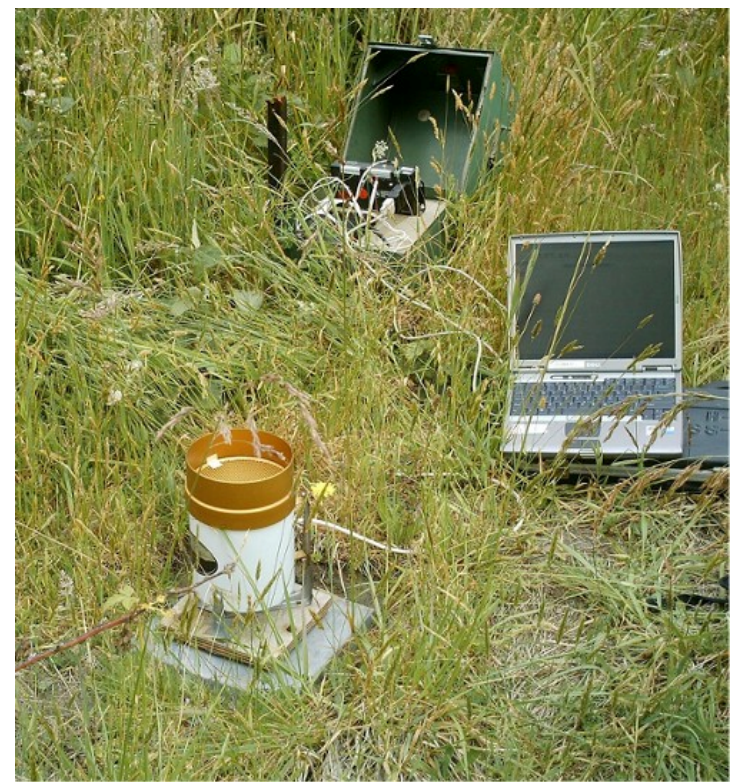

\section{Figure 4.5}

The location of the rain gauge at Site 7. Note the different type of gauge in this photograph compared to Figure 4.2 . The gauge was changed 3 months into data collection because of to vandalism to original gauge.

The main disadvantage of this type of rain gauge is that precipitation events less than the capacity of the bucket are not recorded. Also if the rain ceases before the bucket 
tips, some rainfall may be lost to evaporation (Sokolov and Chapman, 1974, Ward, 1967). During an intense precipitation event, the tipping-bucket gauge may tip multiple times per second. Approximately 0.3 of a second is required to complete a tip. Any rainfall during the movement of the central mechanism i.e. during the tipping of the bucket, is effectively 'lost' as it flows into the already full bucket (Ward, 1967, Linsley et al. 1949). This was not a problem during the current study as rainfall intensities were not this high.

The rain gauge also acts as an obstacle to the flow of wind over the ground surface. This can cause eddying and turbulence. The air flow velocity is increased, resulting in falling rain being carried past the gauge (Smith, 1992, Ward, 1967). This effect can vary with the height of the gauge and velocity of the wind, but will result in and under-estimate of precipitation (Ward, 1967). If the rim of the gauge is too close to the ground surface, in-splashing, can occur, in this case the level of precipitation is over-estimated (Ward, 1967). The height of the gauge needs to be at a comprise between these two factors, to minimise both sources of error. These errors were considered when the locating and siting each gauge. They did not adversely influence the results.

Vandalism of recording equipment is another possible source of error for this study. The rain gauge located at Site 7, on the Waikanae Golf Course, suffered extensive damage to the external housing (Figure 4.6). The exact date of the vandalism is unknown as no rainfall appeared to be lost when the data were compared to the other gauges. The gauge was replaced soon after the damage was discovered on 17th October. Figure 4.5 shows the replacement gauge. Data were downloaded from each site approximately every 4-6 weeks. 


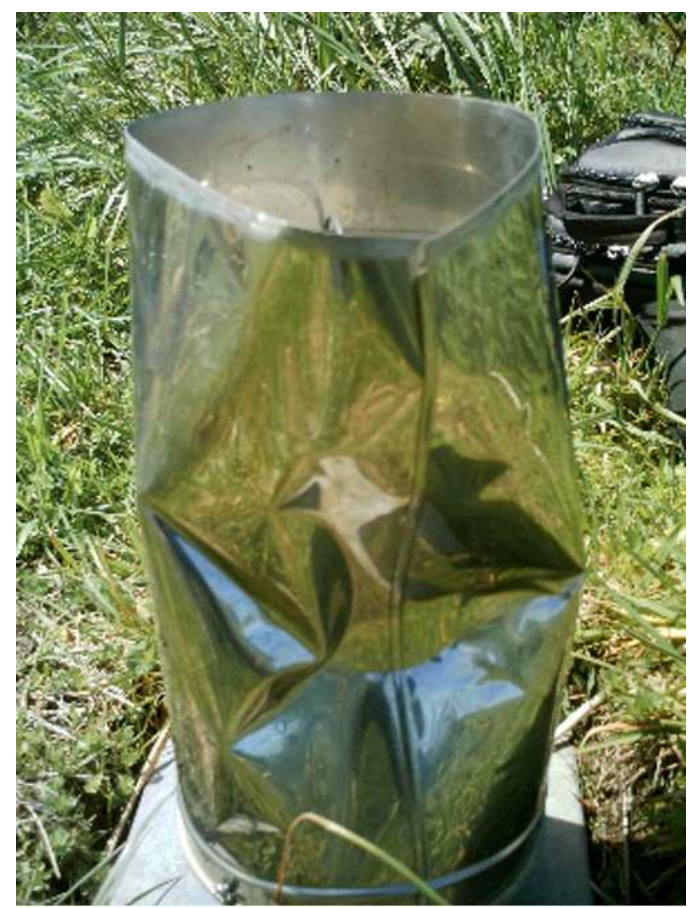

Figure 4.6

Vandalised rain gauge located at Site 7, on the edge of the Waikanae Golf Course.

\subsubsection{Evapotranspiration}

Climatic data from Paraparaumu Airport was used to calculate the potential evapotranspiration in the Te Harakiki area. The FAO Penman-Monteith (FAO PM) combination equation was used. This closely approximates grass $\mathrm{ET}_{0}$ at the location evaluated, is physically based, and explicitly incorporates both physiological and aerodynamic parameters (Allen et al. 2006). This method is the recommended standard by the Food and Agriculture Organisation (Chen et al. 2005). The method is also based on fundamental physical principles, making it universally applicable (Chen et al. 2005).

The diverse range of wetland vegetation species and the limited time available in this study, meant that the use of the reference crop equation simplified the process. Although evapotranspiration could have been calculated for each plant species within the wetland, this would have required a detailed vegetation map, and a multiple area approach. The evapotranspiration for each species, as a proportion of the total area, would then need to be calculated. The total evapotranspiration is then derived from the sum of the individual vegetation values. The Penman-Monteith equation is 
considered to be the most physical and reliable method for the calculation of evapotranspiration. It was used in studies of evapotranspiration by Favero et al. (2007), Lascano and van Bavel, (2007), Suleiman and Hoogenboom, (2007), Chen et al. (2005), and Drexler et al. (1999).

Reference evapotranspiration $\left(\mathrm{ET}_{0}\right)$ is a theoretical value; and is defined as the rate of evapotranspiration from a hypothetical reference crop with an assumed height of $0.12 \mathrm{~m}$, a fixed canopy resistance of $70 \mathrm{~s} / \mathrm{m}$, and an albedo of 0.23 (Pereira et al. 1999). The FAO Penman-Monteith method requires radiation, air temperature, air humidity and wind speed data and is derived from the following equation:

$$
\mathrm{ET}_{\circ}=\frac{0.408 \Delta\left(\mathrm{R}_{\mathrm{n}}-\mathrm{G}\right)+\gamma \frac{900}{\mathrm{~T}+273} \mathrm{u}_{2}\left(\mathrm{e}_{\mathrm{s}}-\mathrm{e}_{\mathrm{a}}\right)}{\Delta+\gamma\left(1+0.34 \mathrm{u}_{2}\right)}
$$

Where: $\quad \mathrm{ET}_{0}=$ reference evapotranspiration $\left[\mathrm{mm} \mathrm{day}^{-1}\right]$

$\mathrm{R}_{\mathrm{n}} \quad=$ net radiation at the crop surface $\left[\mathrm{MJ} \mathrm{m}^{-2}\right.$ day $\left.^{-1}\right]$

$\mathrm{G} \quad=$ soil heat flux density $\left[\mathrm{MJ} \mathrm{m}^{-2}\right.$ day $\left.^{-1}\right]$

$\mathrm{T}=$ mean daily air temperature at $2 \mathrm{~m}$ height $\left[{ }^{\circ} \mathrm{C}\right]$

$\mathrm{u}_{2} \quad=$ wind speed at $2 \mathrm{~m}$ height $\left[\mathrm{m} \mathrm{s}^{-1}\right]$

$\mathrm{e}_{\mathrm{s}} \quad=$ saturation vapour pressure $[\mathrm{kPa}]$

$\mathrm{e}_{\mathrm{a}} \quad=$ actual vapour pressure $[\mathrm{kPa}]$

$\mathrm{e}_{\mathrm{s}}-\mathrm{e}_{\mathrm{a}}=$ saturation pressure deficit $[\mathrm{kPa}]$

$\Delta \quad=$ slope vapour pressure curve $[\mathrm{kPa}]$

$\gamma \quad=$ psychrometric constant $\left[\mathrm{kPa}^{\circ} \mathrm{C}^{-1}\right]$

Source: Chen et al, (2005).

Psychrometric constant $(\gamma)$

To calculate $\mathrm{ET}_{0}$ various atmospheric and meteorological parameters must first be calculated. To derive the psychrometric constant it is necessary to first calculate atmospheric pressure. This is the pressure exerted by the earth's atmosphere, and it can be calculated by

$$
P=101.3\left(\frac{293-0.0065 z}{293}\right)^{5.26}
$$


Where: $\quad \mathrm{P}=$ atmospheric pressure $[\mathrm{kPa}]$

$\mathrm{Z}=$ elevation above sea level $[\mathrm{m}]$

Source: Allen et al. (2006).

The value of $\mathrm{P}$ as a function of altitude was taken from Allen et al. (2006) and can be found in Appendix 1.

The latent heat of vaporisation $(\lambda)$ (also required to calculate the psychrometric constant) is the energy required to change a unit mass of water from liquid to vapour at a constant pressure and constant temperature. As $\lambda$ only varies slightly over normal temperature ranges, a single value of $2.45 \mathrm{MJ} \mathrm{kg}^{-1}$ is used in the FAO PenmanMonteith equation (FAO PM). This equates to the latent heat for an air temperature of $20^{\circ} \mathrm{C}$ (Allen et al. 2006).

The psychrometric constant $(\gamma)$ is calculated from:

$$
\gamma=\frac{\mathrm{c}_{\mathrm{p}} \mathrm{P}}{\varepsilon \lambda}=0.665 \times 10^{-3} \mathrm{P}
$$

Where: $\gamma=$ psychrometric constant $\left[\mathrm{kPa}{ }^{\circ} \mathrm{C}^{-1}\right]$

$\mathrm{P}=$ atmospheric pressure $[\mathrm{kPa}]$

$\lambda=$ Latent heat of vapourisation, $2.45\left[\mathrm{MJ} \mathrm{kg}^{-1}\right]$

$\mathrm{c}_{\mathrm{p}}=$ specific heat at a constant pressure, $1.01310^{-3}\left[\mathrm{MJ} \mathrm{kg}^{-1}{ }^{\circ} \mathrm{C}^{-1}\right]$

$\varepsilon=$ ratio of molecular weight of water vapour/dry air $=0.622$

Source: Allen et al. (2006).

The specific heat at a constant pressure $\left(c_{p}\right)$ is the amount of energy required to increase the temperature of a unit mass of air by one degree. The value depends on the composition of the air. For average conditions, a $\mathrm{c}_{\mathrm{p}}$ of $1.01310^{-3}\left[\mathrm{MJ} \mathrm{kg}^{-1}{ }^{\circ} \mathrm{C}^{-1}\right]$ can be used. The value of the psychrometric constant as a function of altitude can be found in Appendix 1 (Allen et al. 2006).

Mean Temperature $\left(T_{\text {mean }}\right)$

Heat emitted by the earth and solar radiation that is absorbed by the atmosphere both increase air temperature. The sensible heat of this air transfers energy to vegetation. This exerts a controlling influence on evapotranspiration rates. Evapotranspiration is greater on warm, sunny days than on cool, cloudy days (Allen et al. 2006). 
Both minimum and maximum air temperatures are recorded at the Paraparaumu Airport. The non-linearity of humidity data in the FAO PM equation means that the vapour pressure for a period should be calculated as the mean of the daily maximum and minimum air temperatures of the period. The mean air temperature $\left(\mathrm{T}_{\text {mean }}\right)$ is used to calculate the slope of the saturation vapour pressure curves $(\Delta)$, and the mean air density $\left(\mathrm{P}_{\mathrm{a}}\right)$ (Allen et al. 2006).

$$
\mathrm{T}_{\text {mean }}=\frac{\mathrm{T}_{\max }+\mathrm{T}_{\min }}{2}
$$

Relative Humidity $(R H)$

Solar radiation is the main energy source for the vaporisation of water. The difference between the water vapour pressure at the evaporating surface, and that of the surrounding air, controls the rate of water vapour removal. In a humid environment, the air is already close to saturation. Therefore, less saturated air can be added before the evapotranspiration rate is lowered (Allen et al. 2006). Relative humidity was recorded by psychrometers which measure the difference between wet and dry bulb thermometers. The bulb of the dry thermometer measures air temperature. The wet bulb of the thermometer is covered with a constantly saturated wick. Evaporation of water from the wick lowers the temperature (Allen et al. 2006). The relative humidity $(\mathrm{RH})$ is an expression of the degree of saturation of the air. It is a ratio of the actual $\left(\mathrm{e}_{\mathrm{a}}\right)$ to the saturated $\left(\mathrm{e}^{\circ}\right)$ vapour pressure at the same temperature $(\mathrm{T})$ :

$$
\mathrm{RH}=100 \frac{\mathrm{e}_{\mathrm{a}}}{\mathrm{e}^{\mathrm{o}}(\mathrm{T})}
$$

$\mathrm{RH}$ is therefore the ratio of the amount of water in the ambient air to the maximum amount it could hold at the same temperature. It is commonly given as a percentage. Actual vapour pressure tends to be constant throughout the day. However, RH fluctuates between a maximum near sunrise and a minimum in the early afternoon. Variation in relative humidity is caused by the saturation vapour pressure being determined by the air temperature. As air temperature changes during the day, the relative humidity also changes substantially (Allen et al. 2006). 
Mean saturation vapour pressure $\left(e_{s}\right)$

As saturation vapour pressure is dependant upon air temperature, it can be derived from air temperature data. This relationship is expressed as:

$$
\mathrm{e}^{\circ}(\mathrm{T})=0.6108 \exp \left[\frac{17.27 \mathrm{~T}}{\mathrm{~T}+237.3}\right]
$$

Where:

$\mathrm{e}^{\circ}(\mathrm{T})=$ saturation vapour pressure at air the temperature $\mathrm{T}[\mathrm{kPa}]$

$\mathrm{T}=$ air temperature $\left[{ }^{\circ} \mathrm{C}\right]$

$\exp 2.7183$ (base of natural logarithm) raised to the power Source: Allen et al. (2006).

Because of the non-linearity of the equation, using mean air temperature can underestimate evapotranspiration. The mean saturation vapour pressure should therefore be estimated as the mean of the saturation vapour pressure at the daily maximum and the daily minimum air temperature. Values for $\mathrm{e}^{\circ}(\mathrm{T})$ were taken from Allen et al. (2006) and can be found in Appendix 1.

$$
\mathrm{e}_{\mathrm{s}}=\frac{\mathrm{e}^{\circ}\left(\mathrm{T}_{\max }\right)+\mathrm{e}^{\circ}\left(\mathrm{T}_{\min }\right)}{2}
$$

Slope of the saturation vapour pressure curve (4)

The slope of the saturation vapour pressure curve is given by:

$$
\Delta=\frac{4098\left[0.6108 \exp \left(\frac{17.27 \mathrm{~T}}{\mathrm{~T}+237.3}\right)\right]}{(\mathrm{T}+237.3)^{2}}
$$

Where:

$$
\begin{aligned}
& \Delta=\text { slope of the saturation vapour curve at air temperature } \mathrm{T}\left[\mathrm{kPa}{ }^{\circ} \mathrm{C}\right] \\
& \mathrm{T}=\text { air temperature }\left[{ }^{\circ} \mathrm{C}\right] \\
& \text { Exp[... } 2.7183 \text { (base of natural logarithm) raised to the power }[\ldots] \\
& \text { Source: Allen et al. }(2006) .
\end{aligned}
$$

Values for $\Delta$ at different temperatures were taken from Allen et al. (2006) and are given in Appendix 1. 
Actual Vapour pressure derived from relative humidity data $\left(\mathrm{RH}_{\text {mean }}\right)$

$$
e_{a}=\frac{R H_{\text {mean }}}{100}\left[\frac{e^{\circ}\left(T_{\text {max }}\right)+e^{\circ}\left(T_{\text {min }}\right)}{2}\right]
$$

Vapour pressure deficit is the difference between the saturation $\left(e_{s}\right)$ and actual $\left(e_{a}\right)$ vapour pressure for a given time period.

$$
\left(e_{s}-e_{a}\right)
$$

The process of evapotranspiration is therefore largely governed by the amount of energy available to convert water from a liquid to gas. Solar radiation is the largest energy source that can vaporise water (Allen et al. 2006). The amount of radiation that can reach an evaporating surface depends on position and the time of year. Potential radiation differs at various latitudes, and in different seasons, because of changes in the position of the sun (Allen et al. 2006). The actual amount of radiation that reaches the earth surface is dependant on the cloud cover and air turbulence. Part of the solar energy is used to heat up the atmosphere and the soil profile (Allen et al. 2006).

The average daily net radiation expressed in megajoules per square metre per day [MJ $\mathrm{m}^{-3}$ day $^{-1}$ ] is required to calculate evapotranspiration. This can be calculated from the (average) daily actual duration of bright sunshine (hours per day) measured with a sunshine recorder (Allen et al. 2006).

Radiation striking a surface perpendicular to the suns' rays at the top of the earth's atmosphere is the solar constant, and is about $0.082 \mathrm{MJ} \mathrm{m}^{-2} \mathrm{~min}^{-1}$ (Allen et al. 2006). The local intensity of radiation is determined by the angle between the direction of the sun's ray and the normal to the surface of the earth's atmosphere. This angle changes with the seasons and time of day. It is also different for different latitudes (Allen et al. 2006). Extraterrestrial radiation for daily periods $\left(R_{a}\right)$ is a function of latitude, date, and time of day. It can be estimated using the solar constant, solar declination and the time of year: 


$$
\mathrm{R}_{\mathrm{a}}=\frac{24(60)}{\pi} \mathrm{G}_{\mathrm{sC}} \mathrm{d}_{\mathrm{r}}\left[\omega_{\mathrm{s}} \sin (\varphi) \sin (\delta)+\cos (\varphi) \cos (\delta) \sin \left(\omega_{\mathrm{s}}\right)\right]
$$

Where: $\quad \mathrm{R}_{\mathrm{a}}=$ extraterrestrial radiation $\left[\mathrm{MJ} \mathrm{m}^{-2} \mathrm{day}^{-1}\right]$

$\mathrm{G}_{\mathrm{sc}}=$ solar constant $=0.0820 \mathrm{MJ} \mathrm{m}^{-2} \mathrm{~min}^{-1}$

$\mathrm{d}_{\mathrm{r}}=$ inverse relative distance Earth-Sun (Equation 4.13)

$\omega_{\mathrm{s}}=$ sunset hour angle (Equation 4.15) [radians]

$\varphi=$ latitude [radians] (Equation 4.12)

$\delta=$ solar declination (Equation 4.14) [radians]

Source: Allen et al. (2006).

The latitude, $\varphi$, is expressed in radians and is positive for the northern hemisphere and negative for the southern hemisphere. The conversion of decimal degrees to radians is given below:

$$
[\text { Radians }]=\frac{\pi}{180}[\text { decimal degrees }]
$$

The inverse relative distance Earth - Sun, $\mathrm{d}_{\mathrm{r}}$ and the solar declination, $(\delta)$ are given by the following two equations:

$$
\begin{array}{r}
d_{r}=1+0.033 \cos \left(\frac{2 \pi}{365} \mathrm{~J}\right) \\
\delta=0.409 \sin \left(\frac{2 \pi}{365} \mathrm{~J}-1.39\right)
\end{array}
$$

Where $\mathrm{J}$ is the Jadian number of the day in the year between 1 (1 January) and 365 (or 366 in a leap year) (December 31). (Values for J are given in Appendix 1).

Sunset hour angle $\left(\omega_{s}\right)$

$$
\omega_{s}=\arccos [-\tan (\varphi) \tan (\delta)]
$$

Daylight hours (N)

$$
\mathrm{N}=\frac{24}{\pi} \omega_{\mathrm{s}}
$$

Of the radiation that penetrates the atmosphere some is, reflected, scattered, or absorbed by atmospheric gases, dust and clouds. The amount that reaches the horizontal plane is the solar radiation $\left(\mathrm{R}_{\mathrm{s}}\right)$. It is also referred to as shortwave radiation (Allen et al. 2006). If solar radiation is not recorded, it can be calculated using the 
Angstrom Formula. This relates solar radiation to extraterrestrial radiation and relative sunshine duration.

$$
R_{s}=\left(a_{s}+b_{s} \frac{n}{N}\right) R_{a}
$$

Where: $\mathrm{R}_{\mathrm{S}} \quad=$ solar or shortwave radiation $\left[\mathrm{MJ} \mathrm{m}^{-2}\right.$ day $\left.^{-1}\right]$

$\mathrm{n} \quad=$ actual duration of sunshine [hour]

$\mathrm{N} \quad$ = maximum possible duration of sunshine or daylight hours [hours]

$\mathrm{n} / \mathrm{N}=$ relative sunshine duration (-)

$\mathrm{R}_{\mathrm{a}} \quad=$ extraterrestrial radiation $\left[\mathrm{MJ} \mathrm{\textrm {m } ^ { - 2 }}\right.$ day $^{-1}$ ]

$\mathrm{a}_{\mathrm{s}} \quad=$ regression constant, expressing the fraction of the extraterrestrial radiation reaching the earth on overcast days $(n=0)$

$a_{s}+b_{s}=$ fraction of extraterrestrial radiation reaching the earth on clear days $(\mathrm{n}=\mathrm{N})$

Source: Allen et al. (2006).

Depending on atmospheric conditions (humidity, dust) and solar declination (latitude and month) the Angstrom values $a_{s}$ and $b_{s}$ will vary. When no calibration is carried out the values $a_{s}=0.25$ and $b_{s}=0.50$ are recommended. These were used in the calculations in this study.

Clear sky solar radiation $\left(R_{\text {so }}\right)$

$$
R_{50}=\left(a_{5}+b_{5}\right) R_{a}
$$

Where: $\mathrm{R}_{\mathrm{so}} \quad=$ clear sky solar radiation $\left[\mathrm{MJ} \mathrm{m}^{-2}\right.$ day $\left.^{-1}\right]$

$a_{s}+b_{s}=$ fraction of extraterrestrial radiation reaching the earth on clear days $(\mathrm{n}=\mathrm{N})$

Source: Allen et al. (2006).

As values for $a_{s}$ and $b_{s}$ were not available, the following equation was used:

$$
R_{\text {so }}=\left(0.75+210^{-5} z\right) R_{a}
$$

Where: $\mathrm{z}=$ station elevation above sea level $[\mathrm{m}]$

Source: Allen et al. (2006).

Relative shortwave radiation is the ratio of solar radiation $\left(\mathrm{R}_{\mathrm{s}}\right)$ to the clear sky solar radiation $\left(\mathrm{R}_{\mathrm{so}}\right)$. $\mathrm{R}_{\mathrm{s}}$ is the solar radiation that reaches the earth's surface in a given period. $R_{\text {so }}$ is the same amount of solar radiation that would reach the earth's surface on a cloudless day. Relative shortwave radiation is a way to express the cloudiness of the atmosphere. The clearer the sky the larger the ratio (Allen et al. 2006). 
Relative shortwave radiation

$$
\left(\mathrm{R}_{\mathrm{S}} / \mathrm{R}_{\mathrm{so}}\right)
$$

A large amount of solar radiation reaching the earth's surface is reflected. The proportion, $\alpha$, of the solar radiation reflected by the earth's surface is known as albedo. Albedo is highly variable for different land surfaces. For the green grass reference crop used in the FAO PM equation, $\alpha$ is given a value of 0.23 (Allen et al. 2006).

Net solar or net shortwave radiation $\left(\mathrm{R}_{\mathrm{ns}}\right)$ is the fraction of solar radiation $\left(\mathrm{R}_{\mathrm{s}}\right)$ that is not reflected.

$$
\mathrm{R}_{\mathrm{ns}}=(1-\alpha) \mathrm{R}_{\mathrm{s}}
$$

Where: $\mathrm{R}_{\mathrm{ns}}=$ net solar or net shortwave radiation $\left[\mathrm{MJ} \mathrm{m}{ }^{-2}\right.$ day $\left.^{-1}\right]$

$\alpha=$ albedo or canopy reflection coefficient, which is 0.23 for the hypothetical grass reference crop

$\mathrm{R}_{\mathrm{S}}=$ the incoming solar radiation $\left[\mathrm{MJ} \mathrm{m}{ }^{-2} \mathrm{day}^{-1}\right]$

Source: Allen et al. (2006).

Solar radiation that is absorbed by the earth is converted into heat energy. The earth emits radiative energy (long wave) with longer wave lengths than those from the sun. Longwave radiation is either absorbed by the atmosphere or lost into space. The longwave radiation that is absorbed by the atmosphere increases air temperature. The earth's surface both receives and emits longwave radiation. The difference between the incoming and outgoing radiation is the net longwave radiation $\left(\mathrm{R}_{n l}\right)$. If outgoing radiation is greater than the incoming; $\mathrm{R}_{\mathrm{nl}}$ represents an energy loss and vice versa (Allen et al. 2006).

The Stefan-Boltzmann law shows the relationship between the rate of longwave energy emission, and absolute temperature of the earth's surface raised to the fourth power. Water vapour, dust and carbon dioxide are all both absorbers and emitters of longwave radiation. Humidity and cloudiness are important in this calculation, and the Stefan-Boltzmann law is corrected for these two factors (Allen et al.2006). It is assumed that the concentrations of all other absorbers are constant: 


$$
\mathrm{R}_{\mathrm{nl}}=\sigma\left[\frac{\mathrm{T}_{\max , \mathrm{K}^{4}+\mathrm{T}_{\min , \mathrm{K}}}}{2}\right]\left(0.34-0.14 \sqrt{\mathrm{e}_{\mathrm{a}}}\right)\left(1.35 \frac{\mathrm{R}_{\mathrm{s}}}{\mathrm{R}_{\mathrm{s0}}}-0.35\right)
$$

Where: $\mathrm{R}_{\mathrm{nl}} \quad$ = net outgoing long wave radiation $\left[\mathrm{MJ} \mathrm{m}^{-2}\right.$ day $\left.^{-1}\right]$

$\sigma \quad=$ Sefan-Boltzmann constant $\left[4.90310^{-9} \mathrm{MJ} \mathrm{K}^{-4} \mathrm{~m}^{-2} \mathrm{day}^{-1}\right]$

$\mathrm{T}_{\max }, \mathrm{K}=$ maximum absolute temperature during the 24-hour period $\left[\mathrm{K}={ }^{\circ} \mathrm{C}\right.$ $+273.16]$

$\mathrm{T}_{\min }, \mathrm{K}=$ minimum absolute temperature during the 24 -hour period $\left[\mathrm{K}={ }^{\circ} \mathrm{C}+\right.$ 273.16]

$\mathrm{R}_{\mathrm{S}} / \mathrm{R}_{\mathrm{so}}=$ relative shortwave radiation (limited to $\leq 1.0$ )

$\mathrm{R}_{\mathrm{S}} \quad=$ measured or calculated (equation 4.17) solar radiation $\left(\mathrm{MJ} \mathrm{m}^{-2} \mathrm{day}^{-1}\right)$

$\mathrm{R}_{\mathrm{so}} \quad=$ Calculated (Equation 4.19) clear sky radiation $\left[\mathrm{MJ} \mathrm{m}{ }^{-2}\right.$ day $\left.^{-1}\right]$ Source: Allen et al. (2006).

The effect of cloudiness is expressed as $\left(1.35 R_{s} / R_{s o}-0.35\right) . R_{s}$ decreases as cloudiness increases. The term $\left(0.34-0.14 \sqrt{ } \mathrm{e}_{\mathrm{a}}\right)$ is the correction for humidity and is smaller as humidity increases. (See Appendix 1 for values of $\sigma \mathrm{T}_{\mathrm{K}}{ }^{4}$ at different air temperatures (Allen et al. 2006)).

Net Radiation $\left(\mathrm{R}_{\mathrm{n}}\right)$ is the difference between the incoming and outgoing radiation; including both long and shortwave radiation. It represents the balance between the incoming shortwave radiation $\left(\mathrm{R}_{\mathrm{ns}}\right)$ and the net outgoing longwave radiation $\left(\mathrm{R}_{\mathrm{n}}\right)$ (Allen et al. 2006).

$$
R_{n}=R_{n s}-R_{n l}
$$

Soil Heat Flux $(G)$ is the energy that is used in heating the soil. $(G)$ is positive when the soil is warming and negative when it is cooling. The soil heat flux is small compared to $\mathrm{R}_{\mathrm{n}}$, but the amount of energy lost or gained by the soil should be added or subtracted from $\mathrm{R}_{\mathrm{n}}$ when calculating evapotranspiration (Allen et al. 2006). The soil heat capacity is related to the mineral and water content of the soil profile. Because soil temperature lags behind air temperature, the average temperature for a period should be used to assess the daily soil heat flux. Daily soil heat flux was assumed to be 0 . This is based on the recommendations from the FAO PM equation for daily $\mathrm{ET}_{0}$ calculations as used by Suleiman and Hoogenboom (2007). 


$$
\mathrm{G}=\mathrm{c}_{\mathrm{s}} \frac{\mathrm{T}_{\mathrm{i}}+\mathrm{T}_{\mathrm{i}-\mathrm{l}}}{\Delta \mathrm{t}} \Delta \mathrm{z}
$$

Where: $\mathrm{G}=$ soil heat flux $\left[\mathrm{MJ} \mathrm{m}^{-2} \mathrm{day}^{-1}\right]$

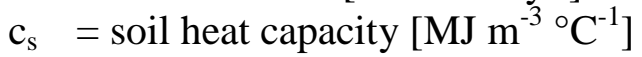

$\mathrm{T}_{\mathrm{i}}=$ air temperature at time $\mathrm{i}\left[{ }^{\circ} \mathrm{C}\right]$

$\mathrm{T}_{\mathrm{i}-1}=$ air temperature at time $\mathrm{i}-1\left[{ }^{\circ} \mathrm{C}\right]$

$\Delta \mathrm{t}=$ length of time interval [day]

$\Delta \mathrm{z}=$ effective soil depth $[\mathrm{m}]$

Source: Allen et al. (2006).

Vapour removal in the air depends on wind and air turbulence which transfers large amounts of air over the evaporating surface (Allen et al. 2006). The air above an evaporating surface slowly becomes saturated with water vapour. If this air is not continuously replaced with drier air, the evapotranspiration rate decreases (Allen et al. 2006). Wind speed is therefore required for the calculation of evapotranspiration.

The wind speed at different heights above the ground surface varies because of friction. Anemometers are positioned at a standard height. For the calculation of evapotranspiration, wind speed $\left(\mathrm{m} \mathrm{s}^{-1}\right)$ is measured $2 \mathrm{~m}$ above the ground surface. As wind speed varies over time, it is necessary to express it as an average over a given time period (Allen et al. 2006).

If wind speed has been measured at heights other than $2 \mathrm{~m}$ above the ground surface, they can be standardised using the following equation:

$$
\mathrm{u}_{2}=\mathrm{u}_{\mathrm{z}} \frac{4.87}{\ln (67.8 \mathrm{z}-5.42)}
$$

Where: $\mathrm{u}_{2}=$ wind speed at $2 \mathrm{~m}$ above ground surface $\left[\mathrm{m} \mathrm{s}^{-1}\right]$

$\mathrm{u}_{\mathrm{z}}=$ measured wind speed at $\mathrm{z} \mathrm{m}$ above ground surface $\left[\mathrm{m} \mathrm{s}^{-1}\right]$

$\mathrm{z}=$ height of measurement above ground surface $[\mathrm{m}]$ Source: Allen et al. (2006).

Reference evapotranspiration was estimated by deriving the required values from the above equations and carrying these through to Equation 4.1. 


\section{4: Surface water}

\subsubsection{Staff Gauges}

Staff gauges were installed at three sites along the Ngarara Stream (refer to Figure 4.1). A staff gauge is a graduated scale set into the water body, so that part of the gauge will be submersed at all stages, and the level of the water surface on the scale can easily be observed and manually recorded (Ward, 1967, Linsley et al. 1949). The gauge also needs to be attached to a solid structure or adequately supported to ensure there is no change in datum as a result of settling of sediment (Linsley et al. 1949). The staff gauges at each site were securely attached to warratahs, using stainless steel u-bolts. The warratahs were driven into the sediment of the stream bed.

As the staff gauges needed to be removed from the water on each site visit to download the automated water level record, a datum was marked on each staff plate. This ensured that the gauge was returned to the same position relative to the water column. Staff gauge readings were taken from each site, on each site visit, to check the accuracy of the data recorded by the pressure transducers.

Site 3 (Figure 4.7) was located where the Ngarara Stream enters the wetland. Greater Wellington also have a staff gauge at this site, (on the opposite side of the culvert). The water level of the stream is recorded manually every six weeks by Council staff.

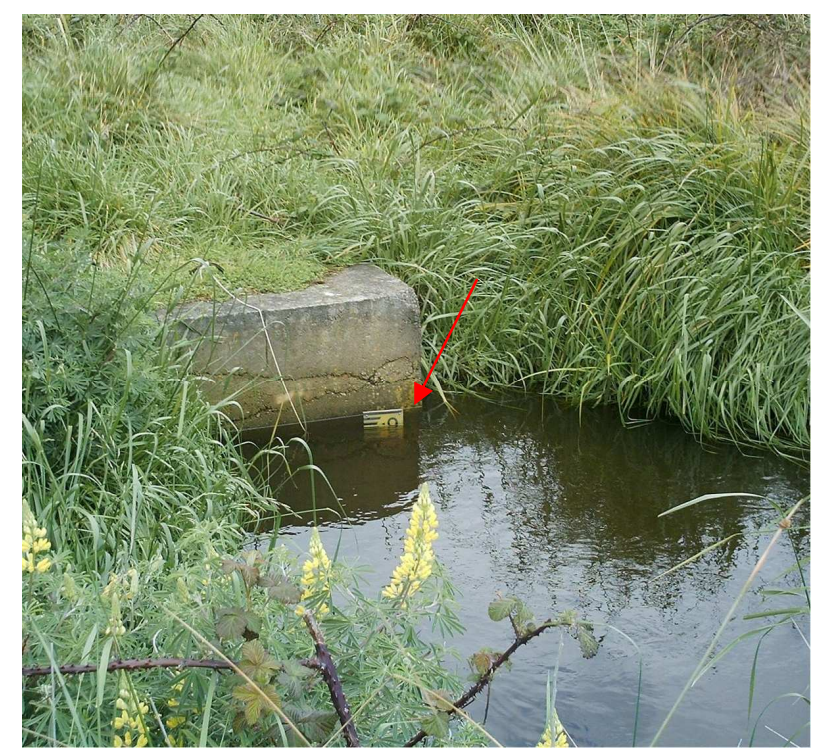

Figure 4.7 Site 3. The staff gauge (with miniTROLL attached) was located at a concrete culvert on Ngarara Stream where it enters the wetland system. 
Site 5 (Figure 4.8) was located approximately 490m downstream from Site 3. It is a relatively open section of the wetland, where water from the stream ponds in the wetland during the wetter parts of the year or during flood events.

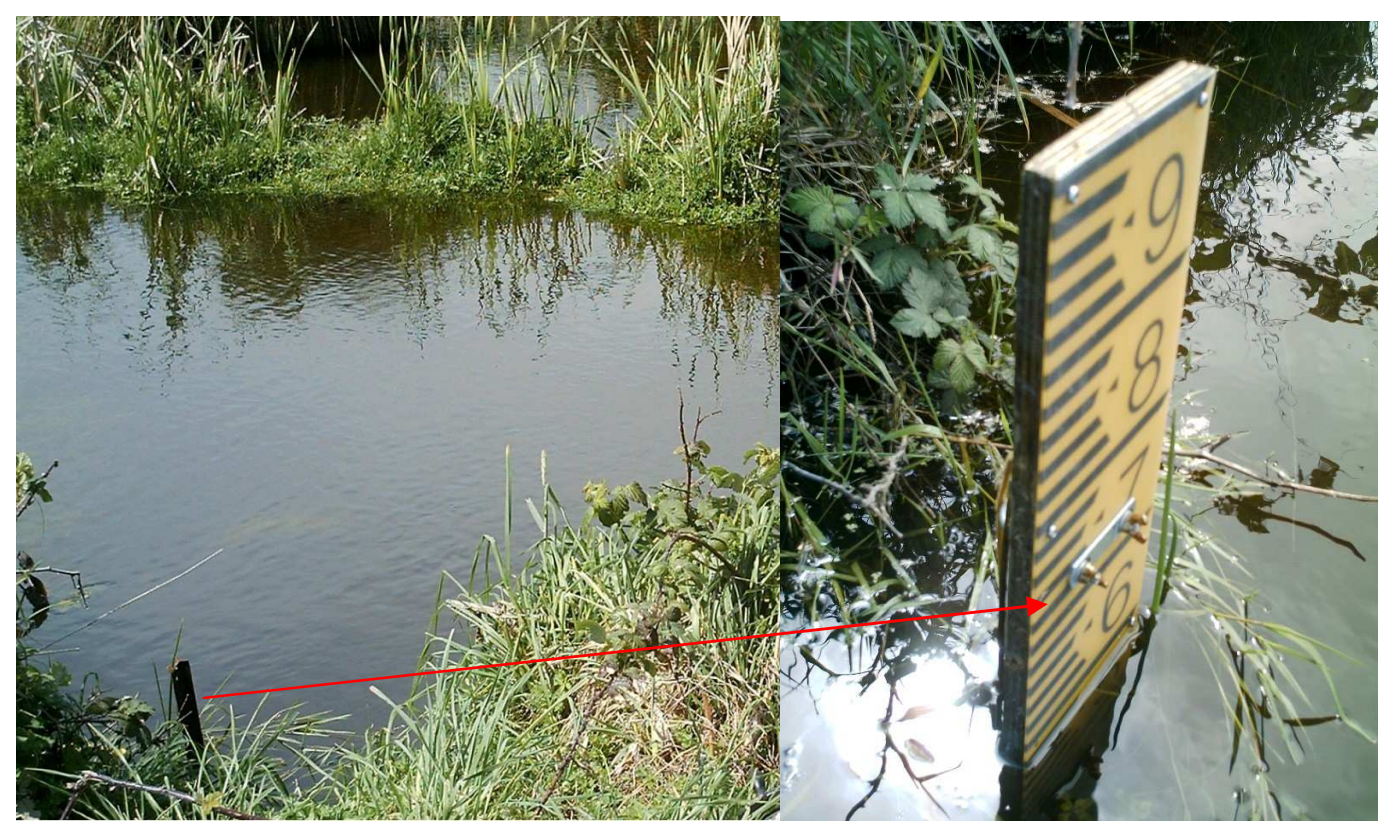

Figure 4.8 The staff gauge (with miniTROLL attached) at Site 5. This is one of the locations along Ngarara Stream where the water from the stream ponds within the wetland.

The water level recorder at Site 7 was located approximately $840 \mathrm{~m}$ downstream from Site 5 (Figure 4.9). This is approximately $73 \mathrm{~m}$ outside of the wetland boundary. It is located on the Waikanae Golf Course; under the bridge by the $5^{\text {th }}$ hole.

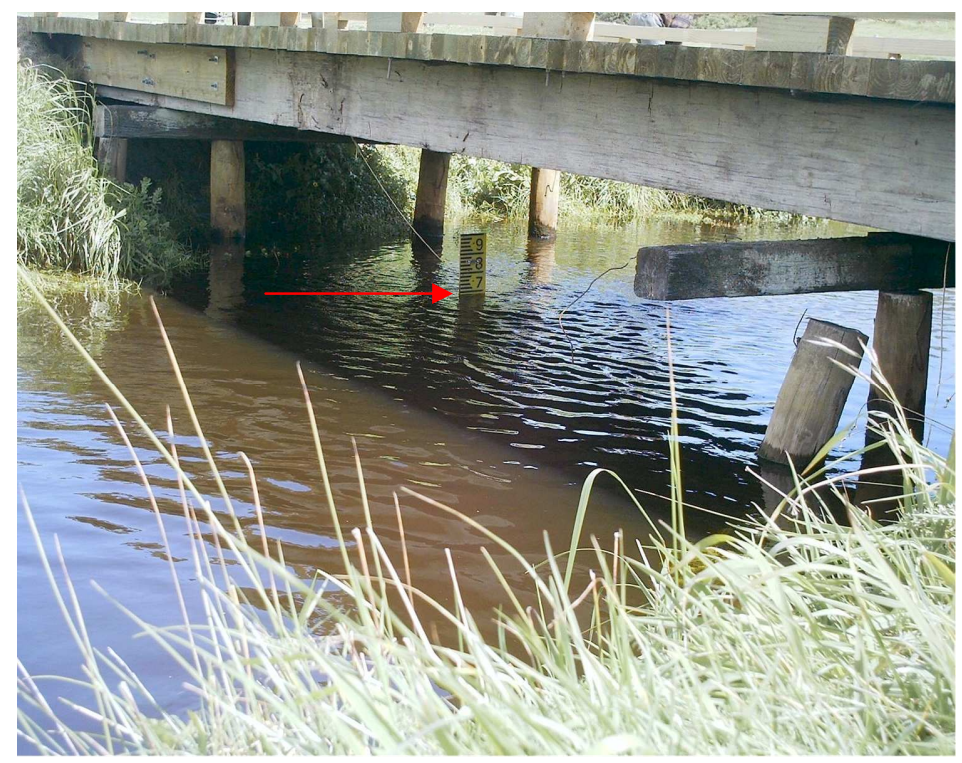

Figure 4.9 The staff gauge (with miniTROLL attached) located under the bridge at the Waikanae Golf Course. This is $73 \mathrm{~m}$ downstream from where the Ngarara Stream emerges from the wetland. 


\subsubsection{Water level recorders}

Water level measurements were made continuously using a pressure transducer and datalogger. The data recorded were used in the water balance calculation, and for the assessment of the interactions between the surface and groundwater systems. A combined pressure transducer and data logger was used in the form of miniTROLL (model SSP-100) from In-Situ Inc. The miniTROLL housing contains a pressure sensor, temperature sensor, real-time clock, back-up capacitor, microprocessor, and up to $1 \mathrm{MB}$ of data storage memory (In-Situ Inc, 2004). The internal power model miniTROLL was used.

Fluctuations in water level result in a corresponding change in the weight of water above the miniTROLL. This varies the electrical resistance of the device (Brassington, 2007). The loggers were programmed to record the water level every five minutes. A small electrical current is passed through the transducer, and the variation in voltage is recorded by the logger. This information is converted to a water level recording by the data logger (Brassington, 2007).

At all three surface water monitoring sites a miniTROLL was securely attached with brackets to the staff gauge (Figure 4.10). A small platform was screwed onto the front of each staff plate, to ensure that the miniTROLL could be returned to exactly the same position after each site visit. Data were collected from the dataloggers approximately every $4-6$ weeks 


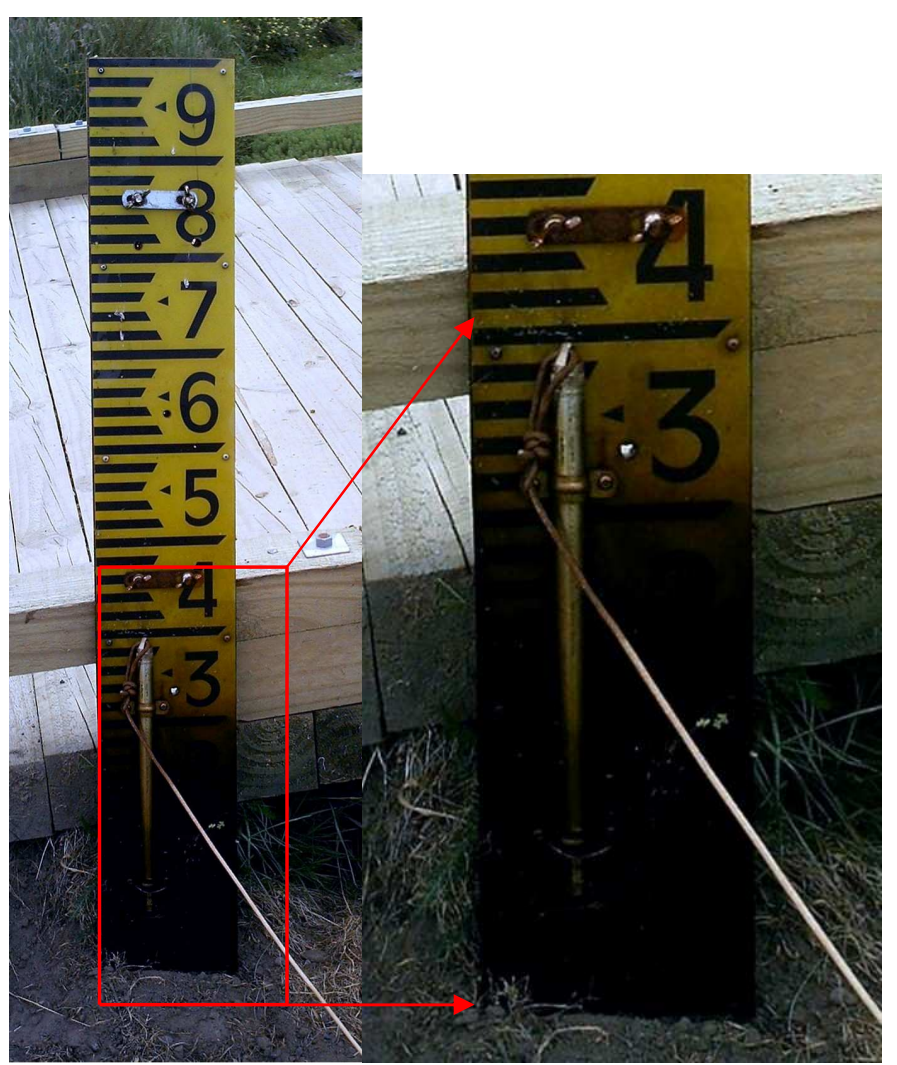

Figure 4.10 Staff gauge (from Site 7) with miniTROLL attached, iron staining within the wetland has stained the plate of the gauge since it was installed.

\subsubsection{Tidal Data}

The surface water recorder at Site 7 (Figure 4.1) appeared to be influenced by factors other than precipitation that caused 'peaks' in stream flow. When compared with the other surface water sites, the flood peaks caused by rainfall correlated well. There were other peaks and troughs however, on top of the rainfall generated record. The recurring nature of the peaks (on an approximate $12 \mathrm{hr}$ cycle) indicated that the lower section of the stream was influenced by tides

To assess whether this was indeed the case tidal data derived from Port Taranaki were used to predict the tides at the Waikanae River mouth. As a secondary port, tidal data are routinely calculated from the tide heights and timing at the standard port (Port Taranaki). The heights and times of high and low tides from Port Taranaki, along with the mean sea level (MSL), mean high water springs (MHWS) and mean low water springs (MLWS) were used to estimate the tides for Waikanae. The MSL, MHWS an MLWS for the secondary port are also needed. These data are not available for 
Waikanae, so the values from Kapiti Island were applied. Using these data, and Figure 4.11, daily tidal information was calculated.

To calculate the timing difference of tides from the standard to secondary port the 'tide timing difference' (LINZ, Appendix 2) is added to the standard port time. In the case of Waikanae River mouth, high tide occurs 8 minutes after Port Taranaki and low tides occur 4 minutes after. Therefore, 8 minutes was added to all the high tide tidal times given and 4 minutes to all the low tide times.

\begin{tabular}{|c|c|c|c|c|c|c|c|c|}
\hline \multirow{2}{*}{$\begin{array}{l}\text { Standard } \\
\text { Port Data }\end{array}$} & \multicolumn{2}{|c|}{ (1) Times } & \multicolumn{2}{|c|}{ (2) Heights } & \multirow[t]{2}{*}{ (3) MSL } & \multicolumn{2}{|c|}{ (4) Levels } & \multirow{2}{*}{$\begin{array}{l}\text { (5) Levels } \\
\text { Range } \\
\text { MHWS-MLWS }\end{array}$} \\
\hline & HW & LW & HW & LW & & MHWS & MLWS & \\
\hline \multicolumn{3}{|c|}{$\begin{array}{l}\text { (6) Predicted Height - MSL } \\
\text { (2) - (3) }\end{array}$} & & & & & & \\
\hline \multirow{2}{*}{$\begin{array}{l}\text { Secondary } \\
\text { Port Data }\end{array}$} & \multicolumn{2}{|c|}{ (7) Time Diff } & & & \multirow[t]{2}{*}{ (8) MSL } & \multicolumn{2}{|c|}{ (9) Levels } & $\begin{array}{l}\text { (10) Levels } \\
\text { Range }\end{array}$ \\
\hline & \multicolumn{2}{|l|}{ HW } & & & & MHWs & MLWS & MHWS- MLWS \\
\hline \multicolumn{3}{|c|}{$\begin{array}{l}\text { (12) Calculations } \\
\text { (6) } \mathrm{x}(11)\end{array}$} & & & & & & $\begin{array}{l}\text { (11) Range } \\
\text { Ratio } \\
(10) /(5)\end{array}$ \\
\hline \multirow{3}{*}{$\begin{array}{c}\text { Secondary } \\
\text { Port } \\
\text { Results }\end{array}$} & \multicolumn{2}{|c|}{$\begin{array}{l}\text { (13) Times } \\
\text { (1) }+(7)\end{array}$} & \multicolumn{2}{|c|}{$\begin{array}{l}\text { (14) Heights } \\
\text { (8) + (12) }\end{array}$} & & & & \\
\hline & HW & LW & HW & LW & & & & \\
\hline & & & & & & & & \\
\hline
\end{tabular}

Figure 4.11 Calculation table for secondary port tidal data. (Source: LINZ, 2007.)

\section{5: Groundwater}

The basic device for measuring the hydraulic head of an aquifer is a tube or pipe in which the elevation of a water level can be determined (Freeze and Cherry, 1979). In field measurements a piezometer is used. A piezometer must be: sealed along its length; be open to water flow at the bottom, and the atmosphere at the top (Freeze and 
Cherry, 1979). The intake is designed to allow the inflow of water but not the sand that makes up the geologic formation in the area.

There are three shallow groundwater piezometers installed around Te Harakiki. These are at Sites 1, 2 and 6 (Figure 4.1). The piezometers were installed on April $12^{\text {th }} 2002$ for a study by Phreatos Groundwater Consulting. The location of the piezometers was chosen to provide good spatial coverage of the wetland, and complement the data from the KCDC piezometers near the oxidation ponds (Phreatos, 2002). The wells were drilled to a depth of 6 metres within fine dune sand, and completed with a 50mm diameter PVC tube and a $0.5 \mathrm{~m}$ length of slotted screen covered with a filter sock (Phreatos, 2002). The piezometers are part of the GW groundwater monitoring programme. Up until November 2005 all the sites were manually recorded by a GW staff member, using a water level dipper, every six weeks. Sites 2 and 6 are still read manually by GW. The groundwater level data recorded was included in the water balance calculation and in the assessment of the interactions between the surface and groundwater systems.

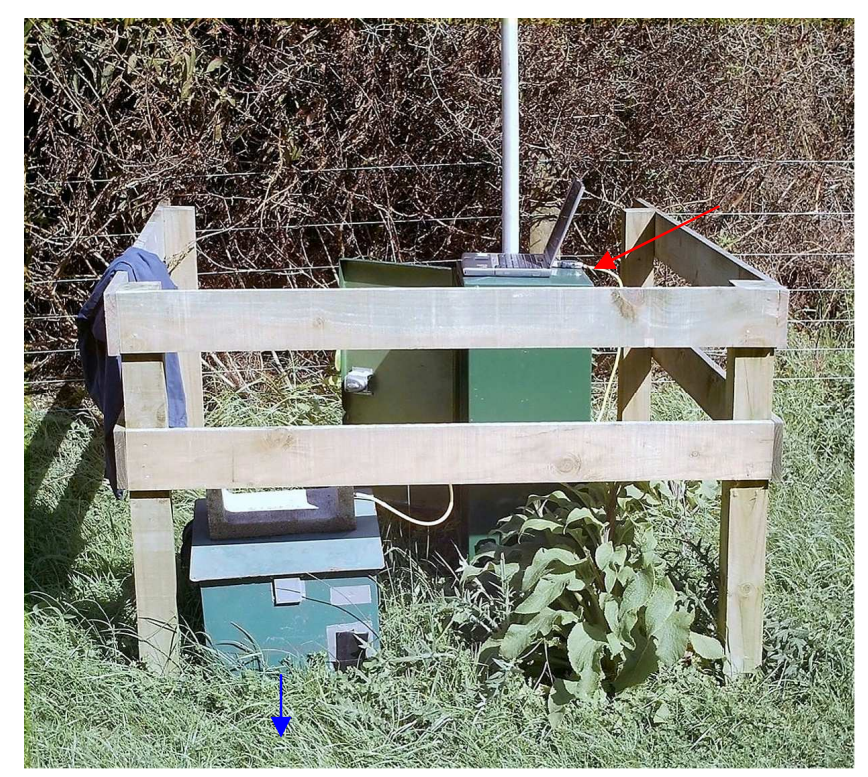

Figure 4.12 Site 1, showing the telemetered groundwater site that is monitored by GW (see red arrow). The baroTROLL used for this study was also located in this housing. This site also contains a set of TDR probes. The probes are buried at set depths towards the foreground of the photograph (see blue arrow).

Site 1 (Figure 4.11) is part of the Greater Wellington Regional Council's groundwater monitoring programme. The site consists of a pressure transducer and an Iris 220 logger with gprs (Vodafone) telemetry communication ability. The site is 
programmed to record at 15 minutes intervals. Data are sent back to the base station in Wellington every two hours, and updated on the Council web site. Water level in the well is measured using an ISD pressure transducer, with $10 \mathrm{~m}$ of cable and a $5 \mathrm{~m}$ range, 0-5V (Purdon, Pers Comm. 2007).

An electric plumb bob (EPB) and tape is fitted to manually calibrate the transducer and logger. Council staff compare the 15 minute measurements with the EPB readings to ensure they are within specified limits. Power is provided via a small solar panel which feeds into a solar regulator then through the battery to the logger. Battery charge is logged every hour so Council staff can monitor the site from Wellington. This prevents loss of data (Purdon, Pers Comm. 2007). Every station is checked each morning as part of flood warning procedures to ensure accurate and reliable data.

A water level dipper is used to manually measure the water level in a piezometer. The dipper is a flat tape that is graduated in metres, and wound onto a drum. Wires run down the sides of the tape, and are attached to a probe that consists of two electrodes. When the probe meets the water surface it completes a circuit. This activates a buzzer and a light (Brassington, 2007).

To take a measurement, the probe is lowered down the well until it touches the water surface and the buzzer sounds. The tape is then pulled slowly back out of the water until the buzzer stops. This is repeated several times for consistency and to get an accurate reading. The water level measurement is then taken to the nearest centimetre. The level on the tape is recorded against a fixed datum, in this case the top of the bore casing (Brassington, 2007). The time, as well as the water level, is recorded.

On the first site visit, the water level dipper was used to measure the total depth of each borehole. For both Sites 2 (Figure 4.3) and 6 (Figure 4.13) this was found to be $6.4 \mathrm{~m}$ from the top of the bore casing. The total depth of the wells was re-checked on the next two site visits. The measurements recorded using the water level dipper, were used to ensure the accuracy of the continuous water level record. The water levels in the piezometers were measured on each site visit, approximately every $4-6$ weeks. 


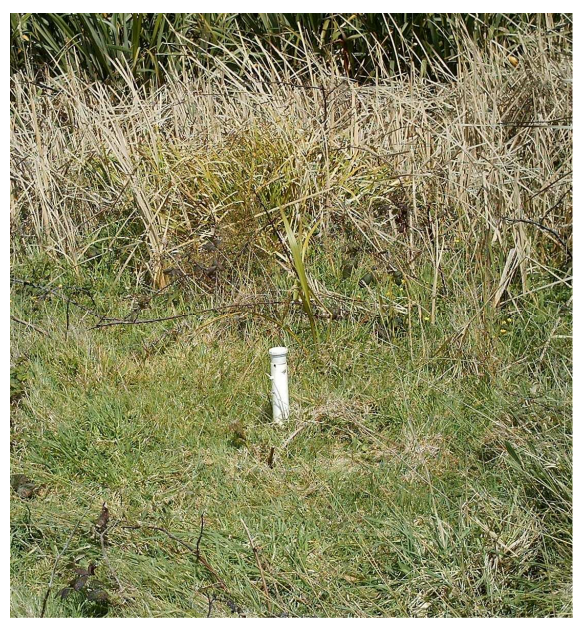

Figure 4.13 The location of the groundwater monitoring bore at Site 6 . The bore is located on a small dune surrounded by wetland. The flax in the background of the photograph indicates the close proximity of the bore to the wetland.

To obtain high resolution temporal coverage of groundwater level fluctuations, continuous recordings were also made at Sites 2 and 6. Combined pressure transducers and dataloggers, miniTROLLs from In-Situ Inc, were used. The miniTROLLs used had the same specification as those used at Sites 3, 5 and 7 for the measurement of surface water level. The miniTROLLs were installed in the boreholes to a depth of four metres (taken from the top of the bore casing). This depth was chosen to ensure that the pressure transducer would always be below the water surface. The loggers were programmed to record data every five minutes. Data were collected from the dataloggers at approximately $4-6$ week intervals.

\subsubsection{Groundwater flow direction}

Using cartographic methods a piezometric surface contour map from point observations of water levels in a network of boreholes can be constructed. A minimum of three observation points are needed to determine flow direction (Brassington, 2007). Provided that the water level data are representative, both spatial and temporally, it is possible to draw groundwater flow line at right angles to the contour lines (Brassington, 2007, Ward, 1967). Using the data gathered from Sites 1, 2 and 6, a contour map with groundwater flow lines was constructed. Due to the topography of the area and the uniformity of the aquifer media the use of only a few bores is representative. 


\section{6: Soil moisture}

Soil hydraulic properties allow an understanding of the dynamic processes of water and solute movement within the soil (Wang et al. 1998). Time Domain Reflectometry (TDR) is a reliable method for measuring soil volumetric water content (Ren et al., 1999). TDR probes record the electric constant of soil by measuring the transmission time of an electromagnetic pulse between a pair of parallel steel rods of known length embedded in the soil (Rawls et al.,1993). This method allows continuous, real time, in situ measurements (Ren et al., 1999). The volumetric water content of the soil is the measure of the volume of water as a percentage of the total volume of soil (Drnevich et al., 2005 and Yu and Drnevich 2004).

TDR probes used for long term monitoring of soil moisture content and movement are installed horizontally into the wall of a pit. Horizontal probe installation allows for the measurement of soil moisture at one depth within the soil profile (Delin and Herkelrath, 2005). TDR probes were installed at Sites 1, 2 and 4. At each site a pit was dug roughly $0.5 \mathrm{~m}$ wide $0.7 \mathrm{~m}$ long and $1.2 \mathrm{~m}$ deep. The water table was reached in each case, shown by water seeping into the bottom of each pit (Figure $4.14 \mathrm{a}, \mathrm{b}$ and c).

Six probes were installed horizontally at measured depths at each site. The shallowest, were at $10 \mathrm{~cm}$, and $20 \mathrm{~cm}$ depths and then at $20 \mathrm{~cm}$ increments down to the sixth probe which was installed at $100 \mathrm{~cm}$. The sandy substrate of the sites meant that no drilling was required to install the probes. The location of all the TDR probes can be seen in Figure 4.1, and the location of each set of TDR within a specific site can be seen in Figures 4.3, 4.4, and 4.11. Campbell Scientific CR10X data loggers were programme to record the data from each probe at 15 minute intervals. 


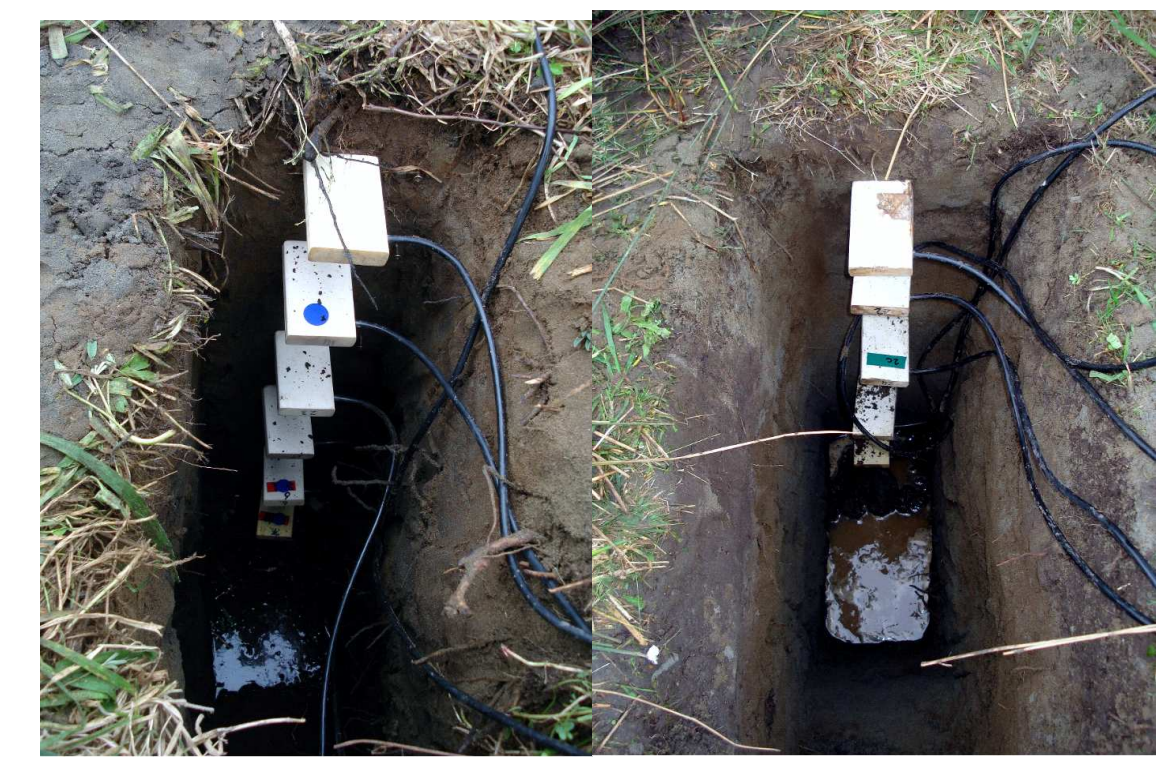

(a)

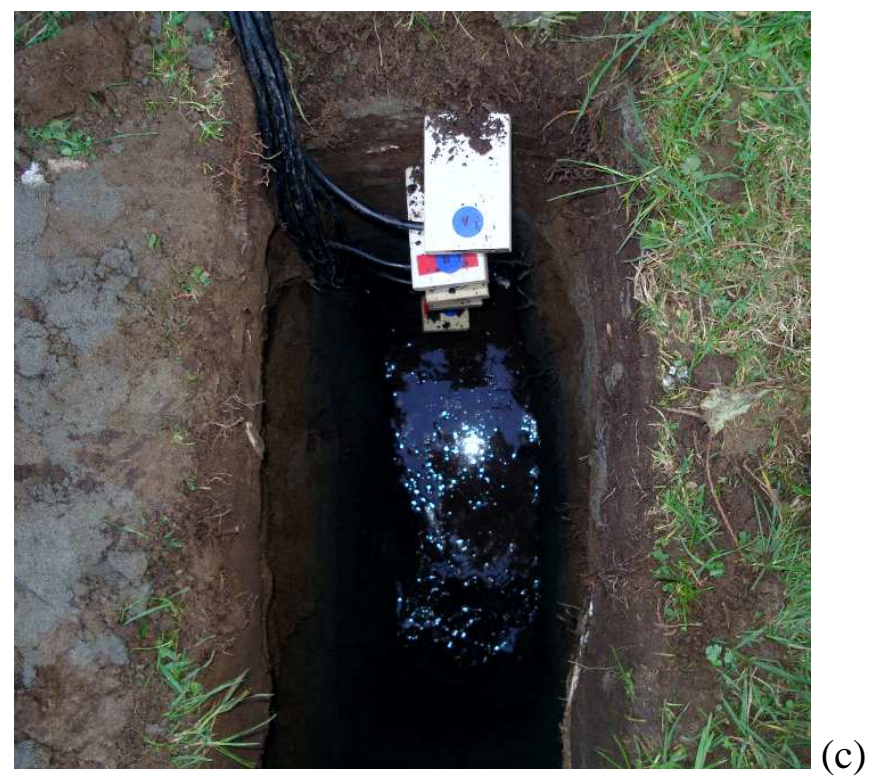

(b)

Figure 4.14 The TDR pits at sites 1 (a) 2 (b) and 4 (c). Note the presence of water at the bottom of each pit.

The use of TDR probes is an indirect, non-destructive (aside from the initial excavation for installation) method to measure soil moisture content (Teixeira et al. 2003). By installing probes at different depths within the soil profile, the percolation rate can be estimated. It is also possible to evaluate the wetting front movement through the unsaturated zone of the soil (Delin and Herkelrath, 2005).

\section{7: Water Balance Equation}

A water balance provides a general framework from which interactions between the wetland and surrounding area can be evaluated. The information can also be used to 
quantify nutrient or sediment fluxes (Drexler et al. 1999). To quantify the hydrological regime of Te Harakiki, and determine its most important controls, a semi-quantitative water balance was calculated. This used the equations (given in chapter 2) set out below.

Equation 2.1: $\quad$ Input - Output $=$ Change in storage

Equation 2.2: $\quad\left(P+Q_{\text {in }}+\mathrm{G}_{\text {in }}\right)-\left(\mathrm{E}+\mathrm{Q}_{\text {out }}+\mathrm{G}_{\text {out }}\right)=\Delta \mathrm{S}$

Where: $\Delta \mathrm{S} \quad=$ change in stored water within the wetland

$\mathrm{P} \quad=$ Precipitation

$\mathrm{Q}_{\text {in }} \quad=$ surface water inflows

$\mathrm{Q}_{\text {out }}=$ surface water outflows

$\mathrm{G}_{\text {in }} \quad=$ groundwater inflows

$\mathrm{G}_{\text {out }}=$ groundwater outflows

$\mathrm{E} \quad=$ Evapotranspiration

Source: Campbell and Jackson, (2004) pp 20.4

A water balance can be calculated using mean values over specific time periods. A mean annual water balance is the most simple to calculate, as it is usually possible to disregard changes in water storage (Sokolov and Chapman, 1974). Time constraints meant that the water balance for Te Harakiki was calculated using mean monthly data. These data were then totalled to give the mean water balance for the study period.

The components included in a water balance equation can be considered as random variables, both spatially and temporally. Annual precipitation and evapotranspiration levels can vary from year to year, as can surface and ground water levels.

Mean monthly precipitation rates were calculated from the data gathered at Sites 2, 4, and 7 using applications in HILLTOP (Version 4.42). Because of equipment failures, the data from Sites 2 and 4 proved to be unreliable. Therefore, only rainfall data from Site 7 were included in the water balance calculation. It is believed that the limited spatial variation in rainfall over the three sites, but this could not be confirmed because of gaps in the data from Sites 2 and 4.

Monthly evapotranspiration was calculated using meteorological and climatic data from Paraparaumu Airport. The FAO Penman-Monteith equation for reference crop evapotranspiration was used. This ignored the effect of species diversity but 
simplified the approach. The values gathered from this method were included in the water balance equation.

The velocity - area method for calculating stream discharge was used to construct rating curves for the Ngarara Stream. Rating curves were constructed for Sites 3, 5 and 7. Discharge measurements were made using a current meter. The 0.6 method was used to gauge the mean velocity at each vertical as the stream depth was rarely above $0.75 \mathrm{~m}$ (Mosley et al. 1992). The construction of a rating curve allows the conversion of the stage record for each site into a discharge record (Wisler and Brater, 1959). The discharge data from Sites 3 and 7 were then incorporated into the water balance equation as surface water inflow.

Surface water outflow or the loss of water from the wetland to the stream channel was analytically calculated using the following equation:

$$
\mathrm{Q}=2\left(\mathrm{k}_{\mathrm{x}} / 2 \mathrm{~L}\left(\mathrm{H}^{2}-\mathrm{h}_{\mathrm{e}}\right)\right)
$$

Where $\mathrm{Q}=$ flow to stream channel per unit length

$\mathrm{k}_{\mathrm{x}} \quad=$ horizontal hydraulic conductivity (assumed $5 \mathrm{~m} /$ day)

$\mathrm{L}=$ distance to unaffected wetland water table (assumed $5 \mathrm{~m}$ )

$\mathrm{H}$ = saturate thickness from the base of the channel to the water table at $\mathrm{L}$ (assumed $0.75 \mathrm{~m}$ i.e. $0.25 \mathrm{~m}$ head difference

$\mathrm{h}=$ average depth of water in the channel

A stream channel length of 1600m was used (Phreatos, 2002)

Groundwater discharge is generally considered the most difficult component of the water balance to quantify as it cannot be measured directly (Favero et al. 2007). Wetland groundwater inflows and outflows are usually calculated using Darcy's Law. The following equation (given in Chapter Two) was used to calculate groundwater inflow and outflow:

$$
\mathrm{Q}=K \cdot A . i
$$

Where: $\mathrm{Q} \quad=$ the volume of water flowing from a porous medium

$A=$ the cross sectional area

$i \quad=$ hydraulic gradient

$K \quad=$ hydraulic conductivity of the porous medium

Source: Ward, (1967) p 272. 
The values for hydraulic conductivity at each site were taken from those given for Taupo, Foxton and Waiterere dune sands in Phreatos (2002). The cross sectional area of the wetland was also taken from Phreatos (2002).

The hydraulic gradient was calculated using the following equation:

$$
i=\left(\mathrm{h}_{2}-\mathrm{h}_{1}\right) / \mathrm{d}
$$

Where: $i=$ hydraulic gradient $[\mathrm{L} / \mathrm{L}]$

$\mathrm{h}_{2}=$ down gradient head [L]

$\mathrm{h}_{1} \quad=$ up gradient head [L]

$\mathrm{d}=$ distance between wells [L]

The hydraulic head of the piezometers is given by:

$$
\mathrm{h}=\mathrm{z}+\mathrm{h}_{\mathrm{p}}
$$

Where: $\mathrm{h}=$ the hydraulic head

$\mathrm{z}=$ elevation at surface of the datum point

$\mathrm{h}_{\mathrm{p}} \quad=$ the height of the water in the column that provides a pressure head Source: Fetter, (2001).

\section{8: General errors}

Multiple sites with similar equipment were established around the wetland, to quantify the hydrological regime. Having multiple sites measuring the same variables also provided 'back-up' should any of the recorders fail. This proved to be a prudent measure.

The Campbell Scientific CR10X data logger installed at Site 2 was replaced on two occasions because of apparent failure, and an inability to communicate with the logger to download data. This resulted in two significant gaps in the data from this site. After the second occasion, the logger was sent for performance testing and the loss of data was found to be caused by a RTC Crystal failure.

The cable and power connection to the logger also proved to be problematic. This connection became dislodged and led to a loss of contact. The cable from Site 2 was 
replaced when the first logger was changed. This was also the likely cause of the logger at Site 4 (also recording soil moisture and rainfall) failing to record data for a four week period.

The only complete rainfall record was from Site 7. This was despite the fact that this site was vandalised. Although the gauge housing was destroyed it corresponded with a period of no rainfall when checked against adjacent gauges. The fact that the sites were visited only monthly meant that any problems with equipment could lead to the loss of up to 4 weeks data. A telemetered monitoring system would have reduced data losses but this was not feasible for this project.

\section{9: Summary and research structure}

This chapter has outlined the various techniques applied in this study. The results now be discussed: in relation to each other, and in the context of surface and groundwater flow, their influence on the water balance of the area and the implications of this on the future management of the Te Harakiki wetland system. 


\section{Chapter 5: Results}

\section{1: Aerial photograph analysis}

\subsubsection{Wetland (lagoon) extent}

In 1966 the study area contained two open water lagoons (Figure 5.1(a)), but one (Rawakahia Lagoon) was drained during the construction of the Waikanae oxidation ponds in the 1970's (Phreatos, 2002). Between 1966 and 1996 the other, Totara Lagoon, deceased in size by approximately $11.3 \mathrm{ha}(86 \%)$, or at rate of 0.37 ha per year. By 1996 it was just over 1.8ha (Figures 5.1 (a) - 5.1 (d) and Table 5.1). The largest percentage loss in area was in the decade between 1986 and 1996 when the lagoon decreased in size by 62\%. The twelve years between 1966 and 1978 saw the greatest rate of loss of wetland (0.43ha per year).

Table 5.1. Change in lagoon extent (Area and \%) 1966 - 2002

\begin{tabular}{|c|c|c|c|}
\hline Year & Area (ha) & $\begin{array}{c}\text { Area loss (ha) per } \\
\text { year }\end{array}$ & $\begin{array}{c}\text { Percent (\%) } \\
\text { change }\end{array}$ \\
\hline 1966 & 13.19 & --- & -- \\
\hline 1978 & 8.07 & -0.43 & -38.78 \\
\hline 1986 & 4.88 & -0.40 & -39.58 \\
\hline 1996 & 1.86 & -0.30 & -61.86 \\
\hline 2002 & 2.60 & +0.10 & +28.35 \\
\hline Total 1966- 1996 & -11.33 & -0.37 & -85.90 \\
\hline
\end{tabular}

The data from this table is shown graphically in figure 5.1 (a) - (e)

During the six years between 1996 and 2002 Totara lagoon increased in size by $0.73 \mathrm{ha}(28.3 \%$ ), or at a rate of 0.10 ha per year. The lagoon was 2.6ha in 2002 (Figure 5.1 (e)). This is a relatively small rate of increase when compared to the rate at which the lagoon shrank during the previous 30 years.

Even with the recent increase in size, the lagoon is now $80 \%$ smaller than it was only half a century ago. The construction of the oxidation ponds during the 1970's resulted in the loss of the Rawakahia Lagoon, and 55.9ha of natural open water wetland 
habitat. This loss was partially offset by the oxidation ponds themselves which have a larger area of open water than the original lagoon (71.84ha). The oxidation ponds were decommissioned in 2002 but still contain water, providing open-water habitat.

\subsection{2 : Urban area extent}

Waikanae Beach settlement, that borders Te Harakiki to the west, increased by 290ha (60\%) or 9.7 ha per year between 1966 and 1996. The largest increase occurred in the 12 year period between 1966 and 1978. During this period the settlement grew by approximately 170 ha $(46 \%)$ or 14.2 ha per year (Table 5.2$)$. The survey method used only took into account the physical area taken up by housing, not the density of the housing in the area.

Table 5.2. Changes in urban extent (Area and \%)

\begin{tabular}{|c|c|c|c|}
\hline Year & Area (ha) & $\begin{array}{c}\text { Area change (ha) } \\
\text { Per year }\end{array}$ & $\begin{array}{c}\text { Percent (\%) } \\
\text { change }\end{array}$ \\
\hline 1966 & 196.87 & --- & --- \\
\hline 1978 & 367.64 & +14.23 & +46.45 \\
\hline 1986 & 414.76 & +5.89 & +11.36 \\
\hline 1996 & 488.15 & +7.4 & +15.03 \\
\hline 2002 & 489.02 & +0.12 & +0.18 \\
\hline $\begin{array}{c}\text { Total 1966 - } \\
\text { 1996 }\end{array}$ & +291.29 & +9.70 & +59.67 \\
\hline TOTAL & +292.16 & +7.90 & +59.74 \\
\hline
\end{tabular}

Data from this table is shown graphically in Figures 5.2 (a) - (e)

These data were then compared with NZ census data for Waikanae Beach over the same time period (Table 5.3). There was a large increase in recorded population over the 10 years between the 1966 and 1976 censuses. The population grew from 97 to 225 people, an increase of almost 57\% (or 12.8 people every year). This is consistent with the large increase in size of the urban area seen in Table 5.2 and Figures 5.2 (a) (b).

The largest population increase for Waikanae Beach occurred in the decade between 1986 and 1996. The population increased by nearly $93 \%$ (or 186 people every year 
during the period). It increased from just 150 people to over 2000. The large population increase between 1986 and 1996 is not shown as an increase in urban area in Figure 5.2. It may, however, be reflected in an increase in housing density, or be the result of the change in census area definition. There was a change in census area definition between the 1976 and 1986 census, possibly explaining the decrease in population seen during this period.

Table 5.3 Population data for Waikanae Beach 1966 - 2006

\begin{tabular}{|c|c|c|c|}
\hline Year & Population & $\begin{array}{c}\text { Population } \\
\text { change people } \\
\text { per year }\end{array}$ & $\begin{array}{c}\text { Population } \\
\text { increase (\%) } \\
\text { change }\end{array}$ \\
\hline 1966 & 97 & ---- & ---- \\
\hline 1976 & 225 & +12.8 & +56.88 \\
\hline 1986 & 147 & -7.8 & -34.66 \\
\hline 1996 & 2007 & +186 & +92.67 \\
\hline 2001 & 2451 & +44.4 & +16.57 \\
\hline Total 1966 - 1996 & & +63.7 & +95.17 \\
\hline TOTAL*** & 2892 & +69.9 & +96.65 \\
\hline
\end{tabular}

Source: Statistics New Zealand (2006 and 2007) *** total is from 2006 census data.

Population statistics for the Waikanae area - Pre 1971 "Waikanae location," pre 1991 "Waikanae vicinity" Post 1991 data are from Waikanae Beach settlement. Note: local government reorganisation in 1989 changed most boundaries; data not geographically comparable. 


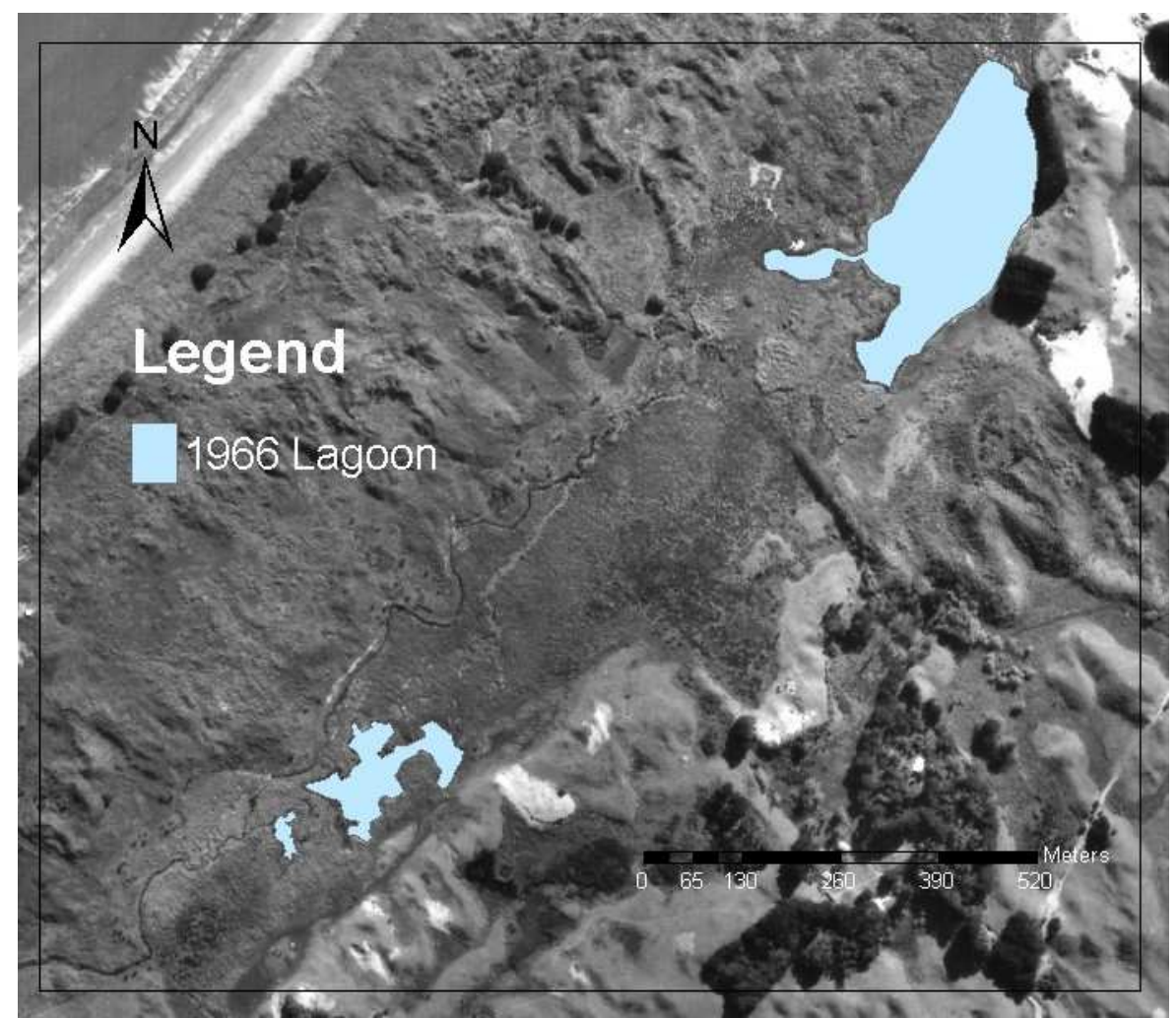

Figure 5.1 (a) Lagoon extent in 1966. Note that both Totara and Rawakahia Lagoons can be seen.

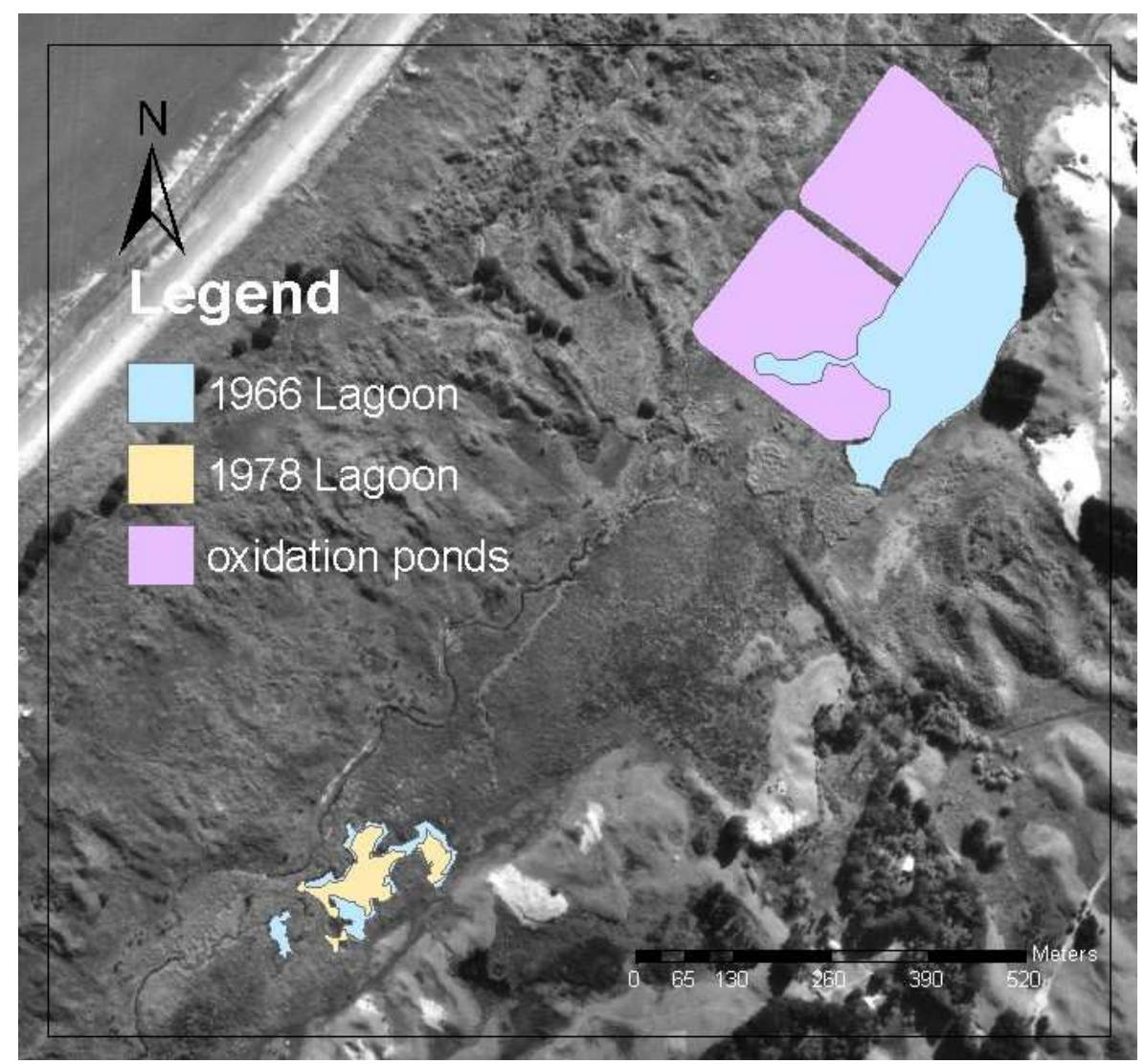

Figure 5.1 (b) Change in lagoon extent 1966 - 1978. Note the drainage of Rawakahia Lagoon and the construction of the oxidation ponds. 


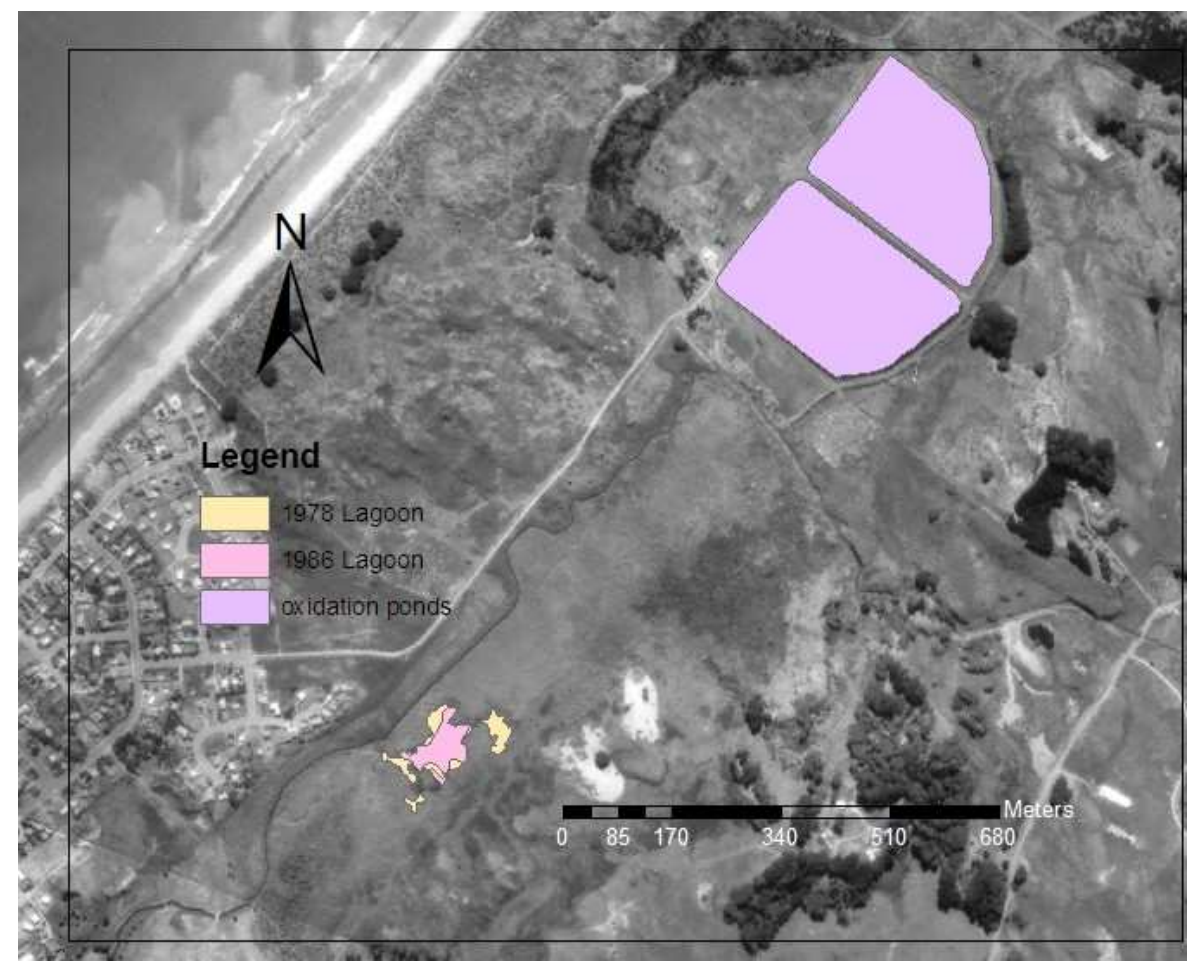

Figure 5.1 (c) Change in lagoon extent 1978 - 1986

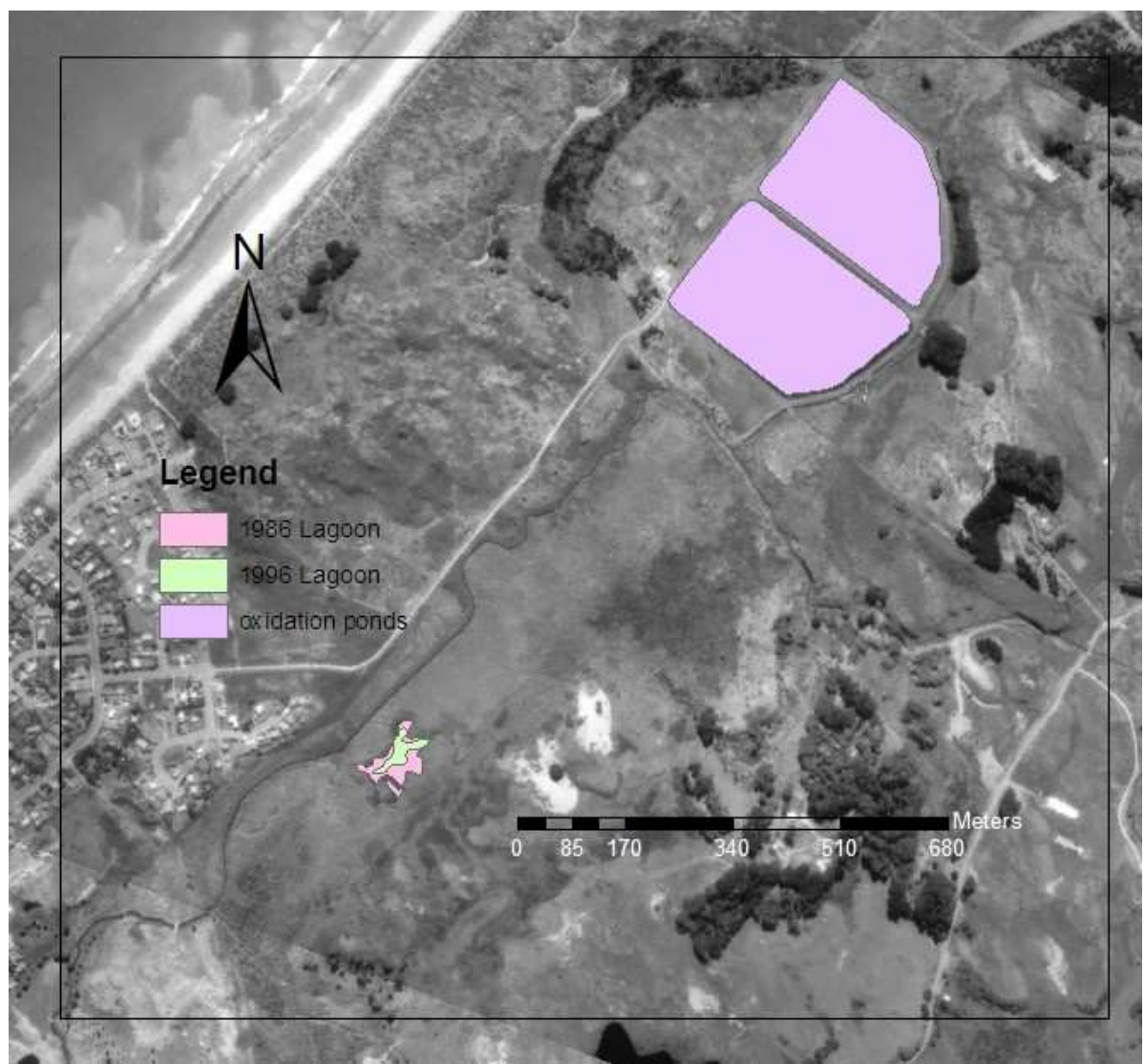

Figure 5.1 (d) Change in lagoon extent 1986 -1996 


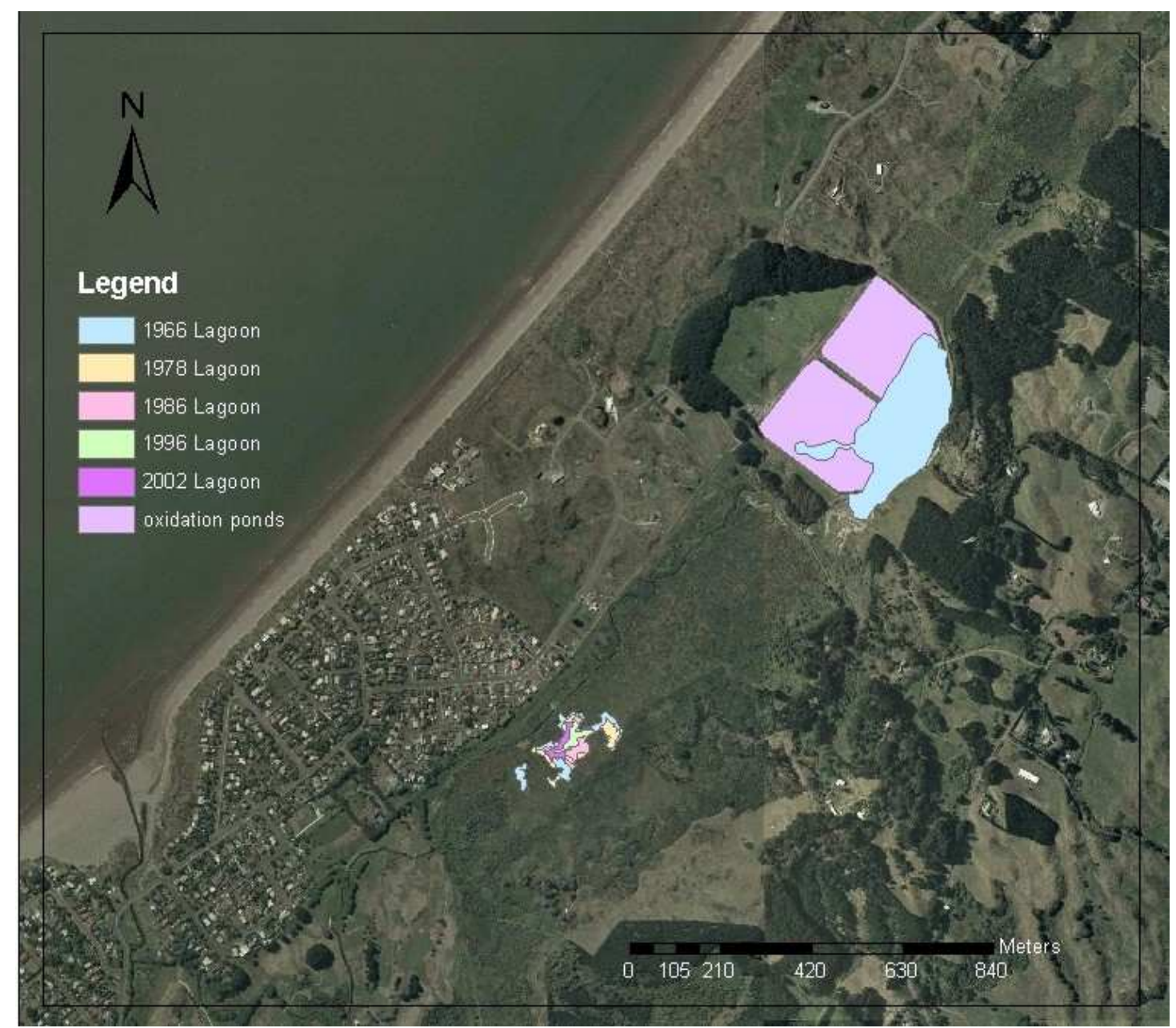

Figure 5.1 (e) Change in lagoon extent 1996-2002. Note this is the only period when the lagoon increases in size. 


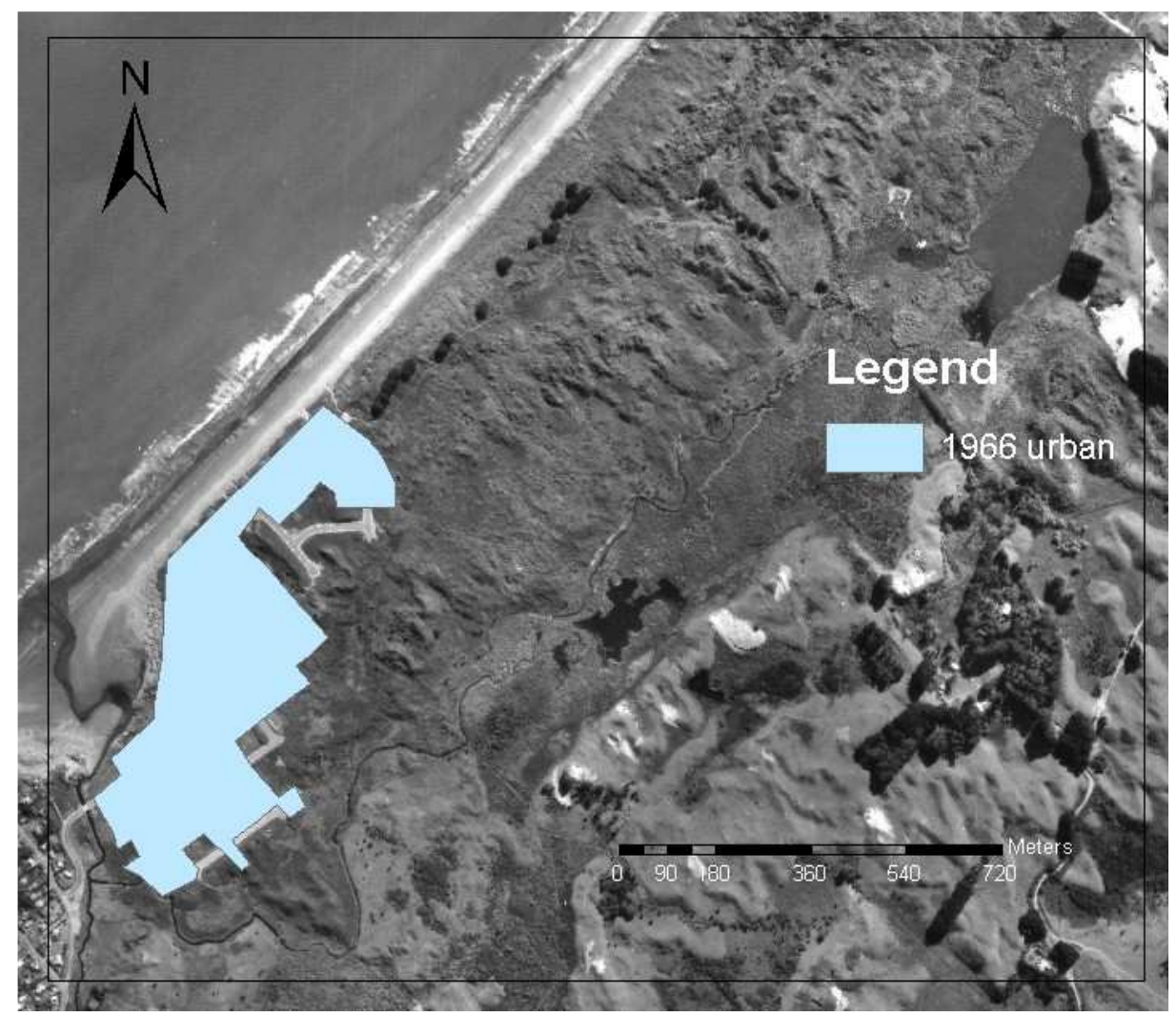

Figure 5.2 (a) Urban area extent 1966

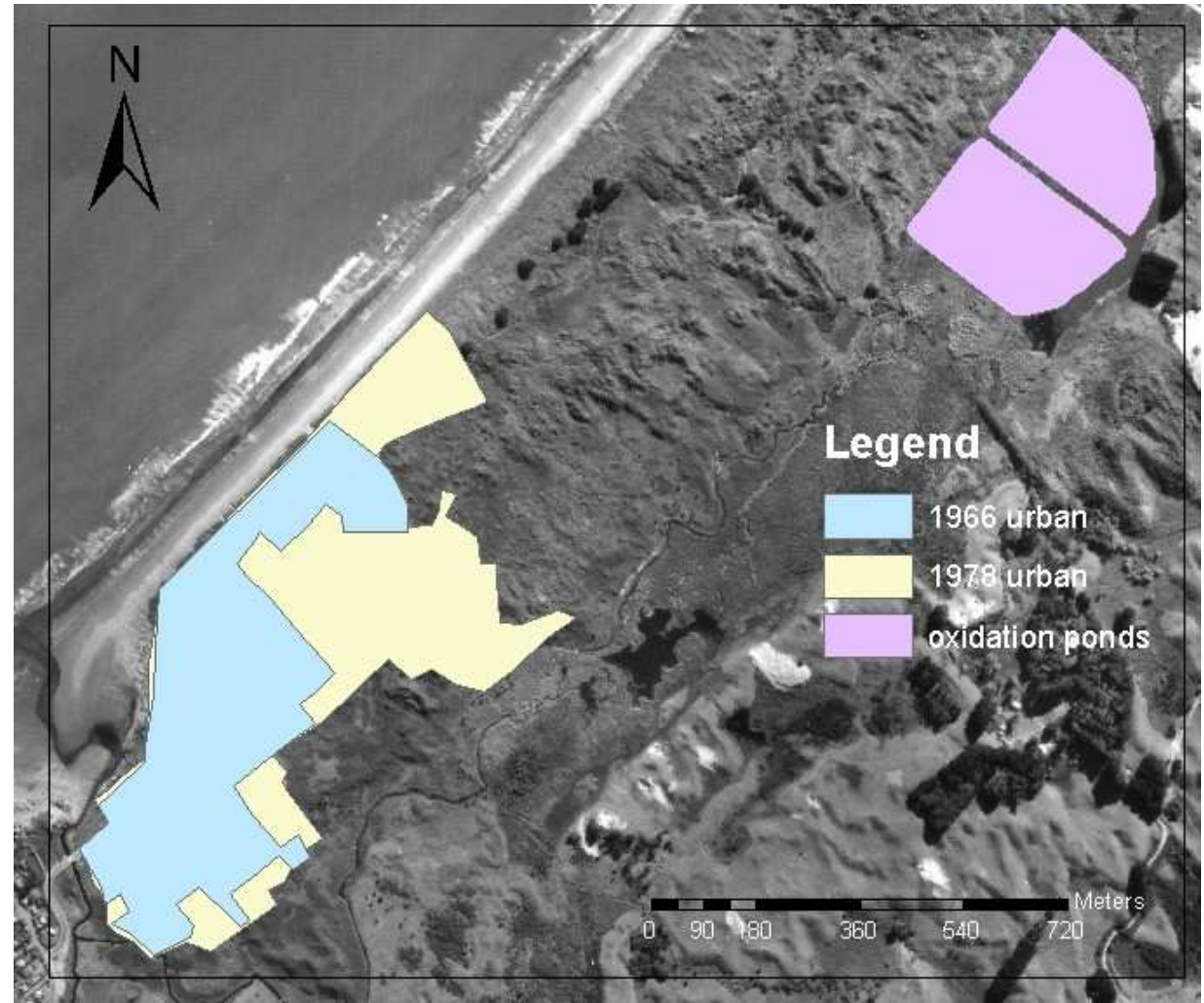

Figure 5.2 (b) Changes in urban area extent 1966 - 1978. 


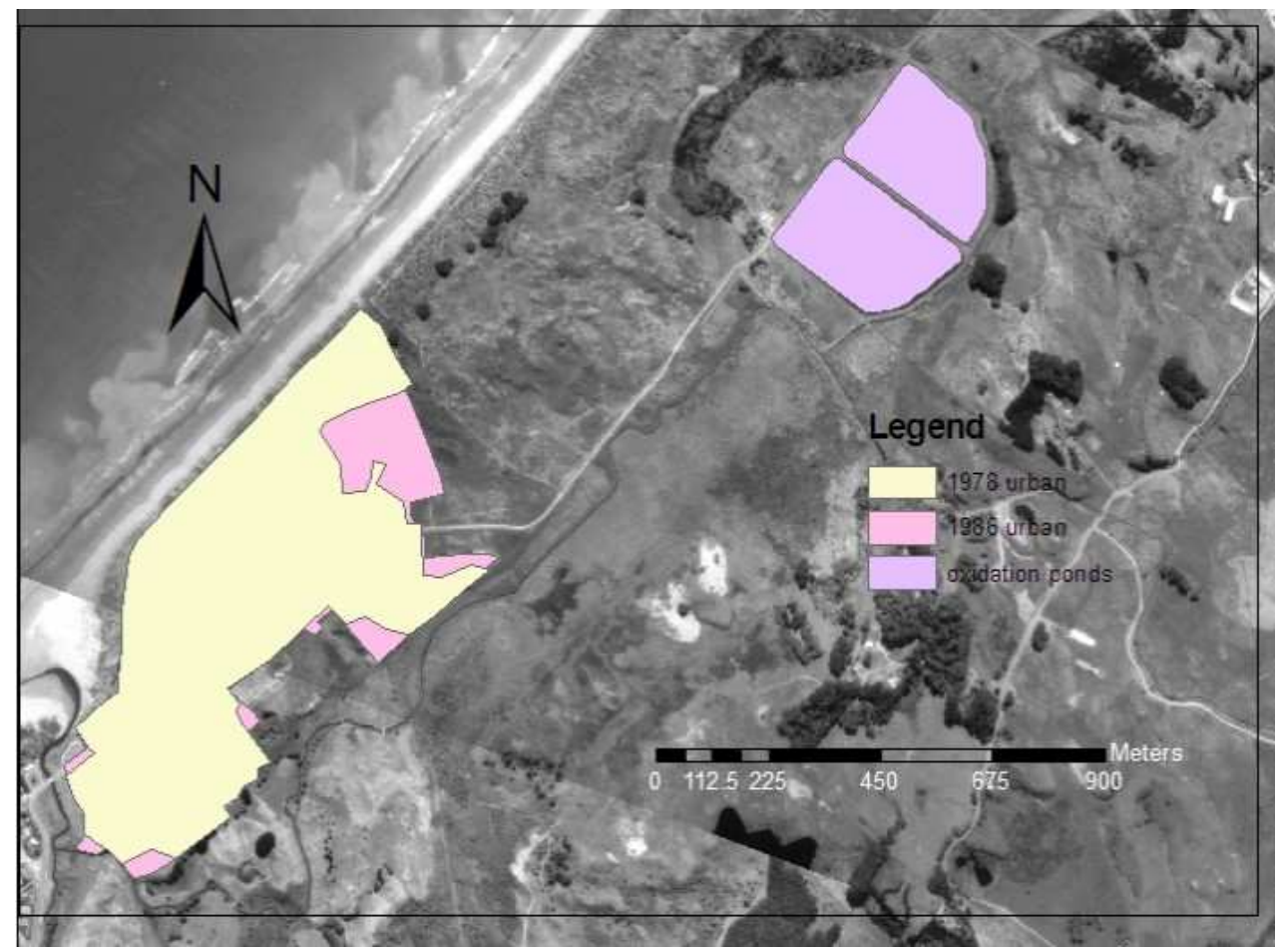

Figure 5.2 (c) Changes in urban area extent 1978 - 1986.

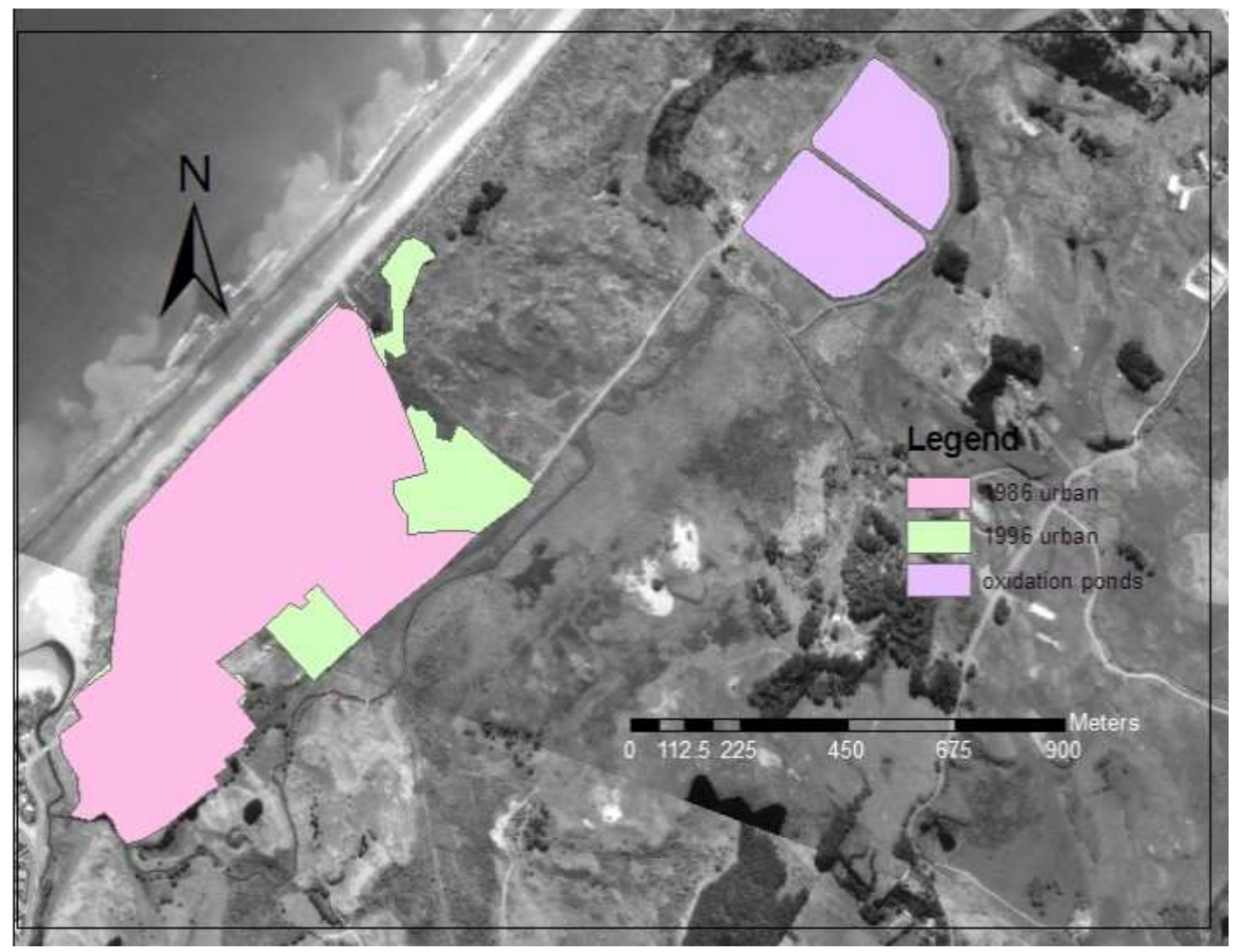

Figure 5.2 (d) Changes in urban area extent 1986 - 1996 


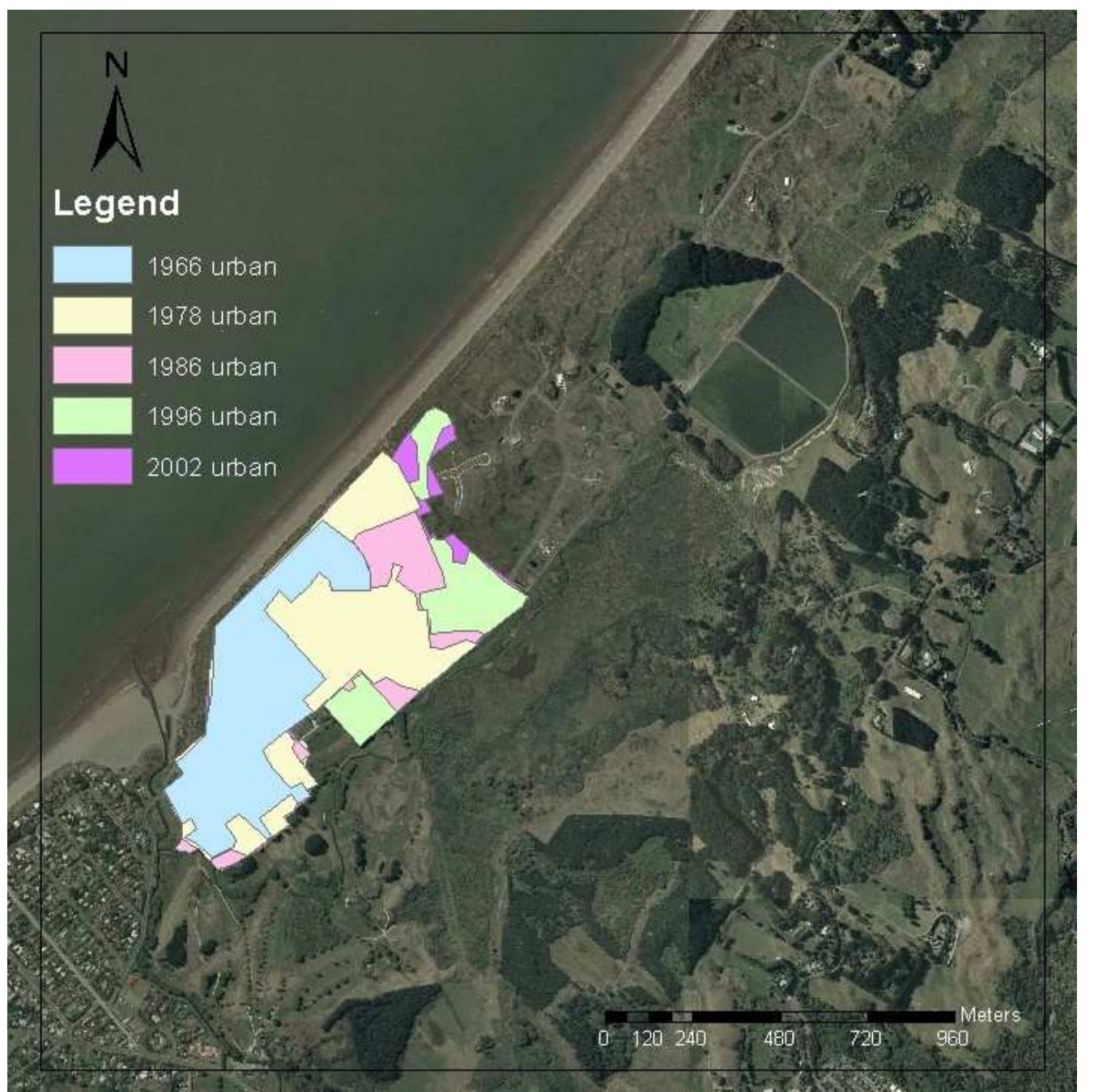

Figure 5.2 (e) Changes in urban area extent 1996 - 2002. Note that the oxidation ponds were decommissioned in 2002. 


\section{2: Hydrometric Time Series Analysis}

\subsubsection{Introduction}

To better understand the interactions and dynamic nature of both surface and shallow groundwater responses within the Te Harakiki Wetland system a time series analysis was undertaken. The response of surface and groundwater levels to precipitation was assessed. This was then compared with an analysis of the progression of the wetting front through the soil profile.

\subsubsection{Groundwater and surface water}

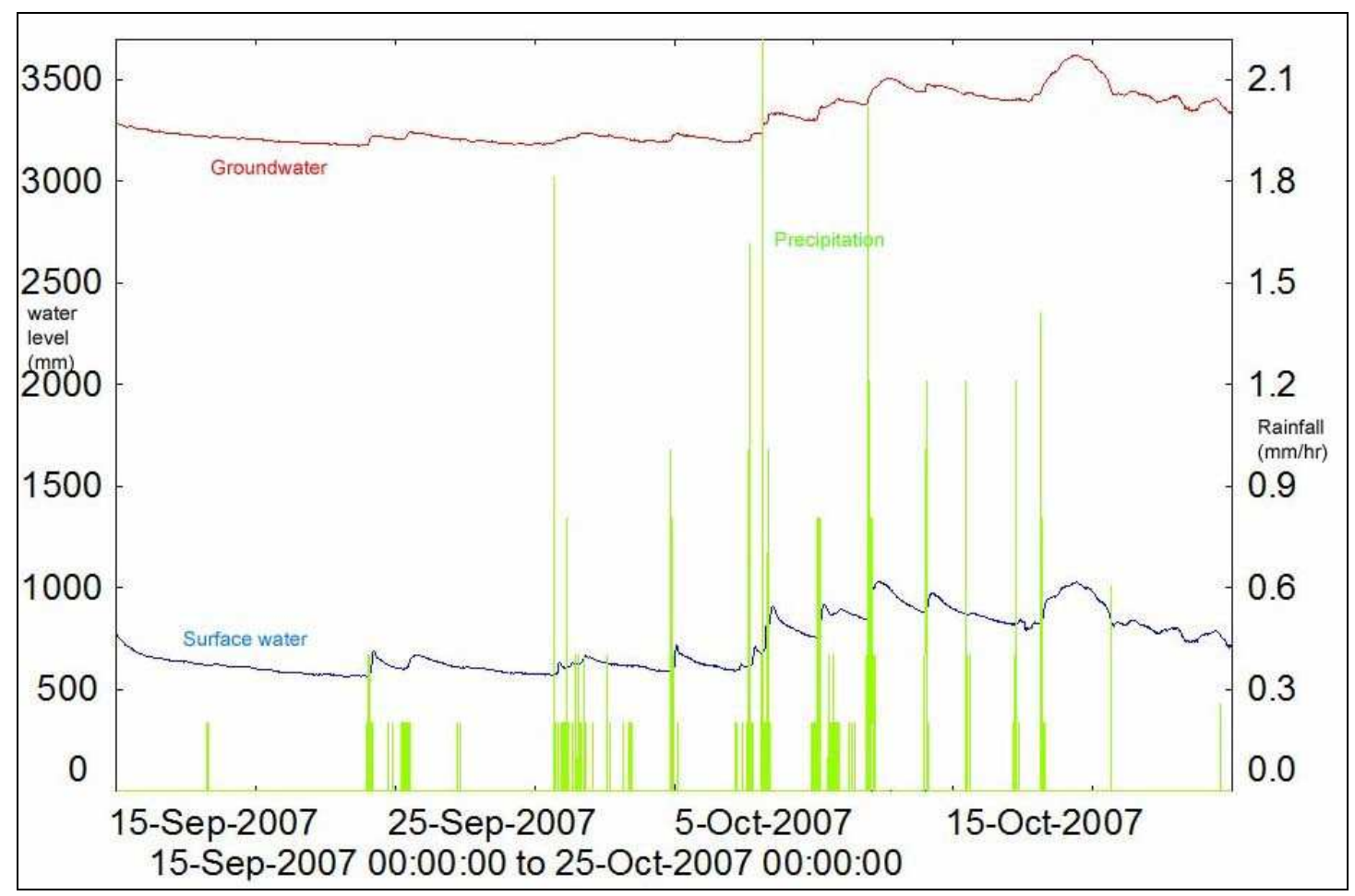

Figure 5.3 The response of surface and groundwater levels at Te Harakiki to a rainfall event.

Between September 30th and October 21st an average of $3.5 \mathrm{~mm} /$ day of rainfall was recorded at Te Harakiki by the rain gauge at Site 7. Both the shallow groundwater and surface water systems responded significantly to this precipitation event. Ngarara Stream responds rapidly to any rainfall event with intensities over about $0.2 \mathrm{~mm} / \mathrm{hr}$. Flood peaks usually occur less than 30 minutes after the onset of rainfall. A similar pattern of response can be seen in the shallow groundwater level, but this response is more subdued and moderated. This is consistent with Jones and Gyopari (2005) who found that the shallow groundwater aquifer on the Kapiti Coast responds rapidly to 
rainfall recharge. The shallow groundwater system quickly responds to rainfall events with intensities over $0.5 \mathrm{~mm} / \mathrm{hr}$. A high intensity rainfall event results in larger peaks in both groundwater and surface water level. Both the surface and groundwater systems respond more rapidly to higher intensity events (Figure 5.3). There is a short residence time for water within the surface water system. The storm water drains from the system within 30 hours of a rainfall event. The residence time within the groundwater system is much longer. Rainfall events that occur on successive days add to the groundwater storage, and the rainfall derived peaks are on top of a higher base level (Figure 5.3).

\subsubsection{Tidal effects}

Figures 5.4 and 5.5 show the influence of tide on water level at Site 7. The flood peaks in Figure 5.4 (numbered 1-5) occur almost simultaneously at both Sites 3 and 7, in response to precipitation events. There is a small lag (on average 5 minutes) between peaks at the upstream and downstream sites. Given the distance between Sites 5 and 7 the average flow velocity during a rainfall event would have to be $2.8 \mathrm{~m} / \mathrm{sec}$. This is far greater than the measured stream velocity of $0.04 \mathrm{~m} / \mathrm{sec}$.

There are many more peaks and troughs in water level at Site 7 than recorded at either Site 3 or 5. This is shown clearly in Figure 5.5 where no large precipitation events occurred to cause the apparent peaks in water level. Tidal influences do not extend to Site 5 (a further $800 \mathrm{~m}$ upstream) as water level remains relatively constant. A precipitation event on September 4 caused a small peak in water level at both sites.

The cyclic nature of the peaks and troughs at Site 7 suggest that they are caused by incoming and outgoing tides. Site 7 is located approximately $1855 \mathrm{~m}$ upstream of the stream mouth.

The predicted times and heights of tides for the period covered by Figure 5.5 are given in Table 5.4. These were calculated for the Waikanae River mouth from data at Port Taranaki using the method provided by LINZ. There is an average lag time of 52 minutes from the estimated high tide being recorded at the Waikanae River to its 
effects being seen on water level at Site 7. The tidal influence on water level travels upstream at an estimated average rate of $0.59 \mathrm{~m} / \mathrm{sec}$.

Although there is a discernable effect of the tides to be seen at Site 7, their precise influence the water level is complicated. A $1.75 \mathrm{~m}$ high tide on August 30 caused the water level at Site 7 to rise by $0.164 \mathrm{~m}$. The same size high tide on September 2 however, caused the water level to rise by $0.302 \mathrm{~m}$. A $1.70 \mathrm{~m}$ high tide on August 27 resulted in an increase in water level of $0.024 \mathrm{~m}$. The same height tide on August 28 caused an increase of $0.033 \mathrm{~m}$.

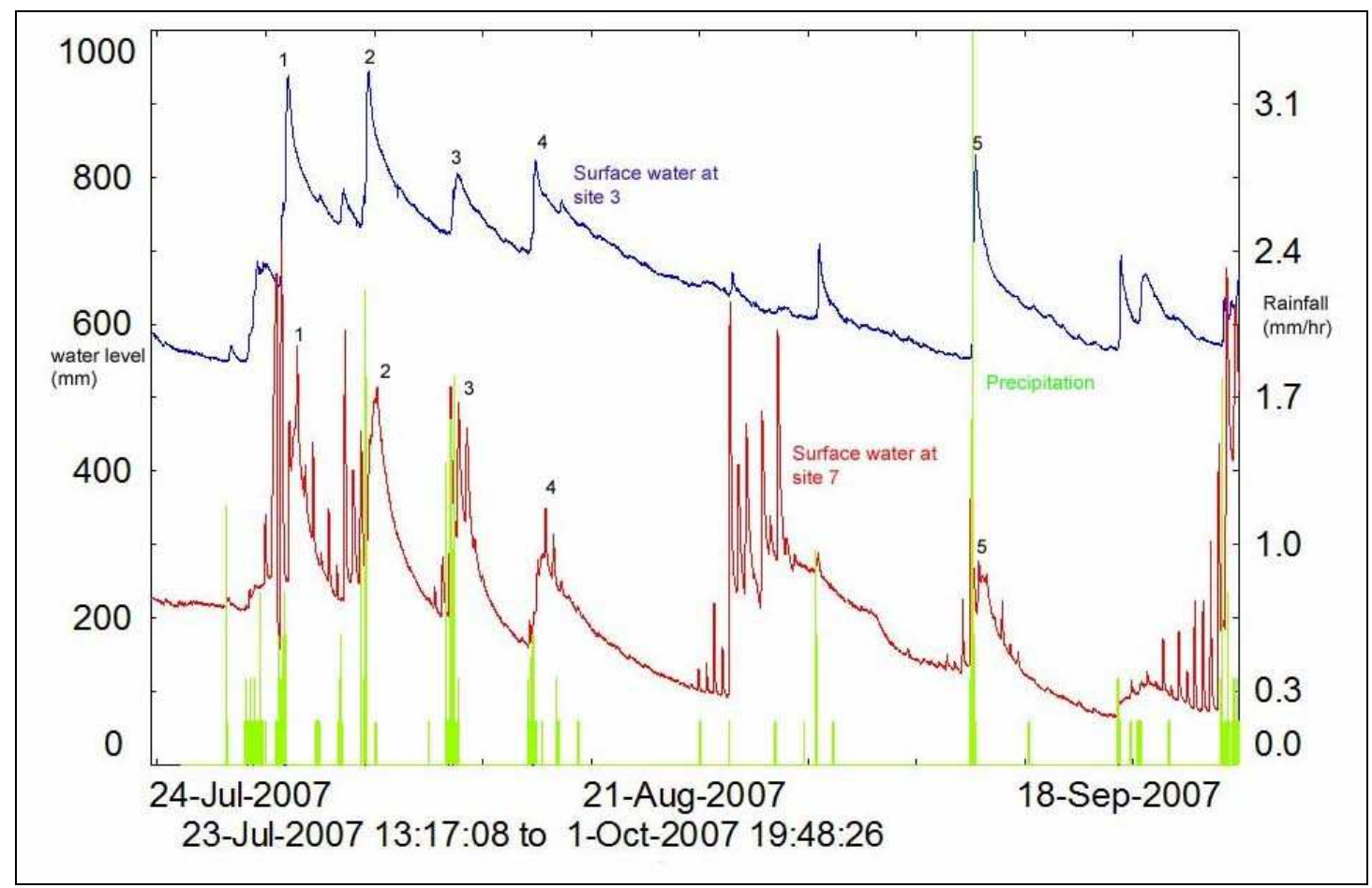

Figure 5.4 Ngarara Stream at sites 3 and 7, illustrating the tidal influence at site 7. Corresponding peaks in surface water level as a result of precipitation are numbered 1-5. 


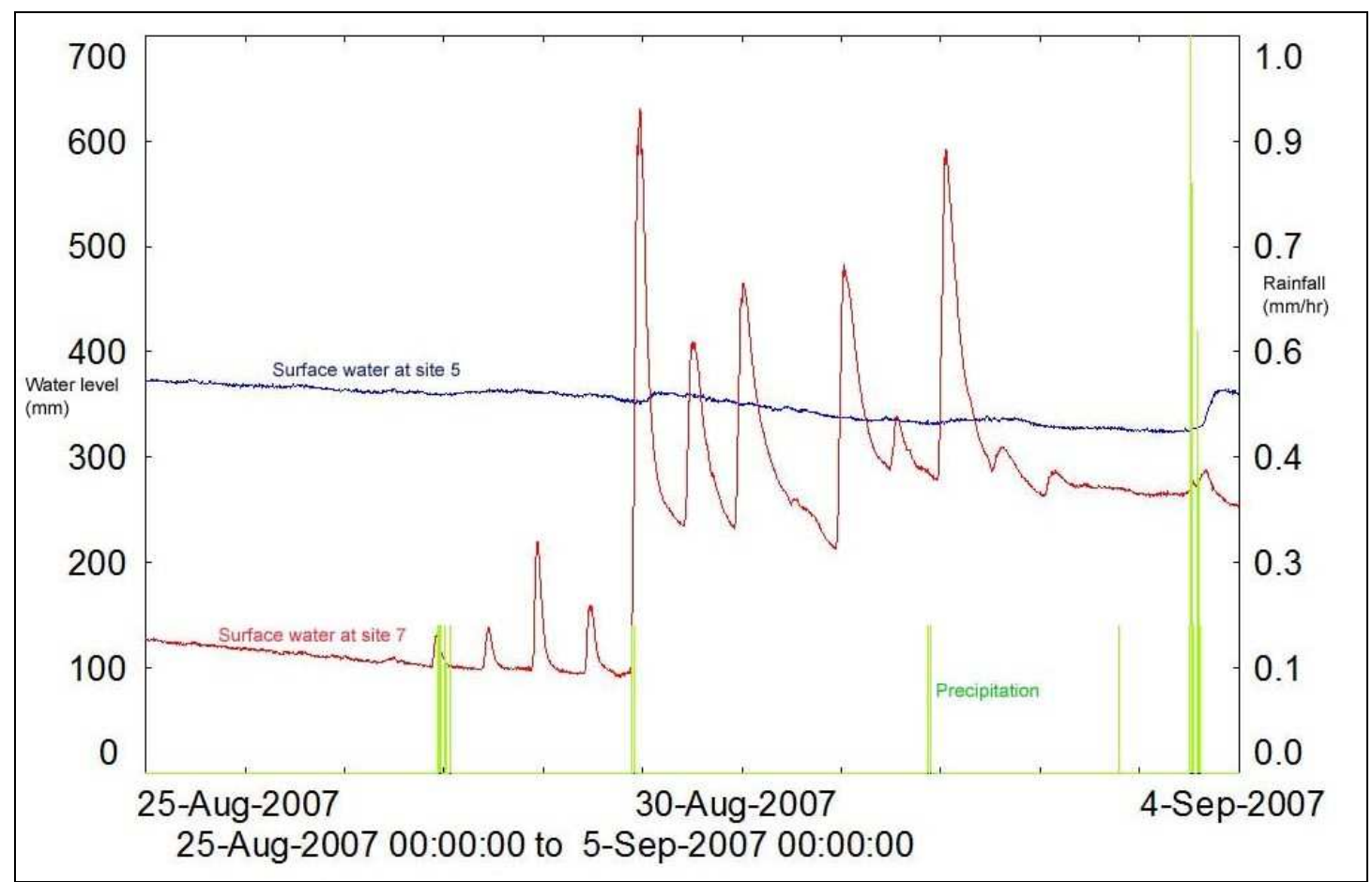

Figure 5.5 Peaks in surface water level at site 7 as a result of high tide. 
Table 5.4 Tidal heights and times (August 25 - September 4 2007) and the influence as seen at site seven

Port Taranaki Waikanae River Site seven

\begin{tabular}{|c|c|c|c|c|c|c|c|}
\hline Date & Tide & Times & $\begin{array}{l}\text { Height } \\
\text { (m) }\end{array}$ & Times & $\begin{array}{l}\text { Height } \\
\text { (m) }\end{array}$ & Time* & $\begin{array}{l}\text { Height } \\
\text { (m) }\end{array}$ \\
\hline \multirow[t]{2}{*}{ Aug 25} & HW & $\begin{array}{l}\text { 7:09am } \\
\text { 7:04pm }\end{array}$ & $\begin{array}{l}2.7 \\
3.0\end{array}$ & $\begin{array}{l}\text { 7:17am } \\
7: 48 \mathrm{pm}\end{array}$ & $\begin{array}{l}1.41 \\
1.54\end{array}$ & & \\
\hline & LW & $\begin{array}{l}1: 04 \mathrm{am} \\
1: 25 \mathrm{pm}\end{array}$ & $\begin{array}{l}1.2 \\
1.0\end{array}$ & $\begin{array}{l}1: 08 \mathrm{am} \\
1: 29 \mathrm{pm}\end{array}$ & $\begin{array}{l}0.78 \\
0.70\end{array}$ & & \\
\hline \multirow[t]{2}{*}{ Aug 26} & HW & $\begin{array}{l}: 02 \mathrm{am} \\
8: 24 \mathrm{pm}\end{array}$ & $\begin{array}{l}2.9 \\
3.2\end{array}$ & $\begin{array}{l}\text { 8:10am } \\
8: 32 \mathrm{pm}\end{array}$ & $\begin{array}{l}1.49 \\
1.62\end{array}$ & & \\
\hline & LW & $\begin{array}{l}1: 56 \mathrm{am} \\
2: 14 \mathrm{pm}\end{array}$ & $\begin{array}{l}0.9 \\
0.8\end{array}$ & $\begin{array}{l}2: 00 \mathrm{am} \\
2: 18 \mathrm{pm}\end{array}$ & $\begin{array}{l}0.66 \\
0.61\end{array}$ & & \\
\hline \multirow[t]{2}{*}{ Aug 27} & HW & $\begin{array}{l}\text { 8:47am } \\
9: 05 \mathrm{pm}\end{array}$ & $\begin{array}{l}3.2 \\
3.4\end{array}$ & $\begin{array}{l}\text { 8:55am } \\
9: 13 \mathrm{pm}\end{array}$ & $\begin{array}{l}1.62 \\
1.70\end{array}$ & $10: 16 \mathrm{pm}$ & +0.024 \\
\hline & LW & $\begin{array}{l}2: 40 \mathrm{am} \\
2: 57 \mathrm{pm}\end{array}$ & $\begin{array}{l}0.7 \\
0.6 \\
\end{array}$ & $\begin{array}{l}2: 44 \mathrm{am} \\
3: 01 \mathrm{pm} \\
\end{array}$ & $\begin{array}{l}0.57 \\
0.53 \\
\end{array}$ & & \\
\hline \multirow[t]{2}{*}{ Aug 28} & HW & $\begin{array}{l}9: 29 \mathrm{am} \\
9: 44 \mathrm{pm} \\
\end{array}$ & \begin{tabular}{|l|}
3.4 \\
3.6 \\
\end{tabular} & $\begin{array}{l}\text { 9:37am } \\
9: 52 \mathrm{pm} \\
\end{array}$ & $\begin{array}{l}1.70 \\
1.79 \\
\end{array}$ & $\begin{array}{l}10: 27 \mathrm{am} \\
10: 19 \mathrm{pm}\end{array}$ & $\begin{array}{r}+0.033 \\
+0.107 \\
\end{array}$ \\
\hline & LW & $\begin{array}{l}3: 21 \mathrm{am} \\
3: 37 \mathrm{pm} \\
\end{array}$ & $\begin{array}{l}0.5 \\
0.4 \\
\end{array}$ & $\begin{array}{l}3: 25 \mathrm{am} \\
3: 41 \mathrm{pm}\end{array}$ & $\begin{array}{l}0.49 \\
0.45 \\
\end{array}$ & & \\
\hline \multirow[t]{2}{*}{ Aug 29} & HW & $\begin{array}{l}10: 09 \mathrm{am} \\
10: 24 \mathrm{pm}\end{array}$ & $\begin{array}{l}3.5 \\
3.7\end{array}$ & $\begin{array}{l}10: 17 \mathrm{am} \\
10: 32 \mathrm{pm}\end{array}$ & $\begin{array}{l}1.75 \\
1.83\end{array}$ & $\begin{array}{l}11: 09 \mathrm{am} \\
11: 21 \mathrm{pm}\end{array}$ & $\begin{array}{r}+0.054 \\
+0.528\end{array}$ \\
\hline & LW & $\begin{array}{l}4: 01 \mathrm{am} \\
4: 18 \mathrm{pm}\end{array}$ & $\begin{array}{l}0.3 \\
0.2\end{array}$ & $\begin{array}{l}: 05 \mathrm{am} \\
4: 22 \mathrm{pm}\end{array}$ & $\begin{array}{c}0.4 \\
0.36\end{array}$ & & \\
\hline \multirow[t]{2}{*}{ Aug 30} & HW & $\begin{array}{l}10: 49 \mathrm{am} \\
11: 04 \mathrm{pm}\end{array}$ & $\begin{array}{l}3.6 \\
3.8\end{array}$ & $\begin{array}{l}10: 57 \mathrm{am} \\
11: 12 \mathrm{pm}\end{array}$ & $\begin{array}{l}1.75 \\
1.87\end{array}$ & $12: 11 \mathrm{pm}$ & +0.164 \\
\hline & LW & $\begin{array}{l}4: 42 \mathrm{am} \\
4: 59 \mathrm{pm}\end{array}$ & $\begin{array}{l}0.2 \\
0.2\end{array}$ & $\begin{array}{l}\text { 4:46am } \\
5: 03 \mathrm{pm}\end{array}$ & $\begin{array}{l}0.36 \\
0.36\end{array}$ & & \\
\hline \multirow[t]{2}{*}{ Aug 31} & HW & $\begin{array}{l}11: 31 \mathrm{am} \\
11: 47 \mathrm{pm}\end{array}$ & $\begin{array}{l}3.6 \\
3.7\end{array}$ & $\begin{array}{l}11.39 \mathrm{am} \\
11: 55 \mathrm{pm}\end{array}$ & $\begin{array}{l}1.79 \\
1.83\end{array}$ & 12:03am & +0.228 \\
\hline & LW & $\begin{array}{l}5: 24 \mathrm{am} \\
5: 41 \mathrm{pm}\end{array}$ & $\begin{array}{l}0.1 \\
0.2\end{array}$ & $\begin{array}{l}5: 28 \mathrm{am} \\
5: 45 \mathrm{pm}\end{array}$ & $\begin{array}{l}0.32 \\
0.36\end{array}$ & & \\
\hline \multirow[t]{2}{*}{ Sept 1} & HW & $12: 13 \mathrm{pm}$ & $3.6 \mathrm{~m}$ & $12: 21 \mathrm{pm}$ & 1.79 & $\begin{array}{l}1: 05 \mathrm{am} \\
1: 17 \mathrm{pm}\end{array}$ & $\begin{array}{l}+0.146 \\
+0.038\end{array}$ \\
\hline & LW & $\begin{array}{l}\text { 6:08am } \\
6: 25 \mathrm{pm}\end{array}$ & $\begin{array}{l}0.2 \mathrm{~m} \\
0.3 \mathrm{~m}\end{array}$ & $\begin{array}{l}\text { 6:12am } \\
6: 29 \mathrm{pm}\end{array}$ & $\begin{array}{c}0.36 \\
0.4\end{array}$ & & \\
\hline \multirow[t]{2}{*}{ Sept 2} & HW & $\begin{array}{c}12: 32 \mathrm{am} \\
1: 00 \mathrm{pm}\end{array}$ & $\begin{array}{l}3.5 \mathrm{~m} \\
3.4 \mathrm{~m}\end{array}$ & $\begin{array}{c}12: 40 \mathrm{am} \\
1: 08 \mathrm{pm}\end{array}$ & $\begin{array}{l}1.75 \\
1.70\end{array}$ & $\begin{array}{l}1: 09 \mathrm{am} \\
2: 18 \mathrm{pm}\end{array}$ & $\begin{array}{l}+0.302 \\
+0.017\end{array}$ \\
\hline & LW & $\begin{array}{l}\text { 6:53am } \\
7: 14 \mathrm{pm}\end{array}$ & $\begin{array}{l}0.4 \mathrm{~m} \\
0.5 \mathrm{~m}\end{array}$ & $\begin{array}{l}6: 57 \mathrm{am} \\
7: 18 \mathrm{pm}\end{array}$ & $\begin{array}{l}0.45 \\
0.49\end{array}$ & & \\
\hline \multirow[t]{2}{*}{ Sept 3} & HW & $\begin{array}{l}1: 22 \mathrm{am} \\
1: 52 \mathrm{pm}\end{array}$ & $\begin{array}{l}3.3 \mathrm{~m} \\
3.2 \mathrm{~m} \\
\end{array}$ & $\begin{array}{l}1: 30 \mathrm{am} \\
2: 00 \mathrm{pm}\end{array}$ & $\begin{array}{l}1.66 \\
1.62 \\
\end{array}$ & 2:28am & +0.012 \\
\hline & LW & $\begin{array}{l}\text { 7:21am } \\
8: 10 \mathrm{pm}\end{array}$ & $\begin{array}{l}0.6 \mathrm{~m} \\
0.8 \mathrm{~m}\end{array}$ & $\begin{array}{l}\text { 7:46am } \\
8: 14 \mathrm{pm}\end{array}$ & $\begin{array}{l}0.53 \\
0.61\end{array}$ & & \\
\hline
\end{tabular}

*It was not possible to accurately estimate low tide times and values from Figure 5.7. Therefore, only values and times for high tide were included. Note that not all high tides resulted in a discernable peak in water level at Site $7 . \mathrm{HW}=$ high tide. $\mathrm{LW}=$ low tide. 


\subsubsection{Groundwater flow}

A groundwater contour and flow map (Figure 5.6) was constructed using mean groundwater elevation data ( $\mathrm{m}$ amsl) from Table 5.10. The preferential flow path is in a north-western direction towards the coast. The groundwater flows from areas with high groundwater elevation to areas with lower elevation. Site 1 has the highest mean groundwater elevation of $4.407 \mathrm{~m}$ (amsl), and is located to the eastern side of the wetland. Site 6 has the lowest mean groundwater elevation of $2.153 \mathrm{~m}$ (amsl) and is located to the western side of the wetland.

The Waikanae Oxidation ponds create an area of artificial high groundwater. (This could also be the result of a topographic high or an area of lower permeability). This causes localised differences in groundwater flow paths away from the oxidation ponds to the south and south-west. Generally, the bores surrounding the oxidation ponds are located at higher elevation than those surrounding the wetland. KCDC bore MW2 is located $5.07 \mathrm{~m}$ (amsl), MW3 is 3.59m (amsl) and MW6 is $4.55 \mathrm{~m}$ (amsl). These bores have relatively low groundwater elevations of $2.70 \mathrm{~m}, 2.39 \mathrm{~m}$ and $2.76 \mathrm{~m}$ respectively when compared to their topographic elevation and the levels found in the other GW bores. 


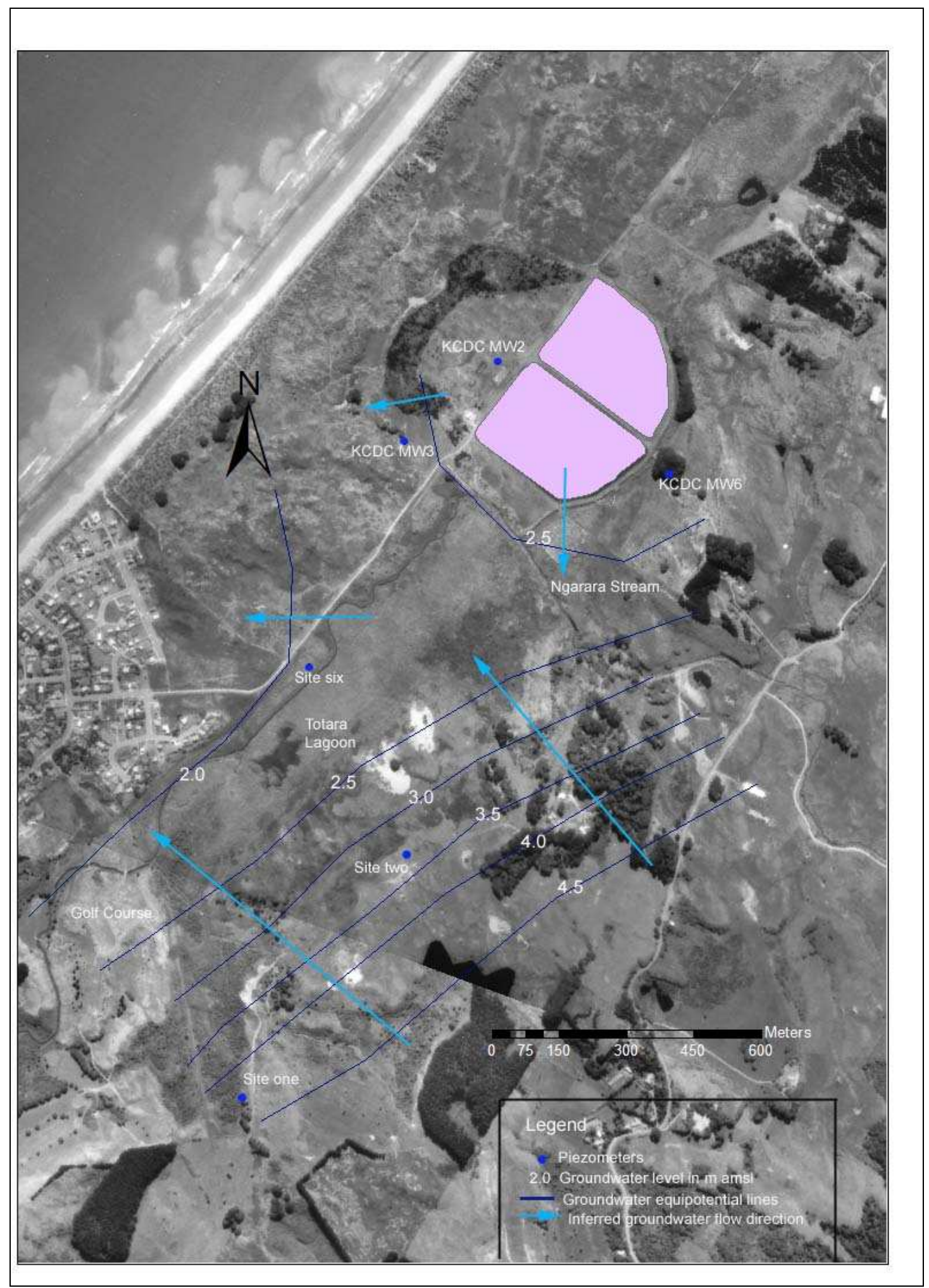

Figure 5.6 Groundwater levels and flow direction in the shallow unconfined dunesand, Te Harakiki wetland. 


\subsubsection{Soil moisture}

Soil moisture at shallow levels at Site 1 respond rapidly to any precipitation event. The TDR at $40 \mathrm{~cm}$ depth shows a short time to rise, which closely correlates to rainfall. Peak moisture content is around $0.42 \mathrm{ml} / \mathrm{ml}$. A similar pattern of response is seen in all the shallow TDR down to $60 \mathrm{~cm}$ (Figure 5.8). The TDRs at 80 and $100 \mathrm{~cm}$ are not affected by additional water entering the soil profile as they are already at saturation $(0.48 \mathrm{ml} / \mathrm{ml})$

Peaks in the groundwater level occur approximately 13 hours after the initial peak in shallow soil moisture levels. Groundwater levels continue to rise about 5 days after the rainfall event. The water table surrounding Te Harakiki is approximately $1 \mathrm{~m}$ below the ground surface. Water moves through the soil profile at approximately $0.077 \mathrm{~m} / \mathrm{hr}$ (or $1.8 \times 10^{-3} \mathrm{~m} /$ day).

Soil moisture contents at 20 and $40 \mathrm{~cm}$ increase rapidly following major rainfall events. The profile, however, takes longer to drain at $20 \mathrm{~cm}$ (6 hours) than at $40 \mathrm{~cm}(4$ hours). The progression of the wetting front (percolation) through the soil profile can be traced using the lag times between peaks in water content at different depths in the profile. The average lag time of peaks between 20 and $40 \mathrm{~cm}$ depths in the soil profile is 35 minutes. The permeability of the soil profile is $0.005 \mathrm{~m} / \mathrm{sec}$. Peaks $1 \mathrm{a}$ and $1 \mathrm{~b}$ have a lag time of 1 hour 10 minutes, peaks 2 and 3 seem to occur simultaneously at both depths and peaks 4 and 5 share a lag time of 35 minutes.

The response of moisture content decreases with depth. The lag time from 40 to $60 \mathrm{~cm}$ depth in the soil profile is greater than between 20 and $40 \mathrm{~cm}$, averaging at 2 hours and 40 minutes. Only peaks 1a (3 hours 30 minutes) and 2 (1 hour 45 minutes) were obvious enough to trace to lower depths, peaks 3, 4, and 5 are not apparent at $60 \mathrm{~cm}$ or deeper. The hydraulic conductivity of the soil varies with depth. 


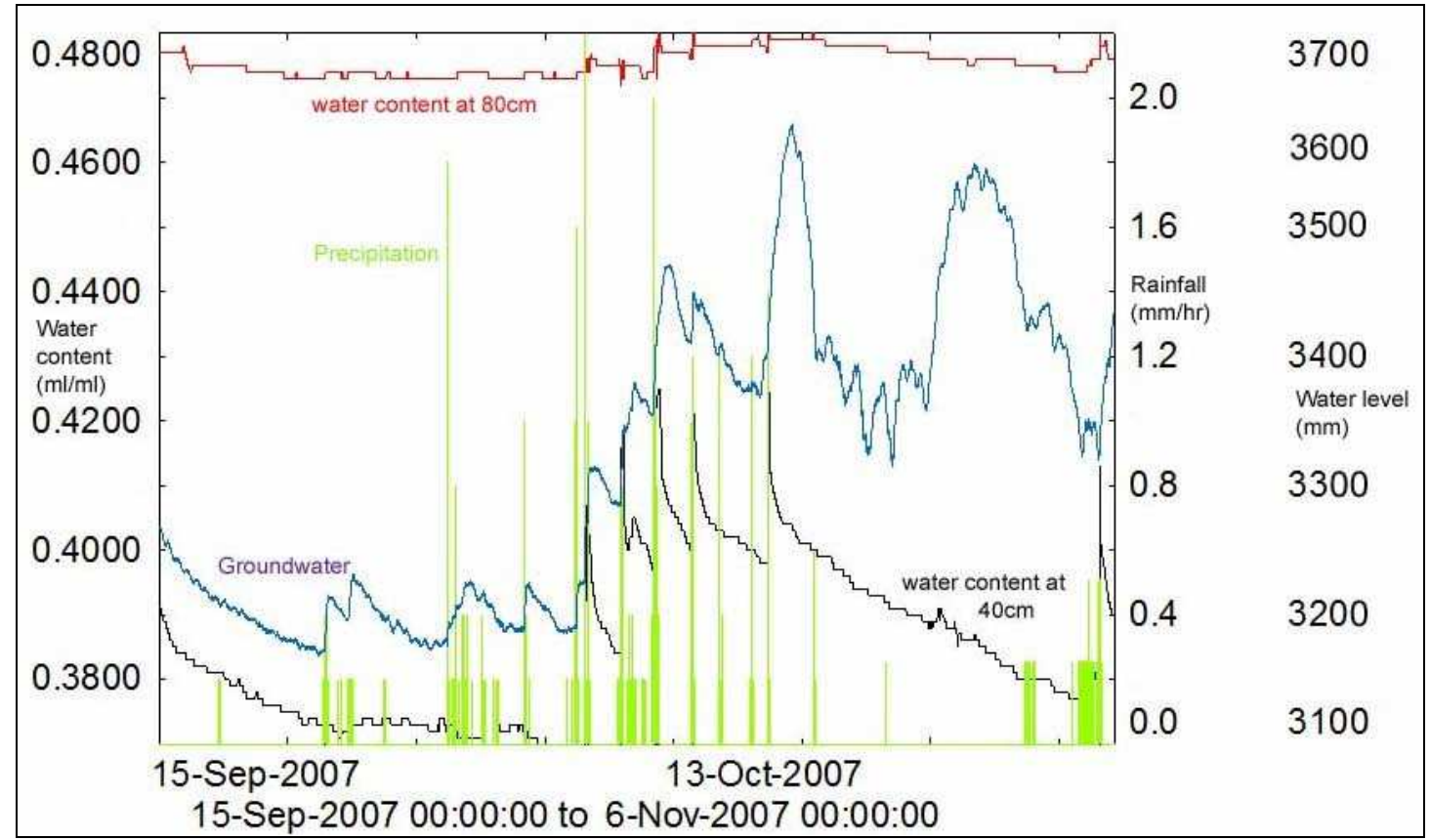

Figure 5.7 The response of groundwater and soil moisture levels at 40 and $80 \mathrm{~cm}$ at Te Harakiki to a rainfall event.

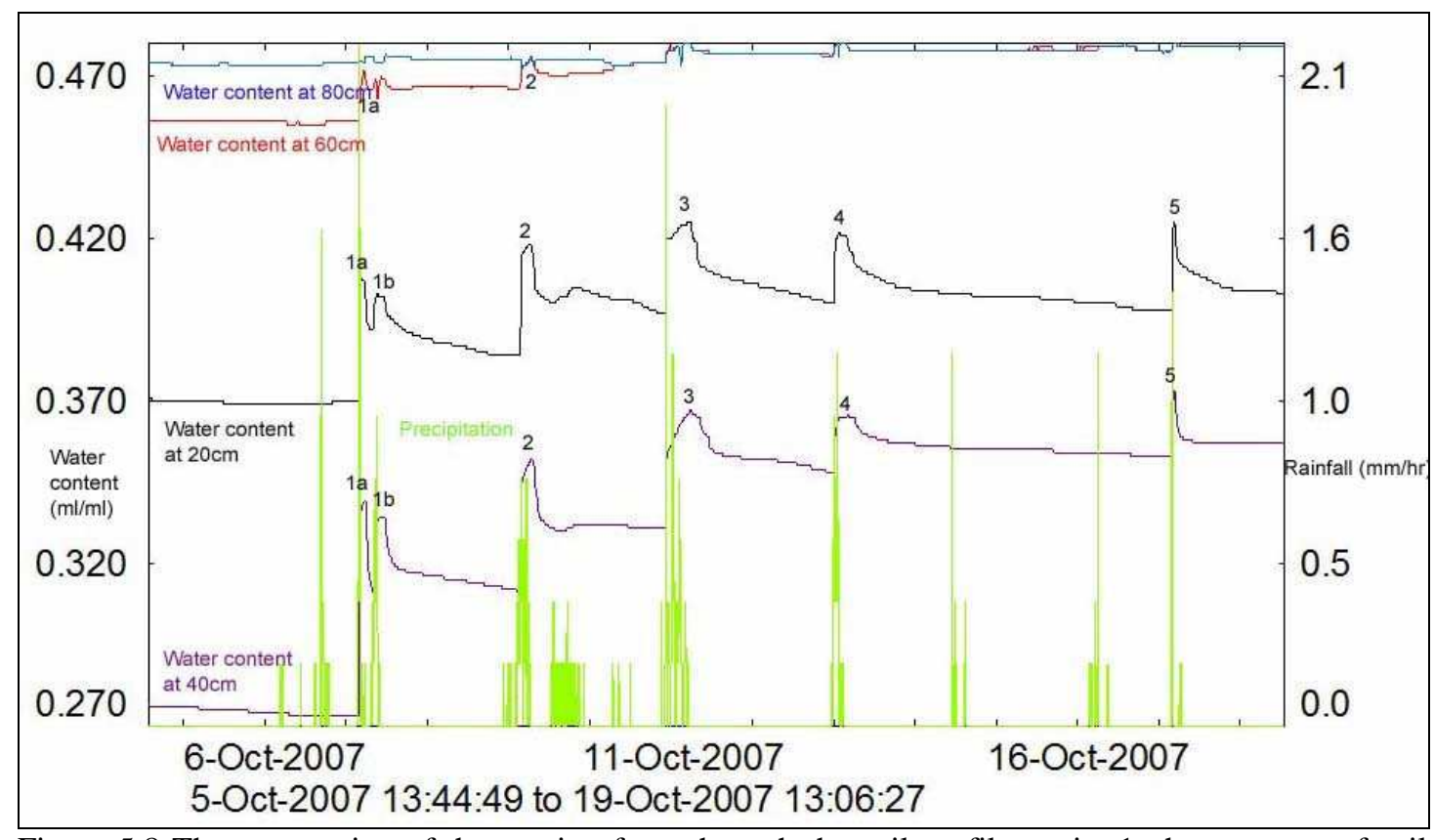

Figure 5.8 The progression of the wetting front through the soil profile at site 1, the response of soil moisture levels at 20,40,60 and $80 \mathrm{~cm}$ to a precipitation event. Traceable peaks in water content are marked $1 \mathrm{a}, 1 \mathrm{~b}$, and 2 through to 5 . 


\section{3: Water Balance}

To better understand the hydrology of Te Harakiki wetland a semi-quantitative water balance was derived. This used monthly data from August through to December (Table 5.5). As a result it is essentially the water balance for winter months and this is why the balance shows a net recharge. A water balance allows the main controls on the hydrology and hydrologic regime to be identified. These can then be managed for future development and/or conservation.

Table 5.5 Cumulative mean water balance for Te Harakiki (5 months)

\begin{tabular}{|c|c|c|}
\hline & In $\left(\mathrm{m}^{3} /\right.$ day $)$ & Out $\left(\mathrm{m}^{3} /\right.$ day $)$ \\
\hline Precipitation & 672 & -- \\
\hline Evapotranspiration & -- & 1,068 \\
\hline Surface water & $86.6^{*}$ & 740 \\
\hline Groundwater & 1,427 & 184 \\
\hline Total & $2,185.6$ & 1,992 \\
\hline TOTAL (in - out) & 194.6 & \\
\hline
\end{tabular}

* This takes into account the two months when there was surface water discharge from the wetland rather than surface water recharge. Note: This is an average water balance for the period covered (August - December 2007).

\subsubsection{Climate analysis}

The mean precipitation rate for the entire period from Site 7 is $2.2 \mathrm{~mm} /$ day. This equates to a daily average input of $672 \mathrm{~m}^{3} /$ day, assuming a wetland area of $30 \mathrm{ha}$. The mean reference potential evapotranspiration rate for the period calculated using the FAO Penman-Monteith equation is $3.6 \mathrm{~mm} /$ day (Table 5.6). This equates to $1,068 \mathrm{~m}^{3} /$ day, assuming the same wetland area.

Precipitation contributes $31 \%$ of the total daily water inflows into the wetland. Evapotranspiration accounts for $54 \%$ of the total daily water outflows while surface water outflow (groundwater discharge) is equal to $37 \%$ water outflows. The total water inflows of $2,185.6 \mathrm{~m}^{3} /$ day are greater than the total outflows from the system. $91 \%$ of total water inflows exit the system as outflows. 
Mean annual rainfall records from 1960 to 2006 from Paraparaumu Airport were assessed to provide a comparison with the study period (Appendix 4). Between 1966 and 1978, eight years had less than average rainfall. Five of the years fell in succession (1969 and 1973) and received (on average) 221.6mm less rainfall than in a normal year. There was a significant decrease in wetland extent during this period (Figure 5.9).

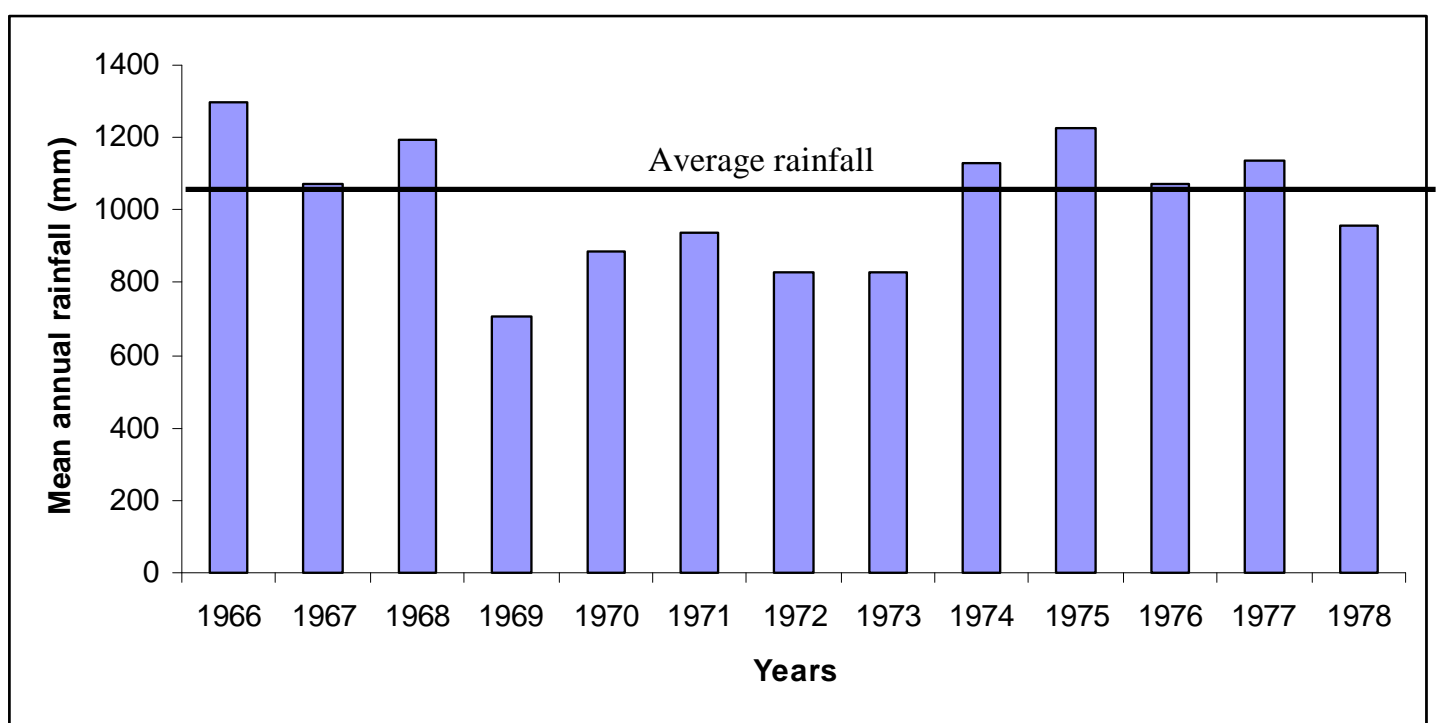

Figure 5.9 Mean annual rainfall for the Paraparaumu area 1966-1978. The threshold line shows the average rainfall for the period.

The eight years between 1978 and 1986 fluctuated between wetter and drier than normal. The wettest year was 1980 , when $1408.5 \mathrm{~mm}$ of rain was received $(372.5 \mathrm{~mm}$ above average). The driest year was 1981 which was $136.7 \mathrm{~mm}$ drier than normal. The period between 1986 and 1996 saw two periods of drier years, each lasting three years 1987 - 1989 and 1992 - 1994. The period between 1996 and 2002 saw more normal rainfall amounts, interspersed with drier years in 1997, 1999 and 2000 (Figure 5.10). The wetland decreased in extent during the periods covered except for between 1996 and 2002 when there was a slight increase in wetland size. 


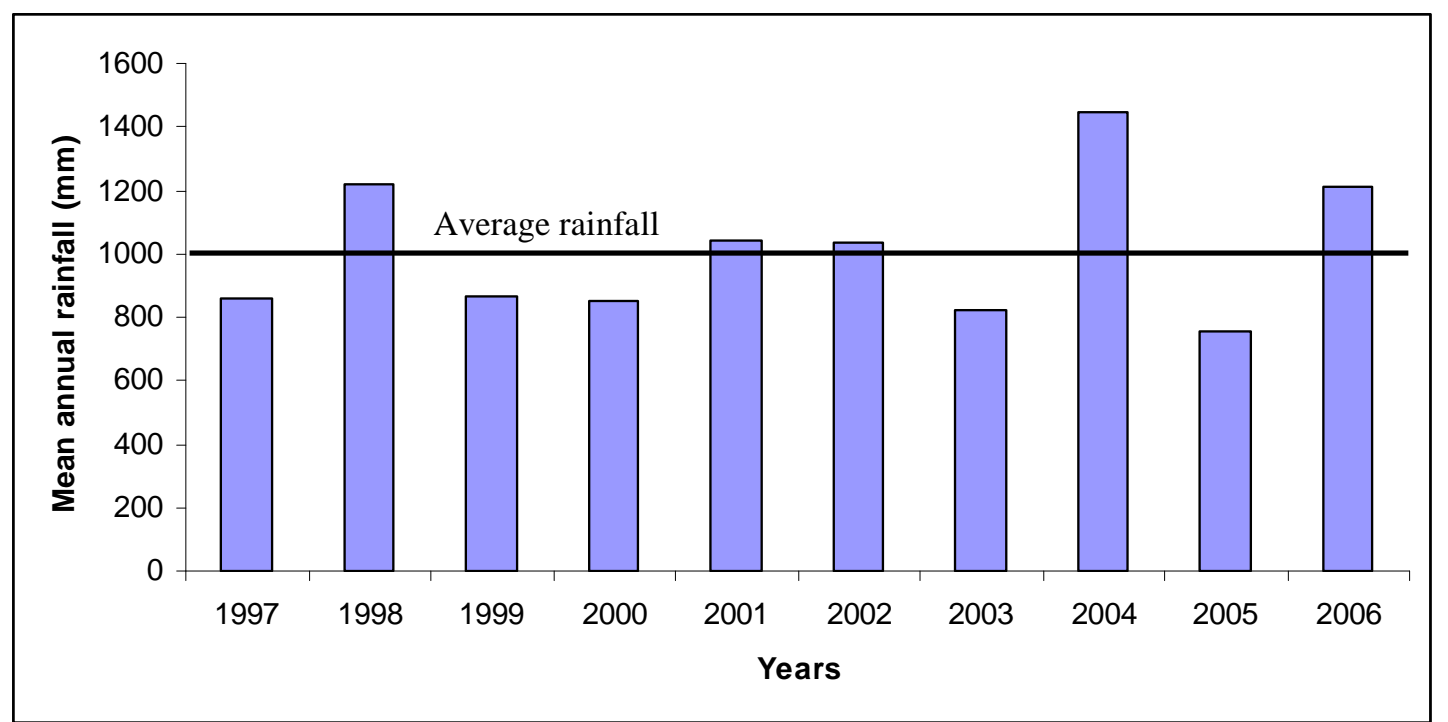

Figure 5.10 Mean annual rainfall for the Paraparaumu area 1996 - 2006. The threshold line shows the average rainfall for the period.

Evapotranspiration data from the same period and location were also analysed. Potential evapotranspiration values were calculated using the Priestley - Taylor (1972) method, as many years did not have measurements for all the climatic variables needed for the FAO Penman - Monteith method. The average rate of evapotranspiration from Te Harakiki for the period 1960 - 2006 was $611 \mathrm{~m}^{3} / \mathrm{day}$. It ranged from $554 \mathrm{~m}^{3} /$ day in 1992 to $659 \mathrm{~m}^{3} /$ day (over the 30ha wetland area) in 1962. Although the Priestly - Taylor method was used for the historical data, the Penman Monteith equation was used for to calculate potential evapotranspiration for the study period. The Priestly - Taylor method for evapotranspiration requires less physical (meteorological) factors than the Penman - Monteith method. The Priestly - Taylor method under-estimates evapotranspiration when compared to the PM method. This means that the rates estimated for historical data are lower than those estimated for the study period. 
Table 5.6 Monthly daily averages of the components required to calculate evapotranspiration using the FAO Penman-Monteith Method with the calculated evapotranspiration rates.

\begin{tabular}{|c|c|c|c|c|c|c|}
\hline & August & September & October & November & December & Average \\
\hline $\begin{array}{c}\mathrm{R}_{\mathrm{n}}\left(\mathrm{MJ} \mathrm{m} \mathrm{m}^{-2}\right. \\
\left.\mathrm{dy}^{-1}\right)\end{array}$ & 6.7 & 9.6 & 11.7 & 14.7 & 13.8 & 11.3 \\
\hline $\mathrm{u}_{2}\left(\mathrm{~m} \mathrm{~s}^{-1}\right)$ & 5.0 & 5.6 & 6.7 & 5.3 & 4.8 & 5.5 \\
\hline $\mathrm{T}_{\max }{ }^{\circ} \mathrm{C}$ & 13.7 & 15.5 & 15.6 & 17.9 & 21.1 & 16.8 \\
\hline $\mathrm{T}_{\min }{ }^{\circ} \mathrm{C}$ & 6.7 & 7.7 & 9.5 & 9.6 & 12.3 & 9.2 \\
\hline$e_{s}-e_{a}(k P a)$ & 0.318 & 0.416 & 0.441 & 0.460 & 0.590 & 0.445 \\
\hline$\gamma\left(\mathrm{kPa}^{\circ}{ }^{\circ} \mathrm{C}^{-1}\right)$ & 0.067 & 0.067 & 0.067 & 0.067 & 0.067 & 0.067 \\
\hline$\Delta(\mathrm{kPa})$ & 0.084 & 0.091 & 0.096 & 0.103 & 0.139 & 0.103 \\
\hline $\mathrm{ET}_{0}\left(\mathrm{~mm} \mathrm{day}^{-1}\right)$ & 3.45 & 4.3 & 4.1 & 4.0 & 3.4 & 3.83 \\
\hline
\end{tabular}

$\mathrm{R}_{\mathrm{n}}=$ net radiation. $\mathrm{u}_{2}=$ wind speed at $2 \mathrm{~m}$ above ground level. $\mathrm{T}_{\max }=$ maximum daily temperature. $\mathrm{T}_{\min }$ $=$ minimum daily temperature. $\mathrm{e}_{\mathrm{s}}-\mathrm{e}_{\mathrm{a}}=$ vapour pressure deficit. $\gamma=$ psychrometric constant. $\Delta=$ slope vapour pressure curve. $\mathrm{ET}_{0}=$ daily reference evapotranspiration rate

\subsubsection{Surface water}

Ngarara Stream transverses Te Harakiki carrying water through the wetland. Phreatos (2002) found that the stream interacts readily with the shallow groundwater system. At various places it either looses (recharges the wetland) or gains (groundwater discharges into the stream) water as it flows through the wetland. It was found that the stream was generally effluent and receiving discharge from groundwater. The gaugings were conducted in autumn (March and April). With no background gaugings to compare against they just reflect the conditions in the stream for this point in time.

While it is highly likely that the surface and groundwater systems do interact, and alternate between recharge and discharge, the effects of tides were not taken into account in earlier studies. Flow at Site 7 is obviously affected by tides. It is likely that 
this factor accounts for some of the "discharge from groundwater" in the Phreatos (2002) study. Surface water inflow is an important part of the water balance and has been included in this study. During some parts of the year surface water inflow supplies over $50 \%$ of inflows to the wetland. At other times it is negative removing $50 \%$ of inflows. On average surface water inflow contributes $4 \%$ of the total inflows to Te Harakiki.

Table 5.7 Ngarara Stream flow measurements (monthly mean)

\begin{tabular}{|c|c|c|c|c|c|c|}
\hline \multirow{2}{*}{ Location } & \multicolumn{6}{|c|}{ Measured Discharge (L/sec) } \\
\hline & August & September & October & November & December & $\begin{array}{c}\text { Error } \\
(\%)\end{array}$ \\
\hline $\begin{array}{c}\text { Site } 3 \text { - Ngarara Stream enters } \\
\text { wetland }\end{array}$ & 65 & 45 & 95 & 70 & 39 & 13.6 \\
\hline $\begin{array}{l}\text { Site } 7 \text { - Ngarara stream exits } \\
\text { wetland at Golf Course }\end{array}$ & 51 & 20 & $110^{*}$ & 68 & $60^{*}$ & 25.2 \\
\hline $\begin{array}{l}\text { Approximate loss to } \\
\text { groundwater** }\end{array}$ & 14 & 25 & +15 & 2 & +21 & \\
\hline
\end{tabular}

*The effects of high tides should be considered here.

** or storage in the wetland

Although the discharge at Site 7 is generally below that recorded at Site 3 (Figures 5.5 and 5.9), during October and December it recorded higher flows (based on the rating curves constructed for each site). Discharge at Site 7 is larger for lower stage heights than recorded at Site 3 (Figures 5.11 and 5.12).

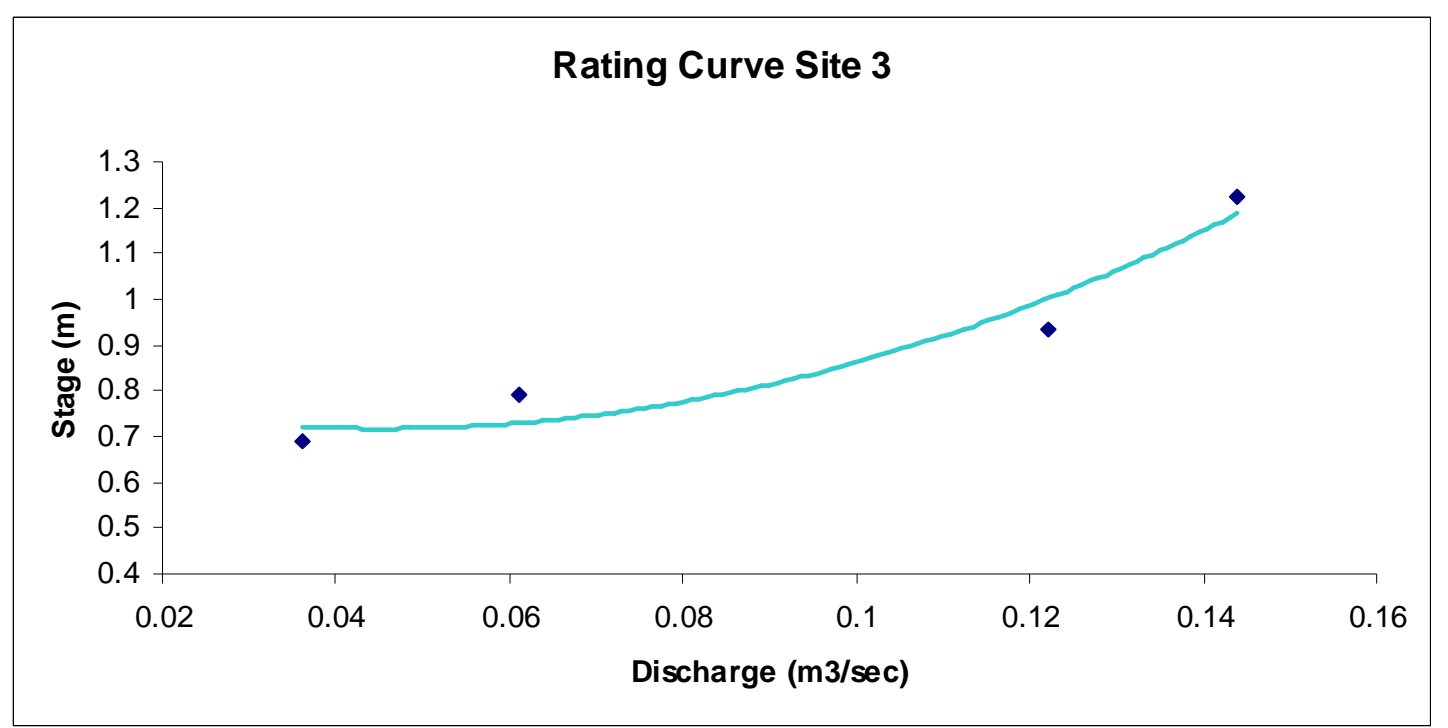

Figure 5.11 Rating curve for Site 3 


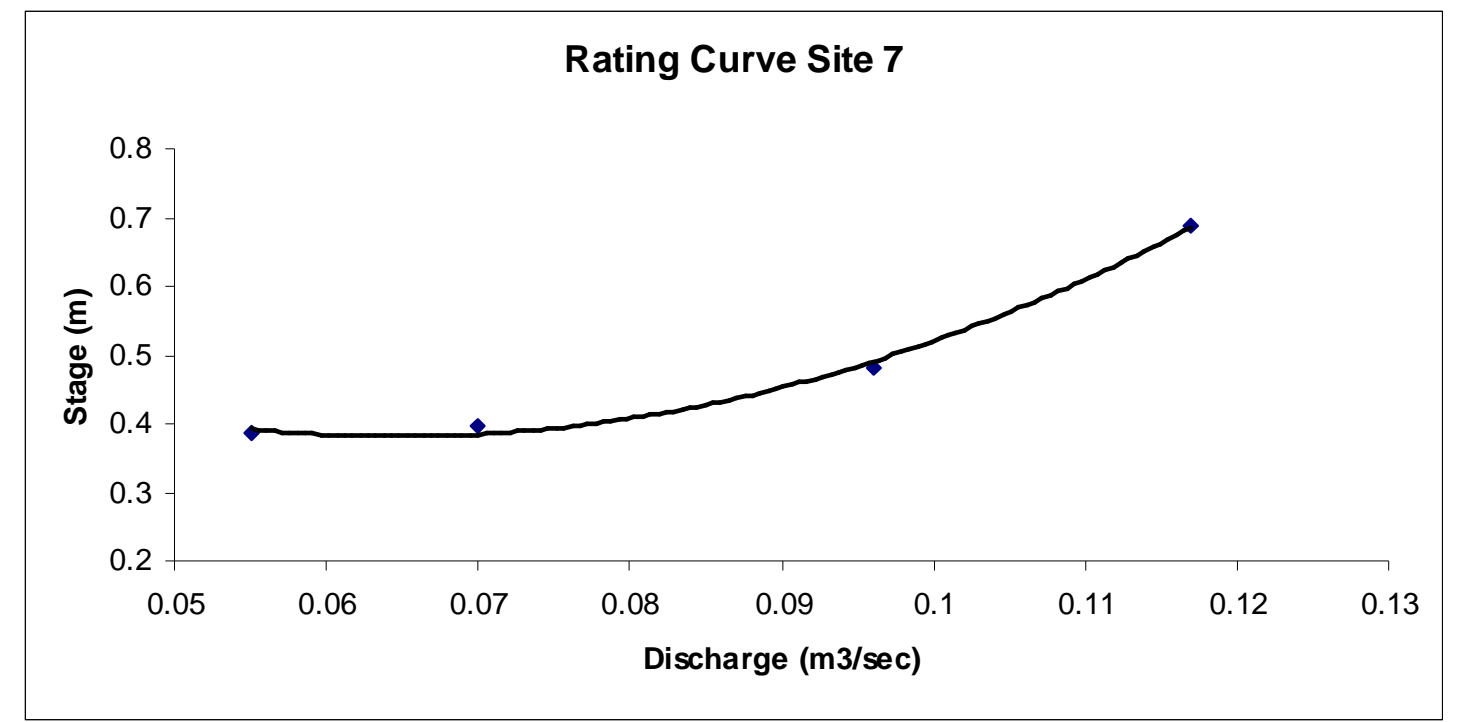

Figure 5.12 Rating curve for Site 7

The rating curve constructed for Site 7 could be inaccurate because of tidal flow and its effects. The higher discharges recorded at the site could be caused by backflow as the tide either advances or recedes down the stream channel. It may not be caused by groundwater discharge as proposed by Phreatos (2002). This could also account for the higher errors associated with gauging method used at this site.

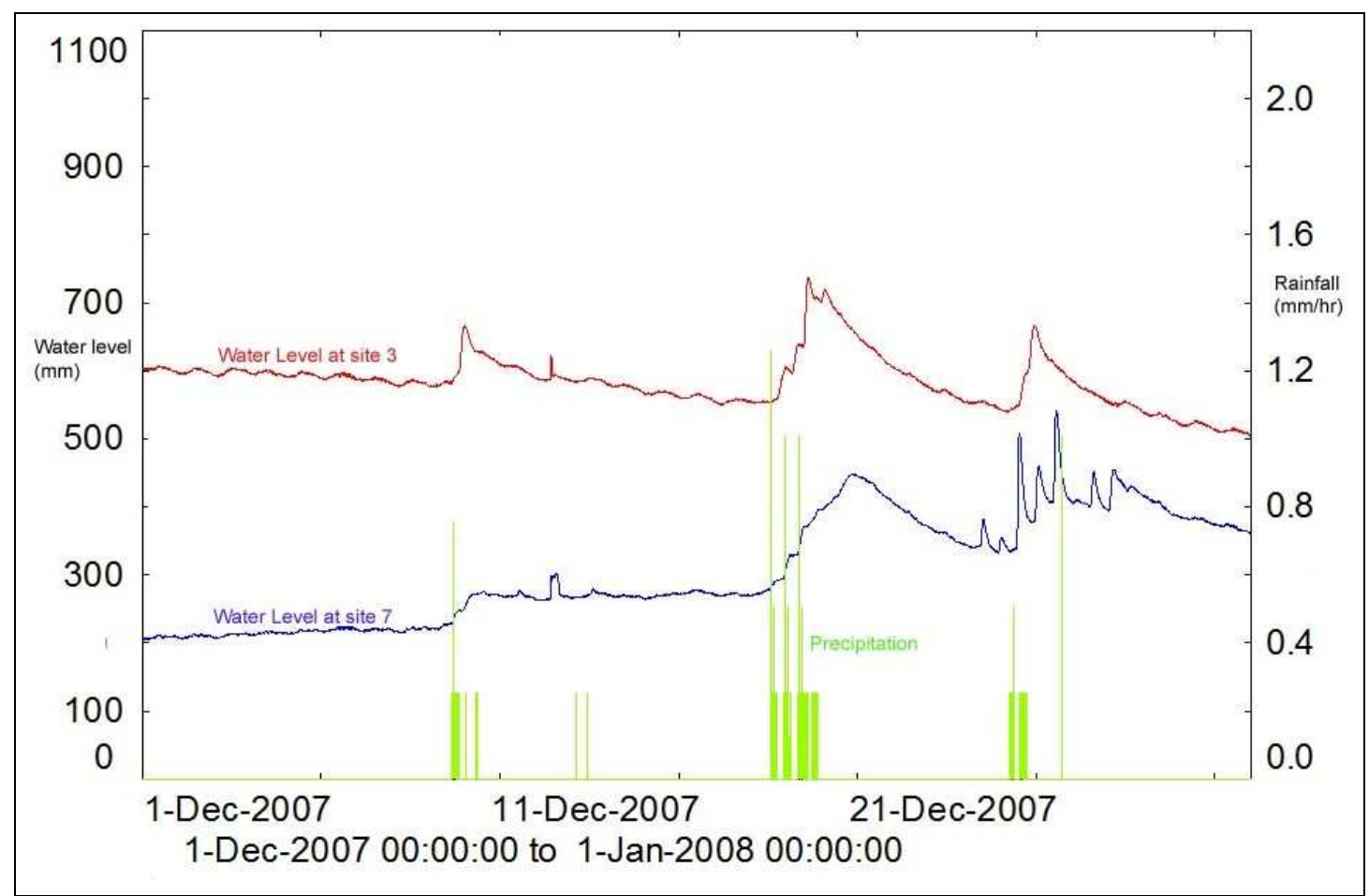

Figure 5.13 Comparison of water level at sites three and seven for December 2007. 
Surface water outflow (groundwater discharge to the stream) ranged from $420 \mathrm{~m}^{3} /$ day in November to $1,620 \mathrm{~m}^{3} /$ day in September. An excess flow from the wetland occurred in every month except October. During October higher flow levels in the stream, as a result of large amounts of precipitation, led to an extra $620 \mathrm{~m}^{3} /$ day being recharged to groundwater. The time constraints on this study meant that data from only winter and spring were used, the results may differ over summer. On average surface water outflow provided $37 \%$ of total water losses from the system.

Both surface water inflow and surface water outflow for October returned negative numbers. The surface water inflow (recharge) was calculated at $-1,290 \mathrm{~m}^{3} /$ day (or 1 , $290 \mathrm{~m}^{3} /$ day groundwater discharge). The surface water outflow (discharge) was calculated at $-620 \mathrm{~m}^{3} /$ day (or $620 \mathrm{~m}^{3} /$ day recharge to groundwater). As the surface water and shallow groundwater systems are closely linked, water is exchanged readily from one to the other. Ngarara stream switches from an influent to an effluent stream depending on the hydrological conditions. The surface water inflow is likely to have been under-estimated because of the effects of tides on the recorder at Site 7.

Table 5.8 Surface water outflow

\begin{tabular}{|c|c|}
\hline Month & $\begin{array}{c}\text { Surface water } \\
\text { outflow }\left(\mathbf{m}^{3} / \text { day }\right.\end{array}$ \\
\hline August & 820 \\
\hline September & 1,620 \\
\hline October & -620 \\
\hline November & 420 \\
\hline December & 1,460 \\
\hline
\end{tabular}

\subsubsection{Groundwater}

Groundwater inflow to the wetland is an important aspect of the water balance as the area is characterised by regional groundwater discharge. Groundwater enters the wetland by flowing laterally from the surrounding dunes, and vertically from the underlying shallow sand aquifer (Phreatos, 2002). 
Groundwater inflow was calculated using Darcy's Law. The hydraulic conductivity (from Phreatos, 2002) for Site 6 (Taupo Dunesand) in Table 5.9 is $1.3 \mathrm{~m} / \mathrm{day}$. The measured average hydraulic gradient ranged from $3 \times 10^{-3}$ to $4.4 \times 10^{-3}$ (the gradient varied slightly from month to month). The wetland area was 30ha. The estimated average groundwater inflow to the wetland was $1,427 \mathrm{~m}^{3} /$ day. Groundwater inflow makes up $65 \%$ of the total water inflows to the wetland system.

Groundwater outflow is the throughflow to the coast along the western edge of the wetland. The average daily groundwater outflow was also estimated using Darcy's Law. Using the hydraulic conductivity of Waiterere Dunesand (4.2m/day), a hydraulic gradient of $3 \times 10^{-3}$ to $4.4 \times 10^{-3}$, and an area of $12000 \mathrm{~m}^{2}(1200 \mathrm{~m} \times 10 \mathrm{~m}$ depth (assumed)) gave a groundwater outflow of $184 \mathrm{~m}^{3} / \mathrm{day}$. Groundwater outflow contributes $9 \%$ to the total losses from the system.

Table 5.9 Hydraulic conductivity of piezometers at Te Harakiki

\begin{tabular}{|c|c|c|}
\hline Piezometer & Formation & $\begin{array}{c}\text { Hydraulic Conductivity } \\
\text { (m/day) }\end{array}$ \\
\hline Site 1 & Foxton Dunesand & 5.7 \\
\hline Site 2 & Waiterere Dunesand & 4.2 \\
\hline Site 6 & Taupo Dunesand & 1.3 \\
\hline
\end{tabular}

Source: Phreatos, 2002 p 8.

Table 5.10 Groundwater level monitoring

\begin{tabular}{|c|c|c|c|c|c|c|c|}
\hline \multirow[t]{3}{*}{ Piezometer } & \multirow{3}{*}{$\begin{array}{l}\text { Elevation } \\
\text { (top of } \\
\text { casing) m } \\
\text { amsl }\end{array}$} & \multirow[b]{3}{*}{ August } & \multirow{2}{*}{\multicolumn{3}{|c|}{ Groundwater Elevation (m amsl) }} & \multirow[b]{3}{*}{ December } & \multirow[b]{3}{*}{ Average } \\
\hline & & & & & & & \\
\hline & & & September & October & November & & \\
\hline Site 1 & $4.764^{*}$ & 4.451 & 4.356 & 4.428 & 4.392 & -- & 4.407 \\
\hline Site 2 & $4.405^{\star}$ & 3.285 & 3.211 & 3.403 & 3.325 & 3.121 & 3.269 \\
\hline Site 6 & $2.876^{*}$ & 2.155 & 2.079 & 2.309 & 2.203 & 2.019 & 2.153 \\
\hline $\begin{array}{c}\mathrm{KCDC} \\
\mathrm{MW2}\end{array}$ & $5.07^{*}$ & -- & -- & -- & -- & -- & $2.700^{*}$ \\
\hline $\begin{array}{c}\text { KCDC } \\
\text { MW3 }\end{array}$ & $3.59^{*}$ & -- & -- & -- & -- & -- & $2.390^{*}$ \\
\hline $\begin{array}{l}\text { KCDC } \\
\text { MW6 }\end{array}$ & $4.55^{*}$ & -- & -- & -- & -- & -- & $2.760^{*}$ \\
\hline
\end{tabular}

* Data from Phreatos (2002) p 8 


\section{4: Groundwater abstraction}

Jones and Baker (2005) modelled the shallow groundwater on the Kapiti Coast. They assessed the effects of garden irrigation abstractions from the shallow sand aquifer on groundwater dependant ecosystems. Their modelling showed that stream and wetland levels should be unaffected by the large number of groundwater users pumping at the rate typical of narrow $(25 \mathrm{~mm})$ diameter wells. However, if pumping rates exceeded $100 \mathrm{~m}^{3} /$ day near a wetland or spring-fed stream, this may adversely affect these features.

Figure 5.14 illustrates the modelling results for water level in Te Harakiki (Jones and Gyopari, 2005). The figure shows little difference in wetland water level under three different abstraction scenarios: no abstraction; current level of abstraction, plus additional abstraction for a proposed subdivision to the west of the wetland; and twice the current level of abstraction.

As groundwater inflow is the major contributor the wetland water balance, (supplying $65 \%$ of inflows) it is important to monitor this resource. Increased groundwater abstraction during the drier periods of the year could have a detrimental effect on wetland extent. 


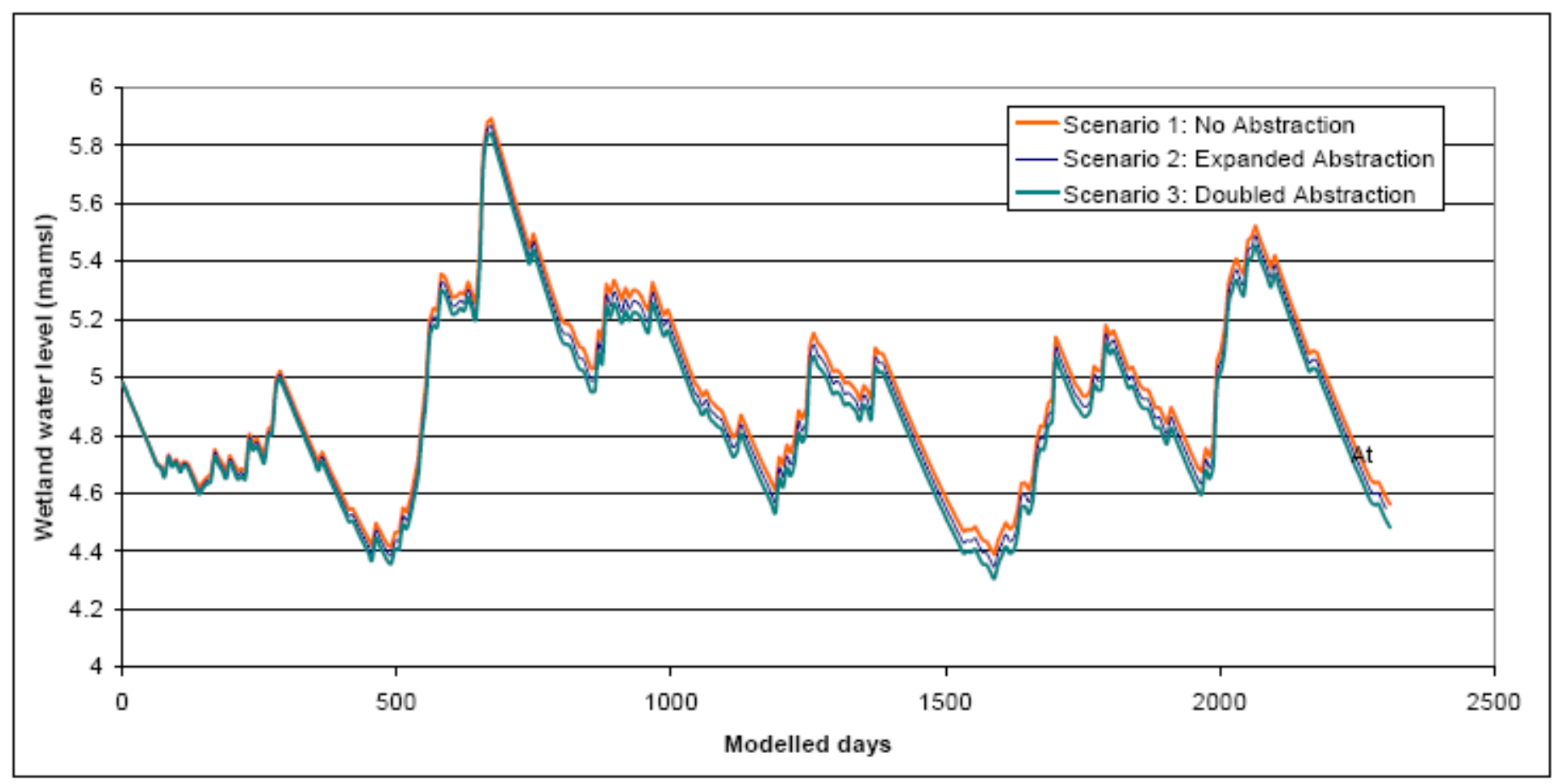

Figure 5.14 Modelled water levels for Te Harakiki Wetland under different abstraction scenarios. Source: Jones and Baker (2005) 


\subsection{Summary}

Understanding the various elements controlling the hydrologic regime of the wetland ecosystem is important for the management and preservation of the system. Analysis of historical aerial photographs from 1966 to 2002 shows a loss of more than $80 \%$ of the wetland. An increase in urbanisation of nearly $60 \%$, and a population increase of $96 \%$, occurred over the same period.

Analysis of hydrometric data showed the dynamic nature of the response of the surface water and shallow groundwater to rainfall events. Surface water responds quickly to events greater than $0.2 \mathrm{~mm} / \mathrm{hr}$. Peak flows can be seen within 30 minutes of the rainfall event. The shallow groundwater shows a similar response but, because of the buffering effect of the overlying soil, it is more subdued.

Tidal effects can be seen in the stream flow as far as $1850 \mathrm{~m}$ from the stream mouth. There is a consistent lag for the effects of the tides to travel from the coast to the recorder at Site 7. The exact effect of specific tides at the recorder is not easily quantified.

The development of a semi-quantitative water balance for Te Harakiki shows that the main contributor to water inflows is precipitation, which accounts for $31 \%$. The main component of water outflow is losses to evapotranspiration at $54 \%$. The effects of tides at Site 7 may have influenced the data calculated for both surface water inflows and outflows. The water balance for Te Harakiki was positive; the inflows are greater than the outflows (by $195 \mathrm{~m}^{3} /$ day) during the period of this study. This means that there is an increase in the amount of water stored within the system. This is to be expected during winter and early spring. Over the summer months (based on the December data) the water balance is negative the outflows are greater than the inflows, decreasing the amount of water in storage for several months. The water balance for Te Harakiki is positive but the level of increase in storage is relatively small. Increased pressures on the system, especially during drier months of the year, could cause the system to move to longer periods of deficit. 


\section{Chapter 6: Discussion}

\section{1: Introduction}

The Te Harakiki Wetland system is maintained by complex interactions between rainfall, surface water and groundwater. The main inflows to the wetland system are precipitation and groundwater. Groundwater is particularly important in maintaining water levels during the summer. Discharge from the wetland occurs as evapotranspiration and seepage into the stream channel.

Historically the area of the wetland has been decreasing (Figures 5.1). Changes in the principal hydrological controls on the system do not seem to account for the large losses in wetland habitat.

\section{2: Hydrological regime and water balance}

The hydroperiod of Te Harakiki is unable to be accurately characterised because of insufficient historical monitoring data. The general state of the system and its central controls, however, can be identified through the water balance.

\subsubsection{Climatic response}

From the water balance (Table 5.5) it is clear that climatic factors are the controlling influences of the hydrological regime of Te Harakiki. Precipitation provides $31 \%$ of total water inflow to the wetland, and evapotranspiration accounts for $55 \%$ of total outflows. The evapotranspiration rate is nearly double the mean daily precipitation.

Some of the decrease in wetland size between 1966 and 1978 could be attributed to a succession of drier than normal years from 1969 to 1973. During this five year period approximately 200mm less rainfall was received each year. Between 1978 and 1986, again, the area of the wetland decreased. During this period dry years were interspersed with wet years, giving above average rainfall for the entire period. The latter two periods (1986 - 1996 and 1996 - 2002) experienced below average rainfall. This may have accounted for some of the loss of open water habitat between 1986 and 
1996, but the wetland area increased between 1996 and 2002; despite experiencing below average rainfall. This indicates that there are other factors, with a stronger influence than precipitation causing the decrease in wetland extent. This is likely to be the combination of the channelisation of Ngarara Stream, which was initiated at the turn of the 20th Century: along with periodic drain clearance for flood control; and increased pressure on the shallow groundwater system because of urban growth.

The decrease in wetland extent can not be explained by increased evapotranspiration. Evapotranspiration has been relatively constant at around $600 \mathrm{~m}^{3} /$ day (over the entire wetland area). The amounts calculated for the study are slightly higher than the historical record, but a different method as used

\subsubsection{Surface water interactions}

Between 1978 and 1986 the Ngarara Stream channel underwent extensive modifications through channelisation and dredging (Figures $5.1 \mathrm{~b}, \mathrm{c}$ ). Many of the natural bends were removed for the development of the Waikanae Beach township. The channel was artificially entrenched and underwent regular dredging as a flood protection measure (Phreatos, 2002). Channelisation and dredging of the stream meant that it now only overtops and sends flood pulses to the wetland during extreme high intensity rainfall events. As the water level of stream is usually below that of the wetland, the amount of surface water recharge is greatly diminished from historical (pre channelisation) levels. The stream now acts as a drain from the wetland rather than a source of recharge.

Surface water inflows to the wetland are minimal (only $4 \%$ of total inflows). They are not a significant part of the water balance for Te Harakiki. The influence of tides on the discharge gaugings conducted at the most downstream site need to be taken into account. This could have skewed the rating curve towards a low stage/high discharge relationship at this point in the stream. The surface water inflow from the stream could be greater than has been estimated. Recharge from the stream could be greater during high tide than low tide because of backwater effects. The influence of surface water inflow may change relative to the tidal cycle. 
Surface water outflow equates to $16 \%$ of water losses from the system. More water is lost from the system as surface water outflow (740m³/day) than is returned as surface inflow. From the calculations made for the water balance, surface water outflows are nearly 800 times greater than the surface water inflows. The inflows only equate to $11 \%$ of outflows. This could be because of the drainage effect of the heavily modified Ngarara Stream channel.

Historically the surface water inflow to the wetland may have played a more significant role in the water balance than at present. As the stream in its natural state would have interacted more with the wetland system, the drainage effect would have been less. Unfortunately, there are no historical stream flow records that allow this comparison to be made. A less entrenched stream channel would also allow more flood pulsing into the wetland system. Having more bends in the stream channel (Figure 5.1 a) as opposed to a straightened channel (Figure $5.1 \mathrm{c}$ ) would also mean that water would have a longer residence time, and therefore more time to penetrate the wetland. Drainage effects would also be decreased.

\subsubsection{Groundwater interactions}

The surface water and shallow groundwater systems within Te Harakiki are closely linked (Figure 5.3). Precipitation events can be traced through peaks in water level in both systems. The groundwater system experiences a longer lag time for flood peaks; and the peaks are more subdued than those seen in the surface water system. This is because of the buffering effect of percolation. On average it takes nearly three hours for rainfall to percolate the soil profile at Te Harakiki to a depth of $60 \mathrm{~cm}$ (Figure 5.8) and it takes a further 10 hours for the percolated water to show as a peak in groundwater level (Figure 5.7).

The majority of the groundwater recharge in the area is through rainfall infiltration. A conservative estimate of recharge to groundwater is approximately $40 \%$ of the total rainfall (Lincoln Environmental, 2001 in Jones and Baker, 2005). The level of recharge through infiltration is dependant upon soil type, geology and land use. The majority of the Te Harakiki catchment is in sandy soil. Land use varies from agriculture to urban. The settlement of Waikanae Beach is located within the Te 
Harakiki catchment area. Watts (2002) showed that approximately $30 \%$ of rainfall is intercepted by urban areas on the Kapiti Coast. This is because increased urbanisation results in decreased groundwater recharge as the rainfall is not able to infiltrate impermeable surfaces, such as footpaths and roads. Instead of infiltrating the soil profile to the water table, the water runs off quickly through artificial channels (gutters and storm water drains). The decrease in infiltration from increased cover of impervious surfaces could be partially offset by increased garden irrigation within the urban setting. This would supply some groundwater recharge.

Groundwater flows into the wetland along the eastern side and flows out towards the coast to the west. Within the water balance, groundwater supplies $65 \%$ of inflows to the wetland system and $9 \%$ of outflows. The level of total groundwater outflow $\left(184 \mathrm{~m}^{3} /\right.$ day $)$ is far smaller than total groundwater inflow $\left(1,427 \mathrm{~m}^{3} /\right.$ day $)$. The groundwater outflow is equal to $12 \%$ of groundwater inflow to the system. As the main water input to the system, groundwater plays an important role in maintaining the moisture levels during the drier summer months.

\section{3: Implications for the management of Te Harakiki}

During this study the water balance for Te Harakiki wetland was positive, providing a daily increase in water stored in the system of around $194.6 \mathrm{~m}^{3} /$ day. The water balance is likely to be negative throughout the summer months. Historically the wetland has been decreasing in size. Rainfall and evapotranspiration records, two of the main controls on the wetland water balance, from 1960 to 2006 do not account for the significant decrease in wetland extent.

\subsubsection{Groundwater abstractions}

There are a large number of shallow wells abstracting water for garden irrigation from the sand aquifer in the Waikanae area. Each of these wells abstracts approximately 1$5 \mathrm{~m}^{3} /$ day (Jones and Gyopari, 2005). The exact number and location of many of the shallow bores along the Kapiti Coast are unknown. Jones and Gyopari (2005) estimated that there are around 3000 bores; by assuming that $50 \%$ of all properties have an irrigation well ( refer to Figure 1.2). This estimate could be conservative. The level of groundwater abstracted from the shallow aquifer by these bores would be 
between 3,000 and 15,000m³/day (Jones and Gyopari, 2005). As the location of most of the bores is unknown, the total level of abstraction from the shallow sand aquifer can only be estimated.

Figure 5.14 showed water level in Te Harakiki wetland under different abstraction scenarios. The abstraction of groundwater from narrow $(25 \mathrm{~mm}$ diameter) garden irrigation bores appears to have little influence on the water levels in the wetland. When modelled at twice the estimated current rate, abstraction scenarios follow the same seasonal trends, and vary at most by only $0.1 \mathrm{~m}$. However, groundwater levels have declined by $0.5 \mathrm{~m}$ within the shallow dunesand. If the decline in groundwater continues, then additional abstraction of the resource will have a detrimental effect on the wetland, particularly during the drier summer months.

\subsubsection{The long term viability of the wetland}

The channelisation and dredging of Ngarara Stream through the wetland undoubtedly resulted in a reduction in water levels at Te Harakiki. As a result of the deepened channel, surface water tends to flow quickly through the wetland, flood pulsing is now a rare, and the channel acts as a drain. The reduction in flow from the Black Drain, seen soon after the decommissioning of the oxidation ponds, is unlikely to have had any significant impact on the wetland. The reduction in the Ngarara Stream baseline stage may have resulted in localised drying adjacent to the stream channel.

Part of the historical loss of wetland area could be attributed to the modification of the stream channel for flood protection. This resulted in changes to the inundation cycle (flooding and drying) of the wetland. Anthropogenic changes to natural cycles within the wetland's hydrological regime can affect the viability of a wetland system. A possible way to ensure the preservation of Te Harakiki would be to revert the stream channel back to a more natural state. Thereby increasing the number of inundation events that occur.

The wetland was fragmented by the construction of the oxidation ponds in the 1970's. The decrease in size of wetland habitat, fragmentation from other wetland areas (many of which were subsequently drained), together with increased urbanisation 
made the Te Harakiki wetland system more vulnerable to encroachment by introduced plant species. A shift in species composition could change the hydrological regime and influence the long term viability of the system.

Between 1996 and 2002 the wetland appears to have started to recover. The lagoon has increased in size by $0.74 \mathrm{~km}^{2}$. The Resource Management Act (1991) saw the implementation of better resource management practices. The recovery seen in the wetland could be the result of improved management practices. As expected, there was a lag before the benefits of the change in practices can be seen in the wetland. For example, the increase in the size of the open water lagoon habitat. The wetland area was fenced off, and stock excluded, just prior to this as part of the requirements of the QE II Open Spaces Covenant. The lack of maintenance of the stream channel during this period may also have been a contributing factor.

During 2000 changes were made to the Regional Freshwater Plan to prevent the over abstraction of groundwater resources. The construction of shallow groundwater bores for domestic or garden irrigation became a consented activity. The concept of safe yields was introduced. This provides better information regarding to the state of the groundwater resource. It also allows the level of abstraction to be better managed for the preservation of the aquifers for future use. The fact that water levels in the shallow dunesand have been declining over recent years is of concern.

It is believed that the wetland has continued to increase in size and recover since 2002. During this time the restoration of Te Harakiki has been enhanced by being part of the Greater Wellington Key Native Ecosystems programme. Introduced pest plant species were identified by an ecological survey of the area by Allen and Beadel (2002). Since then, measures have been made to control pest plants to encourage recolonisation of native wetland species.

Jones and Gyopari (2005) recommended a 150m buffer zone surrounding groundwater dependant ecosystems. Groundwater abstractions would be permitted within the buffer zone, but they would be regulated and monitored to avoid excessive drawdown effects. The creation of a buffer zone such as this around Te Harakiki 
would be a beneficial management measure. It would help ensure the preservation of the wetland.

Climatic factors are among the main controls on the wetland water balance. Unless there is a major shift in climate, resulting in reduced rainfall and/or increased evapotranspiration, the Te Harakiki wetland system should continue to survive. But the management of the shallow groundwater resource, the main contributor to total water inflow, surrounding Te Harakiki will be key to ensuring its survival. If this resource is sustainably managed, the wetland may even be enhanced under the restoration measures that have been put in place. 


\section{Chapter 7 - Summary and Recommendations}

\subsection{Summary}

The Te Harakiki wetland is an ecologically important area. It has been recognised as such by its inclusion in the Greater Wellington Key Native Ecosystems programme. It is also protected under a Queen Elizabeth II covenant. The wetland provides habitat for native flora and fauna; as well as providing ecosystem services such as flood mitigation and nutrient cycling. Understanding the dynamic nature of this system, and its main controls, is important in relation to the future conservation and management of the wetland and associated water resources.

There is a dynamic link between wetland hydrology and the inputs from both surface and ground water resources. Shallow groundwater abstraction near the Te Harakiki wetland at Waikanae has the potential to impact on the wetland's hydrosystem. To assess the potential for this: a detailed analysis of temporal and spatial changes; an assessment of the hydrological regime; and, calculation of the water balance for the Te Harakiki Wetland system were needed.

Historical aerial photograph analysis showed that the area covered by the wetland had decreased dramatically since 1966. The settlement of Waikanae Beach bordering the wetland has increased. To understand how different hydrological systems and processes within the wetland inter-relate various field methods were implemented. Field data were compared to historical rainfall and evapotranspiration records for the area. This enabled an assessment of the possible causal factors for the temporal changes in wetland extent seen in the historical aerial photographs.

Hydrometric time series analysis was carried out on rainfall, soil moisture, and surface and groundwater data collected from seven sites around Te Harakiki. The interrelationships and dynamics of these processes, and how they influence the hydrology of the wetland, were investigated. The surface and shallow groundwater systems are closely linked. Both show similar response patterns to rainfall events. The lag time and slight difference in height between the peaks in surface water and 
groundwater can be attributed to the buffering effects of percolation of water through the soil profile. Soil moisture records showed that the water table near the wetland was at approximately one metre.

A water balance for Te Harakiki shows strong climatic control on wetland hydrology. The stream channel underwent extensive modification to provide flood protection for the nearby residential area during the $20^{\text {th }}$ century. It is likely that surface water inflows previously contributed more to the wetland system than at present.

Water restrictions by KCDC have led to many properties having shallow groundwater bores for garden irrigation. The exact number of bores and total volume of abstraction are unknown. Until 2000 a resource consent was not required for the construction of these types of bores. Using estimates of bore numbers and abstraction rates Jones and Gyopari (2005) showed that groundwater abstraction from these bores had little effect on water levels within the wetland. However, groundwater levels in the region appear to be decreasing. As groundwater supplies $65 \%$ of water inflows, a prolonged reduction in the level of groundwater will have a detrimental effect on the wetland system.

The fragmentation and drainage of surrounding wetland areas is most likely the largest contributing factor to the historical reduction of wetland habitat seen at $\mathrm{Te}$ Harakiki. Since the early 1990's measures have been put in place to restore the wetland, and halt its decline. These measures appear to have had some positive effect as the wetland recovered between 1996 and 2002.

The water balance for Te Harakiki was positive, meaning that there is a daily increase in water storage within the system, during the period of this study. Approximately $91 \%$ of total water inflows are lost from the system as outflows. This indicates that the wetland is getting wetter (growing), and with the current restoration efforts the future for this unique ecosystem looks positive. Sustainable management of the shallow groundwater resource is essential to ensure this. 


\subsection{Recommendations}

A semi-quantitative water balance was constructed for the Te Harakiki wetland. From this, the main controls on the hydrology of the system were identified. The accuracy and applicability of this water balance could be enhanced by further work in the area. Conservation efforts within the area could also benefit from the following recommendations:

- Gathering detailed hydrometric data from the area over a longer time period. This would allow an assessment of long term trends in the wetland, as opposed to seasonal variations.

- Isotope $\left(\mathrm{O}_{18}\right)$ analysis of the groundwater in the monitoring bores, together with water from the stream and wetland, may indicate groundwater flow paths, its residence time and define the 'source' of the groundwater.

- Further surface and groundwater quality testing within the wetland catchment would add to existing data and provide baseline information. Long term trends in water quality within the catchment could then be assessed.

- The exact effects of tides on the hydrology of the lower reaches of the Ngarara Stream need to be quantified. Therefore, a more accurate stage/discharge relationship for the stream needs to be constructed. The volume of surface water inflow to the wetland could then be adjusted accordingly. Conductivity testing at various points along the stream may help to determine the extent of the tidal influence in the stream.

- A detailed assessment of the residential area bordering the wetland, to determine the number of bores and volume of shallow groundwater use in the vicinity of Te Harakiki, is essential. This could involve door-to-door inquiries to determine the locations of the bores. Metering of a representative number of bores would help to estimate abstraction levels. 
- Resistivity surveys have located the saline interface in the shallow gravel aquifer near the Waikanae River mouth. Similar surveys could be extended further up the coast to determine the location of the interface near Te Harakiki. This may have implications for groundwater management and use in this area; particularly if there is to be increased abstraction from groundwater. 


\section{Appendix 1}

\section{Evapotranspiration values tables}

Table 1 (a)

Atmospheric pressure (P) for different altitudes ( $\mathrm{z}$ )

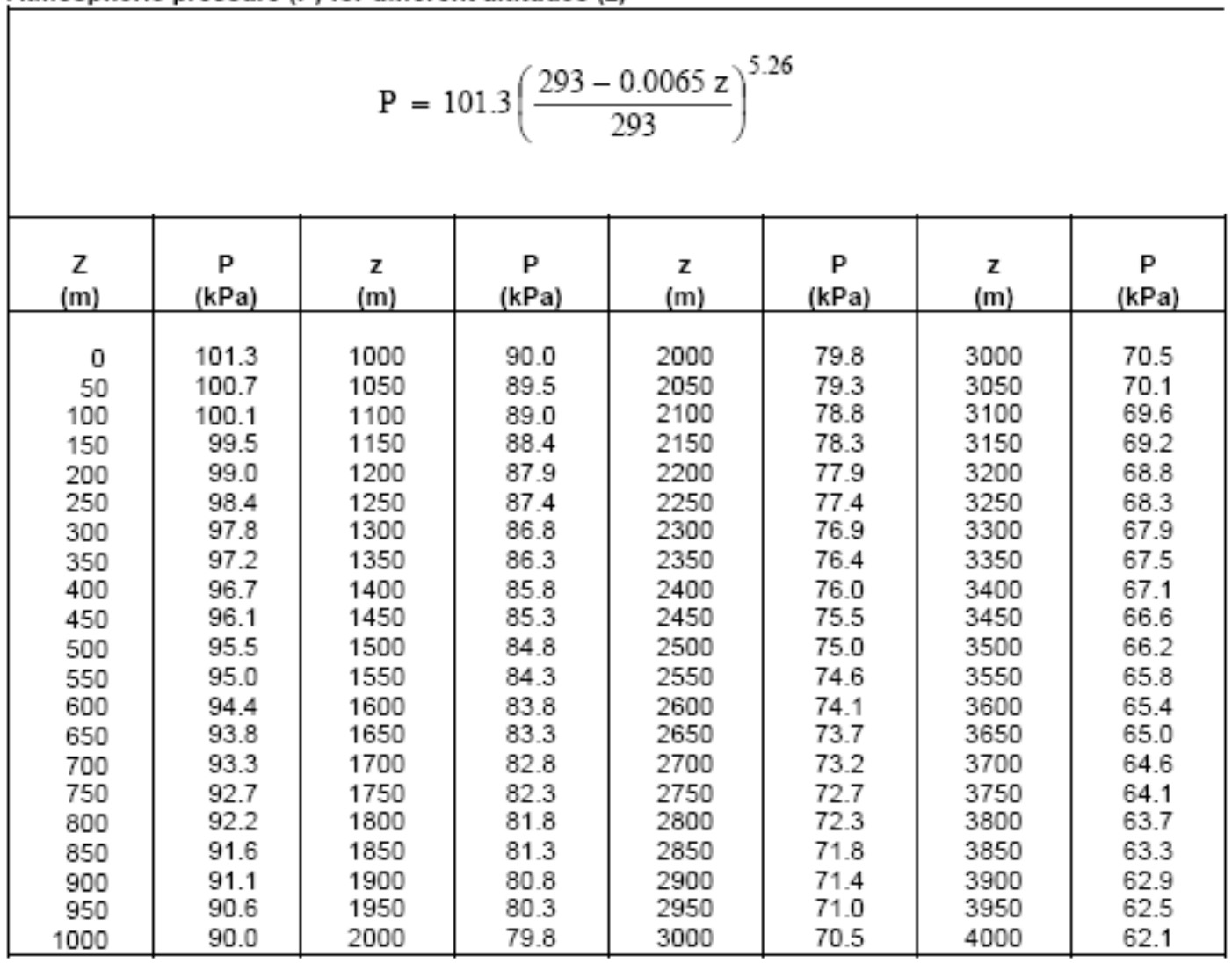

Table 1(b)

Psychrometric constant $(y)$ for different altitudes $(z)$

\begin{tabular}{|c|c|c|c|c|c|c|c|}
\hline \multicolumn{8}{|c|}{$\gamma=\frac{\mathrm{c}_{\mathrm{p}} \mathrm{P}}{\varepsilon \lambda}=0.665 \times 10^{-3} \mathrm{P}$} \\
\hline$\underset{(m)}{Z}$ & $\begin{array}{c}\gamma \\
\mathrm{kPa} /{ }^{\circ} \mathrm{C} \\
\end{array}$ & $\begin{array}{c}\mathbf{z} \\
(\mathrm{m})\end{array}$ & $\begin{array}{c}\gamma \\
\mathrm{kPa} /{ }^{\circ} \mathrm{C}\end{array}$ & $\begin{array}{c}\mathbf{z} \\
(\mathrm{m})\end{array}$ & $\begin{array}{c}\boldsymbol{\gamma} \\
\mathrm{kPa} /{ }^{\circ} \mathrm{C}\end{array}$ & $\begin{array}{c}\mathbf{Z} \\
(\mathrm{m})\end{array}$ & $\begin{array}{c}\boldsymbol{\gamma} \\
\mathrm{kPa} /{ }^{\circ} \mathrm{C}\end{array}$ \\
\hline 0 & 0.067 & 1000 & 0.060 & 2000 & 0.053 & 3000 & 0.047 \\
\hline 100 & 0.067 & 1100 & 0.059 & 2100 & 0.052 & 3100 & 0.046 \\
\hline 200 & 0.066 & 1200 & 0.058 & 2200 & 0.052 & 3200 & 0.046 \\
\hline 300 & 0.065 & 1300 & 0.058 & 2300 & 0.051 & 3300 & 0.045 \\
\hline 400 & 0.064 & 1400 & 0.057 & 2400 & 0.051 & 3400 & 0.045 \\
\hline 500 & 0.064 & 1500 & 0.056 & 2500 & 0.050 & 3500 & 0.044 \\
\hline 600 & 0.063 & 1600 & 0.056 & 2600 & 0.049 & 3600 & 0.043 \\
\hline 700 & 0.062 & 1700 & 0.055 & 2700 & 0.049 & 3700 & 0.043 \\
\hline 800 & 0.061 & 1800 & 0.054 & 2800 & 0.048 & 3800 & 0.042 \\
\hline 900 & 0.061 & 1900 & 0.054 & 2900 & 0.047 & 3900 & 0.042 \\
\hline 1000 & 0.060 & 2000 & 0.053 & 3000 & 0.047 & 4000 & 0.041 \\
\hline
\end{tabular}

Based on $\lambda=2.45 \mathrm{MJ} \mathrm{kg}^{-1}$ at $20^{\circ} \mathrm{C}$. 
Table 1 (c)

Saturation vapour pressure $\left(e^{\circ}(T)\right)$ for different temperatures $(T)$

$$
e^{\circ}(T)=0.6108 \exp \left[\frac{17.27 T}{T+237.3}\right]
$$

\begin{tabular}{|c|c|c|c|c|c|c|c|}
\hline $\begin{array}{c}\mathrm{T} \\
{ }^{\circ} \mathrm{C}\end{array}$ & $\underset{k P_{a}}{e_{s}}$ & $\begin{array}{c}\mathrm{T} \\
{ }^{\circ} \mathrm{C}\end{array}$ & $\begin{array}{c}\mathrm{e}^{\circ}(\mathrm{T}) \\
\mathrm{kPa}\end{array}$ & $\begin{array}{c}\mathrm{T} \\
{ }^{\circ} \mathrm{C}\end{array}$ & $\begin{array}{l}\mathrm{e}^{\circ}(\mathrm{T}) \\
\mathrm{kPa}\end{array}$ & $\begin{array}{c}\mathrm{T} \\
{ }^{\circ} \mathrm{C}\end{array}$ & $\begin{array}{c}\mathrm{e}_{\mathrm{S}} \\
\mathrm{kPa}\end{array}$ \\
\hline 1.0 & 0.657 & 13.0 & 1.498 & 25.0 & 3.168 & 37.0 & 6.275 \\
\hline 1.5 & 0.681 & 13.5 & 1.547 & 25.5 & 3.263 & 37.5 & 6.448 \\
\hline 2.0 & 0.706 & 14.0 & 1.599 & 26.0 & 3.361 & 38.0 & 6.625 \\
\hline 2.5 & 0.731 & 14.5 & 1.651 & 26.5 & 3.462 & 38.5 & 6.806 \\
\hline 3.0 & 0.758 & 15.0 & 1.705 & 27.0 & 3.565 & 39.0 & 6.991 \\
\hline 3.5 & 0.785 & 15.5 & 1.761 & 27.5 & 3.671 & 39.5 & 7.181 \\
\hline 4.0 & 0.813 & 16.0 & 1.818 & 28.0 & 3.780 & 40.0 & 7.376 \\
\hline 4.5 & 0.842 & 16.5 & 1.877 & 28.5 & 3.891 & 40.5 & 7.574 \\
\hline 5.0 & 0.872 & 17.0 & 1.938 & 29.0 & 4.006 & 41.0 & 7.778 \\
\hline 5.5 & 0.903 & 17.5 & 2.000 & 29.5 & 4.123 & 41.5 & 7.986 \\
\hline 6.0 & 0.935 & 18.0 & 2.064 & 30.0 & 4.243 & 42.0 & 8.199 \\
\hline 6.5 & 0.968 & 18.5 & 2.130 & 30.5 & 4.366 & 42.5 & 8.417 \\
\hline 7.0 & 1.002 & 19.0 & 2.197 & 31.0 & 4.493 & 43.0 & 8.640 \\
\hline 7.5 & 1.037 & 19.5 & 2.267 & 31.5 & 4.622 & 43.5 & 8.867 \\
\hline 8.0 & 1.073 & 20.0 & 2.338 & 32.0 & 4.755 & 44.0 & 9.101 \\
\hline 8.5 & 1.110 & 20.5 & 2.412 & 32.5 & 4.891 & 44.5 & 9.339 \\
\hline 9.0 & 1.148 & 21.0 & 2.487 & 33.0 & 5.030 & 45.0 & 9.582 \\
\hline 9.5 & 1.187 & 21.5 & 2.564 & 33.5 & 5.173 & 45.5 & 9.832 \\
\hline 10.0 & 1.228 & 22.0 & 2.644 & 34.0 & 5.319 & 46.0 & 10.086 \\
\hline 10.5 & 1.270 & 22.5 & 2.726 & 34.5 & 5.469 & 46.5 & 10.347 \\
\hline 11.0 & 1.313 & 23.0 & 2.809 & 35.0 & 5.623 & 47.0 & 10.613 \\
\hline 11.5 & 1.357 & 23.5 & 2.896 & 35.5 & 5.780 & 47.5 & 10.885 \\
\hline 12.0 & 1.403 & 24.0 & 2.984 & 36.0 & 5.941 & 48.0 & 11.163 \\
\hline 12.5 & 1.449 & 24.5 & 3.075 & 36.5 & 6.106 & 48.5 & 11.447 \\
\hline
\end{tabular}


Table 1 (d)

Saturation vapour pressure $\left(\mathrm{e}^{\circ}(\mathrm{T})\right)$ for different temperatures $(\mathrm{T})$

$$
e^{0}(T)=0.6108 \exp \left[\frac{17.27 T}{T+237.3}\right]
$$

\begin{tabular}{|r|c|c|c|c|c|c|c|}
\hline $\begin{array}{c}\mathbf{T} \\
{ }^{\circ} \mathbf{C}\end{array}$ & $\begin{array}{c}\mathbf{e}_{\mathbf{S}} \\
\mathbf{k P a}\end{array}$ & $\begin{array}{c}\mathrm{T} \\
{ }^{\circ} \mathbf{C}\end{array}$ & $\begin{array}{c}\mathbf{e}^{\circ} \mathbf{( T )} \\
\mathbf{k P a}\end{array}$ & $\begin{array}{c}\mathbf{T} \\
{ }^{\circ} \mathbf{C}\end{array}$ & $\begin{array}{c}\mathbf{e}^{\circ}(\mathrm{T}) \\
\mathbf{k P a}\end{array}$ & $\begin{array}{c}\mathrm{T} \\
{ }^{\circ} \mathrm{C}\end{array}$ & $\begin{array}{c}\mathbf{e}_{\mathbf{S}} \\
\mathbf{k P a}\end{array}$ \\
\hline 1.0 & 0.657 & 13.0 & 1.498 & 25.0 & 3.168 & 37.0 & 6.275 \\
1.5 & 0.681 & 13.5 & 1.547 & 25.5 & 3.263 & 37.5 & 6.448 \\
2.0 & 0.706 & 14.0 & 1.599 & 26.0 & 3.361 & 38.0 & 6.625 \\
2.5 & 0.731 & 14.5 & 1.651 & 26.5 & 3.462 & 38.5 & 6.806 \\
3.0 & 0.758 & 15.0 & 1.705 & 27.0 & 3.565 & 39.0 & 6.991 \\
3.5 & 0.785 & 15.5 & 1.761 & 27.5 & 3.671 & 39.5 & 7.181 \\
4.0 & 0.813 & 16.0 & 1.818 & 28.0 & 3.780 & 40.0 & 7.376 \\
4.5 & 0.842 & 16.5 & 1.877 & 28.5 & 3.891 & 40.5 & 7.574 \\
5.0 & 0.872 & 17.0 & 1.938 & 29.0 & 4.006 & 41.0 & 7.778 \\
5.5 & 0.903 & 17.5 & 2.000 & 29.5 & 4.123 & 41.5 & 7.986 \\
6.0 & 0.935 & 18.0 & 2.064 & 30.0 & 4.243 & 42.0 & 8.199 \\
6.5 & 0.968 & 18.5 & 2.130 & 30.5 & 4.366 & 42.5 & 8.417 \\
7.0 & 1.002 & 19.0 & 2.197 & 31.0 & 4.493 & 43.0 & 8.640 \\
7.5 & 1.037 & 19.5 & 2.267 & 31.5 & 4.622 & 43.5 & 8.867 \\
8.0 & 1.073 & 20.0 & 2.338 & 32.0 & 4.755 & 44.0 & 9.101 \\
8.5 & 1.110 & 20.5 & 2.412 & 32.5 & 4.891 & 44.5 & 9.339 \\
9.0 & 1.148 & 21.0 & 2.487 & 33.0 & 5.030 & 45.0 & 9.582 \\
9.5 & 1.187 & 21.5 & 2.564 & 33.5 & 5.173 & 45.5 & 9.832 \\
10.0 & 1.228 & 22.0 & 2.644 & 34.0 & 5.319 & 46.0 & 10.086 \\
10.5 & 1.270 & 22.5 & 2.726 & 34.5 & 5.469 & 46.5 & 10.347 \\
11.0 & 1.313 & 23.0 & 2.809 & 35.0 & 5.623 & 47.0 & 10.613 \\
11.5 & 1.357 & 23.5 & 2.896 & 35.5 & 5.780 & 47.5 & 10.885 \\
12.0 & 1.403 & 24.0 & 2.984 & 36.0 & 5.941 & 48.0 & 11.163 \\
12.5 & 1.449 & 24.5 & 3.075 & 36.5 & 6.106 & 48.5 & 11.447 \\
\hline
\end{tabular}


Table 1 (e)

Slope of vapour pressure curve $(\boldsymbol{\Delta})$ for different temperatures (T)

$$
\Delta=\frac{4098\left[0.6108 \exp \left(\frac{17.27 \mathrm{~T}}{\mathrm{~T}+237.3}\right)\right]}{(\mathrm{T}+237.3)^{2}}
$$

\begin{tabular}{|c|c|c|c|c|c|c|c|}
\hline $\begin{array}{l}\mathrm{T} \\
{ }^{\circ} \mathrm{C}\end{array}$ & $\underset{\mathrm{kPa}^{\circ}{ }^{\circ} \mathrm{C}}{\boldsymbol{\Delta}}$ & $\begin{array}{l}\mathrm{T} \\
{ }^{\circ} \mathrm{C}\end{array}$ & $\begin{array}{c}\Delta \\
\mathrm{kPa} /{ }^{\circ} \mathrm{C}\end{array}$ & $\begin{array}{l}\mathrm{T} \\
{ }^{\circ} \mathrm{C}\end{array}$ & $\begin{array}{c}\Delta \\
\mathrm{kPa} /{ }^{\circ} \mathrm{C}\end{array}$ & $\begin{array}{l}\mathrm{T} \\
{ }^{\circ} \mathrm{C}\end{array}$ & $\underset{\mathrm{kPa} /{ }^{\circ} \mathrm{C}}{\Delta}$ \\
\hline 1.0 & 0.047 & 13.0 & 0.098 & 25.0 & 0.189 & 37.0 & 0.342 \\
\hline 1.5 & 0.049 & 13.5 & 0.101 & 25.5 & 0.194 & 37.5 & 0.350 \\
\hline 2.0 & 0.050 & 14.0 & 0.104 & 26.0 & 0.199 & 38.0 & 0.358 \\
\hline 2.5 & 0.052 & 14.5 & 0.107 & 26.5 & 0.204 & 38.5 & 0.367 \\
\hline 3.0 & 0.054 & 15.0 & 0.110 & 27.0 & 0.209 & 39.0 & 0.375 \\
\hline 3.5 & 0.055 & 15.5 & 0.113 & 27.5 & 0.215 & 39.5 & 0.384 \\
\hline 4.0 & 0.057 & 16.0 & 0.116 & 28.0 & 0.220 & 40.0 & 0.393 \\
\hline 4.5 & 0.059 & 16.5 & 0.119 & 28.5 & 0.226 & 40.5 & 0.402 \\
\hline 5.0 & 0.061 & 17.0 & 0.123 & 29.0 & 0.231 & 41.0 & 0.412 \\
\hline 5.5 & 0.063 & 17.5 & 0.126 & 29.5 & 0.237 & 41.5 & 0.421 \\
\hline 6.0 & 0.065 & 18.0 & 0.130 & 30.0 & 0.243 & 42.0 & 0.431 \\
\hline 6.5 & 0.067 & 18.5 & 0.133 & 30.5 & 0.249 & 42.5 & 0.441 \\
\hline 7.0 & 0.069 & 19.0 & 0.137 & 31.0 & 0.256 & 43.0 & 0.451 \\
\hline 7.5 & 0.071 & 19.5 & 0.141 & 31.5 & 0.262 & 43.5 & 0.461 \\
\hline 8.0 & 0.073 & 20.0 & 0.145 & 32.0 & 0.269 & 44.0 & 0.471 \\
\hline 8.5 & 0.075 & 20.5 & 0.149 & 32.5 & 0.275 & 44.5 & 0.482 \\
\hline 9.0 & 0.078 & 21.0 & 0.153 & 33.0 & 0.282 & 45.0 & 0.493 \\
\hline 9.5 & 0.080 & 21.5 & 0.157 & 33.5 & 0.289 & 45.5 & 0.504 \\
\hline 10.0 & 0.082 & 22.0 & 0.161 & 34.0 & 0.296 & 46.0 & 0.515 \\
\hline 10.5 & 0.085 & 22.5 & 0.165 & 34.5 & 0.303 & 46.5 & 0.526 \\
\hline 11.0 & 0.087 & 23.0 & 0.170 & 35.0 & 0.311 & 47.0 & 0.538 \\
\hline 11.5 & 0.090 & 23.5 & 0.174 & 35.5 & 0.318 & 47.5 & 0.550 \\
\hline 12.0 & 0.092 & 24.0 & 0.179 & 36.0 & 0.326 & 48.0 & 0.562 \\
\hline 12.5 & 0.095 & 24.5 & 0.184 & 36.5 & 0.334 & 48.5 & 0.574 \\
\hline
\end{tabular}


Table 1 (f)

Number of the day in the year $(\mathrm{J})$

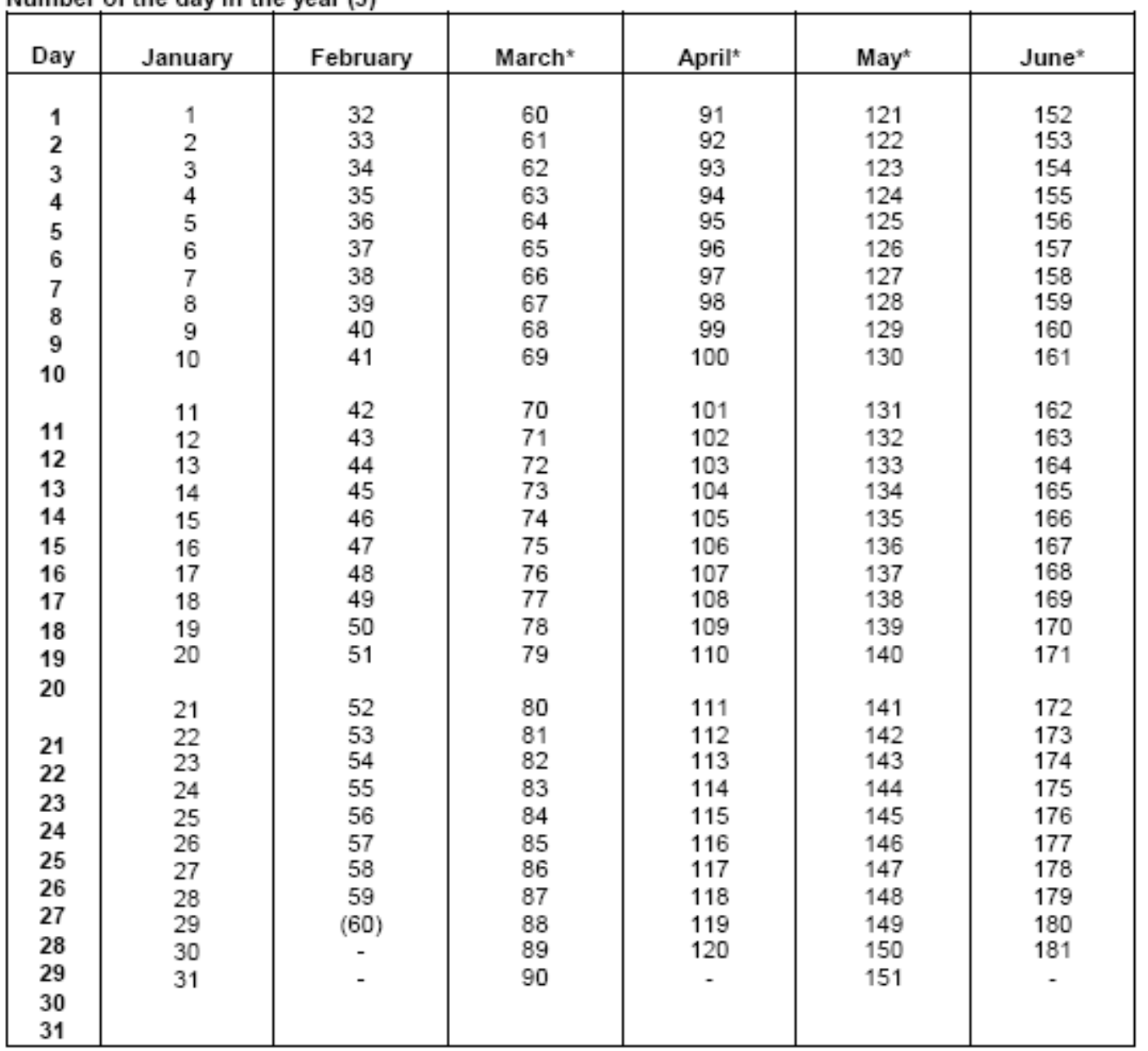

TABAE 2. add 1 if leap year

$J$ can be determined for each day (D) of month (M) by

$J=$ INTEGER(275 M/9 - 30 + D ) - 2

IF $(\mathrm{M}<3) \quad$ THEN $\mathrm{J}=\mathrm{J}+2$

also,

IF (leap year and $(M>2)$ ) THEN $\mathrm{J}=\mathrm{J}+1$

For ten-day calculations, compute $\mathrm{J}$ for day $\mathrm{D}=5,15$ and 25

For monthly calculations, $\mathrm{J}$ at the middle of the month is approximately given by $J=\operatorname{INTEGER}(30.4 \mathrm{M}-15)$ 
Table 1 (f) (continued)

Number of the day in the year $(\mathrm{J})$

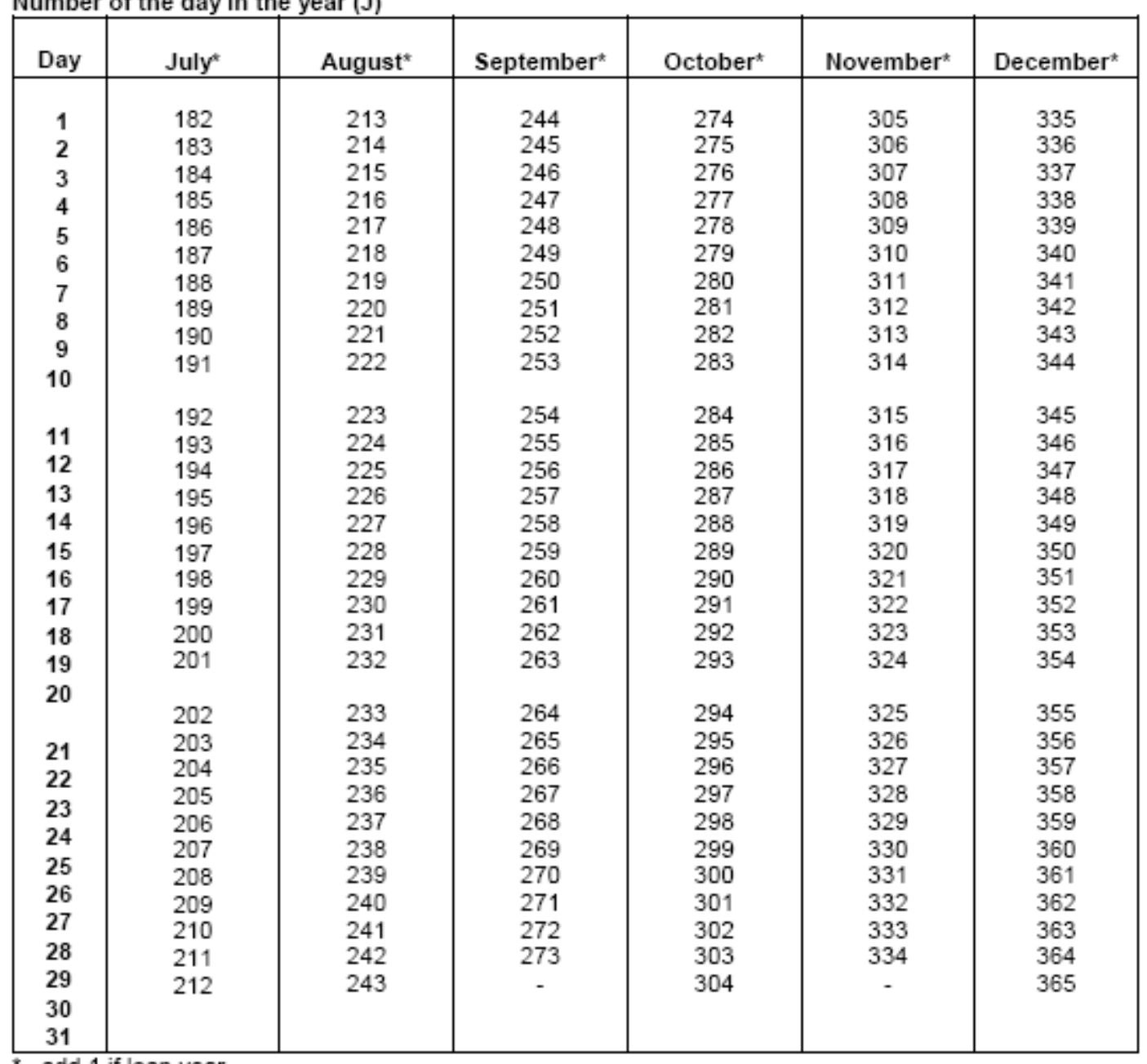

add 1 if leap year 
Table 1 (g)

$\sigma_{\mathbf{K}}{ }^{4}$ (Stefan-Boltzmann law) at different temperatures (T)

\begin{tabular}{|c|c|c|c|c|c|}
\hline $\begin{array}{c}\mathrm{T} \\
\left({ }^{\circ} \mathrm{C}\right) \\
\end{array}$ & $\begin{array}{c}\sigma \mathrm{T}_{\mathrm{K}^{4}}^{4} \\
\left(\mathrm{MJ} \mathrm{m}^{-2} \mathrm{~d}^{-1}\right)\end{array}$ & $\begin{array}{c}\mathrm{T} \\
\left({ }^{\circ} \mathrm{C}\right) \\
\end{array}$ & $\begin{array}{c}\sigma \mathrm{T}_{\mathrm{K}^{4}}^{4} \\
\left(\mathrm{MJ} \mathrm{m}^{-2} \mathrm{~d}^{-1}\right)\end{array}$ & $\begin{array}{c}\mathrm{T} \\
\left({ }^{\circ} \mathrm{C}\right) \\
\end{array}$ & $\begin{array}{c}\sigma \mathrm{T} \mathrm{K}^{4} \\
\left(\mathrm{MJ} \mathrm{m}^{-2} \mathrm{~d}^{-1}\right)\end{array}$ \\
\hline 1.0 & 27.70 & 17.0 & 34.75 & 33.0 & 43.08 \\
\hline 1.5 & 27.90 & 17.5 & 34.99 & 33.5 & 43.36 \\
\hline 2.0 & 28.11 & 18.0 & 35.24 & 34.0 & 43.64 \\
\hline 2.5 & 28.31 & 18.5 & 35.48 & 34.5 & 43.93 \\
\hline 3.0 & 28.52 & 19.0 & 35.72 & 35.0 & 44.21 \\
\hline 3.5 & 28.72 & 19.5 & 35.97 & 35.5 & 44.50 \\
\hline 4.0 & 28.93 & 20.0 & 36.21 & 36.0 & 44.79 \\
\hline 4.5 & 29.14 & 20.5 & 36.46 & 36.5 & 45.08 \\
\hline 5.0 & 29.35 & 21.0 & 36.71 & 37.0 & 45.37 \\
\hline 5.5 & 29.56 & 21.5 & 36.96 & 37.5 & 45.67 \\
\hline 6.0 & 29.78 & 22.0 & 37.21 & 38.0 & 45.96 \\
\hline 6.5 & 29.99 & 22.5 & 37.47 & 38.5 & 46.26 \\
\hline 7.0 & 30.21 & 23.0 & 37.72 & 39.0 & 46.56 \\
\hline 7.5 & 30.42 & 23.5 & 37.98 & 39.5 & 46.85 \\
\hline 8.0 & 30.64 & 24.0 & 38.23 & 40.0 & 47.15 \\
\hline 8.5 & 30.86 & 24.5 & 38.49 & 40.5 & 47.46 \\
\hline 9.0 & 31.08 & 25.0 & 38.75 & 41.0 & 47.76 \\
\hline 9.5 & 31.30 & 25.5 & 39.01 & 41.5 & 48.06 \\
\hline 10.0 & 31.52 & 26.0 & 39.27 & 42.0 & 48.37 \\
\hline 10.5 & 31.74 & 26.5 & 39.53 & 42.5 & 48.68 \\
\hline 11.0 & 31.97 & 27.0 & 39.80 & 43.0 & 48.99 \\
\hline 11.5 & 32.19 & 27.5 & 40.06 & 43.5 & 49.30 \\
\hline 12.0 & 32.42 & 28.0 & 40.33 & 44.0 & 49.61 \\
\hline 12.5 & 32.65 & 28.5 & 40.60 & 44.5 & 49.92 \\
\hline 13.0 & 32.88 & 29.0 & 40.87 & 45.0 & 50.24 \\
\hline 13.5 & 33.11 & 29.5 & 41.14 & 45.5 & 50.56 \\
\hline 14.0 & 33.34 & 30.0 & 41.41 & 46.0 & 50.87 \\
\hline 14.5 & 33.57 & 30.5 & 41.69 & 46.5 & 51.19 \\
\hline 15.0 & 33.81 & 31.0 & 41.96 & 47.0 & 51.51 \\
\hline 15.5 & 34.04 & 31.5 & 42.24 & 47.5 & 51.84 \\
\hline 16.0 & 34.28 & 32.0 & 42.52 & 48.0 & 52.16 \\
\hline 16.5 & 34.52 & 32.5 & 42.80 & 48.5 & 52.49 \\
\hline
\end{tabular}




\section{Appendix 2}

\section{Tidal data}

Secondary Ports Table for PORT TARANAKI

Data sourced from NZ Nautical Almanac 2007/08

\begin{tabular}{|c|c|c|c|c|c|c|c|c|c|c|}
\hline \multirow[b]{2}{*}{ Port } & \multirow{2}{*}{\multicolumn{2}{|c|}{ Lat. S. }} & \multirow{2}{*}{ Long. E. } & \multicolumn{2}{|c|}{ Mean Time Differences } & \multicolumn{5}{|c|}{ Mean Spring, Neap and Sea Level Heights (metres) } \\
\hline & & & & HW & LW & MHWS & MHWN & MLWN & MLWS & MSL \\
\hline PORT TARANAKI & 39 & 04 & 17402 & hhmm & hhmm & 3.5 & 2.7 & 1.2 & 0.4 & 1.96 \\
\hline Ahipara Bay & 35 & 10 & 17307 & -0015 & -0015 & 3.6 & 2.9 & 1.1 & 0.4 & $2.0^{*}$ \\
\hline Aotea Harbour & 38 & 00 & 17450 & -0004 & -0004 & 3.7 & 2.9 & 1.2 & 0.4 & $2.1^{*}$ \\
\hline Cape Maria van Diemen & 34 & 29 & 17238 & -0035 & -0035 & 2.4 & 2.1 & 0.6 & 0.3 & $1.4^{*}$ \\
\hline Karehana Bay (Plimmerton Boating Club) & 41 & 04 & 17451 & -0013 & -0022 & 1.5 & 0.9 & 0.8 & 0.2 & 0.8 * \\
\hline Kawhia & 38 & 04 & 17449 & +0018 & +0018 & 3.5 & 2.8 & 1.2 & 0.5 & 2.0 \\
\hline Makara Beach & 41 & 13 & 17442 & -0040 & -0040 & 1.3 & 0.9 & 0.7 & 0.3 & $0.8^{*}$ \\
\hline Manawatu River Entrance & 40 & 28 & 17513 & -0020 & +0020 & 2.4 & 1.8 & 0.9 & 0.2 & $1.3^{*}$ \\
\hline Otaki River Entrance & 40 & 45 & 17506 & -0020 & -0020 & - & - & - & - & - * \\
\hline Paraparaumu Beach & 40 & 54 & 17459 & -0020 & -0020 & - & - & - & - & - * \\
\hline Porirua Harbour (Mana Cruising Club) & 41 & 06 & 17452 & +0023 & +0020 & 1.4 & 1.0 & 0.6 & 0.2 & $0.8 *$ \\
\hline Raglan & 37 & 48 & 17453 & +0023 & +0008 & 3.2 & 2.5 & 0.9 & 0.1 & 1.8 \\
\hline Waikanae River Entrance & 40 & 52 & 17500 & +0008 & +0004 & - & - & - & - & - * \\
\hline Waikato River Entrance & 37 & 24 & 17445 & -0004 & -0004 & 3.7 & 3.0 & 1.2 & 0.5 & $2.1 *$ \\
\hline Waitarere Beach & 40 & 34 & 17511 & -0020 & -0020 & - & - & - & - & $-*$ \\
\hline \multicolumn{11}{|l|}{ Hokianga Harbour } \\
\hline Kohukohu & 35 & 22 & 17332 & +0015 & +0015 & 3.3 & 2.8 & 0.8 & 0.3 & $1.8^{*}$ \\
\hline Opononi & 35 & 30 & 17324 & +0005 & +0002 & 2.9 & 2.3 & 0.7 & 0.1 & 1.5 \\
\hline Rawene & 35 & 24 & 17330 & +0026 & +0016 & 3.3 & 2.7 & 1.0 & 0.4 & 1.9 \\
\hline \multicolumn{11}{|l|}{ Kaipara Harbour } \\
\hline Dargaville & 35 & 56 & 17352 & +0228 & +0346 & - & - & - & - & - \\
\hline Helensville & 36 & 40 & 17427 & +0222 & +0249 & - & - & - & - & $-*$ \\
\hline Island Point & 36 & 14 & 17405 & +0046 & +0046 & 3.6 & 2.8 & 1.1 & 0.3 & 1.9 \\
\hline Pouto Point & 36 & 22 & 17411 & +0039 & +0035 & 3.2 & 2.7 & 0.8 & 0.4 & 1.8 \\
\hline Shelly Beach & 36 & 34 & 17423 & +0155 & +0200 & 4.2 & 3.4 & 1.5 & 0.7 & 2.4 \\
\hline Te Kopuru & 36 & 02 & 17356 & +0156 & +0236 & 3.4 & 3.0 & - & - & $-*$ \\
\hline Tikinui & 36 & 07 & 17358 & +0144 & +0210 & 3.6 & 3.0 & 1.0 & 0.3 & 2.0 \\
\hline Tinopai & 36 & 15 & 17415 & +0058 & +0059 & 3.6 & 2.8 & 1.1 & 0.3 & 2.0 \\
\hline Whakapirau & 36 & 09 & 17415 & +0125 & +0107 & 3.9 & 3.0 & 1.2 & 0.3 & 2.1 \\
\hline \multicolumn{11}{|l|}{ Kapiti Island } \\
\hline Waiorua Bay & 40 & 50 & 17457 & -0017 & -0017 & 1.7 & 1.2 & 0.9 & 0.4 & $1.1^{*}$ \\
\hline \multicolumn{11}{|l|}{ Manawatahi/Three Kings Islands } \\
\hline Great Island (North West Bay) & 34 & 09 & 17209 & -0136 & -0133 & 2.4 & 2.0 & 0.7 & 0.4 & 1.4 \\
\hline \multicolumn{11}{|l|}{ North Taranaki Bight } \\
\hline Waitara River Entrance & 38 & 59 & 17414 & 0000 & 0000 & 3.5 & 2.9 & 1.1 & 0.4 & $2.0^{*}$ \\
\hline \multicolumn{11}{|l|}{ South Taranaki Bight } \\
\hline Opunake Bay & 39 & 28 & 17351 & -0005 & -0005 & 3.3 & 2.7 & 1.0 & 0.3 & $1.8^{*}$ \\
\hline Patea & 39 & 47 & 17429 & -0010 & -0010 & 2.5 & 1.9 & 0.8 & 0.2 & $1.3^{*}$ \\
\hline Whanganui River Entrance & 39 & 57 & 17459 & +0035 & +0035 & 2.8 & 2.2 & 1.3 & 0.7 & $1.7^{*}$ \\
\hline
\end{tabular}

* Data Approximate - No Data 


\section{Appendix 3}

Monthly water balance values.

\begin{tabular}{|c|c|c|}
\hline \multicolumn{1}{|c}{ August - Water Balance } \\
\hline Precipitation & In $\left(\mathrm{m}^{3} /\right.$ day $)$ & Out ( $\mathrm{m}^{3} /$ day $)$ \\
\hline Evapotranspiration & -- & -- \\
\hline Surface water & 1,210 & 960 \\
\hline Groundwater & 1,404 & 820 \\
\hline Total & 3,294 & 181 \\
\hline TOTAL (in - out) & 1,333 & 1961 \\
\hline
\end{tabular}

The mean monthly precipitation rate for August from site 7 is $2.2 \mathrm{~mm} / \mathrm{day}$. This equates to a daily average input of $660 \mathrm{~m}^{3} /$ day assuming a wetland area of $30 \mathrm{ha}$.

The mean monthly reference evapotranspiration rate for August calculated using the FAO Penman-Monteith equation is $3.2 \mathrm{~mm} /$ day. This equates to $1,035 \mathrm{~m}^{3} / \mathrm{day}$ assuming a wetland area of $30 \mathrm{ha}$.

\begin{tabular}{|c|c|c|}
\hline \multicolumn{3}{|c|}{ September - water balance } \\
\hline Precipitation & In ( $\mathrm{m}^{3} /$ day $)$ & Out ( $\mathrm{m}^{3} /$ day $)$ \\
\hline Evapotranspiration & -- & -- \\
\hline Surface water & 2,160 & 1,230 \\
\hline Groundwater & 1,404 & 1,620 \\
\hline Total & 4,166 & 181 \\
\hline TOTAL (in - out) & 1,135 & 3,031 \\
\hline
\end{tabular}

The mean monthly precipitation rate for September from site 7 is $2 \mathrm{~mm} / \mathrm{day}$. This equates to a daily average input of $602 \mathrm{~m}^{3} /$ day assuming a wetland area of $30 \mathrm{ha}$.

The mean monthly reference evapotranspiration rate for September calculated using the FAO Penman-Monteith equation is $4.1 \mathrm{~mm} /$ day. This equates to $1,230 \mathrm{~m}^{3} /$ day assuming a wetland area of $30 \mathrm{ha}$. 


\begin{tabular}{|c|c|c|}
\hline \multicolumn{1}{|c|}{ October - water balance } \\
\hline Precipitation & 1,228 & Out $\left(\mathrm{m}^{3} / \mathrm{day}\right)$ \\
\hline Evapotranspiration & -- & -- \\
\hline Surface water & $-1,296^{*}$ & 1,020 \\
\hline Groundwater & 1,287 & $-620^{* *}$ \\
\hline Total & 1,219 & 166 \\
\hline TOTAL (in - out) & 653 & 566 \\
\hline
\end{tabular}

**There was no loss from the wetland to the stream, due to high flow levels in the stream it added an extra $620 \mathrm{~m}^{3} /$ day to the wetland

The mean monthly precipitation rate for October from site 7 is $4 \mathrm{~mm} /$ day. This equates to a daily average input of 1,228 /day assuming a wetland area of $30 \mathrm{ha}$.

The mean monthly reference evapotranspiration rate for October calculated using the FAO Penman-Monteith equation is $3.4 \mathrm{~mm} /$ day. This equates to $1,020 \mathrm{~m}^{3} / \mathrm{day}$ assuming a wetland area of $30 \mathrm{ha}$.

November - water balance

\begin{tabular}{|c|c|c|}
\hline & $\operatorname{In}\left(\mathrm{m}^{3} /\right.$ day $)$ & Out $\left(\mathrm{m}^{3} /\right.$ day $)$ \\
\hline Precipitation & 411 & -- \\
\hline Evapotranspiration & -- & 1,110 \\
\hline Surface water & 173 & 420 \\
\hline Groundwater & 1,326 & 171 \\
\hline Total & 1,910 & 1,701 \\
\hline TOTAL (in - out) & 209 & \\
\hline
\end{tabular}

The mean monthly precipitation rate for November from site 7 is $1.4 \mathrm{~mm} /$ day. This equates to a daily average input of $411 \mathrm{~m}^{3} /$ day assuming a wetland area of $30 \mathrm{ha}$.

The mean monthly reference evapotranspiration rate for November calculated using the FAO Penman-Monteith equation is $3.7 \mathrm{~mm} /$ day. This equates to $1,110 \mathrm{~m}^{3} /$ day assuming a wetland area of 30ha. 


\begin{tabular}{|c|c|c|}
\hline & December - water balance \\
\hline Precipitation & 460 & Out $\left(\mathrm{m}^{3} /\right.$ day $)$ \\
& & -- \\
\hline Evapotranspiration & -- & 1,020 \\
\hline Surface water & $-1,814$ & 1,460 \\
\hline Groundwater & 1,716 & 222 \\
\hline Total & 362 & 2,702 \\
\hline TOTAL (in - out) & $-2,340$ & \\
\hline
\end{tabular}

The mean monthly precipitation rate for December from site 7 is $1.5 \mathrm{~mm} /$ day. This equates to a daily average input of $460 \mathrm{~m}^{3} /$ day assuming a wetland area of $30 \mathrm{ha}$.

The mean monthly reference evapotranspiration rate for December calculated using the FAO Penman-Monteith equation is $3.4 \mathrm{~mm} /$ day. This equates to $1,020 \mathrm{~m}^{3} /$ day assuming a wetland area of $30 \mathrm{ha}$. 


\section{Appendix 4}

Table 4 (a) Mean annual rainfall 1960 - 2006

\begin{tabular}{|c|c|c|c|c|c|}
\hline Year & $\begin{array}{c}\text { Mean } \\
\text { annual } \\
\text { rainfall }(\mathrm{mm})\end{array}$ & Year & $\begin{array}{c}\text { Mean } \\
\text { annual } \\
\text { rainfall }(\mathrm{mm})\end{array}$ & Year & $\begin{array}{c}\text { Mean } \\
\text { annual } \\
\text { rainfall }(\mathrm{mm})\end{array}$ \\
\hline 1960 & 867.8 & 1976 & 1074.8 & 1992 & 1019.9 \\
\hline 1961 & 816.2 & 1977 & 1135 & 1993 & 894.9 \\
\hline 1962 & 1310.2 & 1978 & 958.1 & 1994 & 956 \\
\hline 1963 & 804 & 1979 & 1343.2 & 1995 & 1179.4 \\
\hline 1964 & 1150.9 & 1980 & 1408.5 & 1996 & 1223.8 \\
\hline 1965 & 1013.5 & 1981 & 899.3 & 1997 & 855.9 \\
\hline 1966 & 1298.4 & 1982 & 995.3 & 1998 & 1218.4 \\
\hline 1967 & 1075.6 & 1983 & 1136.4 & 1999 & 867.7 \\
\hline 1968 & 1195.7 & 1984 & 916.2 & 2000 & 850.5 \\
\hline 1969 & 706.1 & 1985 & 1155.3 & 2001 & 1044.1 \\
\hline 1970 & 884.1 & 1986 & 1136.1 & 2002 & 1031.7 \\
\hline 1971 & 936.1 & 1987 & 894.3 & 2003 & 822.8 \\
\hline 1972 & 828.7 & 1988 & 846.6 & 2004 & 1445.4 \\
\hline 1973 & 827 & 1989 & 865 & 2005 & 752.6 \\
\hline 1974 & 1129 & 1990 & 1096 & 2006 & 1214 \\
\hline 1975 & 1224.2 & 1991 & 1045.2 & & \\
\hline Average & 1058 & Average & 1036 & Average & 1030.5 \\
\hline
\end{tabular}

* highlighted sections show below average rainfall.

Source: NIWA (2007) Pers Com 
Table 4 (b) Calculated rainfall for Te Harakiki 1960 - 2006

\begin{tabular}{|c|c|c|c|c|c|}
\hline Year & $\begin{array}{c}\text { Mean } \\
\text { rainfall } \\
\left(\mathrm{m}^{3} / \text { day }\right)\end{array}$ & Year & $\begin{array}{c}\text { Mean } \\
\text { rainfall } \\
\left(\mathrm{m}^{3} / \text { day }\right)\end{array}$ & Year & $\begin{array}{c}\text { Mean } \\
\text { rainfall } \\
\left(\mathrm{m}^{3} / \text { day }\right)\end{array}$ \\
\hline 1960 & 713.3 & 1976 & 883.4 & 1992 & 838.3 \\
\hline 1961 & 670.8 & 1977 & 932.9 & 1993 & 735.5 \\
\hline 1962 & 1076.9 & 1978 & 787.5 & 1994 & 785.7 \\
\hline 1963 & 660.8 & 1979 & 1104 & 1995 & 969.4 \\
\hline 1964 & 945.9 & 1980 & 1157.7 & 1996 & 1005.9 \\
\hline 1965 & 833.0 & 1981 & 739.2 & 1997 & 703.5 \\
\hline 1966 & 1067.2 & 1982 & 818.1 & 1998 & 1001.4 \\
\hline 1967 & 884.1 & 1983 & 934.0 & 1999 & 713.2 \\
\hline 1968 & 982.8 & 1984 & 753.0 & 2000 & 699.0 \\
\hline 1969 & 580.4 & 1985 & 949.6 & 2001 & 858.2 \\
\hline 1970 & 726.6 & 1986 & 933.8 & 2002 & 848.0 \\
\hline 1971 & 769.4 & 1987 & 735.0 & 2003 & 676.3 \\
\hline 1972 & 681.1 & 1988 & 695.8 & 2004 & 1188.0 \\
\hline 1973 & 679.7 & 1989 & 711.0 & 2005 & 618.6 \\
\hline 1974 & 927.9 & 1990 & 900.8 & 2006 & 997.8 \\
\hline 1975 & 1006.2 & 1991 & 859.1 & & \\
\hline
\end{tabular}

* highlighted sections show below average rainfall. 
Table 4 (c) - Mean annual Evapotranspiration 1960 -2006

\begin{tabular}{|c|c|c|c|c|c|}
\hline Year & $\begin{array}{c}\text { Mean annual } \\
\text { Evapotranspiration } \\
(\mathrm{mm})\end{array}$ & Year & $\begin{array}{c}\text { Mean annual } \\
\text { Evapotranspiration } \\
(\mathrm{mm})\end{array}$ & Year & $\begin{array}{c}\text { Mean annual } \\
\text { Evapotranspiration } \\
(\mathrm{mm})\end{array}$ \\
\hline 1960 & 738.9 & 1976 & 706.9 & 1992 & 674.2 \\
\hline 1961 & 755.4 & 1977 & 724 & 1993 & 713 \\
\hline 1962 & 802.2 & 1978 & 777.4 & 1994 & 725.8 \\
\hline 1963 & 743.4 & 1979 & 705.1 & 1995 & 749.1 \\
\hline 1964 & 728.1 & 1980 & 701.4 & 1996 & 729.8 \\
\hline 1965 & 721.6 & 1981 & 726 & 1997 & 718.7 \\
\hline 1966 & 709.2 & 1982 & 698.9 & 1998 & 760.5 \\
\hline 1967 & 724 & 1983 & 687.1 & 1999 & 787.3 \\
\hline 1968 & 750.7 & 1984 & 762.1 & 2000 & 755 \\
\hline 1969 & 753 & 1985 & 776.2 & 2001 & 731.1 \\
\hline 1970 & 749.2 & 1986 & 765.1 & 2002 & 753.3 \\
\hline 1971 & 773.6 & 1987 & 759.5 & 2003 & 775.5 \\
\hline 1972 & 703.2 & 1988 & 761.2 & 2004 & 715.5 \\
\hline 1973 & 760.5 & 1989 & 797.7 & 2005 & 785.5 \\
\hline 1974 & 800.7 & 1990 & 769.8 & 2006 & 738.9 \\
\hline 1975 & 749.3 & 1991 & 725.9 & & \\
\hline
\end{tabular}

* Highlighted section relate to years with below average rainfall (see table 4 (a)) Source NIWA (2007) Pers Com

Priestley - Taylor (1972) equation:

$$
\mathrm{ETpt}=\frac{\alpha}{\lambda} \frac{\Delta}{\Delta+\gamma}(\mathrm{Rn}-\mathrm{G})
$$

Source: Suleiman and Hoogenboom (2007) 
Table 4 (d) Calculated evapotranspiration rates for Te Harakiki 1960 - 2006

\begin{tabular}{|c|c|c|c|c|c|}
\hline Year & $\begin{array}{c}\text { Mean } \\
\text { Evapotranspiration } \\
\left(\mathrm{m}^{3} / \text { day }\right)\end{array}$ & Year & $\begin{array}{c}\text { Mean } \\
\text { Evapotranspiration } \\
\left(\mathrm{m}^{3} / \text { day }\right)\end{array}$ & Year & $\begin{array}{c}\text { Mean } \\
\text { Evapotranspiration } \\
\left(\mathrm{m}^{3} / \text { day }\right)\end{array}$ \\
\hline 1960 & 607.3 & 1976 & 581.0 & 1992 & 554.1 \\
\hline 1961 & 620.9 & 1977 & 595.1 & 1993 & 586.0 \\
\hline 1962 & 659.3 & 1978 & 639.0 & 1994 & 596.5 \\
\hline 1963 & 611.0 & 1979 & 579.5 & 1995 & 615.7 \\
\hline 1964 & 598.4 & 1980 & 576.5 & 1996 & 599.8 \\
\hline 1965 & 593.1 & 1981 & 596.7 & 1997 & 590.7 \\
\hline 1966 & 582.9 & 1982 & 574.4 & 1998 & 625.1 \\
\hline 1967 & 595.1 & 1983 & 564.7 & 1999 & 647.1 \\
\hline 1968 & 617.0 & 1984 & 626.4 & 2000 & 620.5 \\
\hline 1969 & 618.9 & 1985 & 638.0 & 2001 & 600.9 \\
\hline 1970 & 615.8 & 1986 & 628.8 & 2002 & 619.2 \\
\hline 1971 & 635.8 & 1987 & 624.2 & 2003 & 637.4 \\
\hline 1972 & 578.0 & 1988 & 625.6 & 2004 & 588.1 \\
\hline 1973 & 625.1 & 1989 & 655.6 & 2005 & 645.6 \\
\hline 1974 & 658.1 & 1990 & 632.7 & 2006 & 607.3 \\
\hline 1975 & 615.9 & 1991 & 596.6 & & \\
\hline
\end{tabular}

* Highlighted sections relate to drier than normal rainfall years Tables 4 (a) and (b). 
Table 4 (e) Calculated precipitation rates - calculated evapotranspiration rates for Te Harakiki 1960 - 2006

\begin{tabular}{|c|c|c|c|c|c|}
\hline Year & $\begin{array}{c}\text { Precipitation - } \\
\text { Evapotranspiration } \\
\left(\mathrm{m}^{3} / \mathrm{day}\right)\end{array}$ & Year & $\begin{array}{c}\text { Precipitation - } \\
\text { Evapotranspiration } \\
\left(\mathrm{m}^{3} / \mathrm{day}\right)\end{array}$ & Year & $\begin{array}{c}\text { Precipitation - } \\
\text { Evapotranspiration } \\
\left(\mathrm{m}^{3} / \text { day }\right)\end{array}$ \\
\hline 1960 & 260.5 & 1976 & 493.8 & 1992 & 465.8 \\
\hline 1961 & 195.3 & 1977 & 539.9 & 1993 & 308.9 \\
\hline 1962 & 650.9 & 1978 & 319.1 & 1994 & 359.5 \\
\hline 1963 & 193 & 1979 & 763.7 & 1995 & 563.7 \\
\hline 1964 & 552.5 & 1980 & 832 & 1996 & 624 \\
\hline 1965 & 420.4 & 1981 & 302.6 & 1997 & 265.2 \\
\hline 1966 & 715.5 & 1982 & 420.9 & 1998 & 593.3 \\
\hline 1967 & 480.5 & 1983 & 571.7 & 1999 & 220.6 \\
\hline 1968 & 578.7 & 1984 & 289.8 & 2000 & 230 \\
\hline 1969 & 87.2 & 1985 & 517.3 & 2001 & 443.2 \\
\hline 1970 & 268.3 & 1986 & 507.3 & 2002 & 412.5 \\
\hline 1971 & 300.3 & 1987 & 270.1 & 2003 & 185.4 \\
\hline 1972 & 250.7 & 1988 & 221 & 2004 & 857.3 \\
\hline 1973 & 201.9 & 1989 & 209.4 & 2005 & 107 \\
\hline 1974 & 470.9 & 1990 & 463.3 & 2006 & 606.7 \\
\hline 1975 & 608.3 & 1991 & 448.6 & & \\
\hline
\end{tabular}




\section{Appendix 5}

\section{Rating Curves}
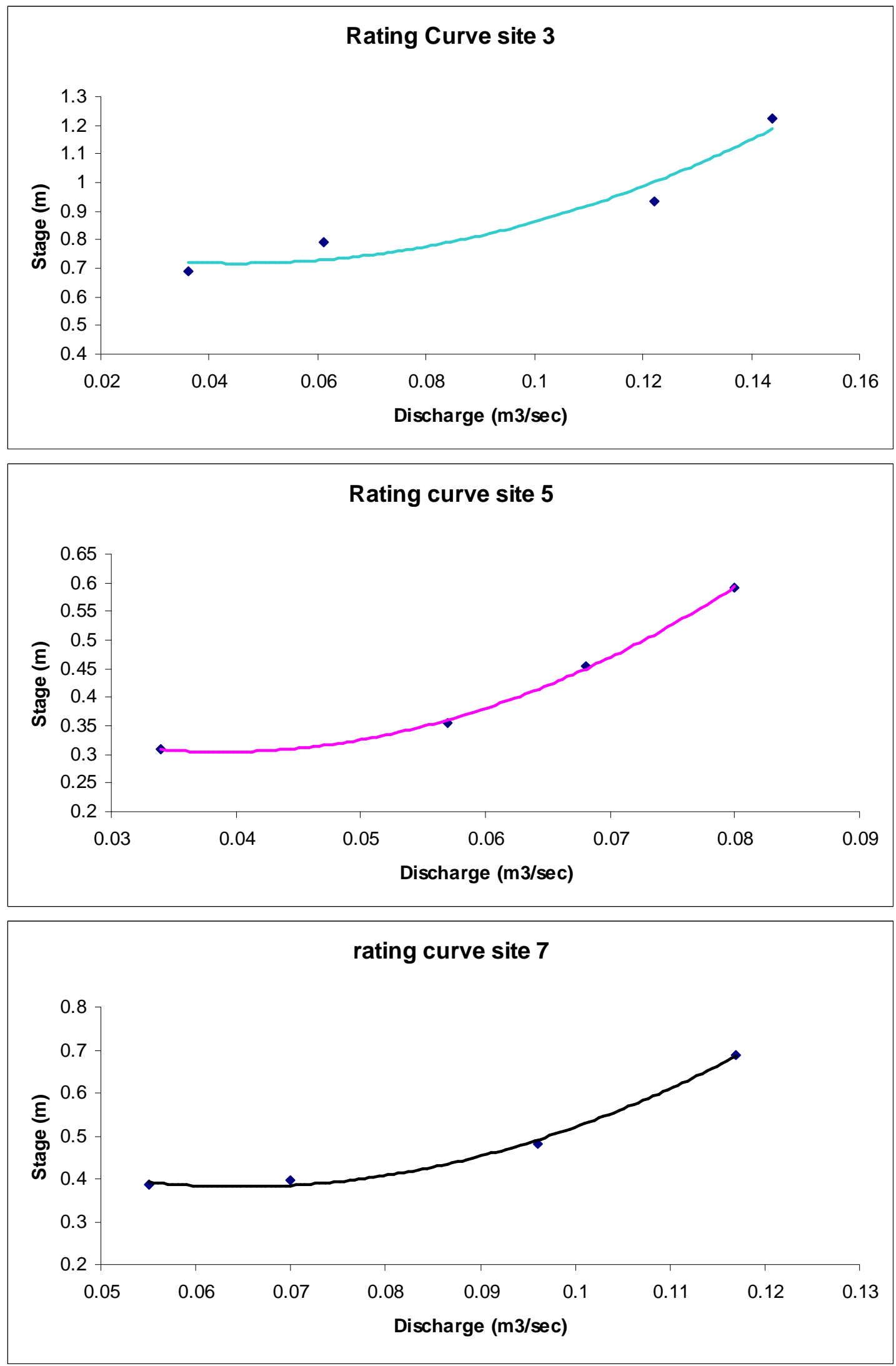
Appendix 6

Location of shallow groundwater bores

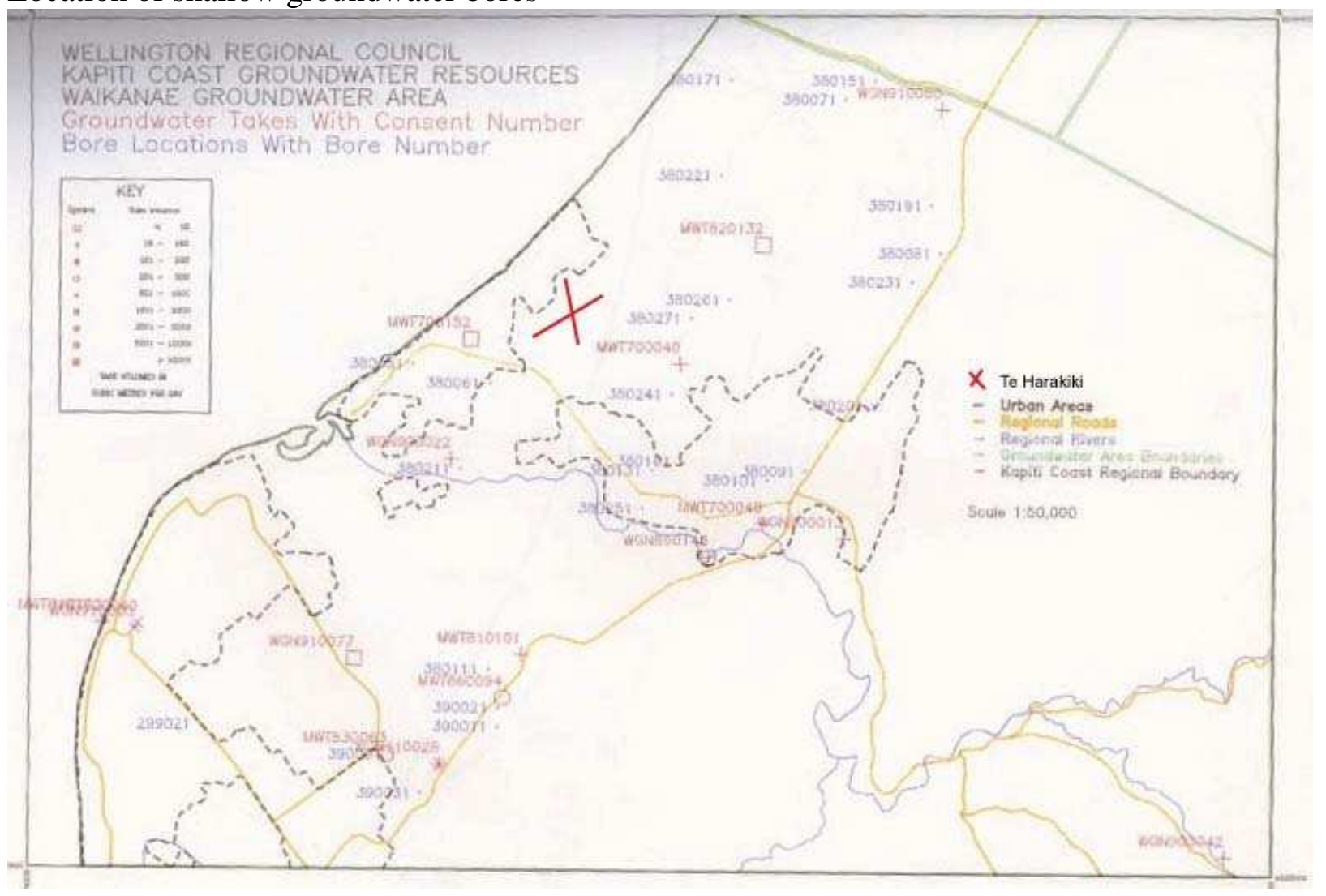

136 